Prepared in cooperation with the Muskingum Watershed Conservancy District

\title{
Baseline Water Quality of an Area Undergoing Shale- Gas Development in the Muskingum River Watershed, Ohio, 2015-16
}

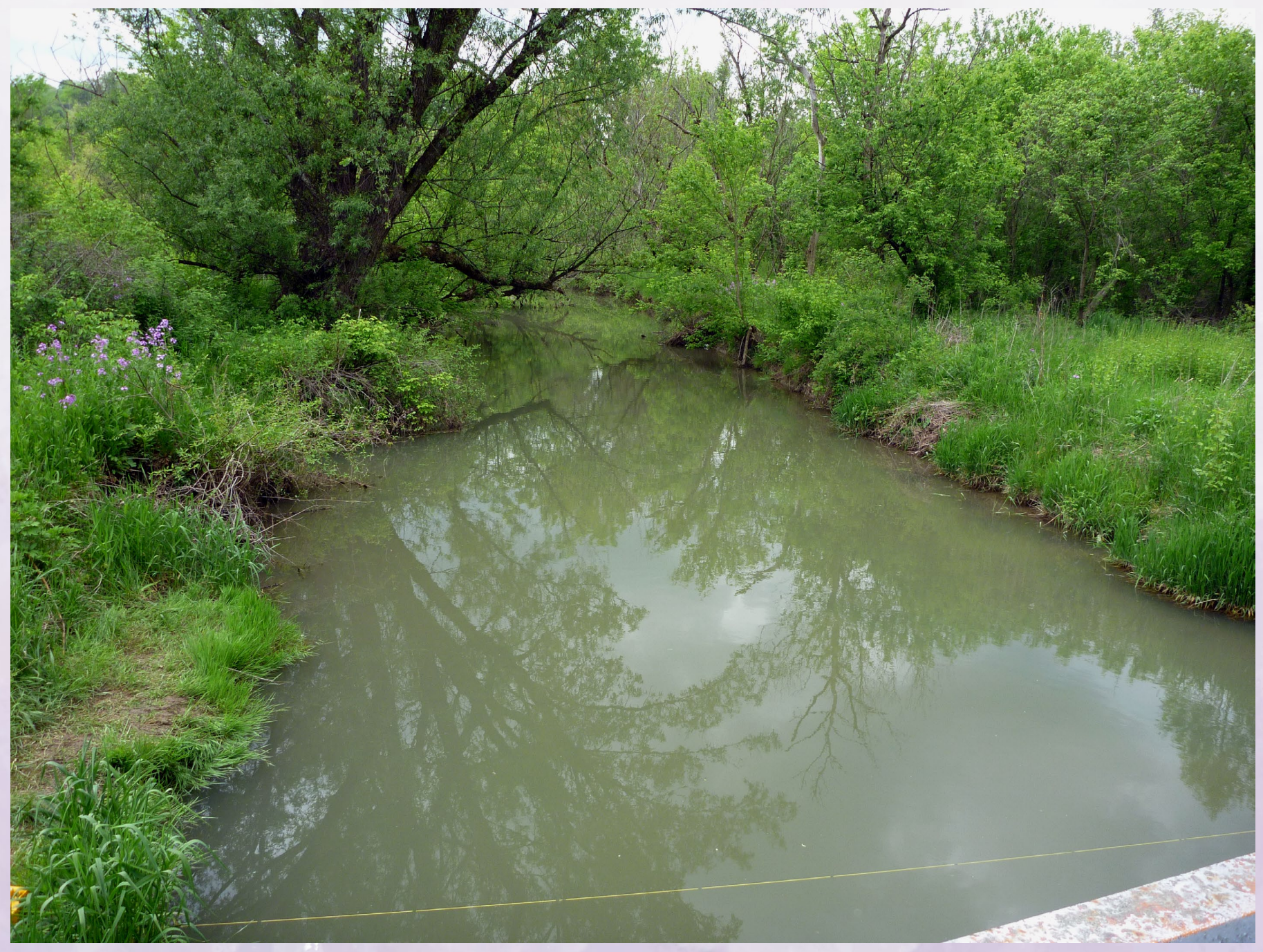

Scientific Investigations Report 2018-5113

U.S. Department of the Interior

U.S. Geological Survey 
Cover. Standingstone Fork above Tappan Lake, Ohio (USGS Station Number: 03127986) Photo credit: Carrie Huitger 


\section{Baseline Water Quality of an Area Undergoing Shale-Gas Development in the Muskingum River Watershed, Ohio, 2015-16}

By S. Alex. Covert, Martha L. Jagucki, and Carrie Huitger

Prepared in cooperation with the Muskingum Watershed Conservancy District

Scientific Investigations Report 2018-5113 


\title{
U.S. Department of the Interior \\ RYAN K. ZINKE, Secretary
}

\author{
U.S. Geological Survey \\ James F. Reilly II, Director
}

U.S. Geological Survey, Reston, Virginia: 2018

For more information on the USGS - the Federal source for science about the Earth, its natural and living resources, natural hazards, and the environment-visit https://www.usgs.gov or call 1-888-ASK-USGS.

For an overview of USGS information products, including maps, imagery, and publications,

visit https://store.usgs.gov.

Any use of trade, firm, or product names is for descriptive purposes only and does not imply endorsement by the U.S. Government.

Although this information product, for the most part, is in the public domain, it also may contain copyrighted materials as noted in the text. Permission to reproduce copyrighted items must be secured from the copyright owner.

Suggested citation:

Covert, S.A., Jagucki, M.L., and Huitger, C., 2018, Baseline water quality of an area undergoing shale-gas development in the Muskingum River watershed, Ohio, 2015-16: U.S. Geological Survey Scientific Investigations Report 2018-5113, 129 p., https://doi.org/10.3133/sir20185113.

ISSN 2328-0328 (online) 


\section{Acknowledgments}

The participation of landowners who made their streams accessible for the study is appreciated. 



\section{Contents}

Acknowledgments ……...................................................................................................................

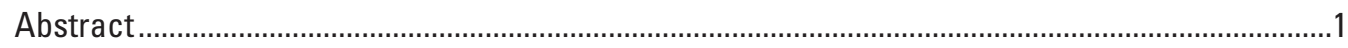

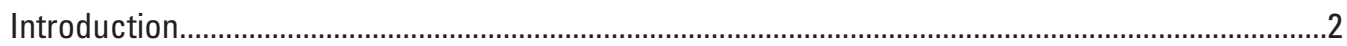

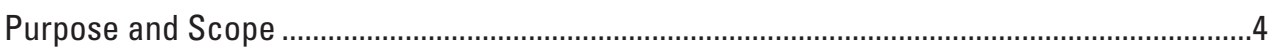

Description of Study Area and Existing Monitoring Network ..........................................................

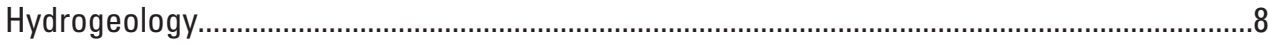

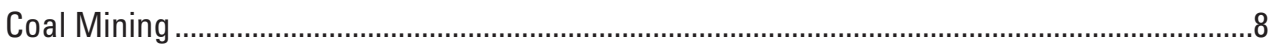

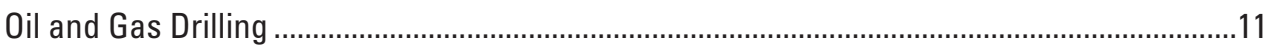

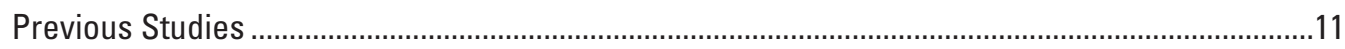

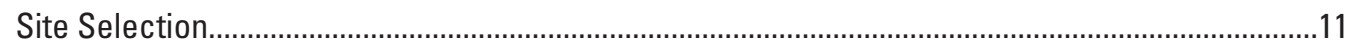

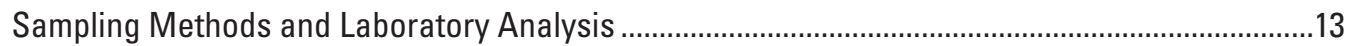

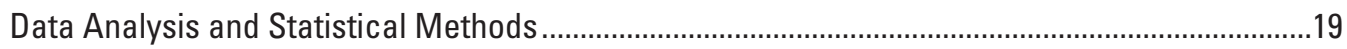

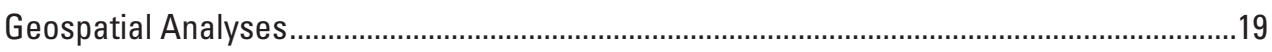

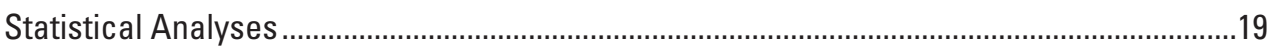

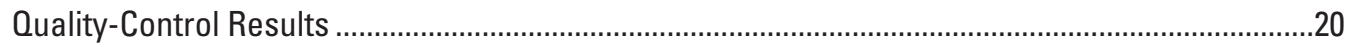

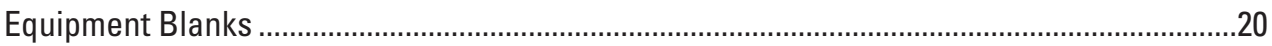

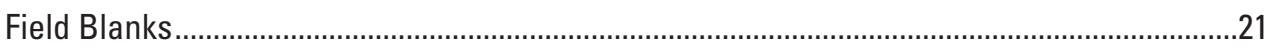

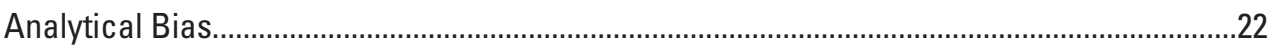

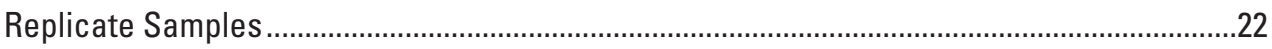

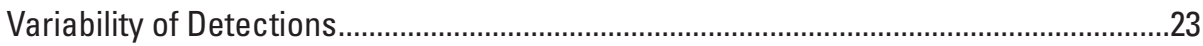

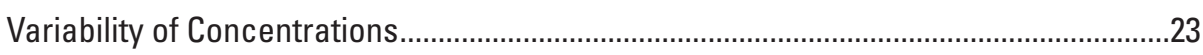

Data Treatment Based on Quality-Control Results.............................................................26

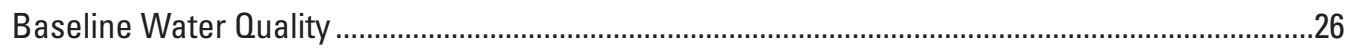

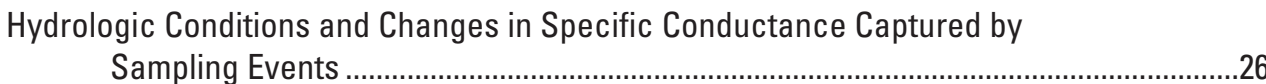

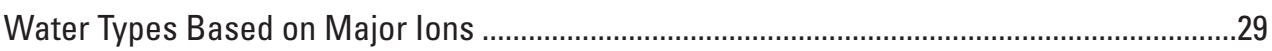

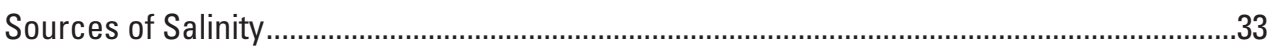

Concentrations or Levels of Selected Constituents and Properties ........................................38

$\mathrm{pH}$

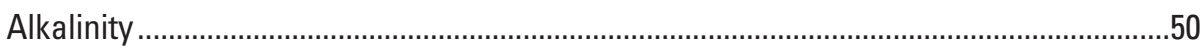

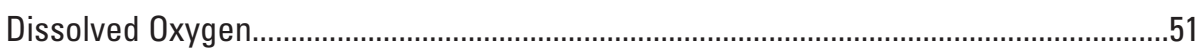

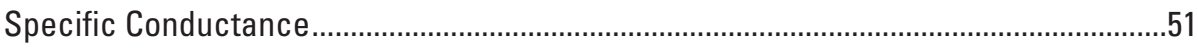

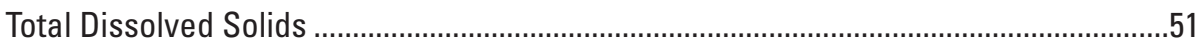

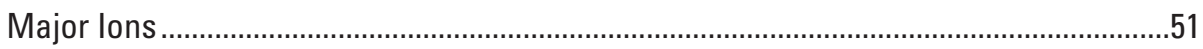

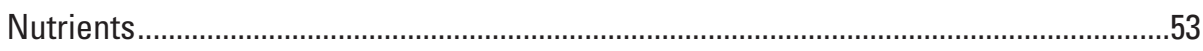

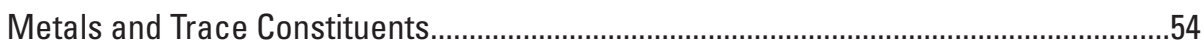

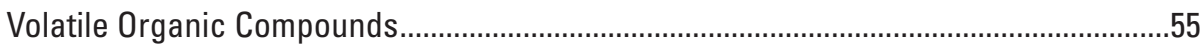

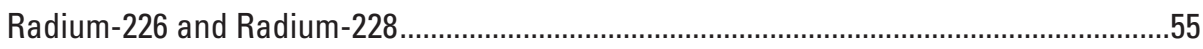

Relation Between Water Chemistry and Drainage Basin Characteristics .............................55

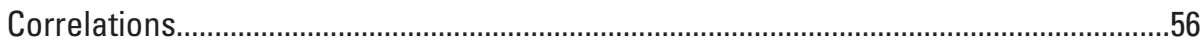

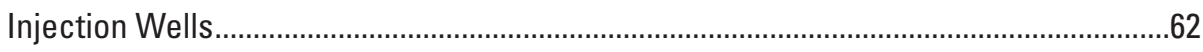

Comparison of Current (2015-16) to Historical Chloride Concentrations .................................62

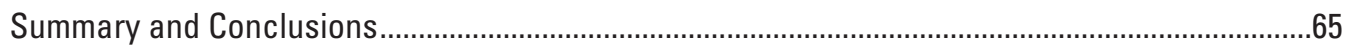

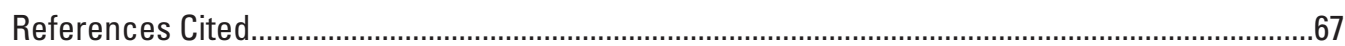


Appendix 1. Six Discrete Values of Stream Stage and Specific Conductance at Each Site were Compared to Hourly Measurements of Stream Stage and Specific Conductance at Each of the 14 Water-Quality Gages.

Appendix 2. Boxplots of Concentrations or Levels of Constituents and Properties ....................81

Appendix 3. Detections of Volatile Organic Compounds in Muskingum River Watershed, Ohio, 2015-16.

\section{Figures}

1. Map showing study area consisting of 6 lake drainage basins and 30 sampling sites within the Muskingum River watershed, Ohio, 2015-16.

2. Graph showing historical reported crude oil and gas production in Ohio, 2005-15 ........4

3. Map showing density of conventional and horizontal oil and gas wells and waste injection wells in Muskingum River watershed, Ohio, June 2016.

4. Map showing land covers within and around the study area, Muskingum River watershed, Ohio, 2015-16.

5. Map showing bedrock geology in study area, Muskingum River watershed, Ohio, 2015-16

6. Map showing lands associated with or affected by coal mines in the study area, Muskingum River watershed, Ohio, 2015-16.

7. Hydrographs of U.S. Geological Survey gaging stations $A, 03121850$ Huff Run at Mineral City, Ohio, and B, 03141870 Leatherwood Creek near Kipling, Ohio, April 1 through June 15, 2015

8. Trilinear diagram showing major cation and anion percentages for 30 water-quality samples collected in Muskingum River watershed, Ohio, 2015-16.

9. Graph showing median sulfate-to-chloride ratios for mine-impacted and non-mineimpacted sites in the Muskingum River watershed, Ohio, 2015-16.

10. Graph showing binary mixing curves for chloride-to-bromide ratios in the Muskingum River watershed, Ohio, 2015-16

11. Graphs showing concentrations or levels of constituents and properties that differed at a statistically significant level $(p$-value $<0.05)$ between mine-impacted and non-mine-impacted sites, Muskingum watershed, Ohio, April 2015 through May 2016

12. Graphs showing concentrations of constituents that differed at a statistically significant level ( $p$-value $<0.05$ ) for samples with and without a component of brine, Muskingum River watershed, Ohio, April 2015 through May 2016

13. Graphs showing specific conductance as a function of anion concentration, Muskingum River watershed, Ohio, 2015-16.

14. Graphs showing constituent concentrations that differed at a statistically significant level ( $p$-value $<0.05$ ) between sites with and without injection wells in their drainage areas (stream sites only), Muskingum River watershed, Ohio, 2015-16

15. Scatterplot of streamflow versus chloride concentrations with regression lines fit to data for each period (1960s, 1970s, 1980s, and 2015-16) at or near McGuire Creek near Leesville, Ohio, downstream from the dam at Leesville Lake.

16. Boxplots of chloride concentrations at Atwood, Leesville, Piedmont, Senecaville, and Tappan Lakes for each period (1960s, 1970s, 1980s, and 2015-16). 


\section{Tables}

1. Monthly and annual total precipitation, in inches, during the study period compared to long-term average annual precipitation at climate station USC00331197 in Cambridge, Ohio.

2. Major land cover in six lake drainage basins, Muskingum River watershed, Ohio, 2011 .....

3. Site information for 30 sites in baseline water-quality study in Muskingum River watershed, Ohio, 2015-16

4. Constituents and properties, reporting levels, and analytical methods for baseline water-quality study in Muskingum River watershed, Ohio, 2015-16.

5. Water-quality sample-collection sites where discharge at the time of sample collection was estimated using a measurement made on a later date, April-June 2015

6. Geospatial data types, sources, and transformations used for analyses in baseline water-quality study in Muskingum River watershed, 0hio, 2015-16

7. Variability of detections in field replicates for baseline water-quality study in Muskingum River watershed, Ohio, 2015-16....

8. Minimum, median, and maximum concentrations or levels of constituents and properties in streams, lakes, and gage sites downstream from the dams in the Muskingum River watershed, Ohio, 2015-16

9. Percentage of specific conductance and stream stage variation measured by 6 discrete stream samples at 14 sites compared to continuous measurements, Muskingum River watershed, Ohio, April 1, 2015, through June 30, 2016.

10. Chemical water-quality criteria for mine drainage impacts.

11. List of mine-impacted sites per lake drainage basin for baseline water-quality study in Muskingum River watershed, Ohio, 2015-16

12. Environmental and human-based drainage basin characteristics compiled by upstream drainage basin for 30 sites in Muskingum River watershed, Ohio, July 2016

13. Constituents and properties indicating a relation between measured value and streamflow at most sites in the study area, Muskingum River watershed, Ohio, 2015-16

14. Ohio Environmental Protection Agency aquatic life use criteria and exceedances for baseline water-quality study in Muskingum River watershed, Ohio, 2015-16 ...........42

15. Redox environment classification for sites downstream from dams, Muskingum River watershed, 2015-16.

16. Spearman's rank correlation coefficients between median concentrations or levels of constituents and drainage basin characteristics for non-mine-impacted stream sites in Muskingum River watershed, Ohio, 2015-16

17. Spearman's rank correlation coefficients between median concentrations or levels of constituents and drainage basin characteristics for mine-impacted stream sites in Muskingum River watershed, Ohio, 2015-16..

18. Spearman's rank correlation coefficients between drainage basin characteristics for non-mine-impacted $(A)$ and mine-impacted $(B)$ stream sites in Muskingum River watershed, Ohio, 2015-16.

19. Wilcoxon rank sum test Z-values and $p$-values between median concentrations of selected constituents at sites with and without injection wells in their drainage areas, Muskingum River watershed, Ohio, 2015-16 


\section{Conversion Factors}

U.S. customary units to International System of Units

\begin{tabular}{lcl}
\hline \multicolumn{1}{c}{ Multiply } & By & \multicolumn{1}{c}{ To obtain } \\
\hline inch (in.) & Length & \\
foot (ft) & 2.54 & centimeter $(\mathrm{cm})$ \\
mile (mi) & 0.3048 & meter $(\mathrm{m})$ \\
\hline \multicolumn{3}{c}{ kilometer $(\mathrm{km})$} \\
\hline square mile $\left(\mathrm{mi}^{2}\right)$ & 1.609 & \\
\hline & Area & square kilometer $\left(\mathrm{km}^{2}\right)$ \\
\hline barrel $(\mathrm{bbl}$; petroleum, 1 barrel=42 gal) & 2.590 & \\
\hline & Volume & \\
\hline cubic foot per second $\left(\mathrm{ft}{ }^{3} / \mathrm{s}\right)$ & 0.1590 & cubic meter $\left(\mathrm{m}^{3}\right)$ \\
\hline & 0.02832 & cubic meter per second $\left(\mathrm{m}^{3} / \mathrm{s}\right)$ \\
\hline picocurie per liter $(\mathrm{pCi} / \mathrm{L})$ & Radioactivity & \\
\hline
\end{tabular}

Temperature in degrees Fahrenheit $\left({ }^{\circ} \mathrm{F}\right)$ may be converted to degrees Celsius $\left({ }^{\circ} \mathrm{C}\right)$ as follows:

$$
{ }^{\circ} \mathrm{C}=\left({ }^{\circ} \mathrm{F}-32\right) / 1.8 .
$$

International System of Units to U.S. customary units

\begin{tabular}{|c|c|c|}
\hline Multiply & By & To obtain \\
\hline \multicolumn{3}{|c|}{ Length } \\
\hline centimeter $(\mathrm{cm})$ & 0.3937 & inch (in.) \\
\hline meter $(\mathrm{m})$ & 3.281 & foot $(\mathrm{ft})$ \\
\hline kilometer $(\mathrm{km})$ & 0.6214 & mile (mi) \\
\hline \multicolumn{3}{|c|}{ Area } \\
\hline square kilometer $\left(\mathrm{km}^{2}\right)$ & 0.3861 & square mile $\left(\mathrm{mi}^{2}\right)$ \\
\hline \multicolumn{3}{|c|}{ Volume } \\
\hline cubic meter $\left(\mathrm{m}^{3}\right)$ & 6.290 & barrel (bbl; petroleum, 1 barrel = 42 gal) \\
\hline \multicolumn{3}{|c|}{ Flow rate } \\
\hline cubic meter per second $\left(\mathrm{m}^{3} / \mathrm{s}\right)$ & 35.31 & cubic foot per second $\left(\mathrm{ft}^{3} / \mathrm{s}\right)$ \\
\hline \multicolumn{3}{|c|}{ Radioactivity } \\
\hline becquerel per liter $(\mathrm{Bq} / \mathrm{L})$ & 27.027 & picocurie per liter (pCi/L) \\
\hline
\end{tabular}

Temperature in degrees Celsius $\left({ }^{\circ} \mathrm{C}\right)$ may be converted to degrees Fahrenheit $\left({ }^{\circ} \mathrm{F}\right)$ as follows:

$$
{ }^{\circ} \mathrm{F}=\left(1.8 \times{ }^{\circ} \mathrm{C}\right)+32 .
$$

\section{Datum}

Vertical coordinate information is referenced to the North American Vertical Datum of 1988 (NAVD 88).

Horizontal coordinate information is referenced to the North American Datum of 1983 (NAD 83). 


\section{Supplemental Information}

Specific conductance is reported in microsiemens per centimeter at 25 degrees Celsius $\left(\mu \mathrm{S} / \mathrm{cm}\right.$ at $\left.25^{\circ} \mathrm{C}\right)$.

Concentrations of chemical constituents in water are reported in either milligrams per liter (mg/L) or micrograms per liter ( $\mu \mathrm{g} / \mathrm{L})$.

Activities for radioactive constituents in water are reported in picocuries per liter (pCi/L).

\section{Abbreviations and Acronyms}

$\begin{array}{ll}\text { BTEX } & \text { benzene, toluene, ethylbenzene, and xylene } \\ \text { Cl:Br } & \text { chloride-to-bromide } \\ \text { GIS } & \text { geographic information system } \\ \text { mg/L } & \text { milligram per liter } \\ \text { MWCD } & \text { Muskingum Watershed Conservancy District } \\ \text { NTU } & \text { nephelometric turbidity unit } \\ \text { NTRU } & \text { nephelometric turbidity ratio unit } \\ \text { NWIS } & \text { National Water Information System } \\ \text { NWOL } & \text { National Water Quality Laboratory } \\ \text { ODNR-DMRM } & \text { Ohio Department of Natural Resources, Division of Mineral Resources } \\ \text { OEPA } & \text { Management } \\ \text { OMZA } & \text { Ohio Environmental Protection Agency } \\ \text { OMZM } & \text { outside mixing zone average } \\ \text { OC } & \text { outside mixing zone maximum } \\ \text { OSB } & \text { quality-control } \\ R^{2} & \text { Ouality Systems Branch } \\ \text { RPD } & \text { coefficient of determination } \\ \text { SAS } & \text { relative percent difference } \\ \text { TPCN } & \text { Statistical Analysis System } \\ \mu \text { th/L } & \text { total particulate carbon and nitrogen } \\ \mu m & \text { microgram per liter } \\ \text { USACE } & \text { micrometer } \\ \text { USGS } & \text { U.S. Army Corps of Engineers } \\ \text { VOC } & \text { U.S. Geological Survey } \\ \text { volatile organic compound } \\ \end{array}$





\title{
Baseline Water Quality of an Area Undergoing Shale-Gas Development in the Muskingum River Watershed, Ohio, 2015-16
}

\author{
By S. Alex. Covert, Martha L. Jagucki, and Carrie Huitger
}

\section{Abstract}

In 2015-16, the U.S. Geological Survey, in cooperation with the Muskingum Watershed Conservancy District, led a study to assess baseline (2015-16) surface-water quality in six lake drainage basins within the Muskingum River watershed that are in the early years of shale-gas development. In 2015, 9 of the 10 most active counties in Ohio for oil and gas development were wholly or partially within the Muskingum River watershed. In addition to shale gas development, the area has a history of conventional oil and gas development and coal mining.

In all, 30 surface-water sites were sampled: 20 in tributaries flowing to the lakes, 4 in lakes themselves, and 6 downstream of the lakes. At each of the 30 sites, 6 samples were collected to characterize surface-water chemistry throughout a range of hydrologic conditions. The sampling generally occurred during low flows (periods of greater groundwater contribution) rather than during runoff events (periods of high stream stage).

Trilinear diagrams of major ion chemistry revealed three main types of water in the study area-sulfate-dominated waters, bicarbonate-dominated waters, and waters with mixed bicarbonate and chloride anions. Most sites produced samples of bicarbonate-dominated water, and 11 sites produced samples with sulfate-type waters. Mixed bicarbonate and chloride waters were found in samples from two of the six lake drainage basins studied.

The baseline (2015-16) assessment of surface-water quality in the study area indicated that few water-chemistry constituents and properties occurred at concentrations or levels that would adversely affect aquatic organisms. Chemicalspecific, aquatic life use criteria were not met in only three instances: two were for total dissolved solids at sites likely impacted by coal mining in their drainage basins (hereafter referred to as "mine-impacted sites"), and one was for dissolved oxygen.

Mine drainage from historical coal mining in the region likely affected the quality of about one-third of the streams sampled. To simplify interpretation of water-chemistry results, 11 sites with sulfate-type water were identified as mine-impacted sites based on water-quality criteria established by Ohio Department of Natural Resources, Division of Mineral Resources Management, and separated out for subsequent statistical analysis. Concentrations or levels of bicarbonate, boron, calcium, carbonate, total dissolved solids, fluoride, magnesium, lithium, $\mathrm{pH}$, potassium, sodium, specific conductance, strontium, sulfate, and suspended sediment in water were higher (significance level of 0.05) at mine-impacted stream sites than at non-mine-impacted stream sites.

An accidental release of oil- and gas-related brines could increase salinity (sodium and chloride), the concentration of total dissolved solids in shallow groundwater and streams, and specific conductance. For this study, chloride concentrations in the study area ranged from 2.12 to 76.1 milligrams per liter. Sources of chloride in water samples were evaluated using binary mixing curves and ratios of chloride to bromide. These ratios indicated that 13 samples from 3 sites in the drainage basin that contained the highest density of conventional oil and gas wells in the study, as well as 4 samples collected from other drainage basins, likely contained a component of brine. Concentrations or levels of barium, bromide, chloride, iron, lithium, manganese, and sodium were significantly higher $($ alpha $=0.05)$ in samples with a component of brine than in samples without a component of brine.

Benzene, toluene, ethylbenzene and xylene (BTEX), compounds that occur naturally in crude oil, made up 24 of the 45 detections ( 53 percent) of volatile organic compounds in the study area. The BTEX detections were not associated with sites containing a component of brine. The only volatile organic compound detected in any of the 17 samples that contained a component of brine was acetone, detected in 3 (18 percent) of these samples and in 11 percent of samples not containing a component of brine. Considering that BTEX are gasoline hydrocarbons and that most of the detections occurred during warmer months in and around the lakes, the BTEX detections likely are associated with increases in outdoor activities such as automobile and boating traffic.

Radium-226 and radium-228 were included in the list of analytes for this study because production water from shale-gas drilling can contain these naturally occurring radioactive materials. Concentrations of radium-226 exceeded 
background levels in only two surface-water samples. Concentrations of radium-228 exceeded background levels in one surface-water sample.

A brine signature potentially indicative of oil and gas contamination was detected in samples collected at two sites that contained active or plugged waste injection wells, or both. Results from the study indicated significant differences in the median concentrations of bromide, chloride, lithium, manganese, sodium, and total dissolved nitrogen between sites with and without injection wells in their drainage areas. Median concentrations of bromide, chloride, lithium, and sodium, which are common oil- and gas-related contaminants, were higher at sites with injection wells in their drainage areas compared to sites without injection wells.

Historical (1960s, 1970s, and 1980s) chloride concentrations and streamflow data at or near five of the six sampling sites downstream from each lake dam were compared to current (2015-16) values. An analysis of covariance was done to test the effects of streamflow, time (decade), and the combined effects (cross product) of streamflow and time on chloride concentrations. Those analyses indicated that streamflow was not significant in explaining the variation in chloride concentration, likely because streamflow in those locations is controlled by dam operations; therefore, association between runoff-generating events and streamflow is less direct than in unregulated streams. From the 1980 s to the study period (2015-16), data for three of the five lakes indicated an increase in chloride concentrations. The comparison of historical and current (2015-16) study data from samples collected at another lake indicated that chloride concentrations increased from the 1960s to the 1970s, but concentrations in the 1970s and 2015-16 were similar even though 13 samples from this lake drainage basin were classified as having a component of brine. Median chloride concentrations for the fifth lake, however, seemed to decrease from the 1980 s to 2015-16.

\section{Introduction}

The Muskingum River watershed, the largest watershed completely contained within Ohio (fig. 1), covers more than 8,000 square miles (approximately one-fifth of the State) and all or part of 27 counties (Muskingum Watershed Conservancy District [MWCD], 2017a). The Muskingum Watershed Conservancy District is tasked with providing flood reduction, water conservation, and recreational opportunities within the watershed. To accomplish these goals, the MWCD works with the U.S. Army Corps of Engineers (USACE) to manage 10 permanent dams and reservoirs, hereafter referred to as "lakes," in the watershed - the USACE operates the dams for flood reduction and the MWCD manages most of the lake areas upstream from the dams. The lakes are popular recreation areas in the Muskingum River watershed (MWCD, 2017b). The study area included 6 of the 10 lakes (fig. 1).
In 2015, 9 of the 10 most active counties in Ohio regarding oil and gas development (Belmont, Carroll, Columbiana, Guernsey, Harrison, Monroe, Noble, Stark, and Tuscarawas Counties - not shown) were wholly or partially within the Muskingum River watershed (Ohio Department of Natural Resources [ODNR], Division of Oil \& Gas Resources, 2017a) along the eastern edge of the watershed. In 2015, the wells in those nine counties produced about 90 percent of the crude oil and 95 percent of the natural gas in the State. Crude oil production in Ohio increased more than 500 percent from 2012 to 2015, and natural gas production increased elevenfold (fig. 2) (ODNR, Division of Oil \& Gas Resources, 2015; ODNR, Division of Oil \& Gas Resources, 2017b). Most of the increase in production can be attributed to an increase in horizontal drilling to recover oil and gas from shales. In 2012, production from the Utica Shale and the Point Pleasant Limestone, referred to hereafter as the Utica/Point Pleasant formation, and the Marcellus Shale in the State accounted for 12.8 percent of oil production and 14.8 percent of natural gas production (ODNR, Division of Oil \& Gas Resources Management, 2013); by 2014, shale formations accounted for 73 percent of oil production and 88.3 percent of natural gas production. Of all wells drilled in Ohio in 2014, 73 percent targeted the Utica/Point Pleasant formation (ODNR, Division of Oil \& Gas Resources, 2015).

As shale-gas production expanded in Ohio and elsewhere in the United States, public concern increased about the potential effects of energy development on water quality (U.S. Department of Energy, 2013). Oil and gas production can lead to increased sediment runoff to nearby surface waters through activities at the drill site such as road and well-pad construction (Entrekin and others, 2011). Likewise, the construction of pipeline infrastructure can cause significant land disturbances and increased sediment runoff (Entrekin and others, 2011). Once a well is drilled, water, sand, and chemical additives are injected into the shale under high pressure to fracture the shale and release the gas. About 20 percent of this mixture flows back to the surface through the well bore within days of being injected (Ohio Environmental Protection Agency [OEPA], 2014). This "flowback" water is stored temporarily in tanks or engineered impoundments before being sent offsite for disposal or reuse. Flowback water often contains volatile organic compounds (VOCs) such as benzene, toluene, ethylbenzene, and xylene (BTEX) and other organic compounds (Guerra and others, 2011). Flowback water and brines that are naturally present in the shale are coproduced with the oil and gas throughout the lifetime of the well and are referred to as "production water." Production water contains elevated concentrations of major ions and trace elements leached from the shale formation, including calcium, magnesium, sodium, bicarbonate, sulfate, chloride, bromide, barium, iron, and strontium, compared to natural surface waters.

Production water often can be classified as brine, with a chloride concentration of 100,000 milligrams per liter $(\mathrm{mg} / \mathrm{L})$ or higher. Production water can also contain naturally occurring radioactive materials, such as radium isotopes. (The radium 

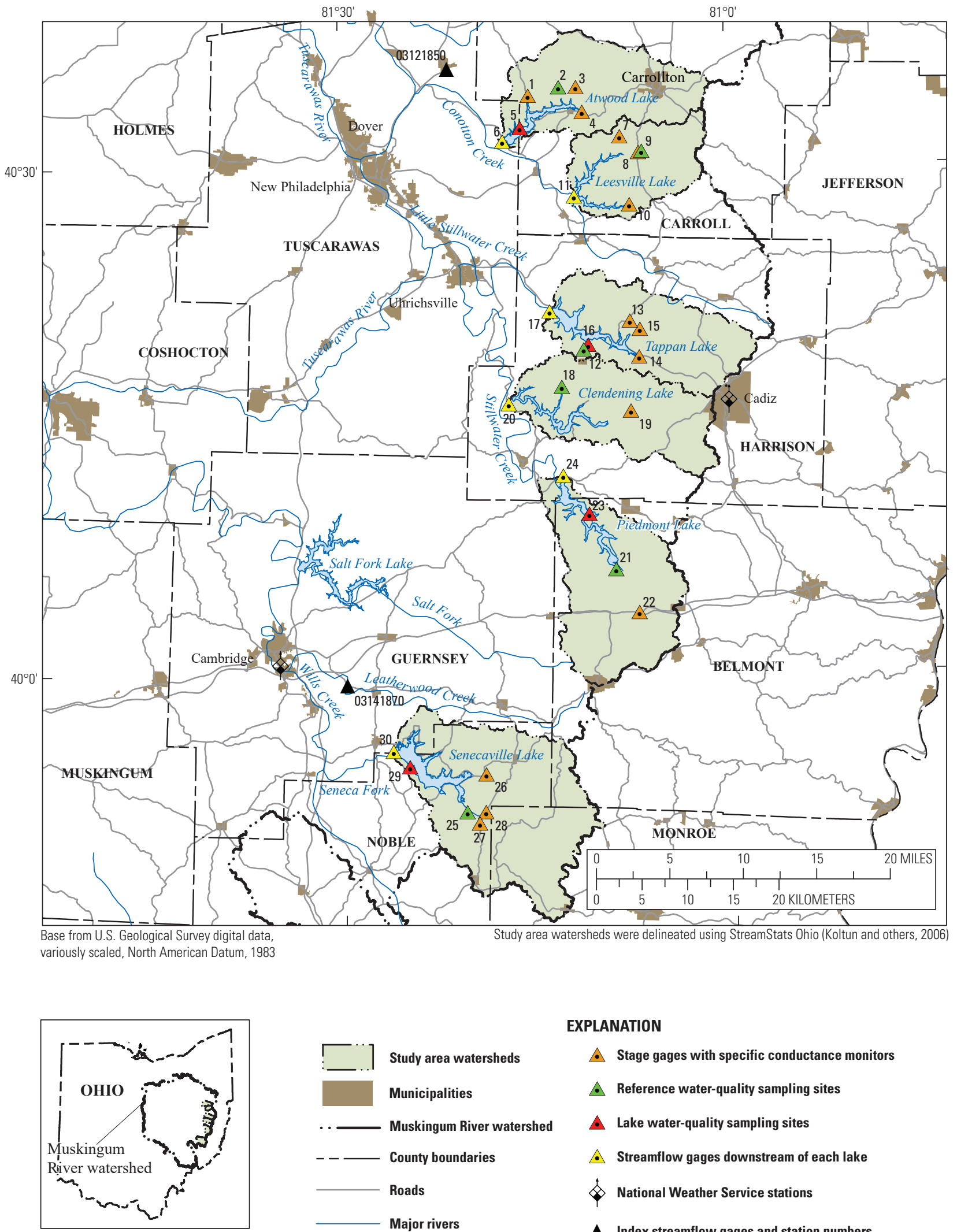

EXPLANATION

- Stage gages with specific conductance monitors

- Reference water-quality sampling sites

A Lake water-quality sampling sites

- Streamflow gages downstream of each lake

National Weather Service stations

A Index streamflow gages and station numbers

Figure 1. Study area consisting of 6 lake drainage basins and 30 sampling sites within the Muskingum River watershed, Ohio, 2015-16. 


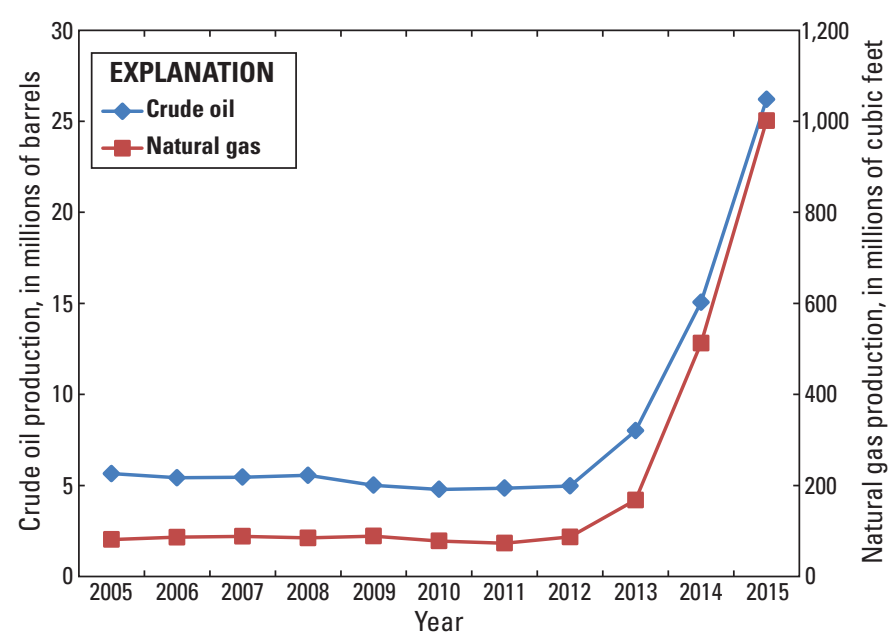

Figure 2. Historical reported crude oil and gas production in Ohio, 2005-15.

isotopic ratio, radium-228-to-radium-226, in water samples has been suggested as an indicator of the provenance or source of radium in samples of unknown origin. The radium-228-toradium-226 ratio for produced water from the Marcellus Shale has been determined to be less than 0.3 [Rowan and others, 2011] but no ratio has been established for the Utica/Point Pleasant formation because of a lack of data regarding produced waters.) Flowback and produced water contain elevated concentrations of total dissolved solids that, if accidentally released to streams, could potentially impair water quality and detrimentally affect aquatic life in surface waters (OEPA, 2014).

Shale-gas drilling in Ohio is most active along the eastern edge of the Muskingum River watershed where six of the MWCD lakes (Atwood, Leesville, Tappan, Clendening, Piedmont, and Senecaville Lakes) are used for recreation and flood control (fig. 3). Tappan Lake is also the source of water for the city of Cadiz (fig. 1) public water supply. To address concerns about the potential effects of shale-gas development on surface-water quality in areas of the Muskingum River watershed where people are most likely to be exposed to water, the U.S. Geological Survey (USGS), in cooperation with the MWCD, collected baseline (2015-16) water-quality data for these six lakes and their tributaries. Baseline waterquality data document current (2015-16) conditions that can be compared to future water-quality data to identify possible changes caused by shale-gas-production activities, should they occur.

\section{Purpose and Scope}

The purpose of this report is to (1) characterize baseline surface-water quality at 30 surface-water sites in the eastern part of the Muskingum River watershed where several popular recreational lakes are located and where shale-gas drilling is particularly focused, (2) evaluate the source of a few elevated chloride concentrations, (3) compare water quality at reference sites (sites with no shale-gas development) to water quality at non-reference sites, and (4) compare current (2015-16) chloride concentrations to historical chloride concentrations collected during comparable flow conditions at sites downstream of each lake.

Future water-quality data can be compared to these baseline data to identify changes in water quality that could result from increased oil and gas development or other activities. These data also provide context for the dissolved ions contributing to specific conductance that is measured continuously at 14 gages in the study area. Study results can be used by decision makers to effectively manage water resources and to protect and conserve water resources for beneficial public useshuman health, aquatic health, and environmental quality.

To characterize baseline water quality, USGS personnel collected samples from 30 sites - 20 sites on tributaries flowing to 6 lakes (Atwood, Leesville, Tappan, Clendening, Piedmont, and Senecaville), at swimming/recreational areas in 4 of the lakes (Atwood, Tappan, Piedmont, and Senecaville), and at sites near stream gages downstream from the dams at each of the 6 lakes (fig. 1). Because water quality can vary with changes in streamflow, samples were collected six times during the period April 2015 through May 2016 under a variety of streamflow conditions at each of these 30 sites. Results of water-quality analyses were compared to various aquatic life use criteria established by the OEPA to help determine if observed values have the potential to adversely affect aquatic life. Sources of chloride to streams were evaluated using graphical mixing models. Because human activities other than shale-gas development can affect water quality, selected environmental characteristics, such as number of conventional oil and gas wells, percentage of coal-mined area, miles of roads, and number of wastewater treatment outfalls, were quantified in the drainage basin upstream from each sampling site, and correlations to concentrations of selected constituents were evaluated. Historical concentrations of chloride (1960s-1980s) were compared to current (2015-16) concentrations collected at five lake-outflow gage sites to determine if median concentrations changed at these locations with time.

\section{Description of Study Area and Existing Monitoring Network}

The area of interest is along the eastern edge of the Muskingum River watershed (fig. 1), in Belmont, Carroll, Guernsey, Harrison, Monroe, Noble, and Tuscarawas Counties, an area with a history of coal mining and conventional oil and gas drilling. Several of the MWCD lakes are in this area, along with the most active counties for oil and gas development in Ohio in 2015 (ODNR, Division of Oil \& Gas Resources, 2017a), giving these lakes the potential to be 


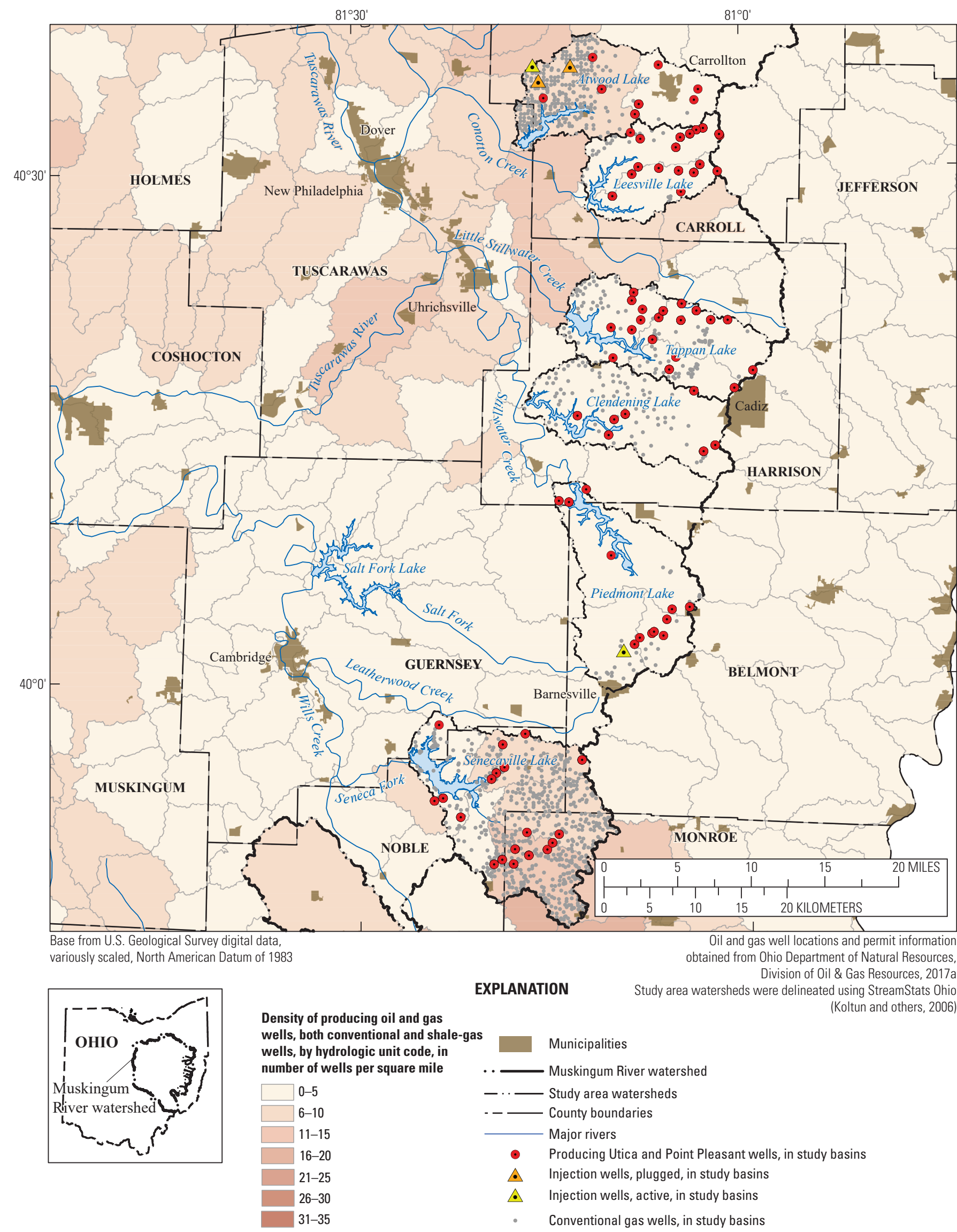

Figure 3. Density of conventional and horizontal oil and gas wells and waste injection wells in Muskingum River watershed, Ohio, June 2016. 
affected by shale-gas drilling activities. This study focused on the drainage areas to six lakes (listed from north to southAtwood, Leesville, Tappan, Clendening, Piedmont, and Senecaville Lakes), hereafter referred to as the "study area." The study area covers 463 square miles or about 5.75 percent of the Muskingum River watershed. Water from the five northern lakes flows into the Tuscarawas River (fig. 1) (a tributary of the Muskingum River), and water from the southernmost lake, Senecaville, drains to Wills Creek (fig. 1) (also a tributary of the Muskingum River). The dams at Atwood, Leesville, Clendening, Piedmont, and Senecaville Lakes release water from near the bottom of the lake at fixed points. A selective withdrawal system at Tappan Lake allows for mixing of water from near the bottom of the lake with water from a fixed point near the top of the lake ( 6 feet [ft)] below surface of summer pool or $1 \mathrm{ft}$ below surface of winter pool) (Jean Diedel, USACE, written commun., 2017). The six lakes lie in the unglaciated Appalachian Plateaus physiographic province (Fenneman and Johnson, 1946), which has hilly topography with steep valleys.

Average annual precipitation (1981-2010) in the region was 39.6 and 40.7 inches at weather stations operated by the National Weather Service in Cambridge (USC00331197) and Cadiz (USC00331152), respectively (fig. 1) (Midwestern Regional Climate Center, 2017). The baseline water-quality survey occurred from April 2015 through May 2016, by which time the station at Cadiz had been discontinued. Annual precipitation during 2015 at station USC00331197 in Cambridge was 1.49 inches higher than the long-term average (29 years) annual precipitation (table 1). Annual precipitation in 2016 was 1.79 inches less than the long-term average (29 years) annual precipitation.

Land cover in the drainage basins of the six lakes was predominantly forest (about 53-69 percent) and agricultural (about 16-29 percent) (table 2 and fig. 4). Developed lands in the drainage basins of the six lakes ranged from about 5 to 10 percent and included the cities of Carrollton and Barnesville (figs. 1 and 4).
Table 2. Major land cover in six lake drainage basins, Muskingum River watershed, Ohio, 2011.

[Rows do not add up to 100 percent because only major land covers were listed. Land cover data are from the 2011 National Land Cover Database (Homer and others, 2015)]

\begin{tabular}{lccc}
\hline \multirow{2}{*}{$\begin{array}{c}\text { Lake drainage } \\
\text { basins }\end{array}$} & \multicolumn{3}{c}{ Land cover type (percent) } \\
\cline { 2 - 4 } & Developed & Forest & Agricultural \\
\hline Atwood & 9.7 & 55.3 & 28.4 \\
Leesville & 5.3 & 61.9 & 27.1 \\
Tappan & 6.2 & 69.5 & 16.4 \\
Clendening & 5.3 & 66.3 & 21.1 \\
Piedmont & 6.3 & 53.6 & 28.7 \\
Senecaville & 6.5 & 69.0 & 17.8 \\
\hline
\end{tabular}

As part of a separate cooperative project with MWCD, gages were installed by USGS personnel in summer 2015 to monitor stream stage and specific conductance at 14 sites in the study area (shown as orange triangles in fig. 1). These sites were on the lower reaches of each significant tributary to the six lakes and gas wells drilled into the Utica/Point Pleasant formation are in the drainage basins upstream of the sites. The purpose of the gages was to detect spikes in specific conductance that might indicate the presence of brine spills (if any) that occur during oil and gas development activities. Meteorological stations that measure precipitation, temperature, evaporation, and other parameters were installed at each lake in November 2014. Additionally, the USGS and the USACE operated gages downstream from four of the six lakes since the late 1930s (Leesville, Tappan, Piedmont, and Senecaville). The gages Indian Fork below Atwood Dam near New Cumberland, Ohio, and Brushy Fork near Tippecanoe, Ohio (below Clendening Lake) were installed in 1960 and 2014, respectively. Streamflow is monitored so that the volume of discharge from the lakes can be determined. Only stream stage was monitored at five of the six gages from October 1991

Table 1. Monthly and annual total precipitation, in inches, during the study period compared to long-term average annual precipitation at climate station USC00331197 in Cambridge, Ohio.

[Data are from the Midwestern Regional Climate Center, cli-MATE (application tools environment), accessed June 27, 2017. Long-term average monthly and annual precipitation is for 1981-2010. Precipitation extremes (minimum and maximum total rainfall) are for period of record (August 1, 1948, to May 22, 2017). Blue shading indicates the time range of the baseline water-quality study. Gray shading indicates long-term average precipitation and monthly extremes]

\begin{tabular}{lccccccccccccc}
\hline \multicolumn{1}{c}{ Year } & Jan. & Feb. & Mar. & Apr. & May & June & July & Aug. & Sep. & Oct. & Nov. & Dec. & Annual \\
\hline 2015 & 2.86 & 1.51 & 3.86 & 5.82 & 3.86 & 6.95 & 3.00 & 1.12 & 5.24 & 1.19 & 2.58 & 3.10 & 41.09 \\
2016 & 1.31 & 3.02 & 3.94 & 4.27 & 3.22 & 4.64 & 1.92 & 3.98 & 3.05 & 2.48 & 1.57 & 4.41 & 37.81 \\
$\begin{array}{l}\text { Long-term } \\
\quad \text { average }\end{array}$ & 2.98 & 2.28 & 2.99 & 3.49 & 4.25 & 4.05 & 4.05 & 3.29 & 3.29 & 2.81 & 3.30 & 2.82 & 39.60 \\
$\begin{array}{l}\text { Minimum total } \\
\text { rainfall }\end{array}$ & 0.72 & 0.36 & 1.15 & 0.63 & 1.42 & 0.67 & 1.48 & 0.38 & 0.15 & 0.56 & 0.45 & 0.56 & 25.81 \\
$\begin{array}{l}\text { Maximum total } \\
\text { rainfall }\end{array}$ & 7.98 & 4.89 & 9.50 & 8.22 & 8.58 & 15.4 & 9.02 & 11.39 & 12.43 & 6.56 & 14.29 & 6.97 & 56.13 \\
\hline
\end{tabular}



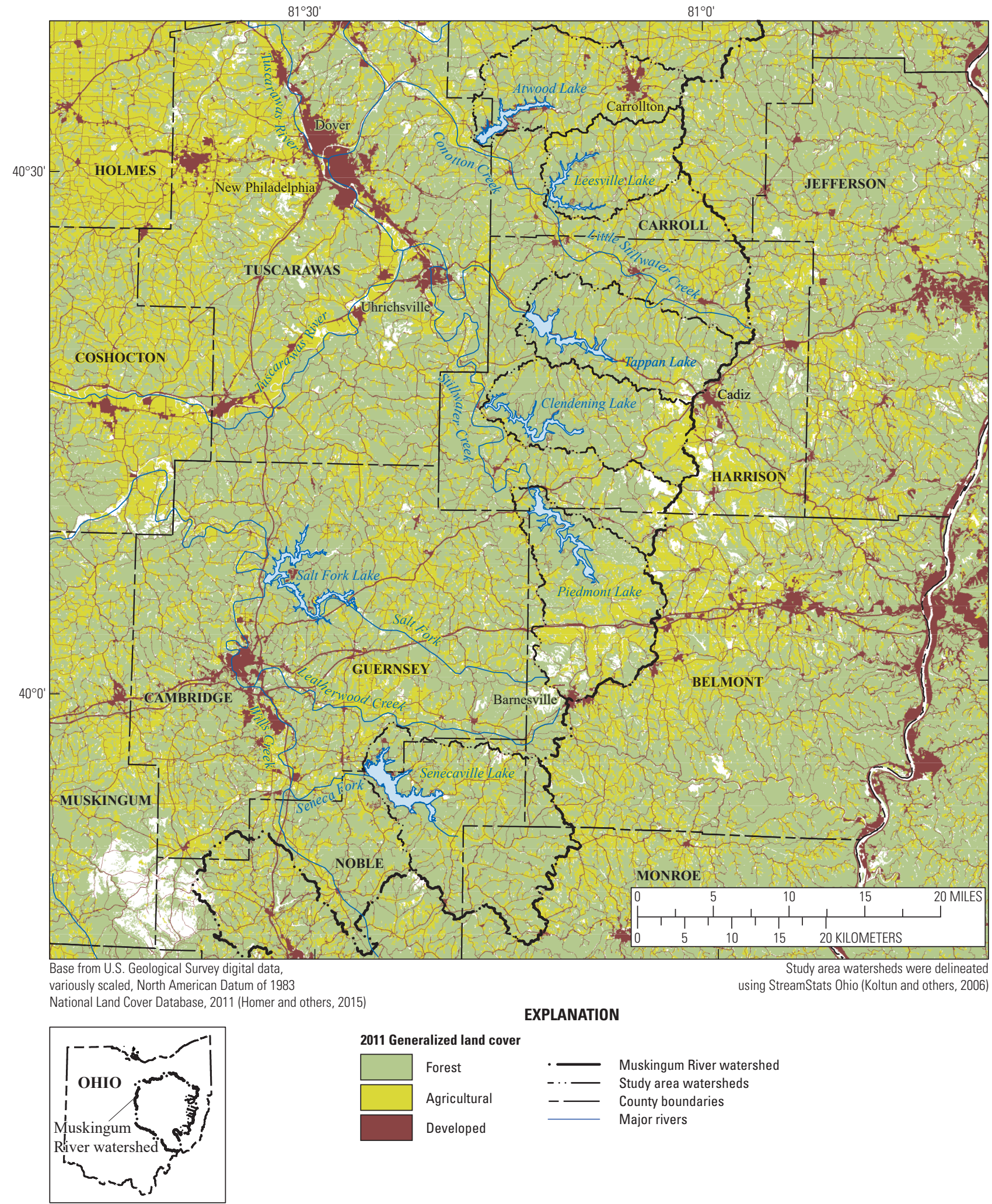

2011 Generalized land cover

\begin{tabular}{|c|c|c|}
\hline Forest & $\cdot \square$ & Muskingum River watershed \\
\hline Agricultural & 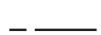 & scuay drea watersileus \\
\hline Developed & 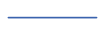 & Major rivers \\
\hline
\end{tabular}

Figure 4. Land covers within and around the study area, Muskingum River watershed, Ohio, 2015-16. 
through September 2014 (sometimes just as crest, or peak stage). At the sixth gage (Indian Fork below Atwood Dam near New Cumberland, Ohio), stage-only monitoring began earlier than at other sites-in October 1975.

\section{Hydrogeology}

The uppermost bedrock units in the study area are Pennsylvanian to Permian age and consist of (listed from oldest to youngest) the Allegheny Group (underlying Atwood and Leesville Lakes), the Conemaugh Group (in all lake drainage basins), the Monongahela Group (present in the drainage basins of the four southernmost lakes), and the Dunkard Group (present only in Piedmont and Senecaville Lakes drainage basins) (fig. 5) (USGS, 2005). Figure 5 shows a change in bedrock ages (older in the northwest corner to younger in the east/southeast). The Allegheny Group has several economically important layers of coal interbedded between layers of massive sandstone and thin limestone (Sedam and Francy, 1993). The Conemaugh Group has thick shale sequences, patchy sandstones, widespread limestones, and has fewer economically important (named) coal seams than either the Monongahela or Allegheny Groups. The Monongahela Group consists of proportionally more limestone and less sandstone than the other units listed. These three bedrock groups consist of layers of sandstone, shale, coal, clay, and limestone, as described by Sedam and Francy (1993, p. 10). The Dunkard Group consists of sandstones (some massive), with shales and minor coal beds. All four bedrock units compose the upper part of the Appalachian Plateaus aquifer (McCoy and others, 2015).

According to a regional Soil-Water-Balance model constructed for the Appalachian Plateaus physiographic province for 1980-2011 (McCoy and others, 2015), 62 percent of the precipitation falling on the land surface in this area is returned to the atmosphere as evapotranspiration. An average of 19 percent of precipitation runs off to streams, whereas another 19 percent infiltrates through the soil and into the aquifer. Once the precipitation reaches the water table, the infiltrating water (now called groundwater) flows downward and laterally with time through low-porosity sandstone units (Abate, 1993), coal seams (Harlow and LeCain, 1993), solution openings in limestone or dolostone (Ferrell, 1988), bedding planes beneath valley floors, and vertical and horizontal stress-relief fractures in valley walls (Wyrick and Borchers, 1981) to discharge to springs and streams.

During periods of rainfall, streamflow primarily consists of surface runoff; however, during dry periods, a part (or all) of streamflow may originate from groundwater discharge to streams (Todd, 1980). The part of streamflow originating from groundwater is referred to as "base flow." In the Appalachian Plateaus, base flow accounts for 60 to 65 percent of annual streamflow (Bloyd, 1974). Generally, the chemical characteristics of base flow can be affected by the aquifer matrix through which groundwater flows and the residence time of water in the aquifer. Analysis of age tracers in groundwater samples collected from seven shallow (less than $300 \mathrm{ft}$ deep) wells throughout the Tuscarawas River drainage basin indicate that the average residence time of sampled groundwater near the current (2015-16) study area is relatively short—less than 50 years - according to Haefner and Simonson (2010). Haefner and Simonson (2010) also determined that the "chemistry of shallow groundwater is closely related to land-use practices" in the Tuscarawas River drainage basin, based on a literature search of water-quality data and a comparison of the chemistry of the seven groundwater samples that were collected to overlying land use. Five of the six lake drainage basins included in the current study are in the Tuscarawas River drainage basin, although only one of the seven groundwater samples collected were actually in one of the lake drainage basins - that of Piedmont Lake.

\section{Coal Mining}

The study area lies within the Ohio coal region where more than 3.6 billion tons of coal have been extracted since 1800 (ODNR, Division of Mineral Resources Management [ODNR-DMRM], 2016). Active, legally closed (remediated), and abandoned lands associated with coal mines are present in 27 of the 30 drainage basins in this study (fig. 6). Belmont and Harrison Counties (where Tappan, Clendening, and Piedmont Lakes are located) were the top two coal-producing counties in the State in 2015 (Stucker, 2016). Mine drainage can contaminate streams and increase specific conductance and concentrations of total dissolved solids, sulfate, iron, manganese, arsenic, and aluminum (Helsel, 1983; Haefner and Simonson, 2010; ODNR-DMRM, 2016). Generally, mine drainage is acidic. However, in this study area, mine drainage tends to be alkaline because of interactions with limestone layers in the underlying bedrock (OEPA, 2017a). "Alkaline" in reference to mine drainage means that, before treatment, the $\mathrm{pH}$ is higher than or equal to 6.0, and total iron concentration is less than $10 \mathrm{mg} / \mathrm{L}$ (Electronic Code of Federal Regulations, 2018a).

Mine drainage from abandoned mine lands can cause drainage basins to be impaired so that they do not support a normal assemblage of aquatic life (ODNR-DMRM, 2016). The ODNR-DMRM identifies and prioritizes drainage basins that are impacted by mine drainage so that treatment and abatement projects can be implemented (ODNR-DMRM, 2016). In eastern Ohio, 122 streams (including some streams in the current [2015-16] study area) were sampled by Helsel (1983). Results of the sample analyses indicated that streams draining reclaimed mine lands have (1) $\mathrm{pH}$ and alkalinity similar to unmined lands underlain by the same rock type, (2) aluminum concentrations similar to those in unmined areas, and (3) iron concentrations slightly higher than those in unmined areas, with higher concentrations detected in areas underlain by the Allegheny Group rather than the Monongahela Group. Even after reclamation, however, sulfate concentrations and specific conductance detected in mined drainage basins remained higher than those detected in unmined drainage basins (Helsel, 1983). 


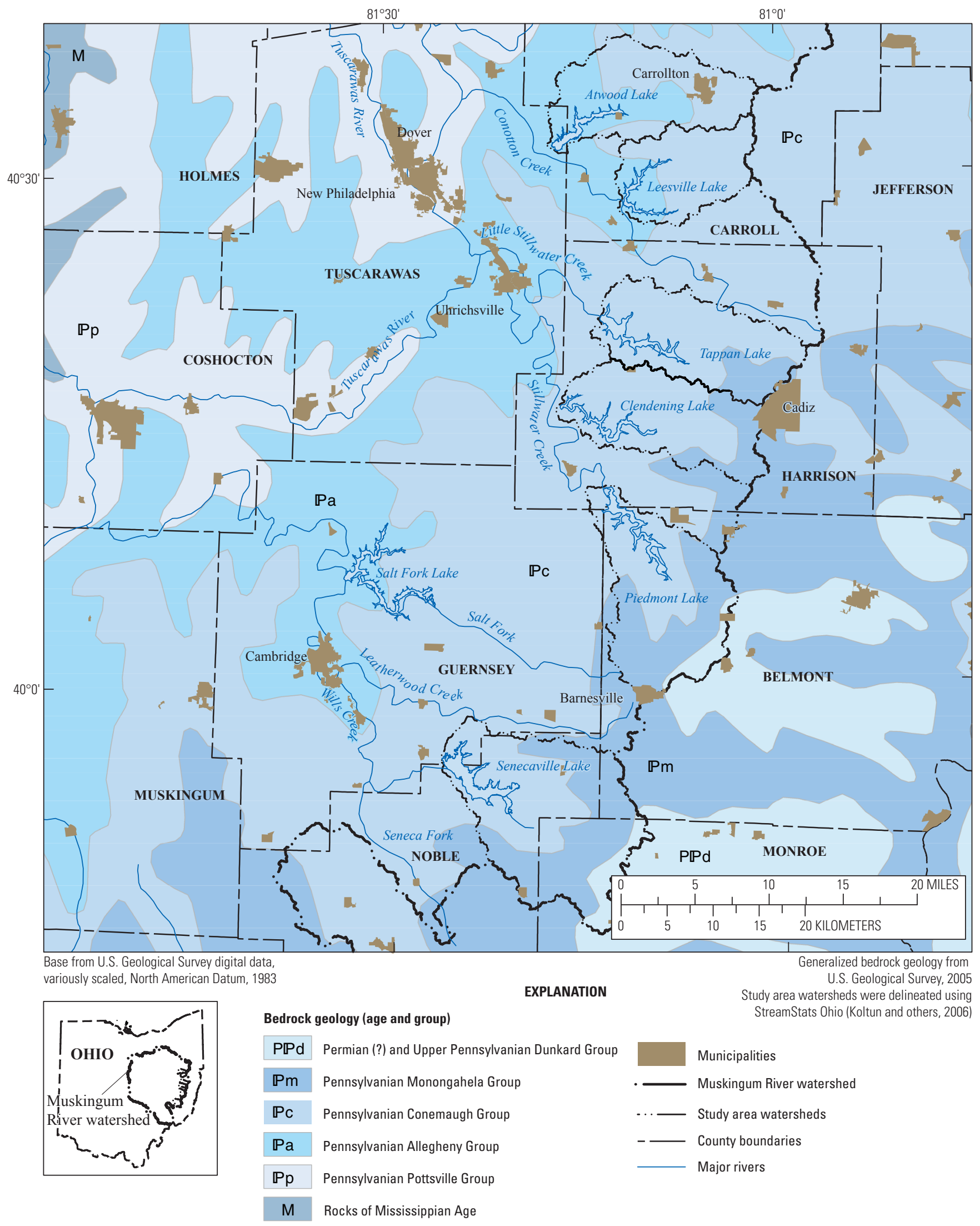

Figure 5. Bedrock geology in study area, Muskingum River watershed, Ohio, 2015-16. 


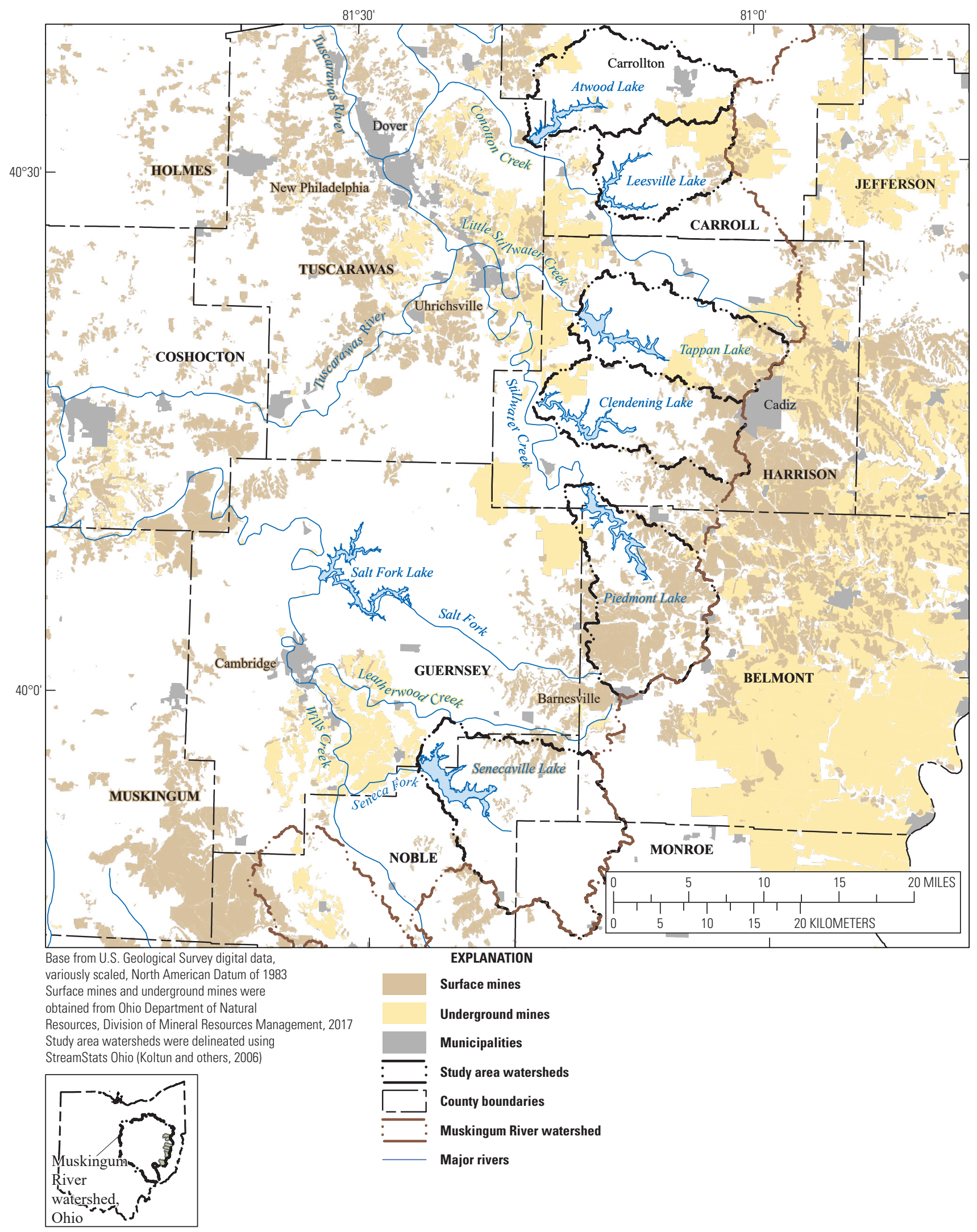

Figure 6. Lands associated with or affected by coal mines in the study area, Muskingum River watershed, Ohio, 2015-16. 


\section{Oil and Gas Drilling}

Oil and gas drilling has occurred in Ohio for more than 150 years (Ohio Oil and Gas Association, 2013). Commercial quantities of oil and gas were produced in 69 of the 88 counties in Ohio; however, most recent (2015-16) production was in the eastern one-third of the State (ODNR, Division of Geological Survey, 2004). With more than 65,000 wells currently (2015-16) in operation in Ohio, the ODNR-DMRM is responsible for regulating the permitting, drilling, and production of oil and natural gas resources in Ohio.

As of May 2016, approximately 1,209 conventional (vertical) oil and gas wells and 352 unconventional (horizontal) gas wells tapped the Utica/Point Pleasant formation in the study area (fig. 3). Most (by number) of the conventional wells were completed in the Clinton Sandstone (34.9 percent), Berea Sandstone (23.3 percent), Ohio Shale (11.7 percent), and Gordon Sandstone (7.9 percent) (ODNR, Division of Oil \& Gas Resources, 2017a).

Oil and gas development results in waste fluids - mostly brine that occurs naturally in the geologic formation being drilled - that are coproduced with the oil and gas and must be disposed of. In 2010, about 98 percent of oil-field fluids in Ohio were disposed of in Class II injection wells (and were stored in tanks prior to disposal), and 2 percent of oil-field fluids were spread on county, township, and village roads for dust and ice control (Tomastik, 2010). An active injection well is in each of the Atwood and Piedmont Lake drainage basins, and the Atwood Lake drainage basin also contains two plugged injection wells (ODNR, Division of Oil \& Gas Resources, 2017c) (fig. 3). In addition to oil-field fluids from Ohio, fluids disposed of in Ohio injection wells may originate from out of State. In 2014, approximately 60 percent of brines disposed of in injection wells in Ohio originated from out of State (ODNR, Division of Oil \& Gas Resources, 2015).

The ODNR-DMRM regulates the spreading of oil-field fluids on township roads for dust control in the State of Ohio. During the study sampling period (2015-16), within the drainage basins of the 6 lakes, permits to spread oil-field fluids were issued to 10 townships in Carroll County, 7 townships in Harrison County, 1 township in Guernsey County, and 2 townships in Monroe County (Kenny Brown, ODNR, Division of Oil \& Gas Resources, written commun., 2017). In February or March 2017, after sample collection for this study was completed, the following six townships changed their rules to no longer allow spreading of oil-field fluids: Washington Township in Carroll County; Green, Harrison, and Nottingham Townships in Harrison County; Londonderry Township in Guernsey County; and Seneca Township in Monroe County.

\section{Previous Studies}

During 1975-83, the USGS analyzed multiple surfacewater samples collected from the coal-producing area of Ohio. During 1975-76, the USGS collected water-quality samples from 150 streams during low-flow conditions (Pfaff and others, 1981; Helsel, 1983). In response to the Surface Mining Control and Reclamation Act of 1977, water quality samples were collected at 142 stream sites draining mined lands, reclaimed mine lands, and unmined lands (Engelke and others, 1981). During 1985-91, the USGS assessment of water quality in the coal region continued. The assessment included 41 stream sites that were sampled periodically as part of a longer-term network and 45 stream sites that were sampled once (Jones, 1988; Sedam, 1991; Sedam and Francy, 1993). Several of these USGS sampling sites (1975-91) lie within the current (2015-16) study area.

In the 1970s, the USACE began a large-scale waterquality sampling program on MWCD lakes to monitor the effects of the operation of the dams on water quality (MWCD, 2016). The USACE continues to sample an average of 2 lakes a year for more than 46 parameters, including concentrations of 27 metals, 4 nutrients, 9 major ions, 3 physical parameters, and 3 measures of suspended and dissolved material.

The MWCD collaborates with the Ohio Lake Management Society Citizen Lake Awareness and Monitoring program to collect a variety of information at MWCD lakes. Citizen Lake Awareness and Monitoring citizen-scientists have been monitoring and collecting algae samples at park beaches at Atwood, Seneca, and Tappan Lakes. Similarly, since 2010, the MWCD and USGS have collaborated to sample for bacteria at the same park beaches.

During 2011-15, the OEPA sampled 31 streams at 63 locations and 3 lakes (Tappan, Clendening, and Piedmont) at 6 locations in the Stillwater Creek drainage basin as part of a statewide, annual stream water-quality monitoring and assessment program (OEPA, 2017a). As part of the program, 50 biological (2012), 63 water-chemistry (2011-15), 9 sediment (2012), 8 fish-tissue (2012), and 23 bacterial (2012) sites were sampled in the study area.

To further assist in the development of acid mine drainage abatement and treatment plans, the Abandoned Mine Land Program (ODNR-DMRM, 2016), assessed drainage basins in Ohio that were impacted by abandoned mine land. The program developed criteria to identify and assess the severity of mining impacts based on concentrations of eight water-quality constituents and properties.

A variety of water-related and other projects in the study area can be viewed online at the MWCD website (https://www.mwcd.org/projects). A more thorough list and description of historical water-related studies in the Tuscarawas River watershed is given in Haefner and Simonson (2010).

\section{Site Selection}

Thirty sites (fig. 1 and table 3) were selected for baseline sampling. Fourteen sampling sites were colocated with the 14 gages that monitor stream stage and specific conductance as part of another USGS/MWCD project (fig. 1). These sites 
Table 3. Site information for 30 sites in baseline water-quality study in Muskingum River watershed, 0hio, 2015-16.

[Site types are defined as follows: stream, sites were located on tributaries to the six lakes and contained shale-gas wells completed in the Utica Shale or the Point Pleasant Limestone in their upstream drainage basins; reference, sites (one for each lake) were selected on tributaries with no to little permitted or existing Utica/ Point Pleasant shale-gas wells and as few conventional oil and gas wells and mining operations as possible in upstream portions of their drainage basins; lake, sites located at swimming/recreational areas (Tappan Lake, Atwood Lake, Piedmont Lake, and Senecaville Lake); gage, sites were located at the U.S. Geological Survey (USGS) gages downstream from each lake to coincide with locations where historical streamflow and water-quality data were collected. Sites are listed in order by lake, north to south and by site, smallest to largest drainage area. ID, identification; mi ${ }^{2}$, square mile; ${ }^{\circ}$, degrees; ', minutes; ", seconds]

\begin{tabular}{|c|c|c|c|c|c|c|c|}
\hline $\begin{array}{c}\text { Site } \\
\text { ID } \\
\text { (fig. 1) }\end{array}$ & Site name & $\begin{array}{c}\text { USGS } \\
\text { station number }\end{array}$ & Site type & $\begin{array}{c}\text { Drainage } \\
\text { area } \\
\left(\mathrm{mi}^{2}\right)\end{array}$ & Latitude & Longitude & County \\
\hline \multicolumn{8}{|c|}{ Atwood Lake } \\
\hline 1 & Unnamed tributary near Dellroy, Ohio & 03120961 & Stream & 3.38 & $40^{\circ} 34^{\prime} 05^{\prime \prime}$ & $81^{\circ} 15^{\prime} 26^{\prime \prime}$ & Carroll \\
\hline 2 & Elliot Run near Dellroy, Ohio & 403441081125300 & Reference & 3.5 & $40^{\circ} 34^{\prime} 41.37^{\prime \prime}$ & $81^{\circ} 12^{\prime} 53.10^{\prime \prime}$ & Carroll \\
\hline 3 & Willow Run near Dellroy, Ohio & 03120869 & Stream & 7.78 & $40^{\circ} 34^{\prime} 41^{\prime \prime}$ & $81^{\circ} 11^{\prime} 34^{\prime \prime}$ & Carroll \\
\hline 4 & Indian Fork at Dellroy, Ohio & 03120820 & Stream & 37.9 & $40^{\circ} 33^{\prime} 13^{\prime \prime}$ & $81^{\circ} 11^{\prime} 5^{\prime \prime}$ & Carroll \\
\hline 5 & Atwood Lake at Main Swimmers Beach, Ohio & 403219081155500 & Lake & 70 & $40^{\circ} 32^{\prime} 19^{\prime \prime}$ & $81^{\circ} 15^{\prime} 55^{\prime \prime}$ & Carroll \\
\hline 6 & $\begin{array}{l}\text { Indian Fork below Atwood Dam near New } \\
\text { Cumberland, Ohio }\end{array}$ & 03121500 & Gage & 70 & $40^{\circ} 31^{\prime} 31^{\prime \prime}$ & $81^{\circ} 17^{\prime} 18^{\prime \prime}$ & Carroll \\
\hline \multicolumn{8}{|c|}{ Leesville Lake } \\
\hline 7 & Bear Hole Run near Carrollton, Ohio & 03119979 & Stream & 1.43 & $40^{\circ} 31^{\prime} 44^{\prime \prime}$ & $81^{\circ} 8^{\prime} 13^{\prime \prime}$ & Carroll \\
\hline 8 & $\begin{array}{l}\text { Unnamed tributary to McGuire Creek near } \\
\text { Carrolltown, Ohio }\end{array}$ & 403052081063100 & Reference & 9.42 & $40^{\circ} 30^{\prime} 52^{\prime \prime}$ & $81^{\circ} 6^{\prime} 30.56^{\prime \prime}$ & Carroll \\
\hline 9 & North Fork McGuire Creek near Carrollton, Ohio & 03119971 & Stream & 11.3 & $40^{\circ} 30^{\prime} 48^{\prime \prime}$ & $81^{\circ} 06^{\prime} 46^{\prime \prime}$ & Carroll \\
\hline 10 & McGuire Creek above Leesville Lake, Ohio & 03119341 & Stream & 13 & $40^{\circ} 27^{\prime} 42.29^{\prime \prime}$ & $81^{\circ} 07^{\prime} 31.61^{\prime \prime}$ & Carroll \\
\hline 11 & McGuire Creek near Leesville, Ohio & 03120500 & Gage & 48.3 & $40^{\circ} 28^{\prime} 13^{\prime \prime}$ & $81^{\circ} 11^{\prime} 48^{\prime \prime}$ & Carroll \\
\hline \multicolumn{8}{|c|}{ Tappan Lake } \\
\hline 12 & Unnamed ditch tributary to Tappan Lake, Ohio & 401910081111200 & Reference & 0.85 & $40^{\circ} 19^{\prime} 9.52^{\prime \prime}$ & $81^{\circ} 11^{\prime} 11.9^{\prime \prime}$ & Harrison \\
\hline 13 & Beaverdam Run above Tappan Lake, Ohio & 03127989 & Stream & 3.5 & $40^{\circ} 20^{\prime} 48.79^{\prime \prime}$ & $81^{\circ} 07^{\prime} 36.34^{\prime \prime}$ & Harrison \\
\hline 14 & Standingstone Fork above Tappan Lake, Ohio & 03127986 & Stream & 13.5 & $40^{\circ} 18^{\prime} 42^{\prime \prime}$ & $81^{\circ} 6^{\prime} 55^{\prime \prime}$ & Harrison \\
\hline 15 & Clear Fork above Tappan Lake, Ohio & 03127980 & Stream & 23.3 & $40^{\circ} 20^{\prime} 19.04^{\prime \prime}$ & $81^{\circ} 06^{\prime} 50.08^{\prime \prime}$ & Harrison \\
\hline 16 & Tappan Lake at Main Swimmers Beach, Ohio & 401926081105100 & Lake & 71.1 & $40^{\circ} 19^{\prime} 26^{\prime \prime}$ & $81^{\circ} 10^{\prime} 51.3^{\prime \prime}$ & Harrison \\
\hline 17 & $\begin{array}{l}\text { Little Stillwater Creek below Tappan Dam at } \\
\text { Tappan, Ohio }\end{array}$ & 03128500 & Gage & 71.1 & $40^{\circ} 21^{\prime} 25^{\prime \prime}$ & $81^{\circ} 13^{\prime} 49^{\prime \prime}$ & Harrison \\
\hline \multicolumn{8}{|c|}{ Clendening Lake } \\
\hline 18 & Coleman Run above Clendening Lake, Ohio & 401657081125600 & Reference & 2.86 & $40^{\circ} 16^{\prime} 56.9^{\prime \prime}$ & $81^{\circ} 12^{\prime} 56.4^{\prime \prime}$ & Harrison \\
\hline 19 & Brushy Fork above Clendening Lake, Ohio & 03126395 & Stream & 35.9 & $40^{\circ} 14^{\prime} 52^{\prime \prime}$ & $81^{\circ} 8^{\prime} 54^{\prime \prime}$ & Harrison \\
\hline 20 & Brushy Fork near Tippecanoe, Ohio & 03126910 & Gage & 70 & $40^{\circ} 15^{\prime} 58^{\prime \prime}$ & $81^{\circ} 17^{\prime} 3^{\prime \prime}$ & Harrison \\
\hline \multicolumn{8}{|c|}{ Piedmont Lake } \\
\hline 21 & Robinson Run above Piedmont Lake, Ohio & 400606081085700 & Reference & 6.06 & $40^{\circ} 6^{\prime} 6.4^{\prime \prime}$ & $81^{\circ} 8^{\prime} 57.1^{\prime \prime}$ & Belmont \\
\hline 22 & Stillwater Creek above Piedmont Lake, Ohio & 03125338 & Stream & 37.9 & $40^{\circ} 5^{\prime} 03^{\prime \prime}$ & $81^{\circ} 7^{\prime} 38^{\prime \prime}$ & Belmont \\
\hline 23 & Piedmont Lake near Piedmont, Ohio & 400925081105700 & Lake & 85.8 & $40^{\circ} 9^{\prime} 25^{\prime \prime}$ & $81^{\circ} 10^{\prime} 57^{\prime \prime}$ & Guernsey \\
\hline 24 & $\begin{array}{l}\text { Stillwater Creek below Piedmont Dam near } \\
\text { Piedmont, Ohio }\end{array}$ & 401139081125400 & Gage $^{1}$ & 85.8 & $40^{\circ} 11^{\prime} 39^{\prime \prime}$ & $81^{\circ} 12^{\prime} 54^{\prime \prime}$ & Harrison \\
\hline \multicolumn{8}{|c|}{ Senecaville Lake } \\
\hline 25 & Glady Run above Senecaville Lake, Ohio & 395150081204000 & Reference & 8.29 & $39^{\circ} 51^{\prime} 50.33^{\prime \prime}$ & $81^{\circ} 20^{\prime} 39.6^{\prime \prime}$ & Noble \\
\hline 26 & Beaver Creek above Senecaville Lake, Ohio & 03140950 & Stream & 17 & $39^{\circ} 54^{\prime} 05^{\prime \prime}$ & $81^{\circ} 19^{\prime} 10^{\prime \prime}$ & Noble \\
\hline 27 & South Fork at TR199 above Senecaville Lake, Ohio & 395036081190200 & Stream & 27.5 & $39^{\circ} 50^{\prime} 36^{\prime \prime}$ & $81^{\circ} 19^{\prime} 02^{\prime \prime}$ & Noble \\
\hline 28 & Seneca Fork above Senecaville Lake, Ohio & 03140853 & Stream & 29.1 & $39^{\circ} 51^{\prime} 49.8^{\prime \prime}$ & $81^{\circ} 19^{\prime} 14.6^{\prime \prime}$ & Noble \\
\hline 29 & $\begin{array}{l}\text { Seneca Lake at Swimming Beach near } \\
\text { Senecaville, Ohio }\end{array}$ & 395433081250100 & Lake & 118 & $39^{\circ} 54^{\prime} 33^{\prime \prime}$ & $81^{\circ} 25^{\prime} 1^{\prime \prime}$ & Noble \\
\hline 30 & $\begin{array}{l}\text { Seneca Fork below Senecaville Dam near } \\
\text { Senecaville, Ohio }\end{array}$ & 03141500 & Gage & 118 & $39^{\circ} 55^{\prime} 28^{\prime \prime}$ & $81^{\circ} 26^{\prime} 17^{\prime \prime}$ & Noble \\
\hline
\end{tabular}

${ }^{1}$ Gage is at Stillwater Creek at Piedmont, Ohio (USGS station number 03126000). Baseline water-quality samples were collected upstream of the gage at USGS station number 401139081125400, before inflow from Boggs Fork into Stillwater Creek. 
were on tributaries to the six lakes and contained Utica/Point Pleasant shale-gas wells in their upstream drainage basins. Six sites (one for each lake) were selected on tributaries with no to little permitted or existing shale-gas wells drilled into the Utica/Point Pleasant formation and as few conventional oil and gas wells and mining operations as possible in upstream parts of their drainage basins and are hereafter referred to as "reference sites." Six additional sites were at the USGS gages downstream from each lake to coincide with locations where historical streamflow and water-quality data were collected. Four lake sites also were selected at swimming/recreational areas (Tappan, Atwood, Piedmont, and Senecaville Lakes).

The 14-stream stage and specific conductance gages were not installed until summer 2015 (after the first 2 rounds of baseline water-quality samples were collected); therefore, a few discrepancies exist between baseline sampling sites and gage locations. South Fork above Senecaville Lake, Ohio (USGS station number 03140900) (28.3 square miles), was installed a short distance downstream from where the water-quality samples were collected (South Fork at TR199 above Senecaville Lake, Ohio [USGS station number 395036081190200] [27.5 square miles]). Also, because of the relocations of two stream stage and specific conductance gage sites, water-quality samples were collected only five times at Brushy Fork above Clendening Lake, Ohio (USGS station number 03126395), and four times at Stillwater Creek above Piedmont Lake, Ohio (USGS station number 03125338).

\section{Sampling Methods and Laboratory Analysis}

Water-quality data collected for this study included field parameters and major ions, metals, trace elements, nutrients, VOCs, radionuclides, and suspended sediment (table 4). These data were used to identify different sources of water-for example, water derived from contact with the Utica/Point Pleasant formation (flowback from hydraulic fracturing or formation water), produced water from conventional oil and gas wells, sewage effluent, or coal-mine drainage. During a variety of flow conditions from April 2015 through May 2016, samples were collected four to six times at each site. Two sites-Brushy Fork above Clendening Lake, Ohio, and Stillwater Creek above Piedmont Lake, Ohio-were sampled fewer than six times. Streamflow was measured to document flow conditions at the time of sampling. Because of complications with high water (stream was deeper than anticipated, stream could not be waded, and equipment needed to measure discharge from a bridge or boat was not immediately available), streamflow could not be measured on the same day that the water-quality samples were collected for 7 of the 177 samples (table 5).

Hydrographs from two nearby gaging stations - USGS station number 03121850 northwest of Atwood Lake and USGS station number 03141870 northwest of Senecaville
Lake (figs. 1 and $7 A-7 B$ ), hereafter referred to as "index gages"-were used to evaluate the suitability of using a later discharge measurement to estimate discharge at the time of sample collection. During April 14-16, 2015, streamflow at the two index gages was steeply receding. Thus, discharge measurements made during this period (table 5) likely underestimate the discharge on an earlier date. During April 20-21, 2015 , streamflow was slowly receding at the northern index gage (fig. $7 A$ ), so the streamflow measurement made during this period, near the northern end of the study area at McGuire Creek above Leesville Lake, Ohio (table 5), is deemed to be a reasonable approximation of streamflow on the sample collection date. Finally, streamflow at both index gages (figs. $7 A-7 B$ ) was stable on June $2-3,2015$, so discharge measurements made during this period (table 5) are deemed to be a reasonable approximation of streamflow on the sample collection date. In subsequent sections of this report, streamflows at an individual site are ranked and classified as above- or below-median streamflow. These rankings will not be affected by the three underestimated discharges (table 5) because these three measurements were already in the above-median flow category. However, the range of discharge values observed at these three sites may be slightly underestimated.

At each of the 26 stream sites, when possible, depthintegrated, isokinetic samples were collected with a DH-81 sampler using an equal-width-increment method described in the USGS National Field Manual (USGS, variously dated). When water depth was less than $0.3 \mathrm{ft}$, grab sample(s) were collected at one or more points across the stream channel using a sample bottle. When stream velocity was less than 1.5 feet per second, grab sample(s) were collected through the vertical water column at one or more points across the stream channel using a DH-81 sampler. Samples were composited in a churn splitter. At each of three lake sites (Atwood, Tappan, and Senecaville), water samples were collected and composited from three wadable locations. At the Piedmont Lake site, water samples were collected and composited from the side of a dock. For the lake sites, a DH-81 sampler was lowered and raised at a uniform rate, similar to stream samples, from just below the water surface to approximately $3.5 \mathrm{ft}$ and back to the surface.

Water-quality samples were processed using standard USGS methods (USGS, variously dated; Wilde and others, variously dated). All samples were analyzed for alkalinity, total dissolved solids, metals, major ions, trace elements, nutrients, dissolved organic carbon, radium-226 and radium-228, selected VOCs, and suspended sediment (table 4). Field measurements of water temperature, specific conductance, dissolved oxygen concentration, $\mathrm{pH}$, and alkalinity were made onsite according to standard protocols (USGS, variously dated). Water temperature, specific conductance, $\mathrm{pH}$, and dissolved oxygen were measured using YSI data sondes, and the reported value of each was the median of at least three readings taken across the stream cross section. Sulfide concentration was measured, for grab samples collected in the thalweg or the deepest point in the cross 


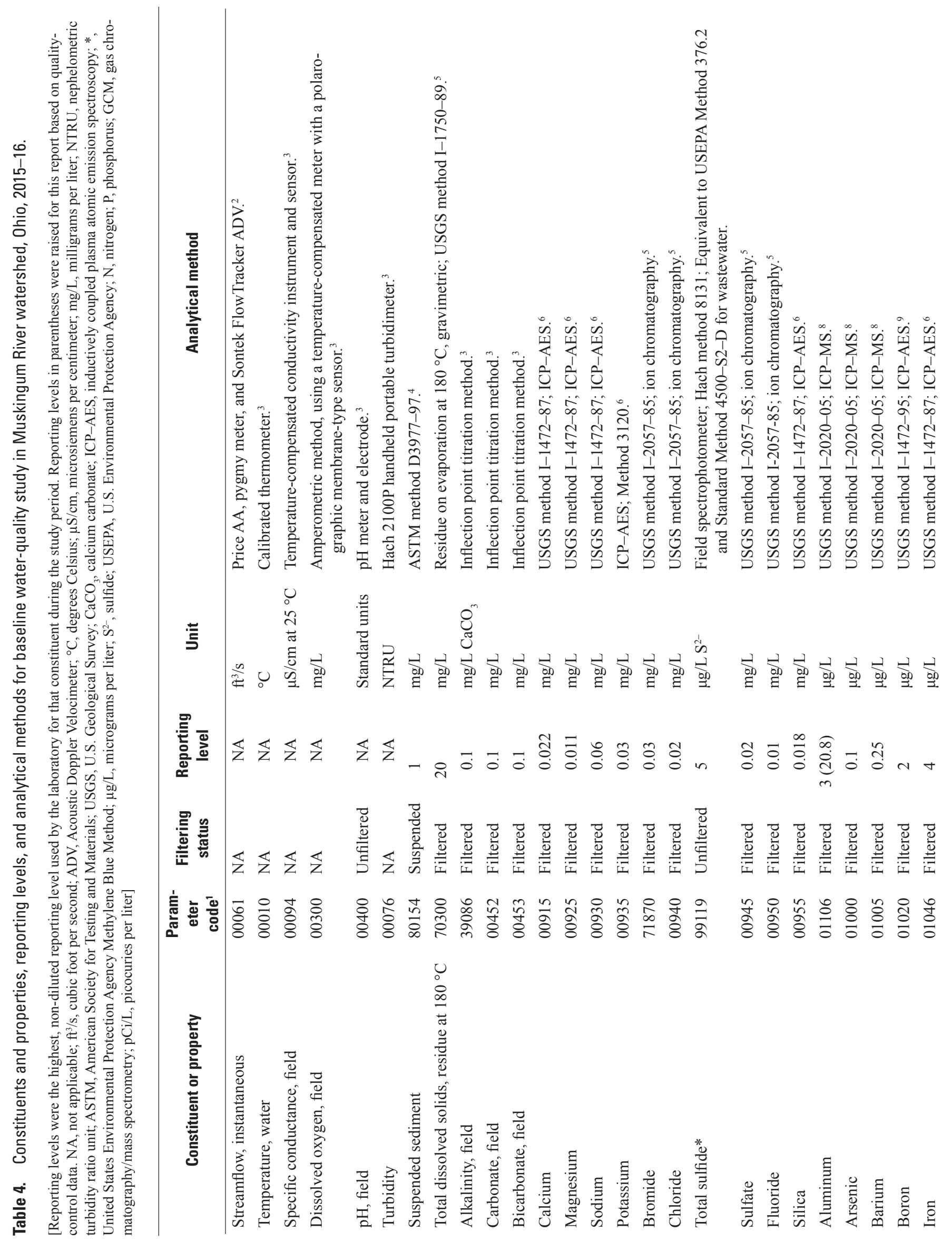




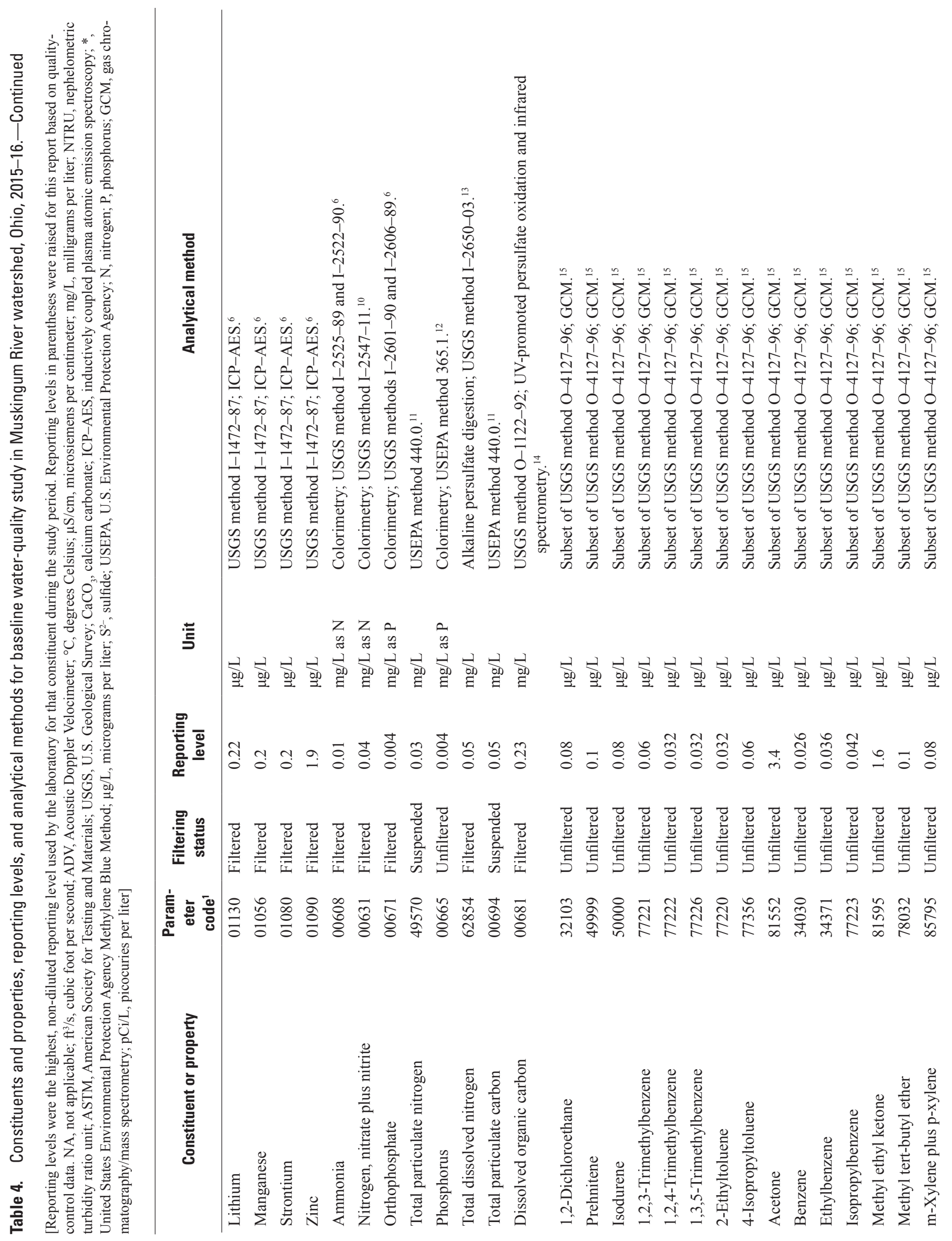




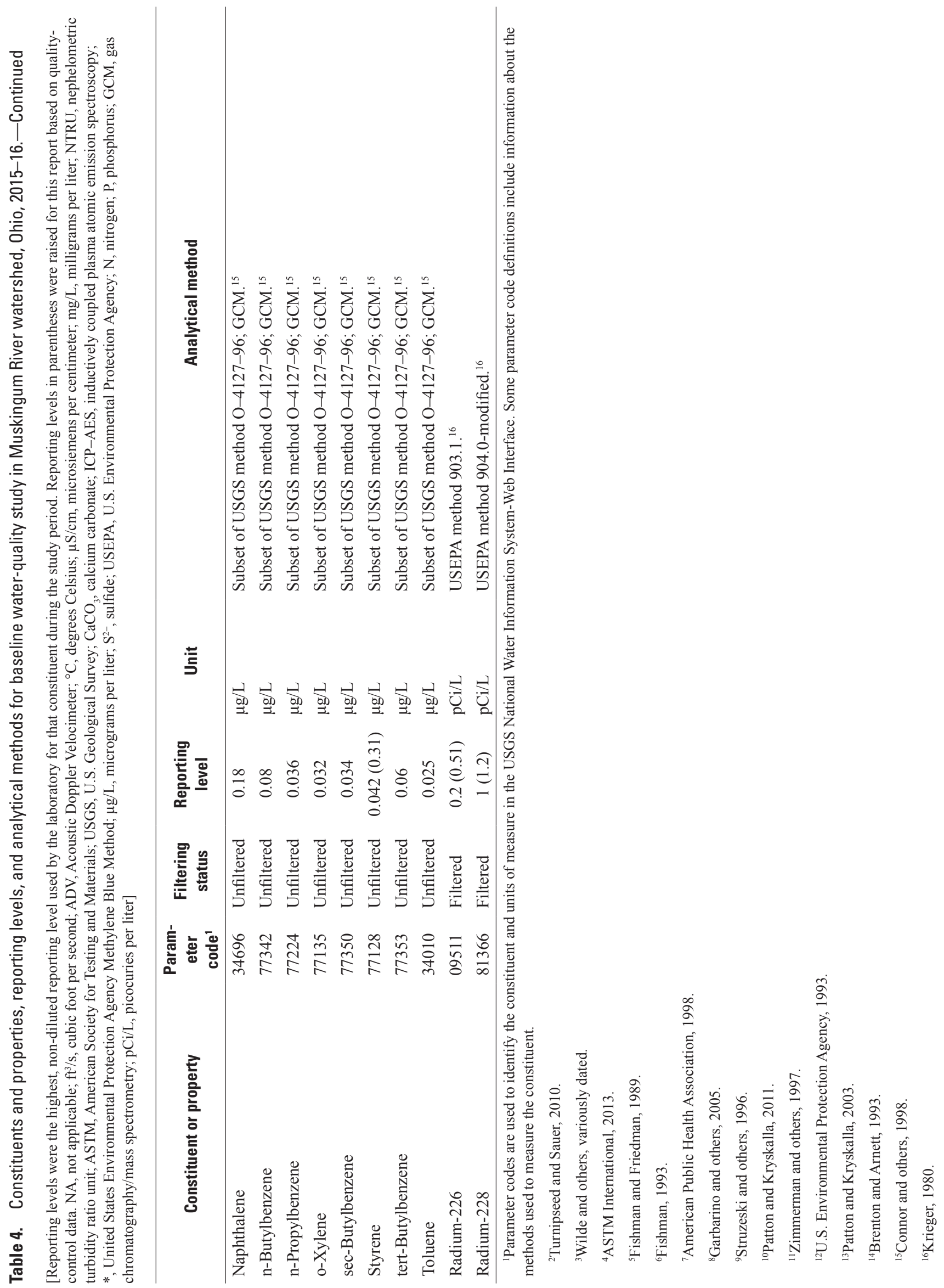


Table 5. Water-quality sample-collection sites where discharge at the time of sample collection was estimated using a measurement made on a later date, April-June 2015.

[ID, identification]

\begin{tabular}{|c|c|c|c|c|}
\hline \multirow[b]{2}{*}{$\begin{array}{l}\text { Site ID } \\
\text { (fig. 1) }\end{array}$} & \multirow[b]{2}{*}{ Site name } & \multicolumn{2}{|c|}{ Date } & \multirow{2}{*}{$\begin{array}{l}\text { Is the discharge measurement a reasonable } \\
\text { approximation of discharge at the time the water-quality } \\
\text { sample was collected, based on hydrographs } \\
\text { of nearby streams (fig. 7)? }\end{array}$} \\
\hline & & $\begin{array}{l}\text { Water- } \\
\text { quality } \\
\text { sample }\end{array}$ & $\begin{array}{c}\text { Discharge } \\
\text { measure- } \\
\text { ment }\end{array}$ & \\
\hline \multirow[t]{2}{*}{4} & Indian Fork at Dellroy, Ohio & $4 / 14 / 2015$ & $4 / 15 / 2015$ & Discharge is likely underestimated. \\
\hline & & $6 / 2 / 2015$ & $6 / 3 / 2015$ & Discharge is a reasonable approximation. \\
\hline 6 & $\begin{array}{l}\text { Indian Fork below Atwood Dam near } \\
\text { New Cumberland, Ohio }{ }^{1}\end{array}$ & $4 / 13 / 2015$ & $4 / 16 / 2015$ & Discharge is likely underestimated. \\
\hline \multirow[t]{2}{*}{10} & McGuire Creek above Leesville Lake, Ohio & $4 / 20 / 2015$ & $4 / 21 / 2015$ & Discharge is a reasonable approximation. \\
\hline & & $6 / 2 / 2015$ & $6 / 3 / 2015$ & Discharge is a reasonable approximation. \\
\hline 15 & Clear Fork above Tappan Lake, Ohio & $4 / 15 / 2015$ & $4 / 16 / 2015$ & Discharge is likely underestimated. \\
\hline 24 & $\begin{array}{l}\text { Stillwater Creek below Piedmont Dam near } \\
\text { Piedmont, Ohio }\end{array}$ & $4 / 20 / 2015$ & $4 / 21 / 2015$ & $\begin{array}{l}\text { Discharge is an invalid approximation because the water- } \\
\text { quality samples were collected just below the dam, } \\
\text { upstream of Boggs Creek and streamflow was measured } \\
\text { a short distance downstream at gage } 03126000 \text {, down- } \\
\text { stream from Boggs Creek. No discharge measurement } \\
\text { is associated with this sample. }\end{array}$ \\
\hline
\end{tabular}

${ }^{1}$ Gage not operational during this time period, so discharge cannot be determined from the gage. Also, above a gage height of 7 feet, backwater can occur, so stage-discharge relation is not valid for estimating discharge.

section in the field, with a Hach DR2000 spectrophotometer by use of the methylene blue method (Hach Company, 1989). Turbidity was measured on a part of the unfiltered, composited sample (obtained from churn splitter) in the field using a portable Hach 2100P turbidimeter. Alkalinity was measured on a part of the unfiltered, composited sample in the field using a Beckman $250 \mathrm{pH}$ meter. Analyses for total dissolved solids, metals, major ions, trace elements, nutrients, VOCs, and dissolved organic carbon were done at the USGS National Water Quality Laboratory (NWQL) in Denver, Colorado. Analyses for radium-226 and radium-228 were done at ALS Environmental, an NWQL-contracted laboratory in Fort Collins, Colo. Suspended sediment analyses were done at a USGS laboratory in Louisville, Ky. Analytical methods are listed in table 4.

The terms "detection limits," "reporting levels," and "censored values" are often used in discussions of chemical concentrations. The detection limit is traditionally defined as the lowest concentration (or amount) of analyte that can be measured and reported with 99 percent confidence that the analyte concentration is higher than zero (Electronic Code of Federal Regulations, 2018b). The reporting level is the lowest measured concentration that may be reliably measured, is determined statistically, and may be higher than the detection limit (NWQL Technical Memorandum 15.02). Censored values are values less than the detection limit or reporting level and are reported using a less-than sign $(<)$ in front of either the detection limit or reporting level value. Censored values often are referred to as "nondetections," whereas values higher than the censored values are referred to as "detections." The nondetections for all constituents in this report are reported as less than the detection limit except for VOCs. The USGS includes measurements of VOCs that are less than the reporting level but higher than the detection limit. Within this range, detected VOCs are present, but the quantification is not as certain as it is for concentrations higher than the reporting level. For the purposes of this report, the term "reporting level" will be used to represent the lowest concentration (or amount) reported by the laboratory, regardless of the analytical method used. In some instances, reporting levels decreased during the project, which resulted in situations where analytical values normally considered nondetections when compared to the original reporting level were higher than the new, decreased reporting level and considered detections. In these cases of multiple reporting levels, prior to statistical analyses, results were censored to a common reporting level equal to the highest nondiluted reporting level used by the laboratory for that constituent during the study period, as reported in table 4 . For example, from October 1, 2014, through September 30, 2015, the reporting level for bromide was $0.03 \mathrm{mg} / \mathrm{L}$. Starting on October 1, 2015, the reporting level changed to $0.01 \mathrm{mg} / \mathrm{L}$. Values less than $0.03 \mathrm{mg} / \mathrm{L}$ reported after October 1, 2015, are thus treated as censored values (in this case, $<0.03 \mathrm{mg} / \mathrm{L}$ ) for statistical purposes. The analytical results are available online from the USGS National Water Information System (NWIS) database (USGS, 2017a). USGS station numbers (table 3) and parameter codes (table 4) are needed to retrieve these data. 
03121850 Huff Run at Mineral City, Ohio
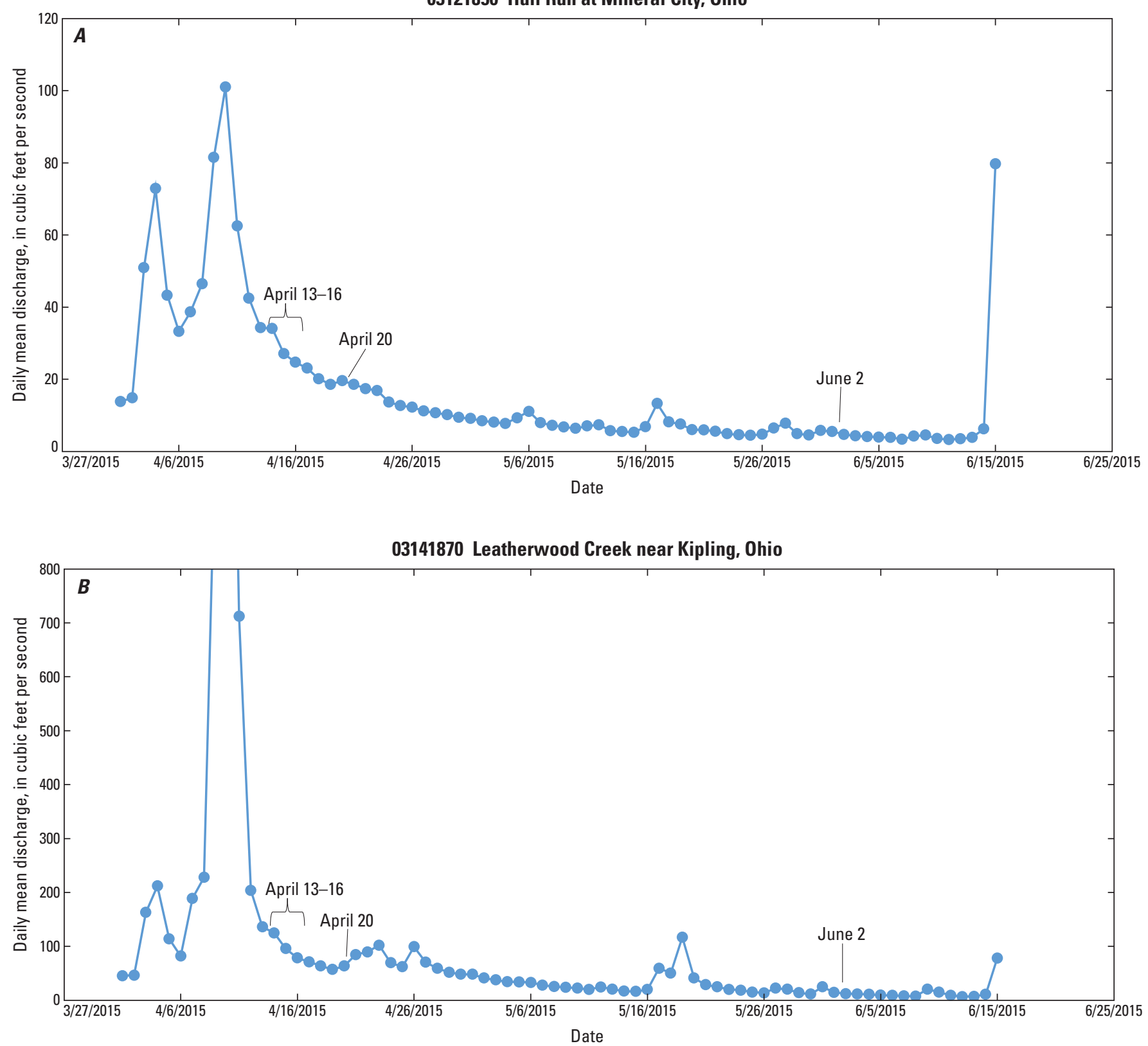

Figure 7. U.S. Geological Survey gaging stations $A, 03121850$ Huff Run at Mineral City, Ohio, and $B, 03141870$ Leatherwood Creek near Kipling, Ohio, April 1 through June 15, 2015. 


\section{Data Analysis and Statistical Methods}

Water-chemistry results and geospatial data that included natural and anthropogenic characteristics were examined for patterns and relations. Details of these analyses are described in the "Geospatial Analyses" and "Statistical Analyses" sections.

\section{Geospatial Analyses}

Geospatial data (table 6) were obtained and compiled using ArcMap (Esri, 2017), a geographic information system (GIS) tool, to assess potential relations and impacts on water quality. Drainage basin boundaries were delineated using StreamStats-a USGS, GIS-based web application that allows users to obtain the drainage-basin boundary upstream of a single point (Koltun and others, 2006). These drainage basins were used to summarize a variety of environmental data and human-based activities occurring within each upstream drainage basin. The geospatial data of human-based activities for each drainage basin were divided by the drainage area of the basin — producing a number per square mile - to help account for bias introduced by drainage basin areas.

\section{Statistical Analyses}

Censored-style boxplots were created using a USGSdeveloped function/package (boxPlot.lcens/smwrQW) in RStudio software (RStudio, Inc., 2016) to compare the range, median, and outliers of the water-chemistry data. Values that were less than the reporting level were used in the calculations but were visually truncated at the censored-value line.

The coefficient of determination $\left(R^{2}\right)$ is a measure of the goodness of fit for a linear regression model and is expressed as the percentage variation of the response variable that is explained by the linear model. The $R^{2}$ was used to examine the relations among specific conductance and concentrations of sulfate, bicarbonate, and chloride in streams. The $R^{2}$ values range from 0 to 1 . The higher the $R^{2}$, the better the line fits the data.

Table 6. Geospatial data types, sources, and transformations used for analyses in baseline water-quality study in Muskingum River watershed, Ohio, 2015-16.

[NA, not applicable]

\begin{tabular}{|c|c|c|}
\hline Data type & Source & Data transformation \\
\hline $\begin{array}{l}\text { Oil and gas wells (both conven- } \\
\text { tional and shale) }\end{array}$ & $\begin{array}{l}\text { Ohio Department of Natural Resources, } \\
\text { Division of Oil \& Gas Resources, } \\
\text { 2017a; } \\
\text { Ohio Department of Natural Resources, } \\
\text { Division of Oil \& Gas Resources, 2017b }\end{array}$ & $\begin{array}{l}\text { Specific well types within the oil and gas database were } \\
\text { compiled to represent only producing oil and gas wells } \\
\text { (rather than dry holes or plugged wells). These well } \\
\text { types included (1) gas, (2) gas show (meaning some } \\
\text { gas), (3) gas with oil show, (4) gas and oil show, (5) oil, } \\
\text { (6) oil and gas, (7) oil show, and (8) oil with gas show. }\end{array}$ \\
\hline Wastewater treatment plants & $\begin{array}{l}\text { Ohio Department of Natural Resources, } \\
\text { Division of Oil \& Gas Resources, 2017c }\end{array}$ & NA \\
\hline $\begin{array}{l}\text { Land cover including forest, agri- } \\
\text { culture, and developed }\end{array}$ & Homer and others, 2015 & NA \\
\hline Municipal, county, and state roads & Ohio Department of Transportation, 2014 & NA \\
\hline $\begin{array}{l}\text { Townships with permits to spread } \\
\text { brine }\end{array}$ & $\begin{array}{l}\text { Kenny Brown, Ohio Department of Natu- } \\
\text { ral Resources, Division of Oil \& Gas } \\
\text { Resources, written commun., } 2017\end{array}$ & $\begin{array}{l}\text { Townships for Carroll County: Augusta, East, Lee, Loud- } \\
\text { on, Monroe, Orange, Perry, Rose, Union, Washington; } \\
\text { Harrison County: Cadiz, German, Green, Harrison, } \\
\text { Monroe, Nottingham, Washington; Guernsey County: } \\
\text { Londonderry; Monroe County: Malaga, Seneca. }\end{array}$ \\
\hline
\end{tabular}


Characteristics such as nonnormality, small sample sizes, and outliers often make environmental data unsuitable for common parametric analyses. For these reasons, nonparametric statistical analyses were used in Statistical Analysis System (SAS) JMP version 13.0.0 software (SAS Institute Inc., 2016) to draw inferences from the water-quality and geospatial data. For these nonparametric analyses, all concentrations less than the common reporting level for a constituent were assigned the same value that was less than all reported concentrations, so that ranks of values less than the highest reporting level were tied, yet less than the rank for the lowest measured concentration.

The Spearman's rank correlation coefficient is a nonparametric test that measures the strength and direction of monotonic association between two variables (Helsel and Hirsch, 1992). The Spearman's rank correlation coefficient is computed on the ranks of the data values instead of on the values themselves. The strength of the relation is denoted by rho - the closer rho is to +1 or -1 , the stronger the association. Positive values of rho signify a positive correlation and negative values of rho signifies a negative correlation. All correlations presented were statistically significant at a 95 -percent confidence level ( $p$-value $<0.05$ ). For purposes of this report, the strength of the correlation between two properties or constituents is defined as follows, based on the absolute value of rho: very-strong correlation $0.80-1.0$; strong correlation $0.60-0.79$; moderate correlation 0.40 to 0.59 ; and weak correlation $0.20-0.39$. The drainage areas of some sites were nested within the drainage basins of other sites. To ensure that the sample independence requirement for using Spearman's rank correlation coefficients was met, lake sites and gage sites below the lakes were excluded from tests. These sites were excluded because the upstream drainage basins of these sites contained drainage basins of other smaller sites, and the data from these smaller sites were used in the analyses.

The Wilcoxon rank-sum test was used to test differences among medians of constituent concentrations in different bin pairs such as coal-mine-impacted versus non-mine-impacted, samples with a brine component versus samples containing no brine, sites with and without injection wells in their drainage areas, and past versus current (2015-16) time periods (Helsel and Hirsch, 1992). All chi-square approximations for the Wilcoxon rank-sum test statistic used an alpha level of 0.05 to assess significance. The drainage areas of some sites were nested within the drainage basins of other sites. To ensure that the sample independence requirement for using the Wilcoxon rank-sum test was met, lake sites and gage sites below the lakes were excluded from tests. These sites were excluded because the upstream drainage basins of these sites contained drainage basins of other smaller sites, and the data from these smaller sites were used in the analyses.

An analysis of covariance was done to test the effects of streamflow, time (1960s, 1970s, 1980s, 2015-16), and the combined effects (cross product) of streamflow and time on chloride concentrations. An analysis of covariance was calculated using SAS JMP at a significance level set at alpha $=0.05$.

\section{Quality-Control Results}

Quality-control (QC) samples collected during sampling consisted of blanks and replicates. Blank samples were used to check for contamination during sample collection, processing, equipment cleaning, or analysis. Replicate samples were used to determine the reproducibility/variability in the collection and analysis of environmental samples. All QC samples were collected and processed according to protocols described in the USGS National Field Manual for the Collection of WaterQuality Data (USGS, variously dated).

To ensure sample integrity and final quality of data, QC samples (12 equipment blanks, 22 field blanks, and 19 replicate samples) were collected for all analytes except those measured or analyzed in the field (alkalinity, bicarbonate, carbonate, dissolved oxygen, $\mathrm{pH}$, specific conductance, sulfide, and temperature) and sent to the appropriate laboratory for analysis (Covert and others, 2018). The QC sample results were evaluated using the reporting levels originally specified by the laboratory, not the common reporting levels (table 4) subsequently used for statistical evaluation of environmental data.

\section{Equipment Blanks}

Prior to field sampling, 12 equipment blanks (Covert and others, 2018) were processed in a laboratory setting in February 2015. The equipment blanks were processed to confirm that sampling equipment, tubing, filters, and preservatives that would be used to collect and process the stream samples would not contribute appreciable amounts of the constituents of interest to the environmental samples.

Inorganic-free blank water was poured into each of the six churn splitters that would be used in the field to composite water collected across a stream cross section. Blank water aliquots to be analyzed for total phosphorus were collected from the churn spigot. Water samples to be analyzed for all dissolved inorganic and radiologic constituents were drawn from each churn using silicon tubing attached to a peristaltic pump, then passed through a 0.45 -micrometer $(\mu \mathrm{m})$ pore-size disposable capsule filter. Aliquots to be analyzed for total particulate carbon and nitrogen (TPCN) were filtered through one of the two $0.7-\mu \mathrm{m}$ pore-size glass-fiber filtering apparatuses to be used in the field. For the dissolved organic carbon equipment blank, volatile- and pesticide-free blank water (VPBW) was drawn from the blank water bottle through the silicon tubing by use of the peristaltic pump and then passed through a new $0.45-\mu \mathrm{m}$ pore-size disposable capsule filter. Equipment blank results for both pieces of equipment (churns and TPCN apparatuses) are listed as a single sample (Covert and others, 2018). For the VOC-sampler equipment blanks (Covert and others, 2018), each of the five VOC samplers to be used in the field were separately placed into a clean, stainless steel container and filled with VPBW until the vials in the sampler filled. All equipment blank samples for organic, inorganic, and 
radiologic constituents were preserved using the same procedures used for the environmental samples.

Multiple bottles of inorganic-free blank water and volatile- and pesticide-free blank water with the same lot numbers were used in the process of preparing the equipment blanks. When the bottles were opened, an aliquot of the unfiltered water was poured immediately into sample containers and stored at 4 degrees Celsius until results of equipment blank analyses were received. These samples are referred to as "source-solution blanks" (Francy and Shaffer, 2008). Sourcesolution blanks were analyzed only if a constituent was detected in an equipment blank.

Seven inorganic and organic equipment and sourcesolution blanks were sent to the NWQL for analysis (Covert and others, 2018). Six radiological equipment and sourcesolution blanks were sent to ALS Environmental for analysis (Covert and others, 2018). The VOC source-solution blank was not analyzed because VOCs were not detected in equipment blanks (Covert and others, 2018).

Concentrations of most constituents in the equipment blanks were less than the reporting levels with the following exceptions: (1) chloride was detected in one blank sample (churn 5) at the reporting level $(0.02 \mathrm{mg} / \mathrm{L})$; (2) manganese was detected in one blank sample (churn 3 ) at the reporting level (0.2 microgram per liter $[\mu \mathrm{g} / \mathrm{L}])$; (3) total particulate carbon was detected in one blank sample (churn 1) at a concentration of $0.57 \mathrm{mg} / \mathrm{L}$; (4) silica was detected in blank samples from all churns, with concentrations ranging from 0.11 to $0.25 \mathrm{mg} / \mathrm{L}$; (5) radium-226 was detected in blank samples from all churns, with concentrations ranging from 0.07 to 0.16 picocurie per liter $(\mathrm{pCi} / \mathrm{L})$; and (6) radium-228 was detected in blank samples from three of the six churns, with concentrations ranging from 0.23 to $0.35 \mathrm{pCi} / \mathrm{L}$ (Covert and others, 2018). The detected concentration of chloride in the equipment blank $(0.02 \mathrm{mg} / \mathrm{L})$ was at least 100 times less than the lowest chloride concentration in the environmental samples $(2.12 \mathrm{mg} / \mathrm{L})$, making the contribution by sample equipment negligible. The detected concentration of manganese in the equipment blank $(0.2 \mu \mathrm{g} / \mathrm{L})$ was about four times less than the lowest manganese concentration in the environmental samples $(0.78 \mu \mathrm{g} / \mathrm{L})$, making the contribution by sample equipment negligible. Following the detection of TPC in the equipment blank from churn splitter 1 and TPCN apparatus 2, these pieces of equipment were recleaned prior to field use. Subsequent field blanks collected from churn 1 and TPCN apparatus 2 (Seneca Fork below Senecaville Dam near Senecaville, Ohio [USGS station number 03141500] on October 26, 2015, and McGuire Creek near Leesville, Ohio [USGS station number 03120500] on March 15,2016) contained no detectable TPC (Covert and others, 2018).

Only silica, radium-226, and radium-228 were consistently detected in equipment blanks. Because silica was detected in the six churn (equipment) blanks but only $0.008 \mathrm{mg} / \mathrm{L}$ was detected in the source-solution blank, the contribution of silica by sampling equipment - most likely, the new silicon tubing - was indicated. Subsequent field blanks contained silica at concentrations of $<0.018$ to $0.08 \mathrm{mg} / \mathrm{L}$ (Covert and others, 2018), indicating that silica contribution to environmental samples from silicon tubing likely decreased with time. Regardless, the highest concentration of silica in any equipment blank $(0.25 \mathrm{mg} / \mathrm{L})$ was at least five times less than the lowest silica concentration in the environmental samples $(1.48 \mathrm{mg} / \mathrm{L})$, making the contribution by sample equipment negligible. No environmental concentrations of silica were censored based on QC findings.

The presence of radium-226 and radium-228 in the equipment blanks is indicative of the ubiquitous nature of these naturally occurring radionuclides. Both constituents also were detected in the source-solution blank (Covert and others, 2018) - in the case of radium-228, at a higher concentration $(0.64 \mathrm{pCi} / \mathrm{L})$ than was detected in the equipment blanks. Concentrations present in source solution and equipment blanks did not seem to indicate contamination of equipment or poor sample-handling technique. Rather, concentrations were within the range of normal background levels (Ann Mullin, NWQL Radiochemistry Unit Chemist, written commun., 2017). Radium reporting level decisions based on QC data are discussed further in the "Field Blanks" section.

\section{Field Blanks}

To identify contamination from equipment, supplies, ambient environmental conditions, and sample handling techniques (Francy and Shaffer, 2008), field blank samples were collected for 52 analytes (Covert and others, 2018). Blanks were not collected for alkalinity, bicarbonate, carbonate, dissolved oxygen, $\mathrm{pH}$, specific conductance, sulfide, or suspended sediment. Ten blank samples were collected and processed through (1) a churn splitter for major ion, trace metal, nutrient, dissolved organic carbon, and radionuclide analytes and (2) a sampler for VOCs. The field blanks were collected using the same procedures described for the equipment blanks except that the samples were processed streamside rather than in a laboratory. Field blanks were collected at a sampling location prior to the sampling equipment and churn splitter being used to collect the environmental sample.

Bias was evaluated by comparing the range of blank results to the range of all environmental results and was calculated as the percentage of detections in environmental samples that were less than the maximum blank value (ideally, zero percent). Field blanks contained detectable concentrations of aluminum, ammonia, arsenic, chloride, lithium, magnesium, silica, styrene, total particulate carbon, total dissolved nitrogen, radium-226, and radium-228 (Covert and others, 2018). For ammonia, arsenic, chloride, lithium, magnesium, silica, total particulate carbon, and total dissolved nitrogen, the percentage of environmental samples with detected concentrations less than the maximum field blank concentration ranged from 0 to 10.9 percent.

For aluminum and styrene, however, detected concentrations were less than the maximum blank concentration 
for most of the environmental samples (65.1 and 84 percent, respectively). Aluminum foil was used to cover and protect some of the field equipment from contaminants and might have increased aluminum concentrations in the environmental samples. Styrene, a component of motor vehicle gasoline (Zogorski and others, 2006), can potentially be present in exhaust fumes in the ambient air during sample collection, processing, and shipment. To eliminate positive bias from potential systematic contamination in the environmental samples, the environmental results for aluminum and styrene were censored at three times the average detectable blank concentration -20.8 and $0.31 \mu \mathrm{g} / \mathrm{L}$, respectively (table 4 ). Censoring the data in this way was deemed to be conservative and resulted in 25 of 177 samples (14 percent) having aluminum concentrations higher than the new reporting level. Styrene detections were not higher than the new reporting level.

Additionally, some field blanks for aluminum, ammonia, and styrene contained concentrations that were near or higher than the associated environmental sample (although for ammonia this was not deemed to be a systematic problem with the dataset). In these instances of concentrations near or higher than the associated environmental sample, the tabulated blank-pair results were colored red and bolded in (Covert and others, 2018), and the environmental data were given a remark code of "V" (meaning "value affected by contamination") and a value-qualifier code of "e" (meaning "see field comments for this result") in the USGS NWIS database (USGS, 2017a).

Field blank and environmental sample pairs for radium-226 and radium-228 were evaluated using the formula for normalized absolute difference (McCurdy and others, 2008, p. 15), which considers the sample results and associated uncertainties (plus or minus values) to determine whether the pairs are statistically the same or different at a 95-percent confidence level. Of the 10 -field blank/environmental sample pairs analyzed for radium-226, 8 were not determined to be statistically different, as designated by bolded blue text in the tabulated results (Covert and others, 2018). All the radium-228 field blank/environmental sample pairs were statistically the same. The great degree of overlap in radiological blanks and environmental samples, however, was not viewed as contamination from equipment or sample-handling technique; rather, counts detected in blanks were within the range of normal, background levels (Ann Mullin, NWQL Radiochemistry Unit Chemist, written commun., 2017). To evaluate samples exceeding background levels of radium-226 and radium-228 (for those samples that did not have an associated field blank), the environmental results for these constituents were compared to the highest blank count for each constituent-radium-226 count of $0.18+0.053 \mathrm{pCi} / \mathrm{L}$ (field blank) and radium-228 count of $0.64+0.13 \mathrm{pCi} / \mathrm{L}$ (source-solution blank) - using normalized absolute differences (McCurdy and others, 2008). Radium-226 counts in only two environmental samples were different from the highest field blank count at a statistically significant level. Similarly, the radium-228 count for only one environmental sample was different from the highest source-solution blank count at a statistically significant level. For the purposes of this report, reporting levels for radium-226 and radium-228 were increased to 0.51 and $1.2 \mathrm{pCi} / \mathrm{L}$ (table 4), respectively, to distinguish samples with counts at or higher than these levels from samples with counts statistically the same as blanks.

\section{Analytical Bias}

To determine and track the degree of bias and variability (or uncertainty) associated with the measured values of chemical concentration with time, the USGS Quality Systems Branch (QSB) operates independent, external, blind sample projects for inorganic, nutrient (Inorganic Blind Sample Project), and organic (Organic Blind Sample Project) constituents (USGS, 2017b). Through the projects, "blind" QC samples are submitted for analysis, meaning that concentration levels in the samples are unknown to the analyst. Blind QC samples are either blanks or contain selected inorganic, organic, and nutrient constituents at various concentrations and are presented as routine environmental samples. Tables and charts available from the QSB website (https://bqs.usgs.gov) indicate how closely the NWQL analytical results approximate the target value of the blind QC samples. Metrics obtained from the QSB for dissolved aluminum (parameter code 01106, method code PLM43) indicated false positive rates of 8 and 11 percent for 2015 and 2016, respectively, in blind blanks sent to the lab. Most (78 percent) of the false positive concentrations were less than $11 \mu \mathrm{g} / \mathrm{L}$. Thus, analytical bias could have caused some of the aluminum detections in field blanks. This analytical bias further validates the decision to increase the reporting level for aluminum to $20.8 \mu \mathrm{g} / \mathrm{L}$ for the purposes of this report. Furthermore, control charts obtained from the QSB website indicated a consistently positive deviation in measured aluminum concentrations from the known concentration of the blind samples (the median concentrations of each constituent in the standard reference samples [https://bqs.usgs.gov/srs] used to make the double-blind QC samples) during the time that study samples were being analyzed for inorganics (April 13, 2015, through August 4, 2016). This deviation suggests that aluminum results for this study might exhibit a similar positive bias.

Blind blank results for styrene (parameter code 77128, method code GCM66) included no false positives or false negatives for the period that study samples were being analyzed for VOCs (April 13, 2015, through October 31, 2016) (https://bqs.usgs.gov/OBSP/False_pos_neg_March17.html). These results indicated that the source of styrene contamination in the field blanks for this study was not from the laboratory but rather was introduced in the field.

\section{Replicate Samples}

To identify or determine variability (random measurement error) in the collection and analysis of environmental samples, replicate samples were collected for 52 analytes (Covert and others, 2018). Replicates were not collected for alkalinity, bicarbonate, carbonate, dissolved oxygen, $\mathrm{pH}$, 
specific conductance, or sulfide. Ten sequential VOC replicate samples were collected with the same VOC sampler and methodology as the environmental samples. Nine additional (non-VOC) replicate samples were collected and processed through a churn splitter. These non-VOC replicate samples were collected with the same sampling equipment as the environmental samples but composited in different churn splitters-putting samples from alternating transect passes into one of two churn splitters. Variability was evaluated in two ways: (1) variability of detections for replicate sets and (2) variability of concentrations.

\section{Variability of Detections}

Variability of detections was assessed by calculating the mean percentage detection of a constituent and the percentage of inconsistent replicate sets (sets that contain one detection and one nondetection) (table 7). The mean detection rate of an analyte was calculated as the average of the percentage detections for the replicate sets within a given concentration range (Mueller and others, 2015). The percentage detections in a single replicate set was 100 percent when both values in a replicate set were detections and 50 percent when a replicate set contained detections and nondetections. Replicate sets with two nondetections were excluded from the calculation of mean percentage detection values. The percentage of replicate sets with inconsistent detections was calculated as the number of replicate sets with inconsistent detections divided by the total number of replicate sets minus the number of sets with consistent nondetections (both results less than the reporting level) (Mueller and others, 2015).

Variability of constituent detections was a function of concentration, and estimates of variability were developed for discrete ranges of concentration. The mean percentage detection and the percentage of inconsistent replicate sets were calculated separately for three ranges of concentration that are a function of the reporting level as follows: (1) less than the reporting level, (2) the reporting level to 10 times the reporting level, and (3) higher than 10 times the reporting level. For convenience in the text and for relative comparisons, the three ranges of concentration are referred to as "low," "medium," and "high," respectively.

A mean percentage detection of 75 percent or less and a percentage of inconsistent replicate sets of 50 percent or higher was used in this assessment to indicate that variability of detection was high (Martin, 2001). Both approaches to calculating variability of detection indicated high variability at concentrations less than the reporting level; variability decreased with increasing concentrations. High variability of detection was determined in 7 of 14 (50 percent) constituents in the low range, 1 of 18 (6 percent) in the medium range, and 0 of 21 ( 0 percent) in the high range (table 7). Constituents with a high variability of detection in the low range included iron, nitrate plus nitrite, particulate nitrogen, 1,2,3-trimethylbenzene, 1,2,4-trimethyl-benzene, acetone, and benzene (table 7). Only the variability of detection in the medium range was considered high for zinc. The zinc concentration for the environmental sample at Seneca Fork above Senecaville Lake, Ohio, on August 26, 2015, was $17.3 \mu \mathrm{g} / \mathrm{L}$, whereas the replicate result was a nondetection.

In general, the higher variability of detection for analyte concentrations near the reporting level than for those at medium and high concentrations was attributed to variability in the analytical method and not to sample contamination, which the use of reporting levels is intended to prevent. Most instances of high variability of detection were calculated with a maximum of only one replicate set (two for iron).

\section{Variability of Concentrations}

The variability of concentrations was assessed using relative percent differences (RPD) for replicate sets having two detected values (Covert and others, 2018). The RPD in concentrations between replicate paired samples (for example, $\mathrm{c} 1$ and $\mathrm{c} 2)$ were calculated as $[100 *(\mathrm{c} 1-\mathrm{c} 2) /((\mathrm{c} 1+\mathrm{c} 2) / 2)]$. A criterion of 20 percent difference or less was considered acceptable. The RPD could not be calculated for seven inconsistent replicate sets (sets that contain one detection and one nondetection). Median RPD and range of differences in concentration for replicate sets were computed for each constituent (Covert and others, 2018).

For major ions, all RPDs were less than 20 percent, and the median RPD ranged from 0 to 3.5 percent. For metals and trace elements, the median RPDs for seven of nine constituents were less than 20 percent and ranged from 0.5 to 19.7 percent. The median RPDs for aluminum and iron were 44.3 and 31.5, respectively. The RPD for aluminum replicates ranged from 0 to 72.1 percent, and the differences between the environmental and replicate concentrations ranged from 0 to $8.3 \mu \mathrm{g} / \mathrm{L}$. (Note that RPDs for aluminum were calculated prior to raising the reporting level for aluminum to eliminate bias indicated in field blanks. All replicate results were less than the raised reporting level of $20.8 \mu \mathrm{g} / \mathrm{L}$.) RPDs for iron replicate values ranged from 6.6 to 138.2 percent, and the differences between the environmental and replicate concentrations ranged from 3.4 to $133.2 \mu \mathrm{g} / \mathrm{L}$. Although the median RPD of 19.7 percent for lithium was less than the 20 percent criterion, the individual RPDs ranged from 0.4 to 102 percent and four individual RPDs were more than 20 percent. For nutrients, all median RPDs were less than 20 percent and ranged from 0 to 9.9 percent. For turbidity and suspended sediment, both median RPDs were less than 20 percent and were 5.1 to 17.8 percent, respectively.

The variability of replicate pairs for radium-226 and radium-228 was evaluated using the formula for normalized absolute difference (McCurdy and others, 2008, p. 15), which considers the sample results and associated uncertainties (plus or minus values) to determine whether the pairs are statistically the same or different at a 95-percent confidence level. Replicate pairs can be determined to be statistically the same, even when one sample is deemed a detection and the other sample is deemed a nondetection (Ann Mullin, NWQL, 
Table 7. Variability of detections in field replicates for baseline water-quality study in Muskingum River watershed, Ohio, 2015-16.

[Consistent detection means that the constituent concentration was greater than the reporting level in both samples in a replicate set, or it was not detected in either sample. Inconsistent detections means that the constituent concentration was greater than the reporting level for one sample in a replicate set, but not the other sample. The mean detection rate of an analyte was calculated as the average of the percentage detections for the replicate sets within a given concentration range. The percentage detections in a single replicate set was 100 percent if both values in a replicate set were detections and 50 percent if a replicate set contained both detections and nondetections. The percentage of replicate sets with inconsistent detections was calculated as the number of replicate sets with inconsistent detections divided by the total number of replicate sets minus the number of sets with consistent non-detections (both results less than the reporting level) (Mueller and others, 2015). The variability of radium-226 and radium-228 measurements were evaluated using a different method and are not shown in this table. $<$, less than; mg/L, milligrams per liter; $\mu \mathrm{g} / \mathrm{L}$, micrograms per liter; $\mathrm{N}$, nitrogen; $\geq$, greater than or equal to; $\mathrm{P}$, phosphorus; $\mathrm{SiO}{ }_{2}$, silica]

\begin{tabular}{|c|c|c|c|c|c|c|}
\hline \multirow[b]{2}{*}{ Analyte } & \multirow[b]{2}{*}{$\begin{array}{l}\text { Reporting } \\
\text { level }\end{array}$} & \multicolumn{3}{|c|}{ Number of replicate sets with } & \multirow{2}{*}{$\begin{array}{c}\text { Mean } \\
\text { detection } \\
\text { rate } \\
\text { (percent) }\end{array}$} & \multirow{2}{*}{$\begin{array}{c}\text { Replicate sets } \\
\text { with inconsistent } \\
\text { detections } \\
\text { (percent) }\end{array}$} \\
\hline & & $\begin{array}{l}\text { At least one } \\
\text { detection }\end{array}$ & $\begin{array}{l}\text { Consistent } \\
\text { detections }\end{array}$ & $\begin{array}{l}\text { Inconsistent } \\
\text { detections }\end{array}$ & & \\
\hline \multicolumn{7}{|c|}{ (Low) mean concentration of the replicate sets: $<$ reporting level } \\
\hline Bromide (mg/L) & 0.05 & 5 & 3 & 2 & 80 & 40 \\
\hline Aluminum $(\mu \mathrm{g} / \mathrm{L})$ & 18 & 8 & 7 & 1 & 93.75 & 12.5 \\
\hline Arsenic $(\mu \mathrm{g} / \mathrm{L})$ & 0.6 & 7 & 7 & 0 & 100 & 0 \\
\hline $\operatorname{Iron}(\mu \mathrm{g} / \mathrm{L})$ & 4 & 2 & 0 & 2 & 50 & 100 \\
\hline Nitrogen (nitrate plus nitrite) (mg/L as N) & 0.04 & 1 & 0 & 1 & 50 & 100 \\
\hline Total particulate nitrogen $(\mathrm{mg} / \mathrm{L})$ & 0.03 & 1 & 0 & 1 & 50 & 100 \\
\hline 1,2,3-Trimethyl-benzene $(\mu \mathrm{g} / \mathrm{L})$ & 0.06 & 1 & 0 & 1 & 50 & 100 \\
\hline 1,2,4-Trimethyl-benzene $(\mu \mathrm{g} / \mathrm{L})$ & 0.032 & 1 & 0 & 1 & 50 & 100 \\
\hline Acetone $(\mu \mathrm{g} / \mathrm{L})$ & 3.4 & 1 & 0 & 1 & 50 & 100 \\
\hline Benzene $(\mu \mathrm{g} / \mathrm{L})$ & 0.026 & 1 & 0 & 1 & 50 & 100 \\
\hline m-Xylene plus p-xylene $(\mu \mathrm{g} / \mathrm{L})$ & 0.08 & 1 & 1 & 0 & 100 & 0 \\
\hline o-Xylene $(\mu \mathrm{g} / \mathrm{L})$ & 0.032 & 1 & 1 & 0 & 100 & 0 \\
\hline Styrene $(\mu \mathrm{g} / \mathrm{L})$ & 0.042 & 4 & 3 & 1 & 87.5 & 25 \\
\hline Toluene $(\mu \mathrm{g} / \mathrm{L})$ & 0.03 & 1 & 1 & 0 & 100 & 0 \\
\hline \multicolumn{7}{|c|}{ (Medium) mean concentration of the replicate sets: $\geq$ reporting level and $<10$ times the reporting level } \\
\hline Suspended sediment $(\mathrm{mg} / \mathrm{L})$ & 1 & 4 & 4 & 0 & 100 & 0 \\
\hline Total dissolved solids (mg/L) & 20 & 3 & 3 & 0 & 100 & 0 \\
\hline Bromide $(\mathrm{mg} / \mathrm{L})$ & 0.05 & 1 & 1 & 0 & 100 & 0 \\
\hline Fluoride (mg/L) & 0.01 & 2 & 2 & 0 & 100 & 0 \\
\hline Arsenic $(\mu \mathrm{g} / \mathrm{L})$ & 0.6 & 1 & 1 & 0 & 100 & 0 \\
\hline Boron $(\mu \mathrm{g} / \mathrm{L})$ & 2 & 1 & 1 & 0 & 100 & 0 \\
\hline Iron $(\mu \mathrm{g} / \mathrm{L})$ & 4 & 1 & 1 & 0 & 100 & 0 \\
\hline Lithium $(\mu \mathrm{g} / \mathrm{L})$ & 0.22 & 6 & 6 & 0 & 100 & 0 \\
\hline $\operatorname{Zinc}(\mu \mathrm{g} / \mathrm{L})$ & 1.9 & 1 & 0 & 1 & 50 & 100 \\
\hline Ammonia $(\mathrm{mg} / \mathrm{L}$ as $\mathrm{N})$ & 0.01 & 7 & 7 & 0 & 100 & 0 \\
\hline Nitrogen (nitrate plus nitrite) (mg/L as N) & 0.04 & 4 & 4 & 0 & 100 & 0 \\
\hline Orthophosphate $(\mathrm{mg} / \mathrm{L}$ as $\mathrm{P})$ & 0.004 & 5 & 5 & 0 & 100 & 0 \\
\hline Total particulate nitrogen $(\mathrm{mg} / \mathrm{L})$ & 0.03 & 7 & 7 & 0 & 100 & 0 \\
\hline Phosphorus (mg/L as P) & 0.004 & 7 & 7 & 0 & 100 & 0 \\
\hline Total dissolved nitrogen $(\mathrm{mg} / \mathrm{L})$ & 0.05 & 7 & 7 & 0 & 100 & 0 \\
\hline Total particulate carbon $(\mathrm{mg} / \mathrm{L})$ & 0.05 & 4 & 4 & 0 & 100 & 0 \\
\hline Dissolved organic carbon (mg/L) & 0.23 & 3 & 3 & 0 & 100 & 0 \\
\hline Styrene $(\mu \mathrm{g} / \mathrm{L})$ & 0.042 & 1 & 1 & 0 & 100 & 0 \\
\hline
\end{tabular}


Table 7. Variability of detections in field replicates for baseline water-quality study in Muskingum River watershed, Ohio, 2015-16. - Continued

[Consistent detection means that the constituent concentration was greater than the reporting level in both samples in a replicate set, or it was not detected in either sample. Inconsistent detections means that the constituent concentration was greater than the reporting level for one sample in a replicate set, but not the other sample. The mean detection rate of an analyte was calculated as the average of the percentage detections for the replicate sets within a given concentration range. The percentage detections in a single replicate set was 100 percent if both values in a replicate set were detections and 50 percent if a replicate set contained both detections and nondetections. The percentage of replicate sets with inconsistent detections was calculated as the number of replicate sets with inconsistent detections divided by the total number of replicate sets minus the number of sets with consistent non-detections (both results less than the reporting level) (Mueller and others, 2015). The variability of radium-226 and radium-228 measurements were evaluated using a different method and are not shown in this table. $<$, less than; mg/L, milligrams per liter; $\mu \mathrm{g} / \mathrm{L}$, micrograms per liter; $\mathrm{N}$, nitrogen; $\geq$, greater than or equal to; $\mathrm{P}$, phosphorus; SiO ${ }_{2}$, silica]

\begin{tabular}{|c|c|c|c|c|c|c|}
\hline \multirow[b]{2}{*}{ Analyte } & \multirow{2}{*}{$\begin{array}{l}\text { Reporting } \\
\text { level }\end{array}$} & \multicolumn{3}{|c|}{ Number of replicate sets with } & \multirow{2}{*}{$\begin{array}{l}\text { Mean } \\
\text { detection } \\
\text { rate } \\
\text { (percent) }\end{array}$} & \multirow{2}{*}{$\begin{array}{l}\text { Replicate sets } \\
\text { with inconsistent } \\
\text { detections } \\
\text { (percent) }\end{array}$} \\
\hline & & $\begin{array}{l}\text { At least one } \\
\text { detection }\end{array}$ & $\begin{array}{l}\text { Consistent } \\
\text { detections }\end{array}$ & $\begin{array}{l}\text { Inconsistent } \\
\text { detections }\end{array}$ & & \\
\hline \multicolumn{7}{|c|}{ (High) mean concentration of the replicate sets: $\geq 10$ times the reporting level } \\
\hline Suspended sediment (mg/L) & 1 & 5 & 5 & 0 & 100 & 0 \\
\hline Total dissolved solids (mg/L) & 20 & 6 & 6 & 0 & 100 & 0 \\
\hline Magnesium (mg/L) & 0.011 & 9 & 9 & 0 & 100 & 0 \\
\hline Sodium (mg/L) & 0.06 & 9 & 9 & 0 & 100 & 0 \\
\hline Potassium (mg/L) & 0.03 & 9 & 9 & 0 & 100 & 0 \\
\hline Chloride (mg/L) & 0.02 & 9 & 9 & 0 & 100 & 0 \\
\hline $\operatorname{Barium}(\mu \mathrm{g} / \mathrm{L})$ & 0.25 & 9 & 9 & 0 & 100 & 0 \\
\hline Boron $(\mu \mathrm{g} / \mathrm{L})$ & 2 & 8 & 8 & 0 & 100 & 0 \\
\hline Iron $(\mu \mathrm{g} / \mathrm{L})$ & 4 & 4 & 4 & 0 & 100 & 0 \\
\hline Lithium $(\mu \mathrm{g} / \mathrm{L})$ & 0.22 & 3 & 3 & 0 & 100 & 0 \\
\hline Manganese ( $\mu \mathrm{g} / \mathrm{L})$ & 0.2 & 9 & 9 & 0 & 100 & 0 \\
\hline Strontium $(\mu \mathrm{g} / \mathrm{L})$ & 0.2 & 9 & 9 & 0 & 100 & 0 \\
\hline Nitrogen (nitrate plus nitrite) (mg/L as $\mathrm{N}$ ) & 0.04 & 1 & 1 & 0 & 100 & 0 \\
\hline Phosphorus (mg/L as P) & 0.004 & 2 & 2 & 0 & 100 & 0 \\
\hline Total dissolved nitrogen (mg/L) & 0.05 & 2 & 2 & 0 & 100 & 0 \\
\hline
\end{tabular}


written commun., 2017). For radium-226, eight of nine replicate pairs were statistically the same at a 95-percent confidence level as calculated using normalized absolute percent difference (Covert and others, 2018; samples designated by black text). For radium-228, seven of nine replicate pairs were statistically the same. This result indicates good reproducibility, even at the low concentrations detected in the study samples.

\section{Data Treatment Based on Quality-Control Results}

In summary, reporting levels were raised for the purposes of this report on two constituents - aluminum and styrene- to eliminate systematic positive bias in environmental samples caused by sample collection, sample handling, or sample analysis. Similarly, reporting levels for radium-226 and radium-228 were raised to distinguish samples with natural background counts from samples with counts higher than natural background levels. The reporting levels were raised prior to graphical plotting or statistical analysis of data.

Sampling and analytical variability were evaluated using replicate analyses. In subsequent sections of this report, when statistical analysis of water-quality data identified statistically significant differences between groups of data (such as sites impacted by mine drainage versus non-mine-impacted sites, samples containing a component of brine versus samples without a brine component, and samples from sites with injection wells in the drainage basin versus samples without injection wells in the drainage basin), the authors assessed if the observed difference in median concentrations between groups was higher than the maximum difference in concentration between QC replicate pair samples (Covert and others, 2018). Notations on boxplots of grouped data indicate when apparent differences between groups may be the result of sampling and analytical variability rather than actual environmental differences between groups.

\section{Baseline Water Quality}

This report documents the occurrences and concentrations from April 2015 to May 2016 of a suite of constituents, many of which may be present at elevated concentrations in sediment released by construction of well pads, flowback and produced waters associated with oil and gas development, or coal-mine drainage. As part of the record of baseline conditions, water-quality data were used to assess (1) water types based on major ion chemistry; (2) sources of salinity to streams; (3) seasonal and spatial variations in water quality associated with natural drainage basin characteristics, in-lake processes, or unknown factors; (4) potential for stream water to adversely affect aquatic life; (5) relations between water chemistry and measures of oil and gas development; and
(6) comparison of study results to historical (1960s-1980s) chloride concentrations.

Summary statistics are presented for physical waterquality properties and chemical analyses for streams, lakes, and the gage sites below the dams (table 8). Complete analytical results are available online from the USGS NWIS database (USGS, 2017a).

\section{Hydrologic Conditions and Changes in Specific Conductance Captured by Sampling Events}

Six samples were collected at each site to characterize water chemistry during a range of hydrologic conditions. Usually in this type of study, the conditions captured by the sampling events are compared to the range of hydrologic conditions that occurred historically in the area to provide context. However, the only long-term historical streamflow data available in the study area are from the gages below the dams, where streamflow is artificially controlled. Stream stage and specific conductance data do exist, however, at each of the 14 water-quality gages installed on tributaries to the lakes in 2015. Thus, to assess the range of conditions that occurred at a site compared to the amount of variation represented by the sampling events, the six discrete values of stream stage and specific conductance at each site were compared to hourly measurements of stream stage and specific conductance at each of the 14 water-quality gages (figs. $1-1 A$ through $1-1 N$ ). Discrete and continuous specific conductance readings taken at the same time do not always match exactly. Discrete specific conductance values were the median of at least three readings taken across the stream cross section, whereas continuous specific conductance readings were taken at a single point in the stream. Specific conductance is an indication of the ionic strength of water, which is related to the concentration and charge of all ions in solution (Hem, 1985). Together, stream stage and specific conductance provide clues about the hydrologic conditions sampled - whether a sample is composed primarily of groundwater discharge or runoff. Also, the amount of variation in specific conductance captured combined with visual inspection of the hydrographs (figs. 1-1A through $1-1 N$ ) provides a qualitative indicator of stream chemistry and indicates if the samples adequately represent the gradient of major ion concentrations likely to occur at a site.

As an example, measurements made at Unnamed tributary near Dellroy, Ohio (in the Atwood Lake drainage basin) are shown in figure 1-1A. This plot is typical of patterns of specific conductance and stream stage indicated at almost all sites. Specific conductance was generally high during dry, low stream stage periods, but decreased during rainfall events because of the influx of runoff with low specific conductance, as indicated by sudden decreases in specific conductance corresponding to peaks in stream stage. This pattern also occurs because groundwater contains minerals dissolved from the aquifer matrix that cause the specific conductance to be elevated relative to that of precipitation, and base flow 


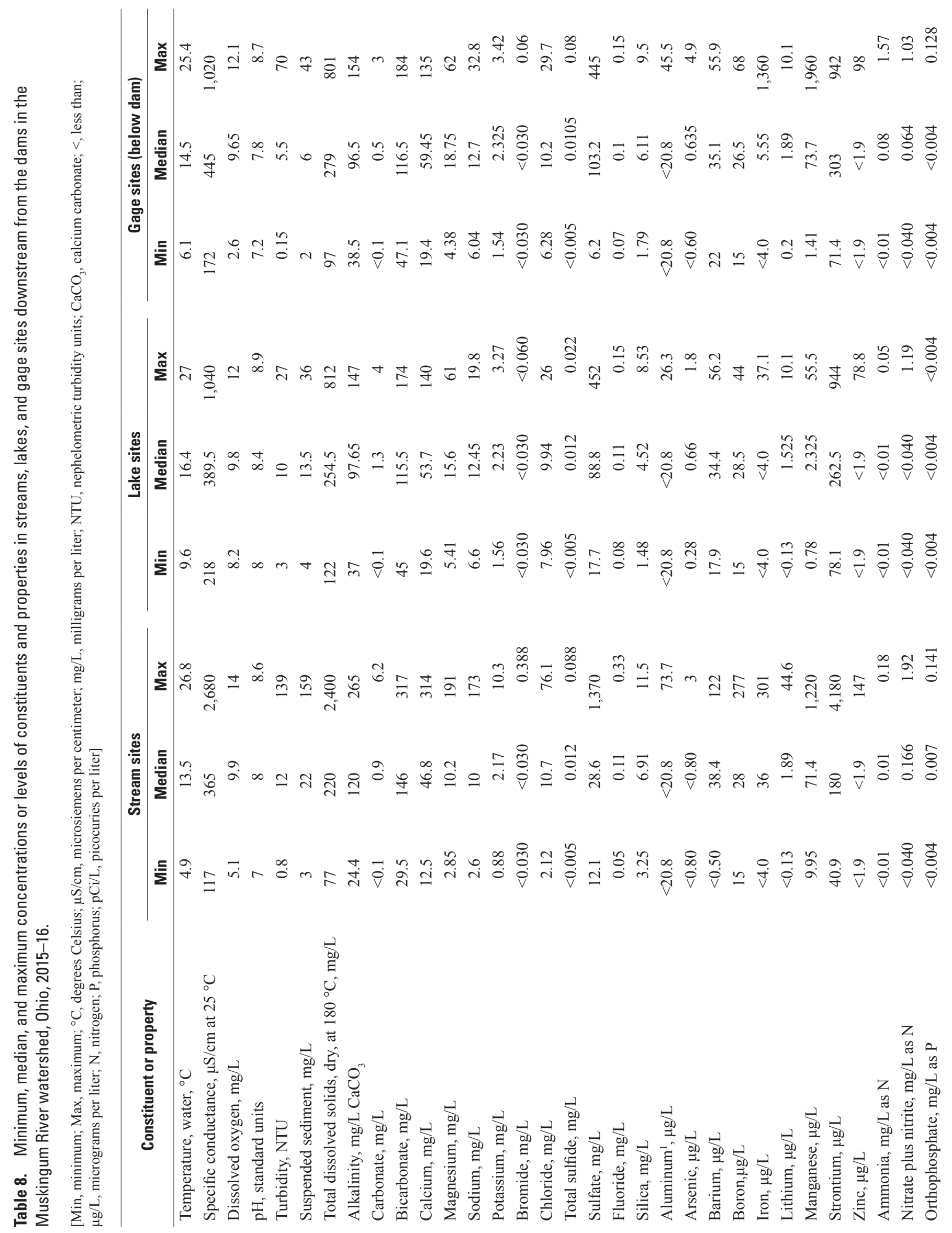




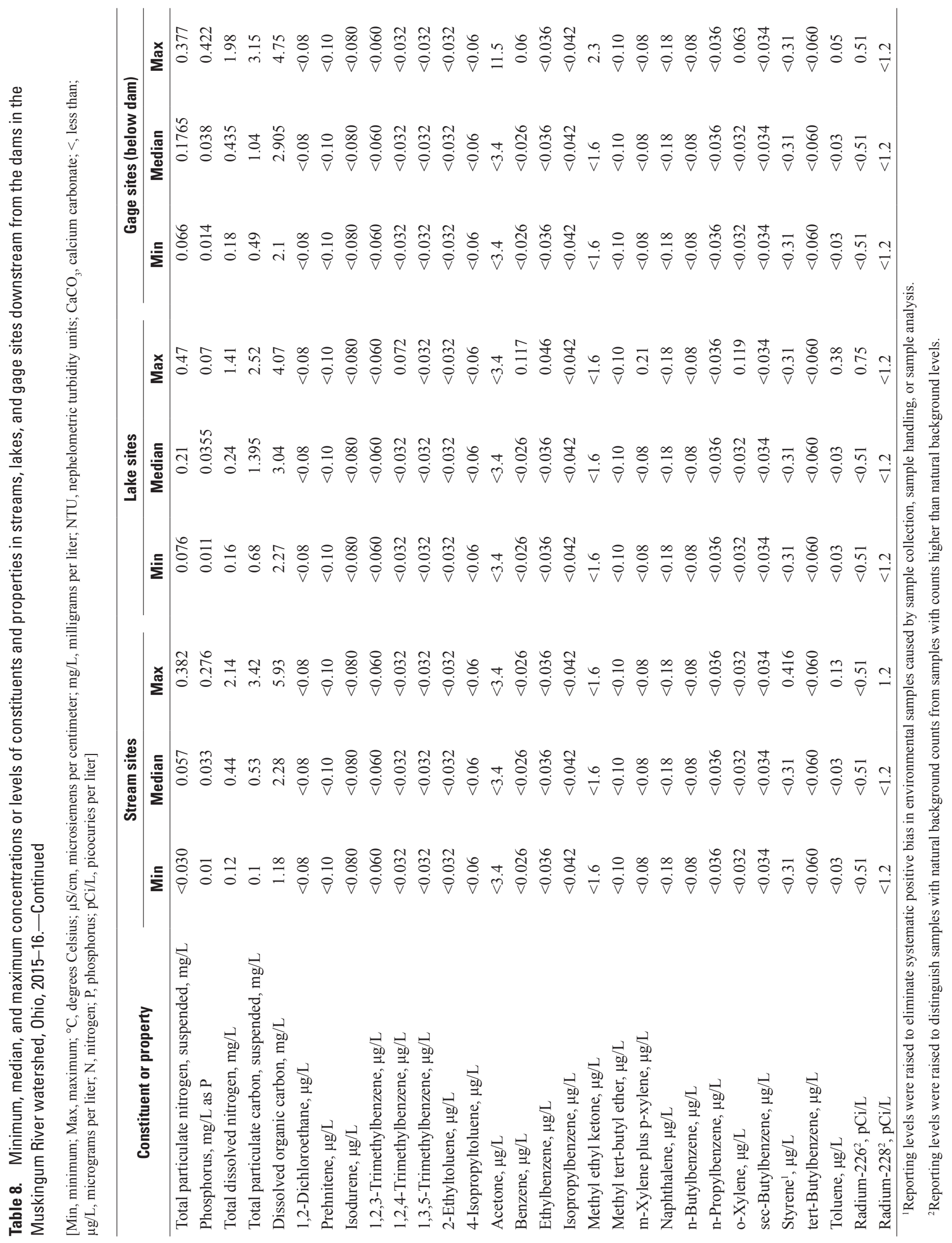


(groundwater discharge to streams) makes up a larger part of the streamflow during dry periods.

Stream stage and specific conductance also can be affected by seasonality. In winter, after vegetation has been killed by frost, proportionally less precipitation is lost to evaporation and plant uptake, and more precipitation reaches streams as runoff than during late spring and summer. This result is evidenced by generally higher base flow during the winter and early spring (mid-December through late April) and a higher rise in stream stage after winter precipitation events compared to the rise in stream stage that occurs after a summer precipitation event. The result is that specific conductance tends to be less during the winter and starts to rise again in May as temperatures rise, triggering increases in evaporation and plant growth with its attendant transpiration. This seasonal trend in specific conductance is muted at water-quality gage sites in the Senecaville Lake drainage basin (figs. 1-1L through $1-1 N$ ), and flow in this drainage basin is flashier (more sudden and higher spikes in stream stage) than in the lake drainage basins to the north.

At each of the 14 gages, the range of specific conductance measured during the 6 sampling rounds was divided by the range of specific conductance measured hourly from April 1, 2015, through June 30, 2016, to determine the percentage of total variation that was captured by the sampling events (table 9). Maximum and minimum specific conductance measured at the site always were recorded at the gage - not by a discrete measurement. Water-quality sampling captured from 18.6 to 71.3 percent of total variation in specific conductance at the sites. A lesser average percentage variation was captured by samples at sites in Piedmont and Senecaville drainage basins relative to sites in other lake drainage basins (table 9).

The range of stream stage measured during the six discrete sampling rounds was divided by the total observed range in stream stage to determine the percentage variation in stream stage that was captured by the sampling events. Total range of stream stage was the maximum value (always observed at the gage) minus the minimum value (sometimes a gage reading, sometimes a discrete reading). Water-quality sampling captured from 13.2 to 51.0 percent of total variation in stream stage at the sites (table 9). Sampling generally occurred during low flows (periods of higher groundwater contribution) rather than during runoff events (periods of high stream stage, decreased specific conductance), although a runoff event in March 2016 was captured at some sampling sites (figs. 1-1A through $1-1 E$ and figs. 1-1G through 1-1I).

The 14 gages that continuously record water quality captured sudden, unusual spikes in specific conductance that seem to represent "incidents" - releases of water with different chemical characteristics relative to that usually present in the stream. These incidents were not captured by the waterquality samples. An example of such an incident was recorded at Willow Run near Dellroy, Ohio, in July 2015 (fig. 1-1B). Although rise in stream stage on July 6 coincided with a drop in specific conductance, as expected, the next, lower rise in stream stage on July 14 coincided with an increase in specific conductance of 166 microsiemens per centimeter at 25 degrees Celsius $(\mu \mathrm{S} / \mathrm{cm})$ that lasted for 9 days (fig. $1-1 B)$. A similar, sudden and unusual increase in specific conductance by more than $400 \mu \mathrm{S} / \mathrm{cm}$ occurred at McGuire Creek above Leesville Lake, Ohio, between June 27 and July 11, 2015 (fig. 1-1F), concurrent with a rise in stream stage (although this time the specific conductance increase consisted of three, closely spaced pulses). The discrete water-quality sampling rounds did not capture either of these unusual specific conductance incidents (resulting in a particularly low score for percentage of specific conductance variation captured by sampling at McGuire Creek above Leesville Lake, Ohio [table 9]). However, the timing of discrete samples bracketed the incidents.

\section{Water Types Based on Major Ions}

Differences in the chemical composition of water at different sampling sites can be examined by use of trilinear diagrams (fig. 8). This type of diagram is constructed by converting concentrations of major cations and anions to milliequivalents per liter and then plotting relative percentages of the major cations on the lower left triangle and major anions on the lower right triangle (Hem, 1985). Each corner on the triangles represents 100 percent of a particular type (or types) of ions. The cation and anion compositions are then projected along lines parallel to the outer edges of the equilateral triangles until the cation and anion projections intersect on the upper, diamond-shaped diagram. Plotting of the data in this way allows concentrations of multiple cations and anions to be examined at once. In addition to plotting data for samples from the 30 sites, data for brines originating from oil and gasdrilling activities in Ohio (Blondes and others, 2017; hereafter referred to as "Ohio brines") were plotted on the trilinear diagram as points of reference, as were water samples affected by road salt. The brines were from conventional wells-no analyses of Marcellus Shale or Utica/Point Pleasant formation brines were available from Ohio. The water samples affected by road salt included a sample of road salt runoff from beneath a bridge in Western Springs, Illinois (sample RS-2 in table 2 of Panno and others [2005]) and samples of groundwater collected from monitoring wells at a salt-storage facility in Valparaiso, Indiana (wells TW-2, TW-94D, TW-94E, MW-3, MW-4, MW-5, and MW-7 in table 1 of Risch and Robinson [2000]). The surface-water samples that plot close to the Ohio brines or road salt affected samples have a higher proportion of sodium and chloride ions than other stream samples and might contain a component of road salt or oil-field brine.

The study samples can be divided into the following three distinct groups: calcium-bicarbonate-type waters that are dominated by the bicarbonate anion, calcium-magnesiumsulfate-type waters that are dominated by the sulfate anion (hereafter referred to as "sulfate-type waters"), and mixed bicarbonate-chloride-type waters. Most of the samples were calcium-bicarbonate waters. Samples from all Piedmont Lake sites, most Tappan Lake sites (Standingstone Fork above 


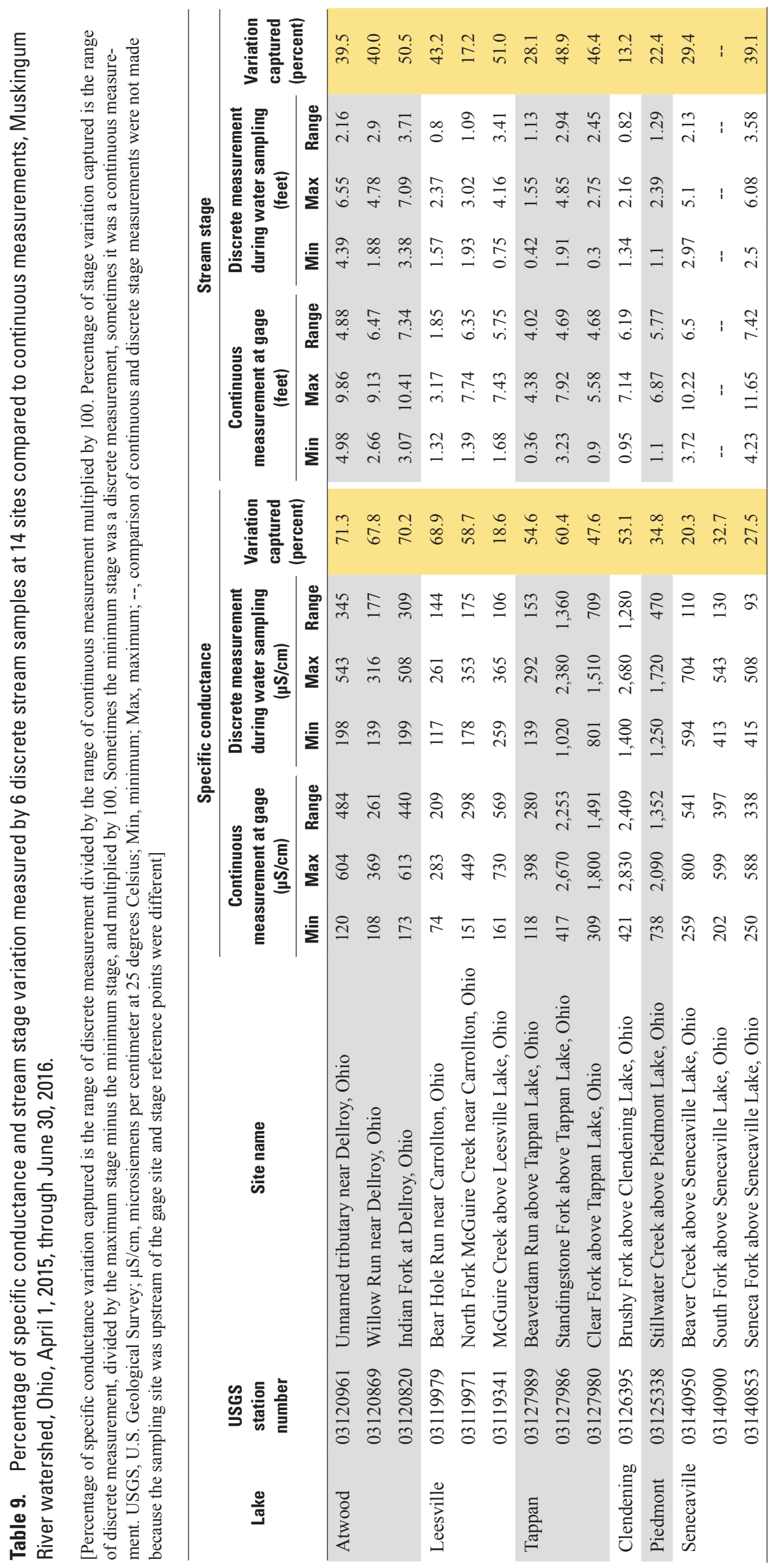


EXPLANATION

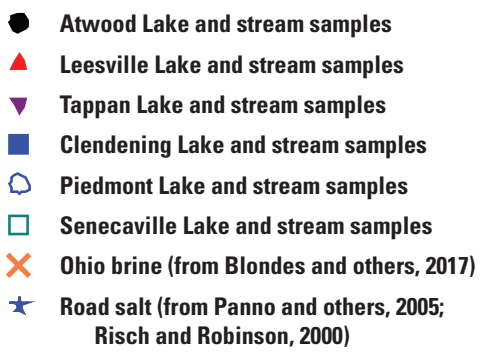

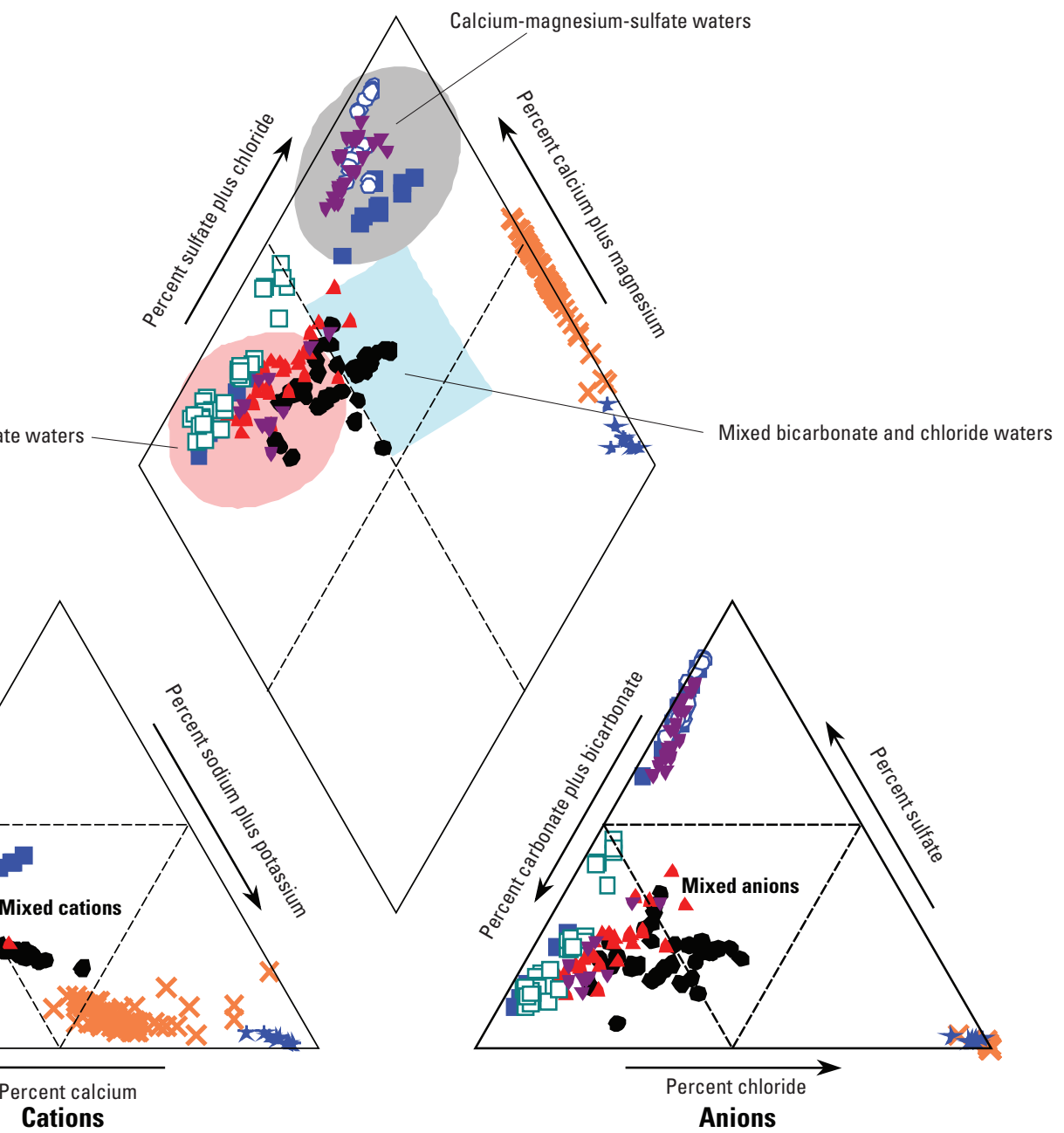

Figure 8. Major cation and anion percentages for 30 water-quality samples collected in Muskingum River watershed, Ohio, 2015-16.

Tappan Lake, Ohio; Clear Fork above Tappan Lake, Ohio; Tappan Lake at Main Swimmers Beach, Ohio; and Little Stillwater Creek below Tappan Dam at Tappan, Ohio), and most Clendening Lake sites (Brushy Fork above Clendening, Ohio, and Brushy Fork near Tippecanoe, Ohio) were sulfate-type waters. The highest specific conductance (higher than $410 \mu \mathrm{S} /$ $\mathrm{cm}$ ), elevated concentrations of total dissolved solids (higher than $285 \mathrm{mg} / \mathrm{L}$ ), sulfate (higher than $100 \mathrm{mg} / \mathrm{L}$ ), and magnesium (higher than $18 \mathrm{mg} / \mathrm{L}$ ) relative to other samples were observed in the sulfate-type waters.

The Ohio brines and road salt affected waters from Indiana and Illinois are sodium-chloride-type waters. Ion compositions enriched in chloride and sodium plus potassium relative to the other surface-water samples were observed in several samples from Atwood Lake drainage basin (depicted as black circles in fig. 8), indicating a chemistry intermediate between that of calcium-bicarbonate waters and Ohio brines or road salt - best seen on the small equilateral triangles of figure 8. Atwood Lake samples falling into the "mixed cation and anion" areas include Indian Fork at Dellroy, Ohio; Atwood
Lake at Main Swimmers Beach, Ohio; and Indian Fork below Atwood Dam near New Cumberland, Ohio. The highest chloride concentration $(76.1 \mathrm{mg} / \mathrm{L})$ among all sites was measured in a sample collected at Indian Fork at Dellroy, Ohio (upstream from Atwood Lake).

A relation between elevated sulfate concentrations and coal-mine drainage was determined in past studies (Helsel, 1983; Haefner and Simonson, 2010). Surface and underground coal mines are prevalent in the region (fig. 6). All 11 sites with sulfate-type water can be designated as "mine impacted" based on criteria (table 10) used during a recent assessment of mine drainage impacts (ODNR-DMRM, 2016). If any constituent concentration for a site met one of the ODNR-DMRM criteria for mild, moderate, or severe mine drainage, then the site was classified as "mine impacted." Sulfate and specific conductance values for 11 of the 30 sites fell into the mild to severe mine drainage impact categories of the ODNR-DMRM criteria. For the purposes of this study, describing severity of impact was not an objective, and sites meeting any level of criteria were classified as mine-impacted sites (table 11). 
Table 10. Chemical water-quality criteria for mine drainage impacts.

[>, greater than; <, less than; mg/L, milligrams per liter; cm, centimeter]

\begin{tabular}{|c|c|c|c|c|}
\hline Parameter & $\begin{array}{l}\text { No detectable mine } \\
\text { drainage impact }\end{array}$ & $\begin{array}{c}\text { Mild mine } \\
\text { drainage impact }\end{array}$ & $\begin{array}{l}\text { Moderate mine } \\
\text { drainage impact }\end{array}$ & $\begin{array}{c}\text { Severe mine } \\
\text { drainage impact }\end{array}$ \\
\hline $\mathrm{pH}$, standard units & $>6.0$ & 5.5 to 6.0 & 4.5 to 5.4 & $<4.5$ \\
\hline Total manganese, $\mathrm{mg} / \mathrm{L}$ & 0.0 to 0.5 & 0.5 to 2.0 & 2.1 to 4.0 & $>4.0$ \\
\hline Total aluminum, mg/L & 0.0 to 0.5 & 0.5 to 1.0 & 1.0 to 5.0 & $>5.0$ \\
\hline Alkalinity, mg/L & $>20.0$ & $<20.0$ & 0 & 0 \\
\hline Acidity & 0.0 to 20.0 & $>20.0$ & $\left({ }^{1}\right)$ & $\left({ }^{1}\right)$ \\
\hline
\end{tabular}

${ }^{1}$ Net alkaline water is goal at all times. Any net acid water is severe impact.

Table 11. List of mine-impacted sites per lake drainage basin for baseline water-quality study in Muskingum River watershed, Ohio, 2015-16.

[Sites are listed in order north to south. USGS, U.S. Geological Survey]

\begin{tabular}{lll}
\hline Lake drainage basin & \multicolumn{1}{c}{ Site name } & \multicolumn{1}{c}{ USGS station number } \\
\hline Tappan & Standingstone Fork above Tappan Lake, Ohio. & 03127986 \\
& Clear Fork above Tappan Lake, Ohio. & 03127980 \\
& Tappan Lake at Main Swimmers Beach, Ohio. & 401926081105100 \\
& Little Stillwater Creek below Tappan Dam at Tappan, Ohio. & 03128500 \\
\hline Clendening & Brushy Fork above Clendening Lake, Ohio. & 03126395 \\
& Brushy Fork near Tippecanoe, Ohio. & 03126910 \\
\hline Piedmont & Robinson Run above Piedmont Lake, Ohio. & 400606081085700 \\
& Stillwater Creek above Piedmont Lake, Ohio. & 03125338 \\
& Piedmont Lake near Piedmont, Ohio. & 400925081105700 \\
& Stillwater Creek below Piedmont Dam near Piedmont, Ohio. & 401139081125400 \\
\hline Senecaville & Beaver Creek above Senecaville Lake, Ohio. & 03140950 \\
\hline
\end{tabular}

The 11 mine-impacted sites included the sites with sulfatetype waters in figure 8 plus Beaver Creek above Senecaville Lake, Ohio, which plotted midway between bicarbonate-type and sulfate-type waters. The water quality at sites that are described in this report as being "non-mine-impacted" sites may not be totally unaffected by the mines, but those effects (if any) are lower than the criteria established by ODNRDMRM for mine-impacted sites.

Sulfate-to-chloride ratio plots have been used to differentiate oil and gas produced waters from natural waters and coal-related wastewaters (Wilson and others, 2014). Generally, higher median sulfate-to-chloride ratios are observed in coal-mine discharges and abandoned mine drainage than in inland surface water (Wilson and others, 2014). Conversely, the sulfate-to-chloride ratios observed in oil and gas produced waters are less than in inland surface water (Wilson and others, 2014). In this study, the median sulfate-to-chloride ratio ranged from 15 to 159 (fig. 9) in the samples collected from the 11 sites categorized as mine-impacted sites in table 11 . This is higher than the range associated with natural waters and within the range characteristic of coal-mine discharge and abandoned mine drainage (Wilson and others, 2014). In addition, the median sulfate-to-chloride ratios observed in samples collected from the 11 mine-impacted sites were distinctly higher than in samples collected from the study sites categorized as non-mine-impacted sites (fig. 9). Again, the water quality at the 19 sites that are described in this report as being "non-mine-impacted" may not be totally unaffected by the mines, but those effects (if any) appear to be lower than the 11 mine-impacted sites. 


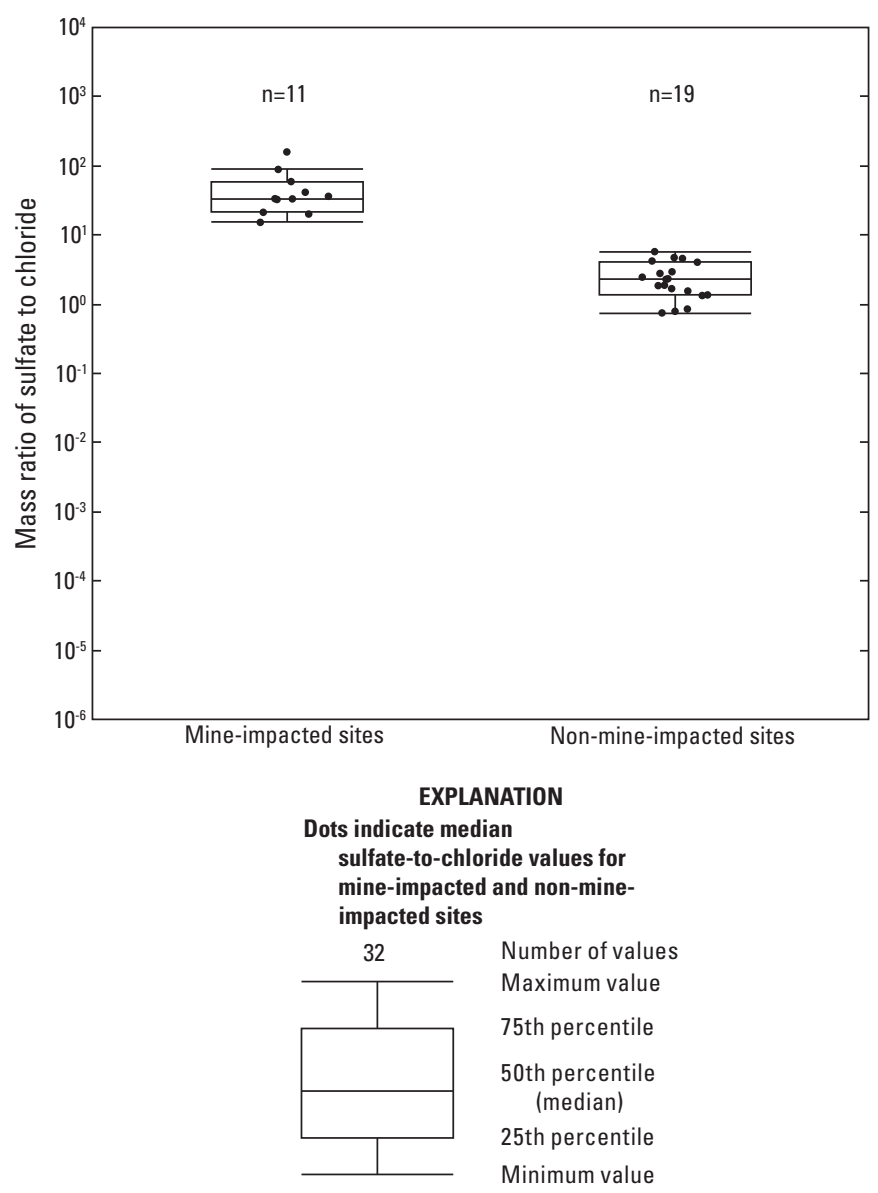

Figure 9. Median sulfate-to-chloride ratios for mine-impacted and non-mine-impacted sites in the Muskingum River watershed, Ohio, 2015-16.

\section{Sources of Salinity}

Potential sources of salinity in stream water include the runoff of road salt, brine spreading for dust control, septic system leachate, and wastewater treatment plant effluent-all of which occur in the study area. An accidental release of oil- and gas-related brines could increase salinity (sodium and chloride), the concentration of total dissolved solids in shallow groundwater and streams, and specific conductance.

A technique to discern sources of chloride in water is the comparison of weight ratios of chloride and bromide concentrations in a sample (Whittemore, 1988; Knuth and others, 1990; Davis and others, 1998). Chloride and bromide are useful indicators of sources of salinity because they are (1) highly soluble; (2) minimally affected by adsorption to sediment once dissolved in water; (3) not altered by oxidation-reduction reactions; and (4) not detected in high concentrations in common rock-forming minerals, except for evaporite minerals such as halite (sodium chloride) (Feth, 1981). Differences in chloride-to-bromide ( $\mathrm{Cl}: \mathrm{Br})$ ratios occur because bromide is more soluble in water than chloride (Davis and others, 1998). As seawater evaporates, sodium chloride in the residual water becomes saturated and precipitates (crystallizes) first, leaving a residual brine with a higher bromide concentration relative to chloride. If the sodium chloride (either as a natural rock salt deposit or applied as road salt) is subsequently dissolved in freshwater, the water will become more enriched in chloride relative to bromide and will thus exhibit a higher $\mathrm{Cl}: \mathrm{Br}$ ratio. Residual brines, which can be present in deep aquifers as fossil water that was trapped at the time of sediment deposition, will be enriched with bromide relative to chloride and will exhibit a much lower $\mathrm{Cl}: \mathrm{Br}$ ratio (Davis and others, 1998). Such residual brines often are brought to land surface as a byproduct of oil and gas production (OEPA, 2014).

Following methods described in Whittemore (1988), simple binary mixing curves (figs. $10 A-10 D$ ) were prepared to show how the $\mathrm{Cl}: \mathrm{Br}$ ratio of dilute stream water would change with the addition of increasing amounts of two concentrated solutions - saturated halite (road salt) solution and oil-field brine. The halite and brine solutions and the dilute, unaffected stream water are referred to as "end-members" because they represent the starting and stopping points of the possible mixing process.

The sample from Coleman Run above Clendening Lake, Ohio, collected on May 12, 2016, was the lowest chloride concentration of any sample collected for this study $(2.12 \mathrm{mg} / \mathrm{L})$ (USGS, 2017a) and was used as the dilute-water end-member; this sample is represented by the location at which all lines diverge on the left side of the graph (figs. $10 A-10 D$ ). The $\mathrm{Cl}: \mathrm{Br}$ ratios of the brine end-members were determined using chemical data from multiple samples of Ohio brines produced from the Berea and Clinton Sandstones (Blondes and others, 2017), which are the primary target formations for the conventional wells drilled in the study area (ODNR, Division of Oil \& Gas Resources, 2017a). No chemical analyses of brine samples from the Utica Shale were available in the produced water database (Blondes and others, 2017) to use as an endpoint. Mixing curves were calculated using the brine samples from each formation having the highest and lowest $\mathrm{Cl}: \mathrm{Br}$ ratios as the brine endpoints. Two road salt endpoints were used to show a range of possible concentrations. The uppermost $\mathrm{Cl}: \mathrm{Br}$ value for the road salt endpoint (depicted as a green square in figs. $10 A-10 D$ ) is road salt runoff collected beneath a bridge in Western Springs, Ill. (Panno and others, 2005). The lesser road salt endpoint (depicted as a yellow square in figs. $10 A-10 D$ ) was computed as the mean of three samples of road salt applied in northeastern Ohio (collected by Knuth and others, 1990). The green square shown between these two values represents a concentrated saline solution made by Panno and others (2005) from road salt collected at an Illinois Department of Transportation salt-storage facility. Panno and others (2005) determined that septic system effluent also could plot near the road salt endpoints if collected during or immediately following regeneration of a household water-softener ion exchange column. Other septic effluent, wastewater treatment plant effluent, animal wastes, and water from field tiles (agricultural subsurface drainage systems) can plot between the brine and road salt mixing curves. 


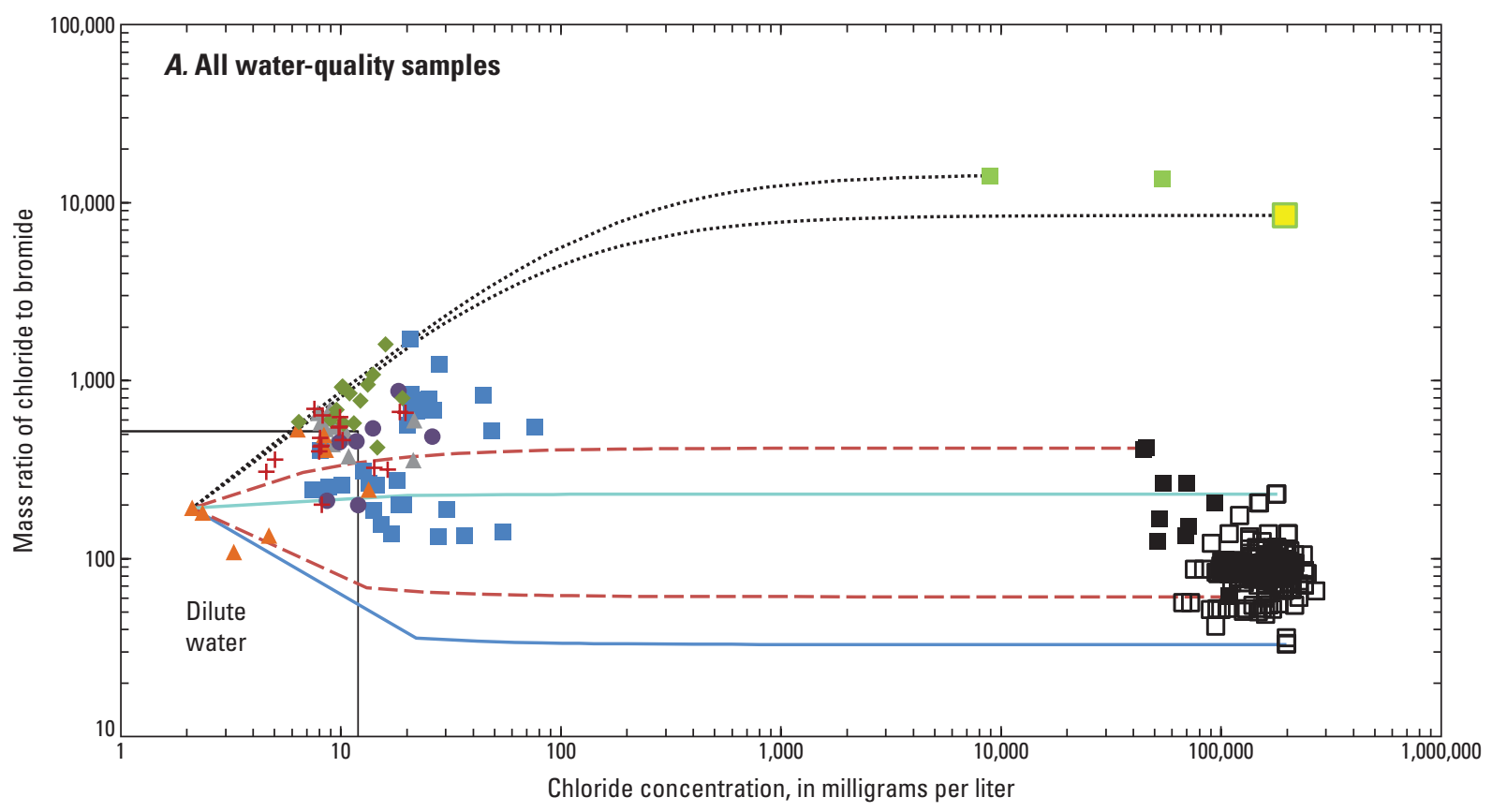

\section{EXPLANATION}

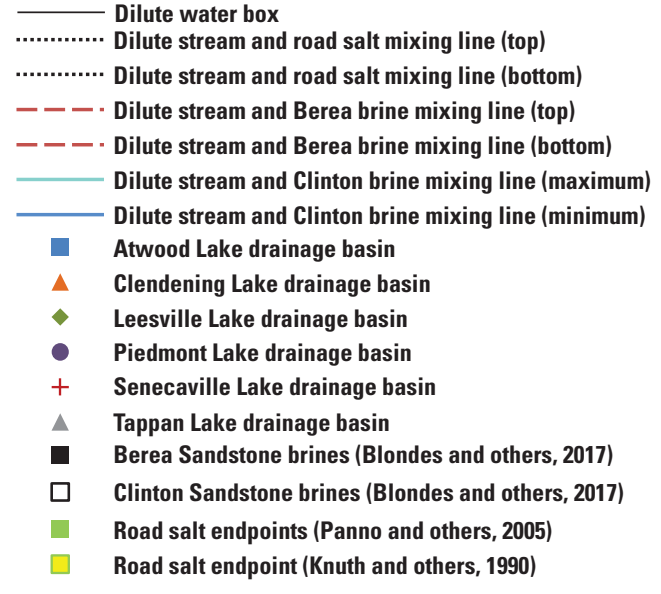

Figure 10. Binary mixing curves for chloride-to-bromide ratios in the Muskingum River watershed, 0hio, 2015-16. $A$, all water-quality samples; $B$, Atwood Lake samples; $C$, Leesville Lake samples; and $D$, Senecaville Lake samples. 


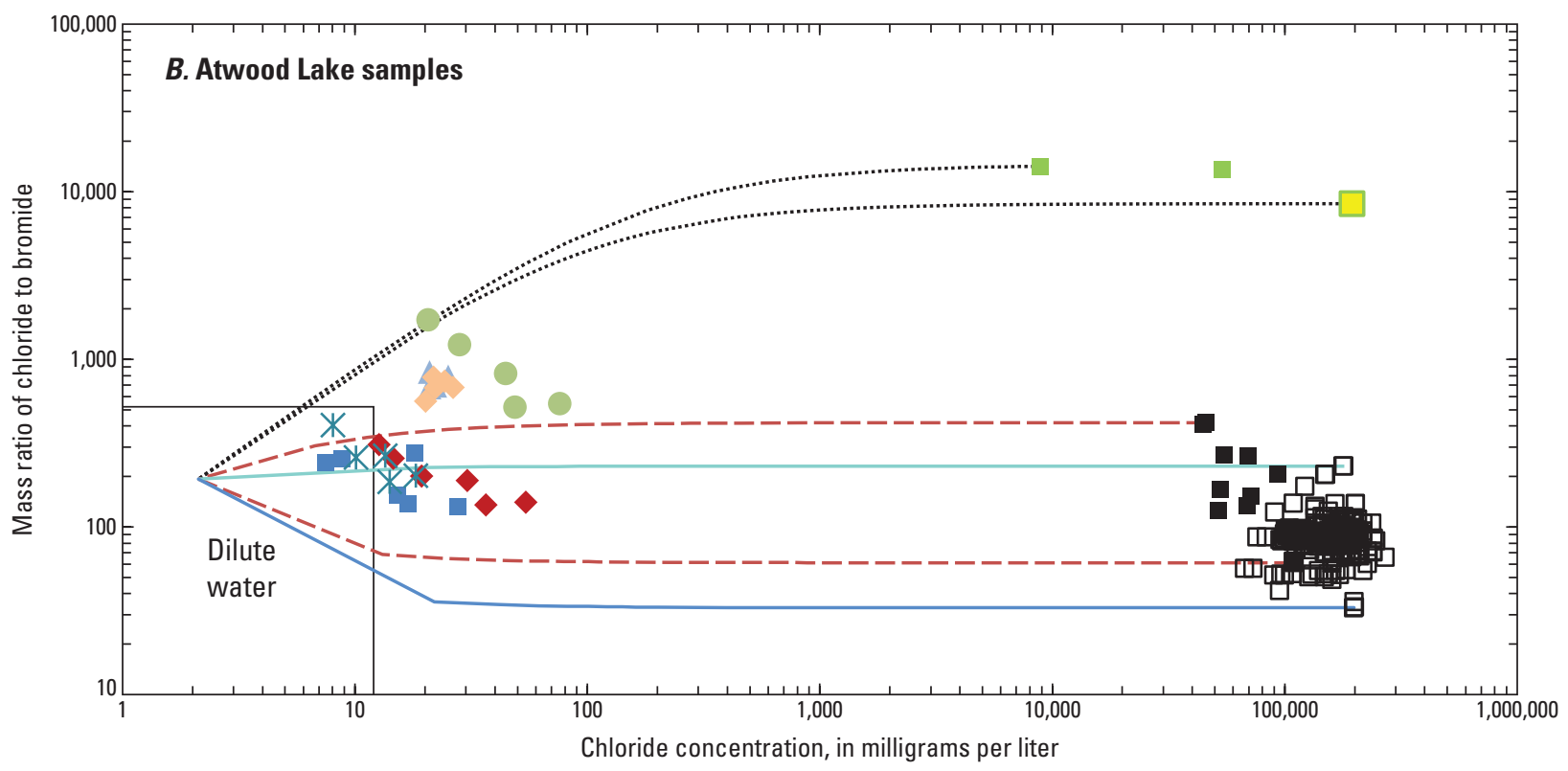

EXPLANATION

\begin{tabular}{|c|c|}
\hline ...... & $\begin{array}{l}\text { Dilute water box } \\
\text { Dilute stream and road salt mixing line (top) }\end{array}$ \\
\hline .............. & Dilute stream and road salt mixing line (bottom) \\
\hline$---\cdot$ & Dilute stream and Berea brine mixing line (top) \\
\hline--- & Dilute stream and Berea brine mixing line (bottom) \\
\hline & Dilute stream and Clinton brine mixing line (maximum) \\
\hline & Dilute stream and Clinton brine mixing line (minimum) \\
\hline $\mathbf{\square}$ & Elliot Run near Dellroy, Ohio \\
\hline$\bullet$ & Unnamed tributary near Dellroy, Ohio \\
\hline * & Willow Run near Dellroy, Ohio \\
\hline ○ & Indian Fork at Dellroy, Ohio \\
\hline$\Delta$ & Atwood Lake at Main Swimmers Beach, Ohio \\
\hline$\diamond$ & Indian Fork below Atwood Dam near New Cumberland, Ohio \\
\hline $\mathbf{\square}$ & Berea Sandstone brines (Blondes and others, 2017) \\
\hline$\square$ & Clinton Sandstone brines (Blondes and others, 2017) \\
\hline$\square$ & Road salt endpoints (Panno and others, 2005) \\
\hline$\square$ & Road salt endpoint (Knuth and others, 1990) \\
\hline
\end{tabular}

Figure 10. Binary mixing curves for chloride-to-bromide ratios in the Muskingum River watershed, Ohio, 2015-16. A, all water-quality samples; $B$, Atwood Lake samples; $C$, Leesville Lake samples; and $D$, Senecaville Lake samples. - Continued 


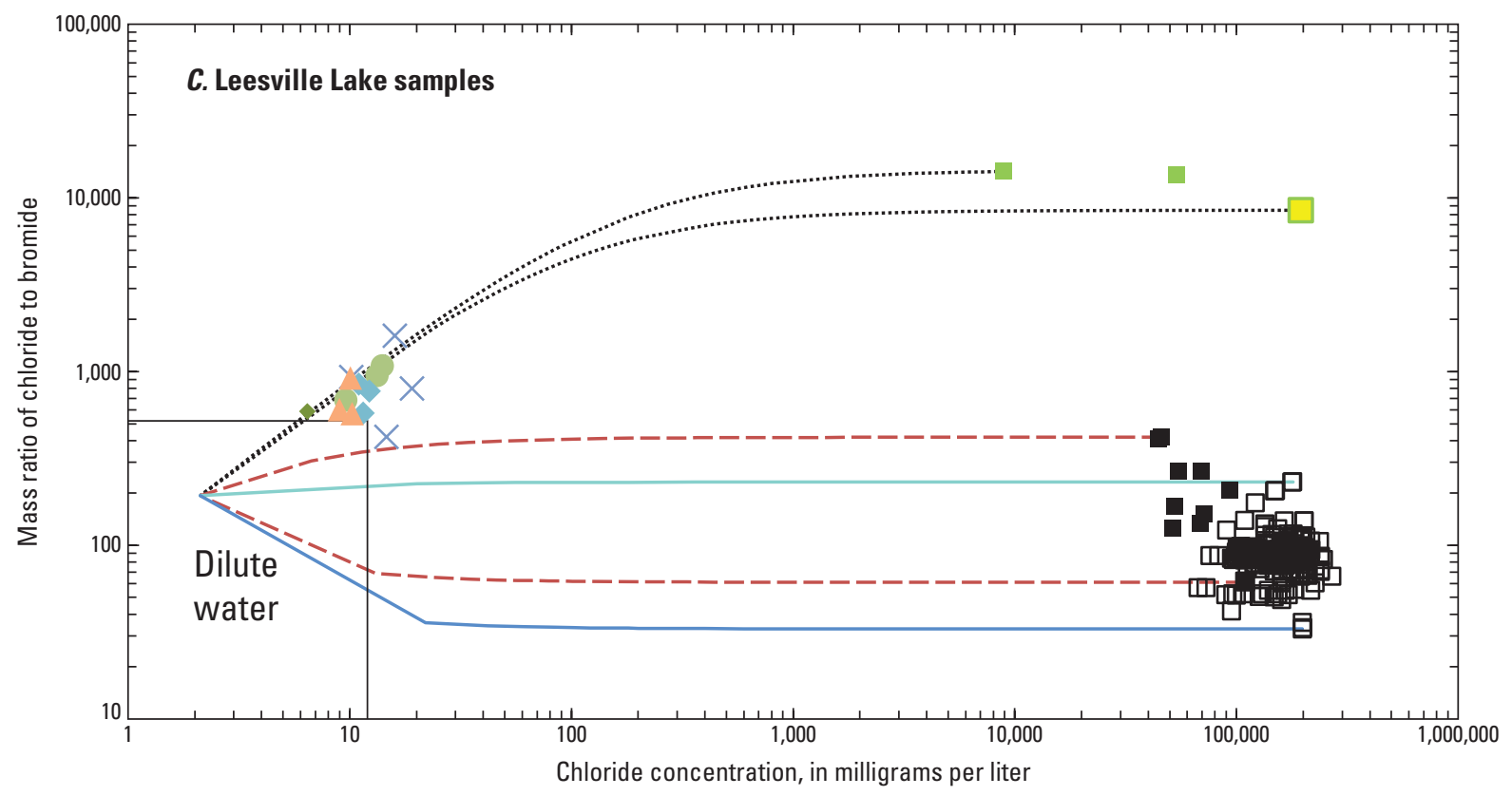

\section{EXPLANATION}

\begin{tabular}{|c|c|}
\hline$\cdots \cdot$ & $\begin{array}{l}\text { Dilute water box } \\
\text { Dilute stream and road salt mixing line (top) }\end{array}$ \\
\hline & Dilute stream and road salt mixing line (bottom) \\
\hline - - - & Dilute stream and Berea brine mixing line (top) \\
\hline--- & Dilute stream and Berea brine mixing line (bottom) \\
\hline & Dilute stream and Clinton brine mixing line (maximum) \\
\hline & Dilute stream and Clinton brine mixing line (minimum) \\
\hline$\bullet$ & Bear Hole Run near Carrollton, Ohio \\
\hline$x$ & Unnamed tributary to McGuire Creek near Carrollton, Ohio \\
\hline - & McGuire Creek near Leesville, Ohio (gage) \\
\hline$\diamond$ & McGuire Creek above Leesville Lake, Ohio \\
\hline$\Delta$ & McGuire Creek near Leesville, Ohio (gage) \\
\hline $\mathbf{\square}$ & Berea Sandstone brines (Blondes and others, 2017) \\
\hline$\square$ & Clinton Sandstone brines (Blondes and others, 2017) \\
\hline$\square$ & Road salt endpoints (Panno and others, 2005) \\
\hline$\square$ & Road salt endpoint (Knuth and others, 1990) \\
\hline
\end{tabular}

Figure 10. Binary mixing curves for chloride-to-bromide ratios in the Muskingum River watershed, 0hio, 2015-16. $A$, all water-quality samples; $B$, Atwood Lake samples; $C$, Leesville Lake samples; and $D$, Senecaville Lake samples.-Continued 


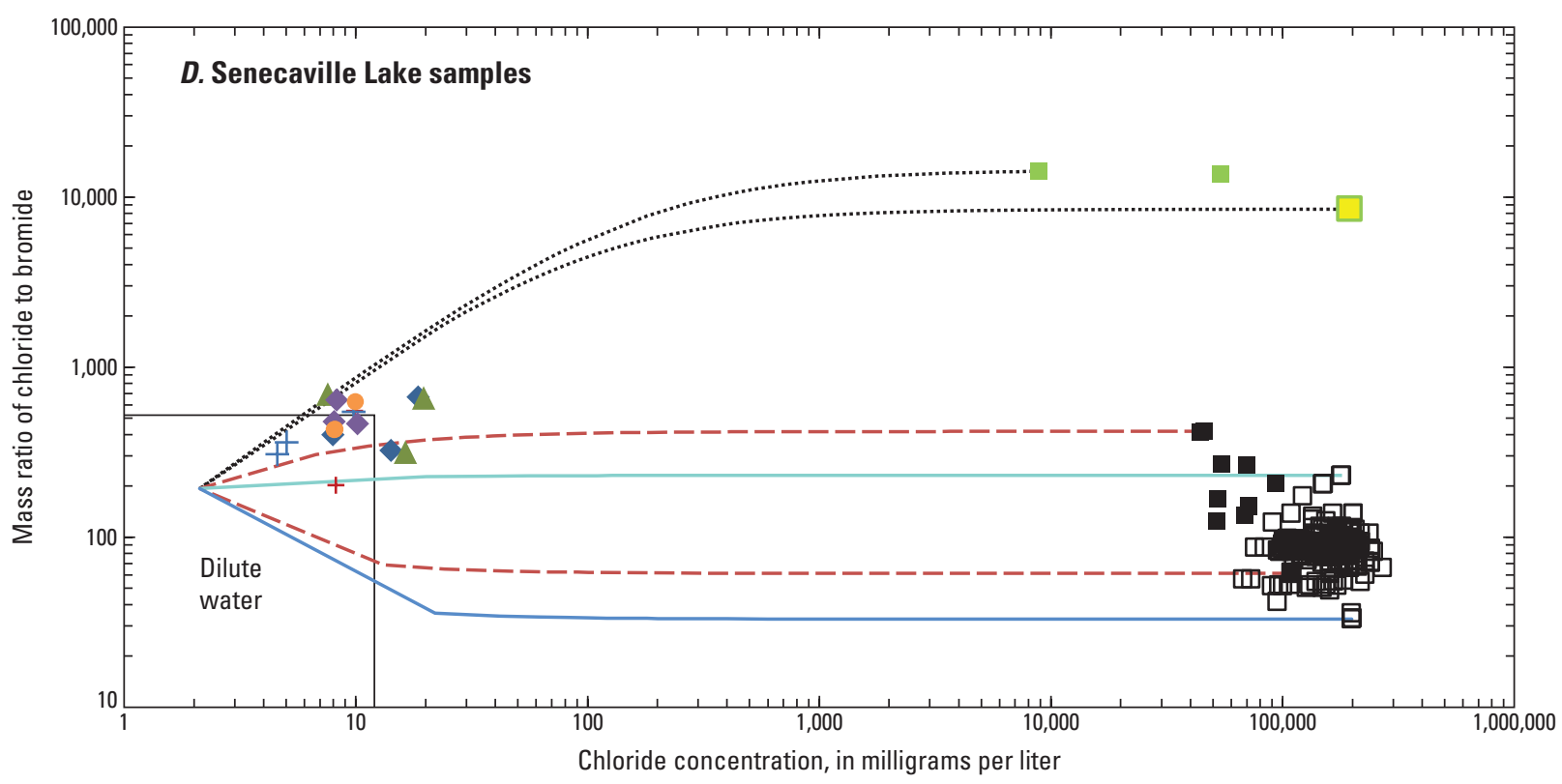

\section{EXPLANATION}

\begin{tabular}{|c|c|}
\hline & $\begin{array}{l}\text { Dilute water box } \\
\text { Dilute stream and road salt mixing line (top) }\end{array}$ \\
\hline & Dilute stream and road salt mixing line (bottom) \\
\hline--- & Dilute and Berea brine mixing line (top) \\
\hline--- & Dilute stream and Berea brine mixing line (bottom) \\
\hline & Dilute stream and Clinton brine mixing line (maximum) \\
\hline & Dilute stream and Clinton brine mixing line (minimum) \\
\hline+ & Glady Run above Senecaville Lake, Ohio \\
\hline$\diamond$ & Beaver Creek above Senecaville Lake, Ohio \\
\hline $\boldsymbol{\Delta}$ & South Fork at TR199 above Senecaville Lake, Ohio \\
\hline+ & Seneca Fork above Senecaville Lake, Ohio \\
\hline$\bullet$ & Seneca Lake at Swimming Beach near Senecaville, Ohio \\
\hline$\bullet$ & Seneca Fork below Senecaville Dam near Senecaville, Ohio \\
\hline $\mathbf{0}$ & Berea Sandstone brines (Blondes and others, 2017) \\
\hline$\square$ & Clinton Sandstone brines (Blondes and others, 2017) \\
\hline$\square$ & Road salt endpoints (Panno and others, 2005) \\
\hline$\square$ & Road salt endpoint (Knuth and others, 1990) \\
\hline
\end{tabular}

Figure 10. Binary mixing curves for chloride-to-bromide ratios in the Muskingum River watershed, Ohio, 2015-16. $A$, all water-quality samples; $B$, Atwood Lake samples; $C$, Leesville Lake samples; and $D$, Senecaville Lake samples.—Continued 
The area designated as dilute water in figures $10 A-10 D$ is based on the maximum chloride concentration $(12 \mathrm{mg} / \mathrm{L})$ and the maximum $\mathrm{Cl}: \mathrm{Br}$ ratio (521) reported by Panno and others (2005) for samples of Midwestern precipitation, soil water, and groundwater deemed to be unaffected by sodium chloride contamination. These results are similar to results of Jones and Sroka (1997), who estimated that shallow wells in Ohio that were unaffected by sodium chloride dissolution had chloride concentrations less than $10 \mathrm{mg} / \mathrm{L}$.

Water samples collected as part of this baseline study in which bromide concentrations higher than the laboratory reporting level were observed are plotted on figures $10 A-10 D$. Samples that plotted outside of the dilute water region and within the bounds of the upper and lower mixing curves between dilute water and brines from the Clinton Formation (depicted by blue lines) and Berea Sandstone (depicted by red dashed lines) consist primarily of samples from the Atwood Lake drainage basin (fig. 10A) — specifically, multiple samples from Unnamed tributary near Dellroy, Ohio; Elliot Run near Dellroy, Ohio; and Willow Run near Dellroy, Ohio (fig. 10B). Drainage areas upstream from these three sites are about 3.4 to 7.8 square miles - small (in the bottom quartile) compared with other sampling site drainages in the study area (table 3 ). Dividing the number of conventional oil and gas wells upstream from these sites (table 12) by the upstream drainage area (table 3) revealed that three of the four highest densities of conventional oil and gas wells (6.9 to 9.2 wells per square mile) occurred in Unnamed tributary near Dellroy, Ohio; Elliot Run near Dellroy, Ohio; and Willow Run near Dellroy, Ohio. Only the drainage basin of Willow Run near Dellroy, Ohio, contains a Utica/Point Pleasant formation (shale-gas) well; drainage basins of the other two streams contain active or plugged injection wells, or both (table 12). For each of these three streams, the samples with the strongest brine signature as indicated by the highest chloride concentrations and lowest $\mathrm{Cl}$ :Br ratios (fig. 10B) were collected in August and October 2015, when streamflow was low and the proportion of base flow was likely higher than other times during the study period (figs. 1-1A and 1-1B). Samples from the same three sites having the weakest brine signature (lowest chloride concentrations and the highest $\mathrm{Cl}: \mathrm{Br}$ ratios) were collected during the high flow event on March 2016 (figs. 1-1A and 1-1B), when the proportion of runoff was high. Some of these weak brine signature samples plot in the dilute water region of the mixing curve. Based on binary mixing calculations, the maximum percentage of brine input denoted by these samples is 0.1 percent Berea brine, 99.9 percent dilute water (or an even lower percentage -0.03 percent brine - if the endpoint is a more saline brine from the Clinton Formation).

Single samples from four other sites plotted within the bounds of the Berea brine mixing curves-South Fork at TR119 above Senecaville Lake, Ohio, on August 18, 2015, and Beaver Creek above Senecaville Lake, Ohio, on August 25, 2015 (fig. 10D); Brushy Fork above Clendening Lake, Ohio, on October 27, 2015 (denoted by an orange triangle in fig. 10A); and Clear Fork above Tappan Lake,
Ohio, on October 22, 2015 (denoted by a grey triangle in fig. 10A). Drainage basin area of these streams range from 17 to 35.9 square miles (table 3 ). Densities of conventional oil and gas wells in upstream drainage basins of these streams range from 0.5 to 8.6 wells per square mile. Densities of Utica/ Point Pleasant formation (shale-gas) wells range from 0.4 to 1.6 wells per square mile (calculated from tables 3 and 12; not shown).

Several samples from Leesville Lake drainage basin (fig. 10C) plot on or near the mixing curves between dilute water and road salt endpoints. Some of the highest chloride concentrations for the Leesville Lake drainage basin occurred at Unnamed tributary to McGuire Creek near Carrollton, Ohio, with the sample from March 14, 2016, (high flow) plotting near the road salt mixing line and samples from August and October 2015 (low flow) plotting in the area between the road salt and brine curves. Panno and others (2005) determined that samples plotting in this intermediate area were from known sources such as septic waste, wastewater treatment plant effluent, water from field tiles, and water affected by animal waste. The same scenario (road salt mixing at high flow in March 2016, intermediate $\mathrm{Cl}: \mathrm{Br}$ ratios in August and October 2015) is observed in samples from Indian Fork at Dellroy, Ohio, in the Atwood Lake drainage basin (fig. 10B).

\section{Concentrations or Levels of Selected Constituents and Properties}

The following are key concepts to understanding the data presented in this section of the report: (1) types of waterquality and streamflow information conveyed in boxplots; (2) relation of concentration to streamflow and what that implies about the source of a constituent; (3) water-quality criteria; and (4) the different environments represented by samples from tributaries, lakes, and sites downstream from dams.

Types of water-quality and streamflow information conveyed in boxplots. - Medians and ranges of water-quality measurements at each sampling site were visually evaluated by use of boxplots (figs. 2-1 through 2-40) to compare constituent concentrations and levels of physical properties among lake drainage basins. Within each lake drainage basin, the boxplots facilitate (1) comparison of measurements at reference sites (those with no upstream shale-gas development) to those at other sites in the subbasin and (2) assessment of water-quality variation with streamflow and from upstream to downstream from the lakes. Most of the VOC results could not be evaluated by use of boxplots, because concentrations were less than laboratory reporting levels.

The sampling sites for an individual lake drainage basin are arranged left-to-right in the boxplots in the order of increasing drainage basin area, which in most cases results in boxplots being ordered from upstream to downstream. A diagonal-lined background notes the reference site for each lake. Single samples are represented by a solid circle. The symbols 


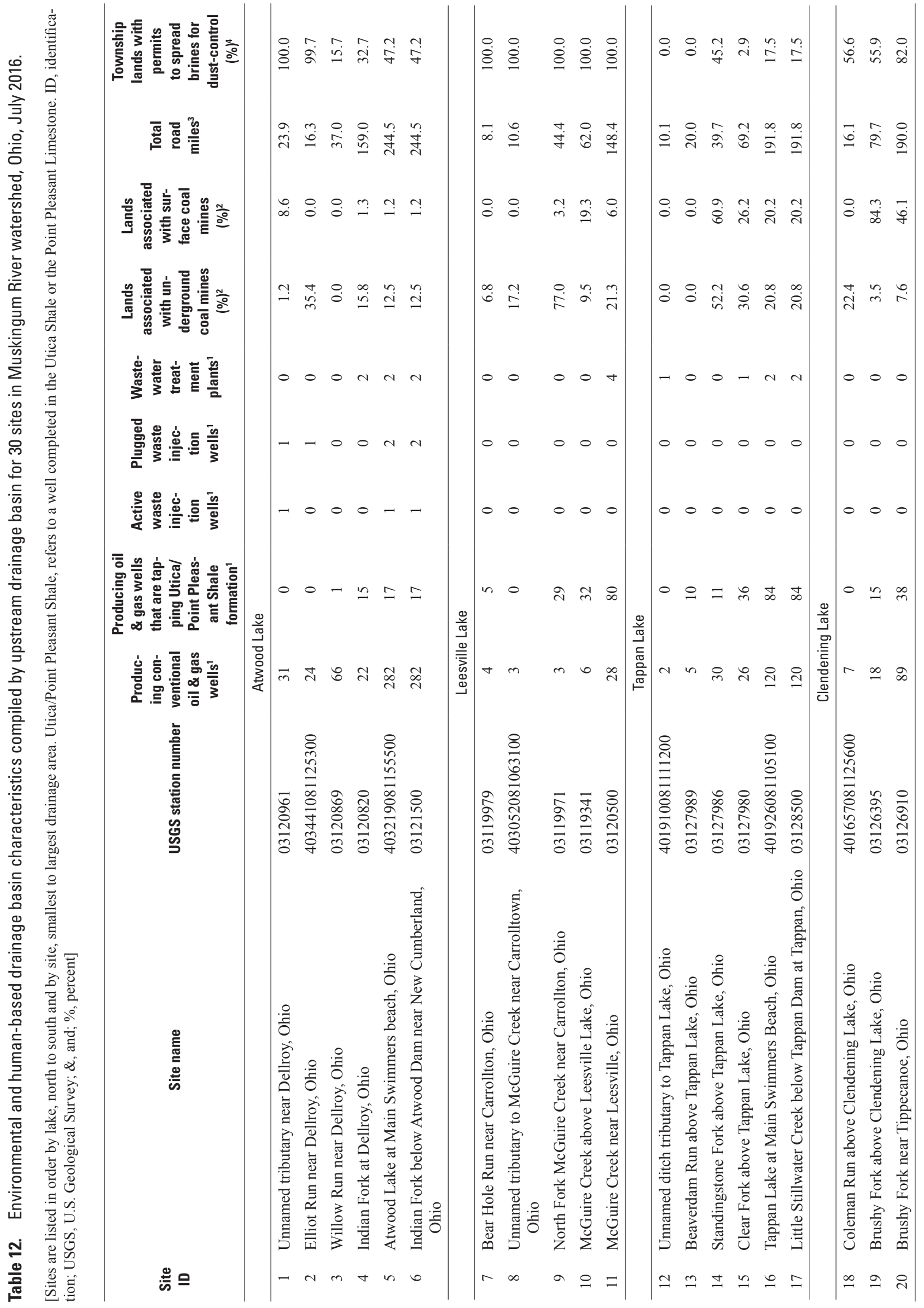




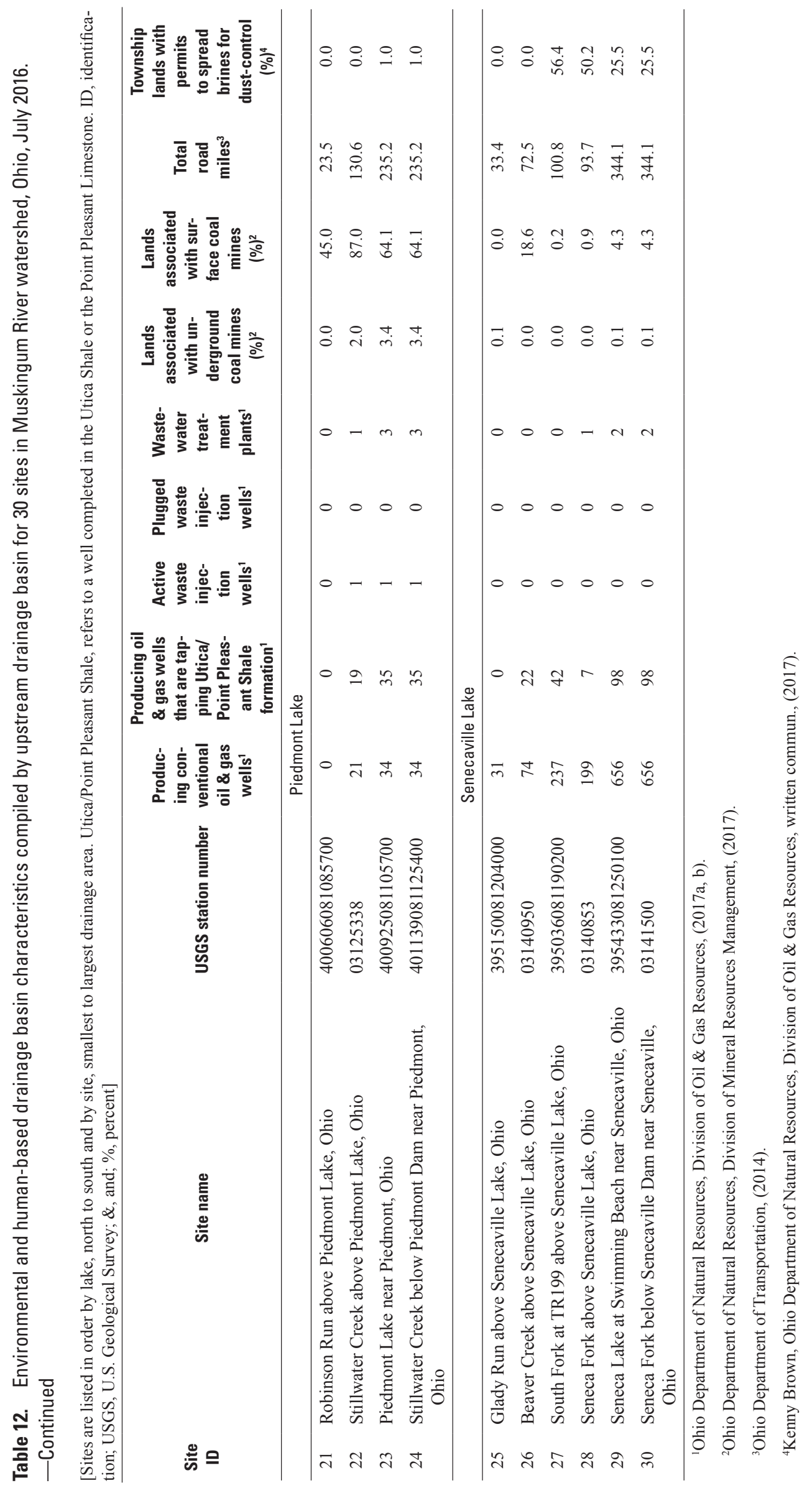


are blue if the sample was collected when the streamflow at the time of sample collection was higher than the median instantaneous streamflow for that site, and the symbols are black when the streamflow was less than the median instantaneous streamflow. White circles represent a lack of streamflow data; for example, lake sites or missing streamflow measurements. Sites represented on the right-hand edge of each plot are sites below the dam. Site names in red text are sites classified as being coal-mine-impacted sites.

Relation of measured water-quality values to streamflow and what that implies about the source of a constituent.Evaluation of the boxplots (figs. 2-1 through 2-40) indicates that higher-than-median concentrations or levels of several constituents and properties generally occurred in samples collected during less-than-median streamflows (denoted by black dots on boxplots) at most of the sites, as listed in table 13. Because base flow contributes a higher proportion of streamflow at low flow than at high flow, this pattern suggests that measured values of these constituents and properties are generally higher in groundwater than in runoff (although the same pattern - higher constituent values at lower flows at multiple sites - could be seen if steadily discharging point sources in multiple drainage basins were diluted by runoff during rainfall). Constituents and properties that were generally observed at higher values in samples collected during higherthan-median streamflows (denoted by blue dots on boxplots) include those typically associated with runoff-turbidity, aluminum, zinc, nitrate plus nitrite, and suspended sediment (table 13).

Water-quality criteria.-The OEPA developed waterquality numerical/narrative criteria to protect the use and value of water resources in Ohio. Every water body in Ohio is assigned a beneficial use designation for the protection of aquatic life, based on a set of biological criteria. The beneficial use designation assigned to a stream dictates the specific chemical criteria applied to that stream (hereafter referred to as "aquatic life use criteria"). Measured $\mathrm{pH}$ and constituent concentrations at the 30 sampling sites were compared to aquatic life use criteria to assess the potential for adversely affecting stream biota (table 14). Standards do not exist for all constituents targeted for analysis.

The sampling sites for this investigation all have the same beneficial use designation - warmwater habitat - except for two sites: Stillwater Creek above Piedmont Lake, Ohio, and Stillwater Creek below Piedmont Dam near Piedmont, Ohio (Ohio Administrative code 3745-1-24 [LAWriter Ohio Laws and Rules, 2017a]). The Stillwater Creek headwaters to Brushy Fork segment currently (2015-16) is listed as a limited warmwater habitat because of mine drainage. Based on 2012 field assessments, however, the OEPA is recommending that all Stillwater Creek drainage basin streams be redesignated as warmwater habitat (OEPA, 2017a).

Water samples for this investigation were not collected near known wastewater discharge mixing zones and are, therefore, considered to be subject to the OEPA "outside mixing zone maximum" (OMZM) and "outside mixing zone average"
Table 13. Constituents and properties indicating a relation between measured value and streamflow at most sites in the study area, Muskingum River watershed, Ohio, 2015-16.

\begin{tabular}{|c|c|}
\hline Constituent & $\begin{array}{l}\text { Percent of sample concentrations greater } \\
\text { than median' that occurred at low flow }\end{array}$ \\
\hline \multicolumn{2}{|c|}{$\begin{array}{l}\text { Greater concentrations generally occurred at } \\
\text { less-than-median flows (low flow) }\end{array}$} \\
\hline Specific conductance & 91 \\
\hline Alkalinity & 86 \\
\hline Calcium & 83 \\
\hline Magnesium & 86 \\
\hline Sodium & 75 \\
\hline Chloride & 73 \\
\hline Bicarbonate & 84 \\
\hline Carbonate & 79 \\
\hline Fluoride & 88 \\
\hline Arsenic & 88 \\
\hline Barium & 85 \\
\hline Bromide & 93 \\
\hline Iron & 60 \\
\hline Manganese & 64 \\
\hline Strontium & 87 \\
\hline Total dissolved solids & 85 \\
\hline Ammonia & 71 \\
\hline Orthophosphate & 79 \\
\hline Organic carbon & 80 \\
\hline Styrene & 100 \\
\hline \multicolumn{2}{|c|}{$\begin{array}{l}\text { Greater concentrations generally occurred at } \\
\text { greater-than-median flows (high flows) }\end{array}$} \\
\hline Dissolved oxygen & 274 \\
\hline Turbidity & 62 \\
\hline Aluminum & 88 \\
\hline Zinc & 71 \\
\hline Nitrate plus nitrite & 72 \\
\hline Suspended sediment & 65 \\
\hline
\end{tabular}

${ }^{1}$ For these calculations, median concentration and median flow at each individual site were determined. The number of samples having greaterthan-median concentrations of a constituent under the specified flow conditions (either greater-than- or less-than-median) at an individual site were summed for all sites and divided by the total number of samples in the entire dataset that were collected at (A) less-than-median flow (low flow) or (B) greater-than-median flow (high flow). Sample concentrations that tied with the median concentration for the site were not included in this calculation. Ties with the median included a few detected concentrations, but most occurred when the median concentration was below the reporting level.

${ }^{2}$ It is difficult to separate the effects of streamflow from those of temperature on dissolved oxygen concentrations. Cold water can hold more dissolved oxygen than warm water (U.S. Geological Survey, 2017c). In the study area, dissolved oxygen concentrations are negatively correlated to water temperature at stream, lake, and gage (below-dam) sites at statistically significant levels (Spearman's rank correlation coefficients of -0.63 , -0.70 , and -0.92 , respectively). The coldest water temperatures were generally measured in March, which coincided with higher streamflows; warmest temperatures were generally measured in June and August, when streamflows were relatively low. 
Table 14. Ohio Environmental Protection Agency aquatic life use criteria and exceedances for baseline water-quality study in Muskingum River watershed, Ohio, 2015-16.

[Exceedance, criteria was not met; OMZM, outside mixing zone minimum; OMZA, outside mixing zone average; \%, percent; <, less than; WWH, warmwater habitat site designation; LWR, limited warmwater habitat site designation; N/A, not applicable; ${ }^{\circ} \mathrm{C}$, degrees Celsius; $\mathrm{mg} / \mathrm{L}$, milligrams per liter; $\mu \mathrm{g} / \mathrm{L}$, micrograms per liter; e, the base e exponential function; ln $\mathrm{H}$, the natural logarithm of the water hardness; $\mathrm{N}$, nitrogen; $\mathrm{pCi} / \mathrm{L}$, picocurie per liter]

\begin{tabular}{|c|c|c|c|c|c|c|}
\hline \multirow[b]{2}{*}{ Property or constituent } & \multirow[b]{2}{*}{ Units } & \multicolumn{2}{|c|}{ Aquatic life use criteria } & \multirow[b]{2}{*}{ Site name } & \multirow{2}{*}{$\begin{array}{c}\text { Sampling } \\
\text { date }^{2}\end{array}$} & \multirow{2}{*}{$\begin{array}{l}\text { Exceed- } \\
\text { ance } \\
\text { result }\end{array}$} \\
\hline & & OMZM (or similar) & $\begin{array}{c}\text { OMZA' }^{1} \\
\text { (or similar) }\end{array}$ & & & \\
\hline Dissolved oxygen & $\begin{array}{l}\% \text { of satu- } \\
\text { ration }\end{array}$ & $<4$ for WWH $(<2.0$ for LWR) & $\left({ }^{3}\right)$ & $\begin{array}{l}\text { Brushy Fork near } \\
\text { Tippecanoe, Ohio }\end{array}$ & $8 / 12 / 2015$ & 2.6 \\
\hline $\mathrm{pH}$ & N/A & N/A & $<6.5$ & Not exceeded & $\mathrm{N} / \mathrm{A}$ & N/A \\
\hline Total dissolved solids & $\mathrm{mg} / \mathrm{L}$ & $\mathrm{N} / \mathrm{A}$ & 1,500 & $\begin{array}{l}\text { Standingstone Fork above } \\
\text { Tappan Lake, Ohio }\end{array}$ & $\mathrm{N} / \mathrm{A}$ & $1,527.50$ \\
\hline Total dissolved solids & $\mathrm{mg} / \mathrm{L}$ & N/A & 1,500 & $\begin{array}{l}\text { Brushy Fork above } \\
\text { Clendening Lake, Ohio }\end{array}$ & $\mathrm{N} / \mathrm{A}$ & 1,738 \\
\hline Arsenic & $\mu \mathrm{g} / \mathrm{L}$ & 340 & 150 & Not exceeded & $\mathrm{N} / \mathrm{A}$ & $\mathrm{N} / \mathrm{A}$ \\
\hline Barium & $\mu \mathrm{g} / \mathrm{L}$ & 2,000 & 220 & Not exceeded & $\mathrm{N} / \mathrm{A}$ & N/A \\
\hline Boron & $\mu \mathrm{g} / \mathrm{L}$ & 33,000 & 3,900 & Not exceeded & $\mathrm{N} / \mathrm{A}$ & $\mathrm{N} / \mathrm{A}$ \\
\hline Strontium & $\mu \mathrm{g} / \mathrm{L}$ & 40,000 & 21,000 & Not exceeded & N/A & N/A \\
\hline Zinc & $\mu \mathrm{g} / \mathrm{L}$ & $\begin{array}{l}\text { Varies }^{4} \text { by hardness using } \\
\text { equation: } \mathrm{e}(0.8473[\operatorname{ln~} \mathrm{H}] \\
\text { plus } 0.884)\end{array}$ & N/A & Not exceeded & $\mathrm{N} / \mathrm{A}$ & N/A \\
\hline Ammonia & $\mathrm{mg} / \mathrm{L}$ as $\mathrm{N}$ & $\begin{array}{l}\text { Varies }^{5} \text { by water temperature } \\
\text { and } \mathrm{pH}\end{array}$ & $\left({ }^{3}\right)$ & Not exceeded & $\mathrm{N} / \mathrm{A}$ & $\mathrm{N} / \mathrm{A}$ \\
\hline 1,2-Dichloroethane & $\mu \mathrm{g} / \mathrm{L}$ & 9,600 & 2,000 & Not exceeded & N/A & N/A \\
\hline 1,2,4-Trimethylbenzene & $\mu \mathrm{g} / \mathrm{L}$ & 140 & 15 & Not exceeded & N/A & N/A \\
\hline 1,3,5-Trimethylbenzene & $\mu \mathrm{g} / \mathrm{L}$ & 230 & 26 & Not exceeded & $\mathrm{N} / \mathrm{A}$ & $\mathrm{N} / \mathrm{A}$ \\
\hline 4-Isopropyltoluene & $\mu \mathrm{g} / \mathrm{L}$ & 150 & 16 & Not exceeded & N/A & N/A \\
\hline Benzene & $\mu \mathrm{g} / \mathrm{L}$ & 700 & 160 & Not exceeded & $\mathrm{N} / \mathrm{A}$ & N/A \\
\hline Ethylbenzene & $\mu \mathrm{g} / \mathrm{L}$ & 550 & 61 & Not exceeded & N/A & N/A \\
\hline Isopropylbenzene & $\mu \mathrm{g} / \mathrm{L}$ & 43 & 4.8 & Not exceeded & N/A & N/A \\
\hline Methyl ethyl ketone & $\mu \mathrm{g} / \mathrm{L}$ & 200,000 & 22,000 & Not exceeded & N/A & $\mathrm{N} / \mathrm{A}$ \\
\hline methyl tert-butyl ether & $\mu \mathrm{g} / \mathrm{L}$ & 6,500 & 730 & Not exceeded & $\mathrm{N} / \mathrm{A}$ & N/A \\
\hline m-Xylene plus p-Xylene & $\mu \mathrm{g} / \mathrm{L}$ & ${ }^{6} 240$ & ${ }^{6} 27$ & Not exceeded & N/A & N/A \\
\hline Naphthalene & $\mu \mathrm{g} / \mathrm{L}$ & 170 & 21 & Not exceeded & N/A & N/A \\
\hline o-Xylene & $\mu \mathrm{g} / \mathrm{L}$ & ${ }^{6} 240$ & ${ }^{6} 27$ & Not exceeded & N/A & N/A \\
\hline Styrene & $\mu \mathrm{g} / \mathrm{L}$ & 290 & 32 & Not exceeded & $\mathrm{N} / \mathrm{A}$ & $\mathrm{N} / \mathrm{A}$ \\
\hline Toluene & $\mu \mathrm{g} / \mathrm{L}$ & 560 & 62 & Not exceeded & N/A & N/A \\
\hline Radium-226 & $\mathrm{pCi} / \mathrm{L}$ & ${ }^{7} 5$ & N/A & Not exceeded & N/A & N/A \\
\hline Radium-228 & $\mathrm{pCi} / \mathrm{L}$ & ${ }^{75}$ & N/A & Not exceeded & N/A & N/A \\
\hline
\end{tabular}

${ }^{1}$ For dissolved oxygen, OMZA means outside the mixing zone minimum 24-hour average.

${ }^{2}$ Sampling dates are noted for samples that did not meet the outside mixing zone minimum. However, this field is not applicable for sites that did not meet the outside mixing zone average (which is a computation that uses results from several sampling dates).

${ }^{3}$ Could not compute.

${ }^{4}$ The criteria at a water hardness of $400 \mathrm{mg} / \mathrm{L}$ calcium carbonate are used for water hardnesses above $400 \mathrm{mg} / \mathrm{L}$.

${ }^{5}$ Found in table 35-2 of Ohio Administrative Code (OAC) 3745-1-35 (2017).

${ }^{6} \mathrm{~m}$-Xylene plus o-Xylene plus p-xylene.

${ }^{7}$ Ohio Environmental Protection Agency Drinking water standard (Ra-226 plus Ra-228). 
(OMZA) criteria protective of aquatic life for short- and longterm exposure, respectively. Chemical-specific criteria and exceedances for $\mathrm{pH}$ and constituents that were measured in this investigation are listed in table 14 and contained in Ohio Administrative Code 3745-1-35 (LAWriter Ohio Laws and Rules, 2017b). If a constituent or property is not included in table 14, the OEPA has not established an aquatic life use criterion for that constituent or property at the time of the writing of this report.

The different environments represented by samples from tributaries, lakes, and sites downstream from dams.-Tributaries contain running water and constituent concentrations generally vary with streamflow, with high flows representing a higher component of runoff and low flows representing a larger component of base flow. The lake samples represent the upper surface of the lake (less than or equal to $3.5 \mathrm{ft}$ ) at a localized swimming/recreational area. These sites were chosen for the primary purpose of characterizing water quality in areas where humans are most likely to have water contact. Because water exchange at beach sites may be reduced compared to the main channel or inundated streambed, these samples may not reflect overall lake-water quality. Therefore, the samples do not fully characterize in-lake processes but rather provide preliminary insights into processes that may cause differences in physical properties or constituent concentrations among tributaries, lakes, and sites downstream from dams. For instance, because flow in lakes is slower than that in tributaries, more aquatic biotas grow in the lakes than in the tributaries or below-dam sites. Plants in lakes can uptake nutrients, and photosynthesis by plants can alter constituent concentrations. Profiles provided by the USACE (2018a) of dissolved oxygen concentrations near the dam at each lake indicate that the surface of each of the six study-area lakes is oxygen rich (higher than about $6 \mathrm{mg} / \mathrm{L}$ of dissolved oxygen) throughout the year. Each of the sites downstream from the dams at Atwood, Leesville, Clendening, Piedmont, and Senecaville Lakes represent water removed from a fixed point near the bottom of the lake. Water released from Tappan Lake is a mix of water from near the bottom of the lake mixed with water from a fixed point near the top of the lake $(6 \mathrm{ft}$ below surface of summer pool or $1 \mathrm{ft}$ below surface of winter pool) (Jean Diedel, USACE, written commun., 2017). Because flows are regulated at these sites, higher flows are not necessarily the result of runoff, because water can be released from the dam at any time. Thus, constituent concentrations may not be related to streamflow at sampling sites downstream from dams.

Profiles provided by the USACE (2018a) at each lake indicate that dissolved oxygen is depleted (less than $3 \mathrm{mg} / \mathrm{L}$ ) at the bottom of each lake in the lacustrine zone near the dam from about May to about mid-September or mid-October. Oxygen depletion is a function of lake temperature and decay processes. In summer when the lake surface warms, warmer surface water does not mix with the cooler water at the bottom of the lake near the dam (USACE, 2018a). Decay of algae and other aquatic biota that have settled to the bottom of the lake consumes oxygen and causes the oxygen-depleted zone. In the fall, as the lake surface cools, waters mix again and dissolved oxygen at the bottom of the lake is replenished (USGS, variously dated, p. 4-13).

Several constituents, particularly nitrogen, manganese, iron, and sulfur, behave differently depending on whether oxygen is present or absent because of oxidation-reduction (redox) reactions. Reduction reactions are taking place at depth within the lakes, where dissolved oxygen is not replenished during the summer. During these reactions, microbes can transfer electrons from dissolved organic carbon sequentially to the following "electron acceptors" (listed in order or preference): dissolved oxygen, nitrate, manganese(IV), iron(III), sulfate, and carbon dioxide. After one electron acceptor is consumed, microbes then use the next most favorable electron acceptor and the water becomes more "reducing." Redox conditions were calculated for samples from each below-dam site, using concentrations of dissolved oxygen, nitrate plus nitrite, manganese, iron, sulfate, and sulfide (table 15). Classification criteria and redox reaction formulas are described by Jurgens and others (2009). In reducing conditions, dissolved oxygen concentrations are less than $0.5 \mathrm{mg} / \mathrm{L}$ and the following transformations occur:

- nitrate-reducing conditions - nitrate is converted to ammonia and nitrogen gas;

- manganese-reducing conditions-manganese(IV), a solid, is converted to manganese(III) and dissolves into water;

- iron-reducing conditions-iron(III), a solid, is converted to iron(II) and dissolves into water;

- sulfate reducing conditions - sulfate is converted to sulfide, which can be in the form of hydrogen sulfide gas; and

- carbon dioxide reducing conditions - carbon dioxide gas and hydrogen ions in water are converted to methane.

Although the samples downstream from dams are indicators of lake bottom redox environment, the samples are aerated somewhat upon release from the dam and, thus, may underestimate the strength of reducing processes occurring at depth in the lakes during late spring and summer.

In the following paragraphs, spatial variations in concentrations or levels of constituents and properties, if observed, are discussed by type because spatial variation caused by identifiable influences (such as aquatic biota, redox reactions, and geology) can be confounding factors when interpreting statistical relations among water quality and human activities, as discussed later in the report. Aquatic life use criteria, where pertinent, also are discussed to provide context for observed concentrations or levels of constituents and properties. Median values were determined to differ at a statistically significant level $(p$-value $<0.05)$ between mine-impacted and non-mine-impacted sites (figs. 11A-11U), and samples with a component of brine and samples containing no brine are noted (figs. 12A-12G). 
Table 15. Redox environment classification for sites downstream from dams, Muskingum River watershed, $2015-16$.

[USGS, U.S. Geological Survey; $\mathrm{O}_{2}$, oxic; $\mathrm{O}_{2}-\mathrm{Mn}(\mathrm{IV})$, mixed oxic and manganese-reducing; $\mathrm{O}_{2}$-Fe(III), mixed oxic and iron-reducing]

\begin{tabular}{|c|c|c|c|c|}
\hline Lake & Below-dam site & USGS station number & Sample date & Redox process \\
\hline \multirow[t]{6}{*}{ Atwood } & Indian Fork below Atwood Dam near New Cumberland, Ohio & 03121500 & $4 / 13 / 2015$ & $\mathrm{O}_{2}$ \\
\hline & Indian Fork below Atwood Dam near New Cumberland, Ohio & 03121500 & $6 / 1 / 2015$ & $\mathrm{O}_{2}-\mathrm{Mn}(\mathrm{IV})$ \\
\hline & Indian Fork below Atwood Dam near New Cumberland, Ohio & 03121500 & $8 / 17 / 2015$ & $\mathrm{O}_{2}-\mathrm{Fe}(\mathrm{III})$ \\
\hline & Indian Fork below Atwood Dam near New Cumberland, Ohio & 03121500 & $10 / 19 / 2015$ & $\mathrm{O}_{2}$ \\
\hline & Indian Fork below Atwood Dam near New Cumberland, Ohio & 03121500 & $3 / 15 / 2016$ & $\mathrm{O}_{2}$ \\
\hline & Indian Fork below Atwood Dam near New Cumberland, Ohio & 03121500 & $5 / 24 / 2016$ & $\mathrm{O}_{2}-\mathrm{Mn}(\mathrm{IV})$ \\
\hline \multirow[t]{6}{*}{ Leesville } & McGuire Creek near Leesville, Ohio & 03120500 & $4 / 13 / 2015$ & $\mathrm{O}_{2}$ \\
\hline & McGuire Creek near Leesville, Ohio & 03120500 & $5 / 27 / 2015$ & $\mathrm{O}_{2}-\mathrm{Mn}(\mathrm{IV})$ \\
\hline & McGuire Creek near Leesville, Ohio & 03120500 & $8 / 11 / 2015$ & $\mathrm{O}_{2}-\mathrm{Fe}(\mathrm{III})$ \\
\hline & McGuire Creek near Leesville, Ohio & 03120500 & $10 / 20 / 2015$ & $\mathrm{O}_{2}$ \\
\hline & McGuire Creek near Leesville, Ohio & 03120500 & $3 / 15 / 2016$ & $\mathrm{O}_{2}$ \\
\hline & McGuire Creek near Leesville, Ohio & 03120500 & $5 / 10 / 2016$ & $\mathrm{O}_{2}-\mathrm{Mn}(\mathrm{IV})$ \\
\hline \multirow[t]{6}{*}{ Tappan } & Little Stillwater Creek below Tappan Dam at Tappan, Ohio & 03128500 & $4 / 14 / 2015$ & $\mathrm{O}_{2}$ \\
\hline & Little Stillwater Creek below Tappan Dam at Tappan, Ohio & 03128500 & $5 / 27 / 2015$ & $\mathrm{O}_{2}-\mathrm{Mn}(\mathrm{IV})$ \\
\hline & Little Stillwater Creek below Tappan Dam at Tappan, Ohio & 03128500 & $8 / 11 / 2015$ & $\mathrm{O}_{2}-\mathrm{Mn}(\mathrm{IV})$ \\
\hline & Little Stillwater Creek below Tappan Dam at Tappan, Ohio & 03128500 & $10 / 20 / 2015$ & $\mathrm{O}_{2}$ \\
\hline & Little Stillwater Creek below Tappan Dam at Tappan, Ohio & 03128500 & $3 / 15 / 2016$ & $\mathrm{O}_{2}-\mathrm{Mn}(\mathrm{IV})$ \\
\hline & Little Stillwater Creek below Tappan Dam at Tappan, Ohio & 03128500 & $5 / 10 / 2016$ & $\mathrm{O}_{2}-\mathrm{Mn}(\mathrm{IV})$ \\
\hline \multirow[t]{6}{*}{ Clendening } & Brushy Fork near Tippecanoe, Ohio & 03126910 & $4 / 15 / 2015$ & $\mathrm{O}_{2}$ \\
\hline & Brushy Fork near Tippecanoe, Ohio & 03126910 & $5 / 27 / 2015$ & $\mathrm{O}_{2}-\mathrm{Mn}(\mathrm{IV})$ \\
\hline & Brushy Fork near Tippecanoe, Ohio & 03126910 & $8 / 12 / 2015$ & $\mathrm{O}_{2}-\mathrm{Mn}(\mathrm{IV})$ \\
\hline & Brushy Fork near Tippecanoe, Ohio & 03126910 & $10 / 22 / 2015$ & $\mathrm{O}_{2}$ \\
\hline & Brushy Fork near Tippecanoe, Ohio & 03126910 & $3 / 23 / 2016$ & $\mathrm{O}_{2}$ \\
\hline & Brushy Fork near Tippecanoe, Ohio & 03126910 & $5 / 17 / 2016$ & $\mathrm{O}_{2}-\mathrm{Mn}(\mathrm{IV})$ \\
\hline \multirow[t]{6}{*}{ Piedmont } & Stillwater Creek below Piedmont Dam near Piedmont, Ohio & 401139081125400 & $4 / 20 / 2015$ & $\mathrm{O}_{2}$ \\
\hline & Stillwater Creek below Piedmont Dam near Piedmont, Ohio & 401139081125400 & $6 / 4 / 2015$ & $\mathrm{O}_{2}-\mathrm{Mn}(\mathrm{IV})$ \\
\hline & Stillwater Creek below Piedmont Dam near Piedmont, Ohio & 401139081125400 & $8 / 20 / 2015$ & $\mathrm{O}_{2}-\mathrm{Mn}(\mathrm{IV})$ \\
\hline & Stillwater Creek below Piedmont Dam near Piedmont, Ohio & 401139081125400 & $10 / 26 / 2015$ & $\mathrm{O}_{2}$ \\
\hline & Stillwater Creek below Piedmont Dam near Piedmont, Ohio & 401139081125400 & $3 / 29 / 2016$ & $\mathrm{O}_{2}$ \\
\hline & Stillwater Creek below Piedmont Dam near Piedmont, Ohio & 401139081125400 & $5 / 19 / 2016$ & $\mathrm{O}_{2}-\mathrm{Mn}(\mathrm{IV})$ \\
\hline \multirow[t]{6}{*}{ Senecaville } & Seneca Fork below Senecaville Dam near Senecaville, Ohio & 03141500 & $4 / 21 / 2015$ & $\mathrm{O}_{2}$ \\
\hline & Seneca Fork below Senecaville Dam near Senecaville, Ohio & 03141500 & $5 / 28 / 2015$ & $\mathrm{O}_{2}-\mathrm{Mn}(\mathrm{IV})$ \\
\hline & Seneca Fork below Senecaville Dam near Senecaville, Ohio & 03141500 & $8 / 18 / 2015$ & $\mathrm{O}_{2}-\mathrm{Mn}(\mathrm{IV})$ \\
\hline & Seneca Fork below Senecaville Dam near Senecaville, Ohio & 03141500 & $10 / 26 / 2015$ & $\mathrm{O}_{2}-\mathrm{Mn}(\mathrm{IV})$ \\
\hline & Seneca Fork below Senecaville Dam near Senecaville, Ohio & 03141500 & $3 / 23 / 2016$ & $\mathrm{O}_{2}$ \\
\hline & Seneca Fork below Senecaville Dam near Senecaville, Ohio & 03141500 & $5 / 17 / 2016$ & $\mathrm{O}_{2}-\mathrm{Mn}(\mathrm{IV})$ \\
\hline
\end{tabular}



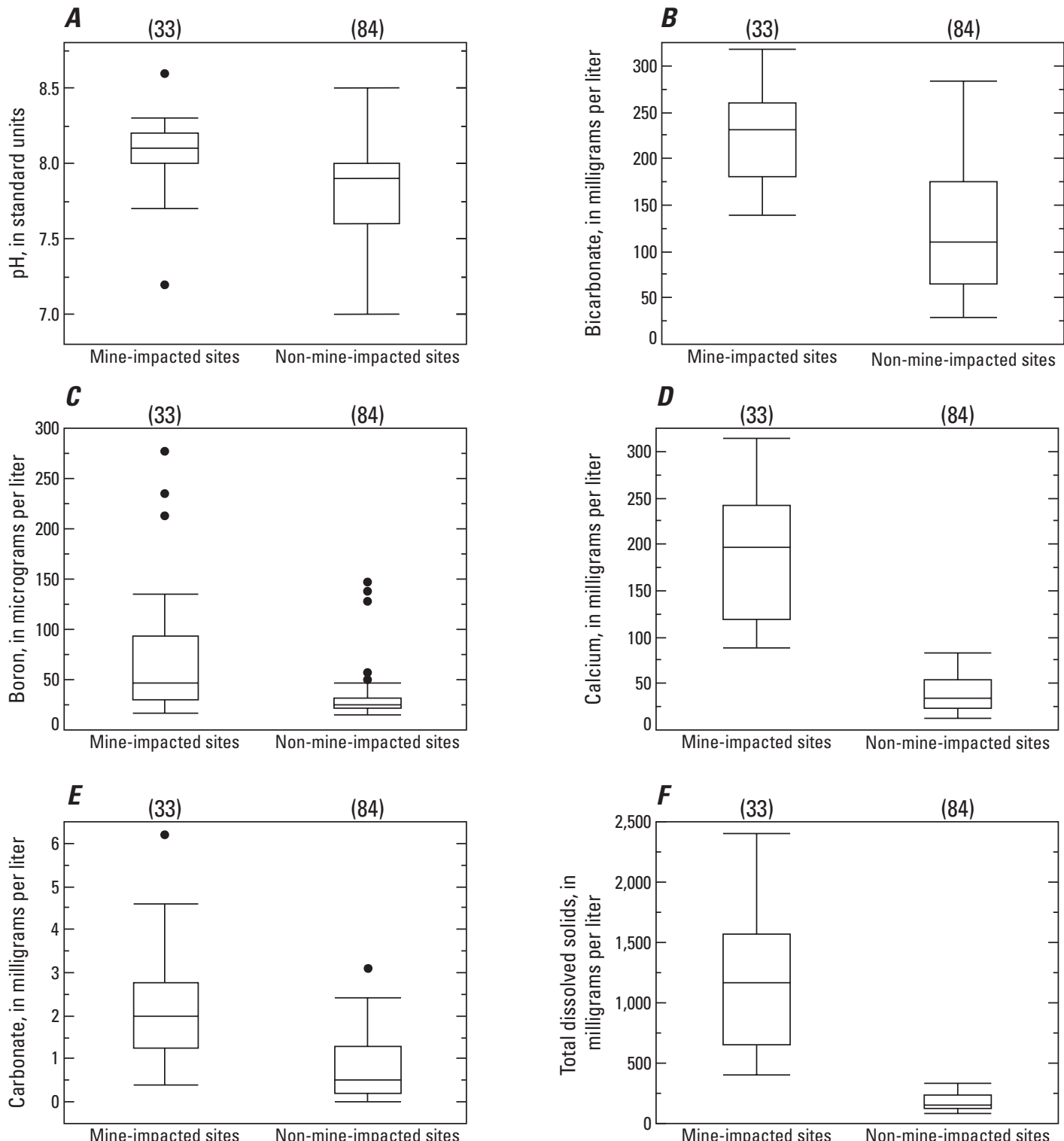

EXPLANATION

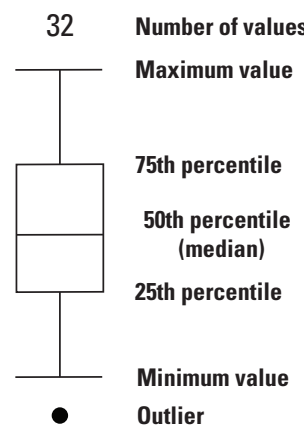
* Differences in median concentrations of iron $(H)$ and organic carbon $(M)$ between mine-impacted and non-mine-impacted sites are less than the maximum differences in concentration between quality-control replicate pair samples (Covert and others, 2018), suggesting that the iron and organic carbon concentration differences noted in the boxplot, although statistically significant, may be caused by laboratory variability rather than by chemical differences between mine-impacted and non-mine-impacted sites.

Figure 11. Concentrations or levels of constituents and properties that differed at a statistically significant level ( $p$-value $<0.05$ ) between mine-impacted and non-mine-impacted sites (stream sites only), Muskingum watershed, Ohio, April 2015 through May 2016. $A$, pH; $B$, bicarbonate; $C$, boron; $D$, calcium; $E$, carbonate; $F$, total dissolved solids; $G$, fluoride; $H$, iron; $I$, magnesium; $J$, manganese; $K$, lithium; $L$, nitrate plus nitrite; $M$, dissolved organic carbon; $N$, potassium; $O$, silica; $P$, sodium; $Q$, specific conductance; $R$, strontium; $S$, sulfate; $T$, suspended sediment; and $U$, total dissolved nitrogen. 

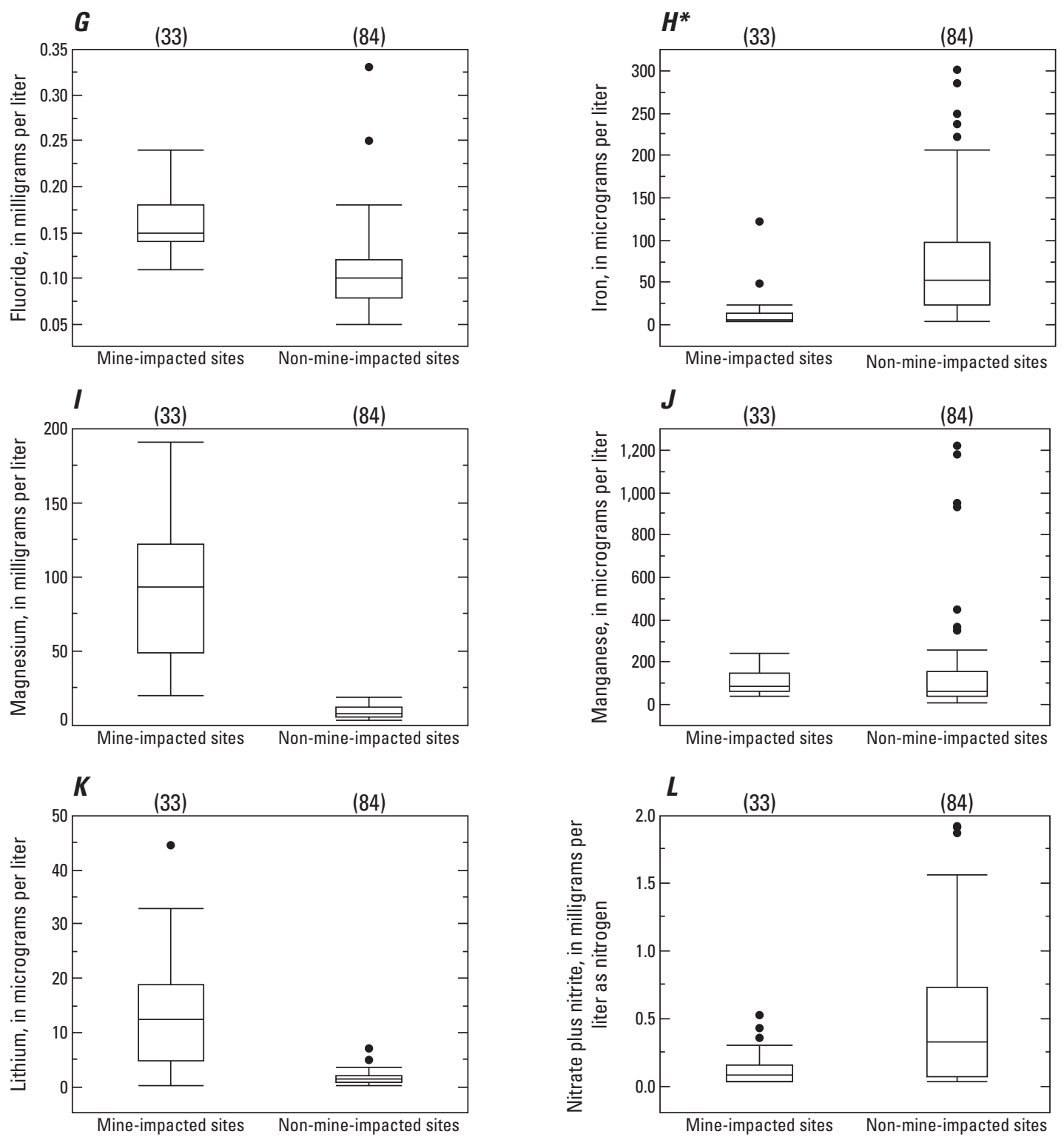

\section{EXPLANATION}
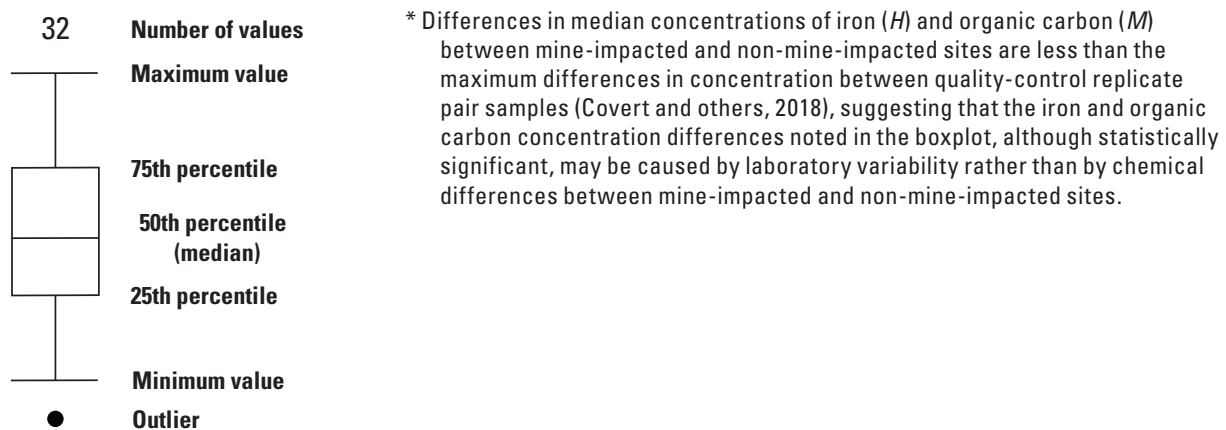

Figure 11. Concentrations or levels of constituents and properties that differed at a statistically significant level ( $p$-value $<0.05$ ) between mine-impacted and non-mine-impacted sites (stream sites only), Muskingum watershed, Ohio, April 2015 through May 2016. $A$, pH; $B$, bicarbonate; $C$, boron; $D$, calcium; $E$, carbonate; $F$, total dissolved solids; $G$, fluoride; $H$, iron; I, magnesium; $J$, manganese; $K$, lithium; $L$, nitrate plus nitrite; $M$, dissolved organic carbon; $N$, potassium; $O$, silica; $P$, sodium; $Q$, specific conductance; $R$, strontium; $S$, sulfate; $T$, suspended sediment; and $U$, total dissolved nitrogen.-Continued 

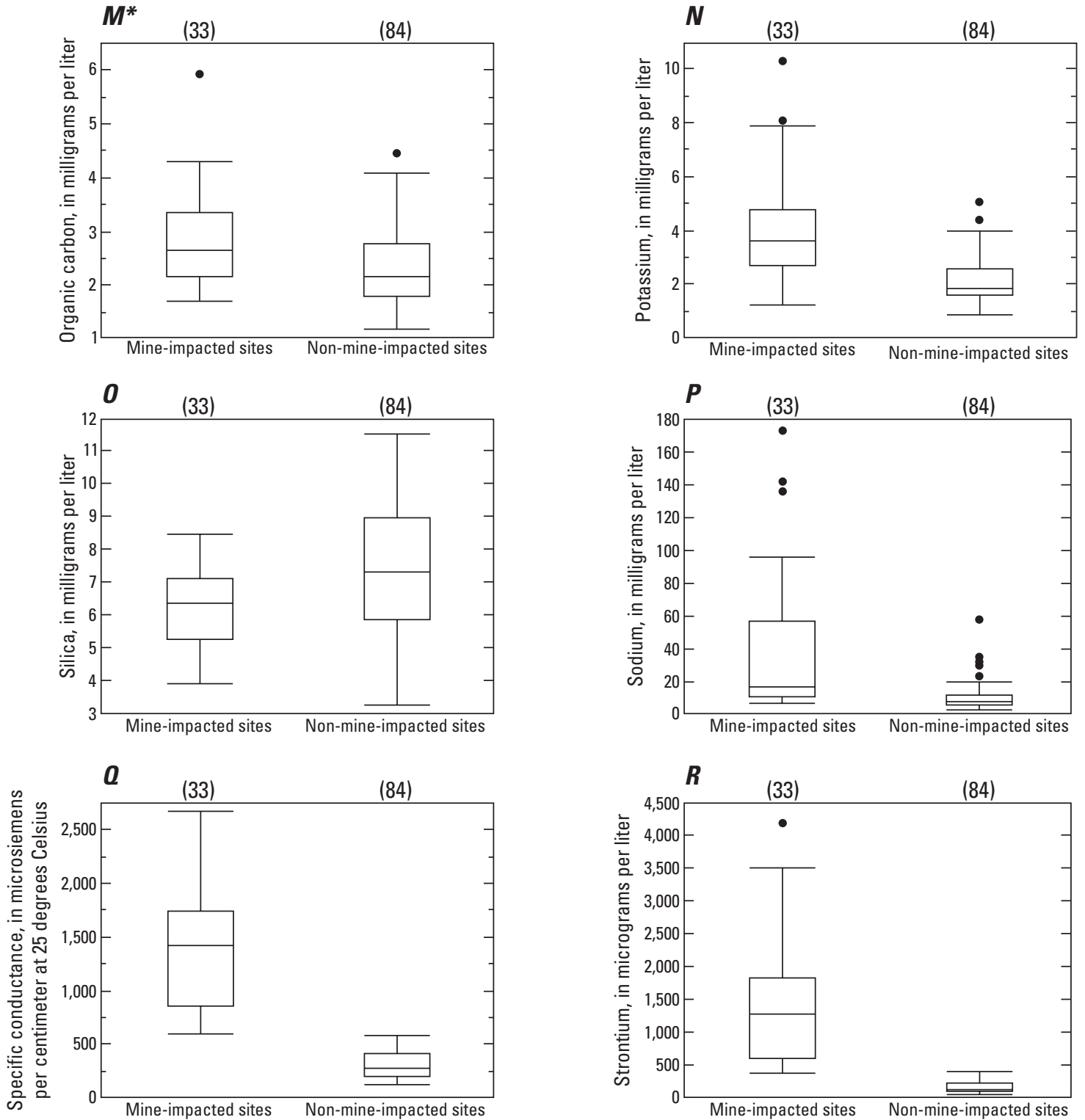

\section{EXPLANATION}

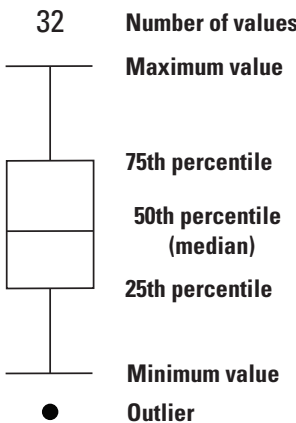

* Differences in median concentrations of iron $(H)$ and organic carbon $(M)$ between mine-impacted and non-mine-impacted sites are less than the maximum differences in concentration between quality-control replicate pair samples (Covert and others, 2018), suggesting that the iron and organic carbon concentration differences noted in the boxplot, although statistically significant, may be caused by laboratory variability rather than by chemical differences between mine-impacted and non-mine-impacted sites.

Figure 11. Concentrations or levels of constituents and properties that differed at a statistically significant level ( $p$-value $<0.05$ ) between mine-impacted and non-mine-impacted sites (stream sites only), Muskingum watershed, Ohio, April 2015 through May 2016. $A, \mathrm{pH} ; B$, bicarbonate; $C$, boron; $D$, calcium; $E$, carbonate; $F$, total dissolved solids; $G$, fluoride; $H$, iron; $I$, magnesium; $J$, manganese; $K$, lithium; $L$, nitrate plus nitrite; $M$, dissolved organic carbon; $N$, potassium; $O$, silica; $P$, sodium; $Q$, specific conductance; $R$, strontium; $S$, sulfate; $T$, suspended sediment; and $U$, total dissolved nitrogen.-Continued 

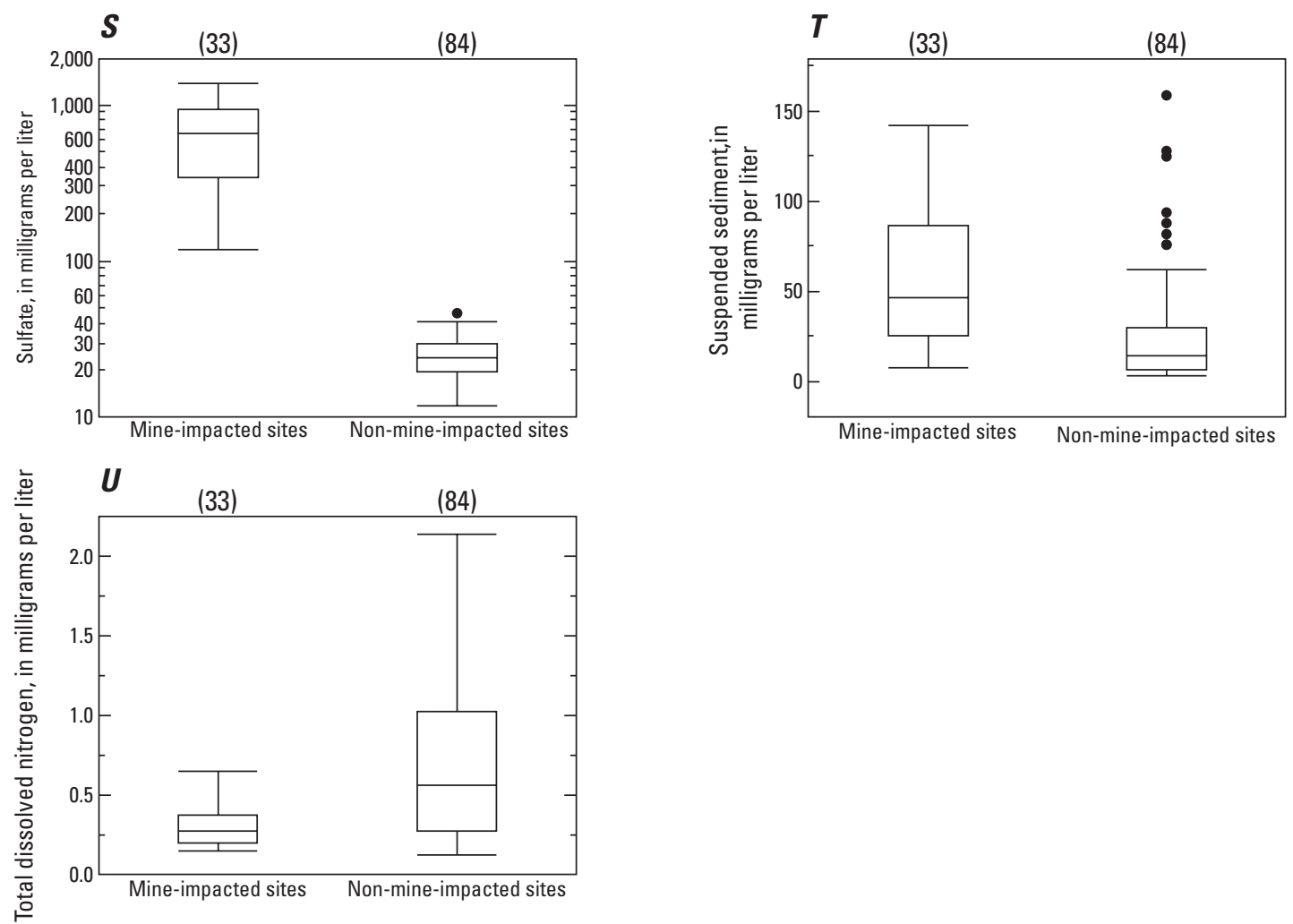

\section{EXPLANATION}

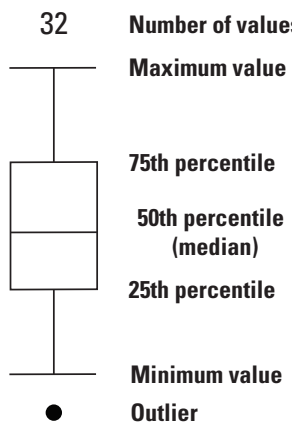

* Differences in median concentrations of iron $(H)$ and organic carbon $(M)$ between mine-impacted and non-mine-impacted sites are less than the maximum differences in concentration between quality-control replicate pair samples (Covert and others, 2018), suggesting that the iron and organic carbon concentration differences noted in the boxplot, although statistically significant, may be caused by laboratory variability rather than by chemical differences between mine-impacted and non-mine-impacted sites.

Figure 11. Concentrations or levels of constituents and properties that differed at a statistically significant level ( $p$-value $<0.05$ ) between mine-impacted and non-mine-impacted sites (stream sites only), Muskingum watershed, Ohio, April 2015 through May 2016. A, pH; $B$, bicarbonate; $C$, boron; $D$, calcium; $E$, carbonate; $F$, total dissolved solids; $G$, fluoride; $H$, iron; $I$, magnesium; $J$, manganese; $K$, lithium; $L$, nitrate plus nitrite; $M$, dissolved organic carbon; $N$, potassium; $O$, silica; $P$, sodium; $Q$, specific conductance; $R$, strontium; $S$, sulfate; $T$, suspended sediment; and $U$, total dissolved nitrogen.-Continued 

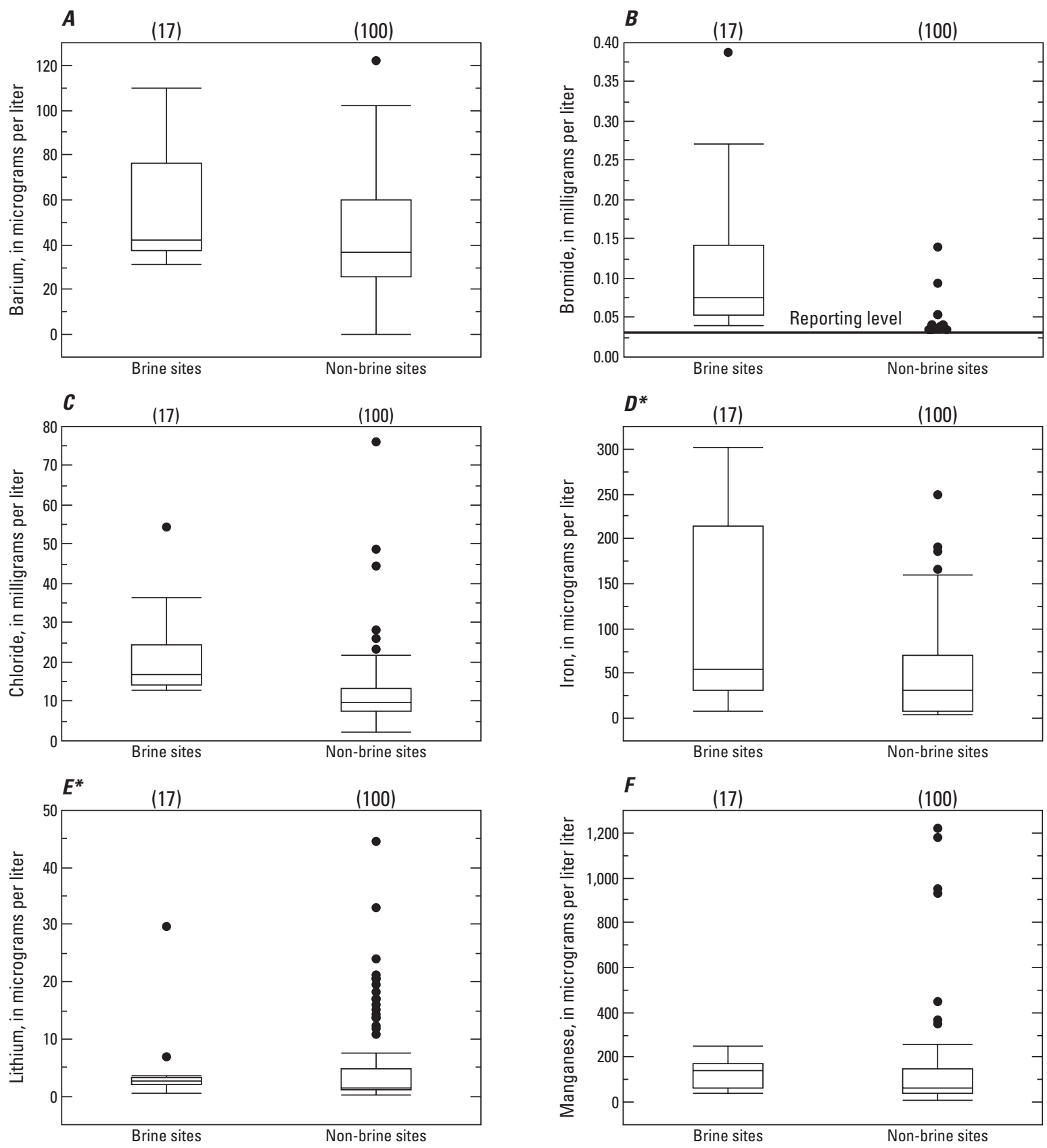

EXPLANATION

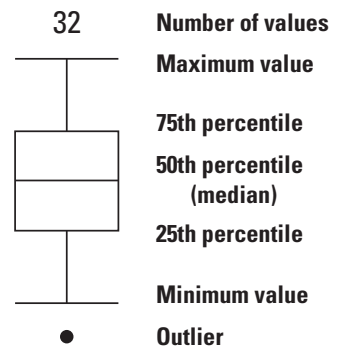

* Differences in median concentrations of iron $(D)$ and lithium $(E)$ between samples with and without a component of brine are less than the maximum differences in concentration between quality-control replicate pair samples (Covert and others, 2018), suggesting that the iron and lithium concentration differences noted in the boxplot, although statistically significant, may be caused by laboratory variability rather than by chemical differences between samples with and without a brine component.

Figure 12. Concentrations of constituents that differed at a statistically significant level ( $p$-value $<0.05$ ) for samples (stream sites only) with and without a component of brine, Muskingum River watershed, Ohio, April 2015 through May 2016. $A$, barium; $B$, bromide; $C$, chloride; $D$, iron; $E$, lithium; $F$, manganese; and $G$, sodium. 


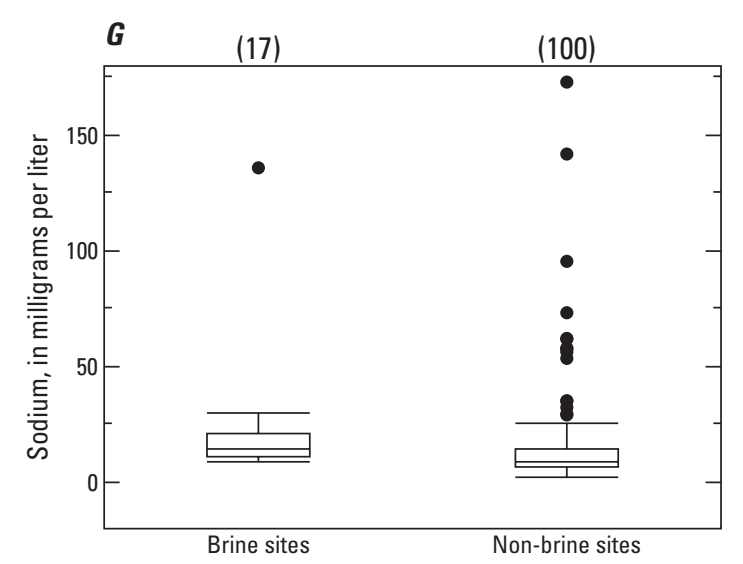

EXPLANATION

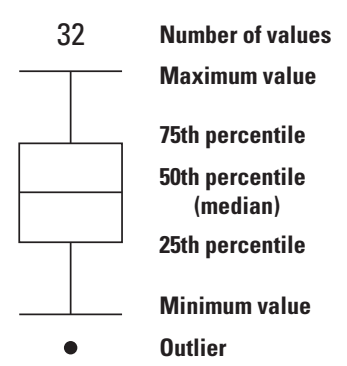

* Differences in median concentrations of iron $(D)$ and lithium $(E)$ between samples with and without a component of brine are less than the maximum differences in concentration between quality-control replicate pair samples (Covert and others, 2018), suggesting that the iron and lithium concentration differences noted in the boxplot, although statistically significant, may be caused by laboratory variability rather than by chemical differences between samples with and without a brine component.

Figure 12. Concentrations of constituents that differed at a statistically significant level ( $p$-value $<0.05$ ) for samples (stream sites only) with and without a component of brine, Muskingum River watershed, Ohio, April 2015 through May 2016. A, barium; $B$, bromide; $C$, chloride; $D$, iron; $E$, lithium; $F$, manganese; and $G$, sodium.-Continued

\section{$\mathrm{pH}$}

In the samples collected for this study, $\mathrm{pH}$ ranged from 7 (neutral) to 8.9 (alkaline) (table 8 and fig. 2-5). As a result, $\mathrm{pH}$ met the aquatic life use criteria at all sites (table 14). Contrary to typical conditions reflected in ODNR-DMRM chemical water-quality criteria for mine drainage impacts (table 10), the median $\mathrm{pH}$ of mine-impacted sites was higher than that of non-mine-impacted sites (fig. 11A). The apparent absence of acidic waters in the coal-mined drainage basins in the study area might be because the mined lands were reclaimed, acidic mine drainage is treated prior to discharge, or the abundant limestone layers in the local bedrock, particularly in the Monongahela Group, are buffering the water.
For all drainage basins with in-lake samples (Atwood, Tappan, Piedmont, and Senecaville), median $\mathrm{pH}$ (8.4) in nearsurface lake samples was higher than in samples collected in either upstream sites (median of 8.0) or samples collected from below the dam (median of 7.8) (table 8 and fig. 2-5). This result is likely due to higher photosynthetic activity near the water surface in the lakes than in either tributary or belowdam sites. Photosynthesis by aquatic plants and phytoplankton consumes carbon dioxide during the daytime, when samples were collected, which causes $\mathrm{pH}$ to increase (USGS, variously dated). The $\mathrm{pH}$ of water controls the solubility of many chemical constituents (Hem, 1985).

\section{Alkalinity}

Alkalinity is a measure of the ability of water to neutralize acid (Hem, 1985, p. 105). Alkalinity values in the study area seemed to vary depending on the underlying geology. Median alkalinities from samples collected in Atwood and Leesville drainage basins, at the north end of the study area, were generally less than alkalinity values from samples collected in the Piedmont and Senecaville drainage basins at the south end of the study area (fig. 2-9). Median alkalinity values for these drainage basins were as follows: Atwood (56.1 mg/L), Leesville (65.9 mg/L), Piedmont (141 mg/L), and Senecaville $(186 \mathrm{mg} / \mathrm{L})$ (data not in report). No Monongahela Group bedrock lies within the Atwood and Leesville drainage basins, whereas the Monongahela Group underlies a large part of the Piedmont and Senecaville drainage basins (fig. 5). The Monongahela Group contains proportionally more limestone - a carbonate-rich rock known for its acid-buffering capacity - than the other bedrock units in the area (Sedam and Francy, 1993). Tributaries to Tappan and Clendening Lakes with the highest alkalinity values (minimum concentrations exceeding $100 \mathrm{mg} / \mathrm{L}$ ) - Standingstone Fork above Tappan Lake, Ohio; Clear Fork above Tappan Lake, Ohio; and Brushy Fork above Clendening, Ohio) (fig. 2-9)—were collected from tributaries that drain from the eastern end of the drainage basins, where Monongahela Group bedrock is located.

Alkalinity values also seemed to be affected by in-lake processes. Median alkalinity values for lake sites $(97.65 \mathrm{mg} / \mathrm{L})$ and sites downstream from dams $(96.5 \mathrm{mg} / \mathrm{L})$ were less than the median alkalinity value at the upstream sites $(120 \mathrm{mg} / \mathrm{L})$ (table 8), suggesting that in-lake processes might be decreasing alkalinity. A decrease in alkalinity values is particularly evident in the Senecaville Lake drainage basin (fig. 2-9), where upstream tributaries have a median alkalinity of $197 \mathrm{mg} / \mathrm{L}$ compared with median alkalinities of 119 and $125 \mathrm{mg} / \mathrm{L}$ at the lake site and downstream from the dam, respectively. Greater photosynthesis and resulting higher consumption of carbon dioxide in lakes compared to streams, could potentially reduce bicarbonate concentrations (Hem, 1985 ) and, thus, reduce alkalinity concentrations in lakes relative to streams. 


\section{Dissolved Oxygen}

Concentrations of dissolved oxygen in all samples ranged from 2.6 to $14 \mathrm{mg} / \mathrm{L}$ (table 8). With one exception, the minimum dissolved oxygen concentrations at all sites occurred at less-than-median streamflows; maximum dissolved oxygen concentrations generally occurred at higher-than-median streamflows (table 13 and fig. 2-4). However, separating the effects of streamflow on dissolved oxygen concentrations from the effects of temperature on dissolved oxygen concentrations is difficult. Cold water can hold more dissolved oxygen than warm water (USGS, 2017c). In the study area, dissolved oxygen concentrations are negatively correlated to water temperature at stream, lake, and gage (below-dam) sites at statistically significant levels (Spearman's rank correlation coefficient of $-0.63,-0.70$, and -0.92 , respectively). The coldest water temperatures were generally measured in March, which coincided with higher streamflows; warmest temperatures were generally measured in June and August, when streamflows were low.

The lowest dissolved oxygen concentration $(2.6 \mathrm{mg} / \mathrm{L})$ was measured below the dam at Clendening (Brushy Fork near Tippecanoe, Ohio) in August 2015 (fig. 2-4) and was less than the minimum OMZM required for aquatic life $(<4.0 \mathrm{mg} / \mathrm{L})$ (table 14). The sampling frequency for this investigation was not adequate to calculate the OMZA criterion for dissolved oxygen, which is a 24-hour average. Dissolved oxygen concentrations in all other samples were higher than or equal to $5.1 \mathrm{mg} / \mathrm{L}$, meeting aquatic life use criteria. Because dissolved oxygen is, in part, a product of photosynthesis by aquatic biota (a light-dependent process), dissolved oxygen concentrations typically begin to increase at sunrise, gradually climb throughout the day, and then start to decline near sunset (Shi and others, 2003). The low dissolved oxygen concentration $(2.6 \mathrm{mg} / \mathrm{L})$ at Brushy Fork near Tippecanoe, Ohio, probably cannot be attributed to diurnal fluctuations because the sample was collected at $3 \mathrm{p}$.m. Rather, water released from near the bottom of Clendening Lake in August 2015 was most likely depleted in oxygen because of elevated temperature (19.8 degrees Celsius - the highest water temperature measured at this site) and oxygen-depleted conditions at depth in the lake as confirmed by typical dissolved oxygen profiles available from the USACE (2018a). Classification of redox processes based on dissolved oxygen and other chemical constituent concentrations indicates that conditions in Brushy Fork near Tippecanoe, Ohio, on August 12, 2015, were manganese-reducing conditions (table 15).

\section{Specific Conductance}

Specific conductance concentrations in the study area ranged from 117 to $2,680 \mu \mathrm{S} / \mathrm{cm}$ (table 8). Significantly higher specific conductance concentrations occurred at sites identified as mine impacted (median of $1,420 \mu \mathrm{S} / \mathrm{cm}$ ) compared to non-mine-impacted sites (median of $272 \mu \mathrm{S} / \mathrm{cm}$ ) (fig. $11 Q$ and fig. 2-3). Because specific conductance is continuously monitored at water-quality gages at 14 sites in the study area (fig. 1), major anions influencing specific conductance were assessed using a linear model (figs. 13A-13C). At mineimpacted sites, a strong linear relation existed between specific conductance and sulfate concentrations $\left(R^{2}\right.$ of about 0.98$)$

(fig. 13A). Even mine-impacted sites with a brine component best fit this model because (1) sulfate concentrations (median of $647 \mathrm{mg} / \mathrm{L}$ ) were much higher than chloride concentrations at mine-impacted sites (maximum of $26.1 \mathrm{mg} / \mathrm{L}$ ), and (2) sulfate, because of its higher charge, has a higher ionic strength than an equivalent concentration of either chloride or bicarbonate (Hem, 1985, plate 1). The strong influence of sulfate on specific conductance at mine-impacted sites would make any specific-conductance increase caused by a small addition of chloride to these streams difficult to notice. However, a brine spill (if one were to occur on a mine-impacted stream) would likely result in a chloride concentration higher than $10,000 \mathrm{mg} / \mathrm{L}$ (Blondes and others, 2017), which would cause a noticeable increase in specific conductance. A strong linear relation existed between specific conductance and bicarbonate concentrations $\left(R^{2}\right.$ of 0.87$)$ observed in the other (non-mineimpacted, non-brine-component) stream, lake, and below-dam samples (fig. 13B).

\section{Total Dissolved Solids}

Concentrations of total dissolved solids ranged from 77 to $2,400 \mathrm{mg} / \mathrm{L}$ (table 8), with the highest concentrations occurring at Standingstone Fork above Tappan Lake, Ohio, and Brushy Fork above Clendening Lake, Ohio. The average total dissolved solids values $(1,527.5$ and $1,738 \mathrm{mg} / \mathrm{L}$, respectively) for these two sites exceeded the aquatic life use OMZA criterion (1,500 mg/L) (table 14). Brushy Fork above Clendening Lake, Ohio, is designated as limited warmwater habitat and is exempted for total dissolved solids because of historical mining (OEPA, 2017a). Both sites are mineimpacted sites (table 11). Total dissolved solids concentrations were much higher for mine-impacted sites throughout the study area-median concentrations more than seven times higher - than for non-mine-impacted sites (fig. $11 F$ and fig. 2-8).

\section{Major lons}

The bicarbonate- and sulfate-type waters discussed earlier in the report were identified based on the percentages of major ions in samples (fig. 8). Major ions, for the most part, are derived from weathering of rock and sediment. Concentrations of major ions are shown in the boxplots in figures 2-10 through 2-21. No State aquatic life use criteria are established for major ions.

Bicarbonate concentrations ranged from 29.5 to $317 \mathrm{mg} / \mathrm{L}$ (table 8) and were generally higher during low flow than during high flow conditions (table 13). Bicarbonate, a major contributor to alkalinity, displayed the same pattern of spatial variations in concentration (fig. 2-11) as alkalinity 

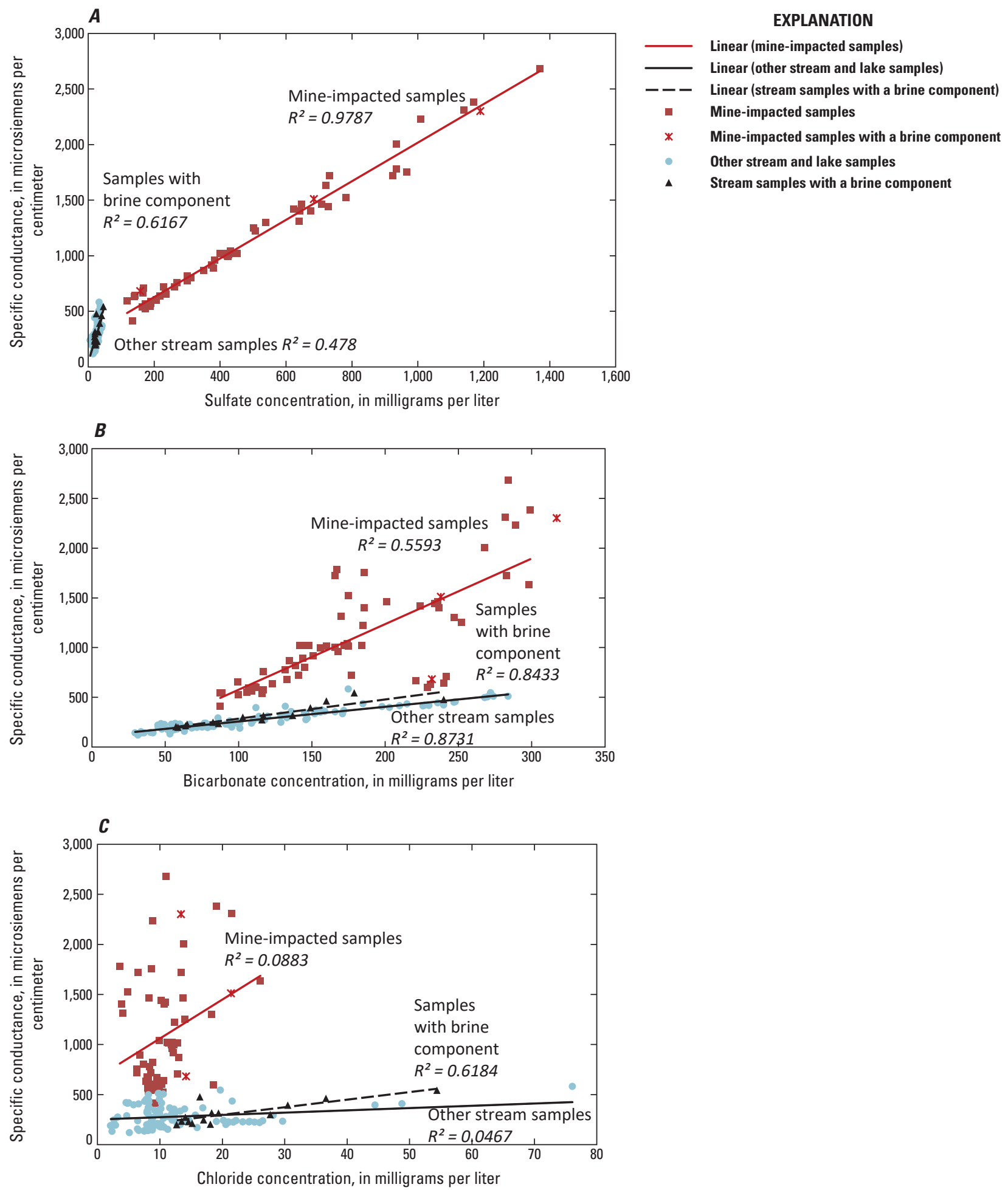

Figure 13. Specific conductance as a function of anion concentration, Muskingum River watershed, 0hio, 2015-16. A, sulfate; $B$, bicarbonate; and $C$, chloride. 
(fig. 2-9). The pattern is as follows: (1) lower concentrations in Atwood Lake and Leesville Lake drainage basins, where the Monongahela Group bedrock is absent and higher concentrations in Piedmont and Senecaville Lakes, where the Monongahela Group bedrock is present; and (2) lower concentrations in lakes (median of $115.5 \mathrm{mg} / \mathrm{L}$ ) and downstream of dams (median $116.5 \mathrm{mg} / \mathrm{L}$ ) relative to upstream sites (median of $146 \mathrm{mg} / \mathrm{L}$ ) (table 8), indicating that in-lake processes such as photosynthesis may reduce bicarbonate concentrations. Bicarbonate concentrations also were higher at mine-impacted sites than at non-mine-impacted sites (fig. 11B).

Sulfate concentrations ranged from 6.2 to $1,370 \mathrm{mg} / \mathrm{L}$ (table 8), with the highest concentration occurring at Brushy Fork above Clendening Lake, Ohio. Sulfate concentrations were elevated at mine-impacted sites relative to non-mineimpacted sites (fig. $11 S$ and fig. 2-19). Sulfate is released from coal and overburden rocks during mining when iron sulfide minerals (usually pyrite) are brought to land surface and exposed to oxygen (or are exposed to air in an underground mine) and sulfide is oxidized to sulfate. In the Tappan Lake drainage basin, sulfide concentrations were elevated at mineimpacted sites relative to other sites (fig. 2-18).

Because chloride is the dominant anion in oil-field brines (fig. 8) and does not readily sorb to or react with sediments, chloride concentrations would become elevated if brine were released to a stream. Chloride concentrations in the study area ranged from 2.12 to $76.1 \mathrm{mg} / \mathrm{L}$ (table 8). Although no State aquatic life use criteria are established for chloride (table 14), concentrations in the study area were less than the national recommended water-quality criteria for aquatic life of $230 \mathrm{mg} / \mathrm{L}$ (U.S. Environmental Protection Agency, 2017) - the concentration at which chloride is likely to harm freshwater plant and animal life with chronic (long-term) exposure.

The highest concentration of chloride $(76.1 \mathrm{mg} / \mathrm{L})$ occurred at Indian Fork at Dellroy, Ohio, in the Atwood Lake drainage basin. This sample plotted not as a brine on figure $10 B$ but between the mixing curves, in the intermediate zone that typically represents samples affected by septic or animal waste, wastewater treatment plant effluent (of which two are in the drainage basin), or water from field tiles. At higher flows, samples at this site plotted in an area closer to the road salt mixing curve. Chloride concentrations in the Atwood Lake drainage basin (median of $21.4 \mathrm{mg} / \mathrm{L}$ ) were higher than chloride concentrations in other lake drainage basins in the study area (median $9.89 \mathrm{mg} / \mathrm{L}$ ) (fig. 2-17). Multiple samples from three sites in the Atwood Lake drainage basin-Unnamed tributary near Dellroy, Ohio; Elliot Run near Dellroy, Ohio; and Willow Run near Dellroy, Ohio-were identified as having a component of brine based on chloride concentrations and $\mathrm{Cl}: \mathrm{Br}$ ratios (see "Sources of Salinity" section). Overall, median chloride concentrations at mineimpacted sites were not statistically different from non-mineimpacted sites, but median chloride concentrations with a component of brine were higher and statistically different from those at non-brine sites (fig. 12C).
Concentrations of the cations calcium, magnesium, and sodium were generally higher during low flow than during high flow (table 13). Spatial trends from north to south in the study area were possibly related to geology - lower calcium and magnesium in Atwood Lake and Leesville Lake drainage basins (where the Monongahela Group bedrock is absent) than in the Piedmont Lake and Senecaville Lake drainage basins (which are partially underlain by the Monongahela Group) (fig. 5). The Monongahela Group contains proportionally more limestone - a rock composed chiefly of calcium carbonate and sometimes magnesium carbonate- than the other bedrock units in the area (Sedam and Francy, 1993).

Concentrations of all four major cations (calcium, magnesium, potassium, and sodium) were higher in mine-impacted sites than in non-mine-impacted sites (figs. $11 D, 11 I, 11 N$, $11 P$, and figs. 2-12 through 2-15). Elevated sodium concentrations were detected at sites with a component of brine relative to non-brine sites (fig. 12G), but no other major cations differed between the two groups.

\section{Nutrients}

Concentrations of ammonia met the aquatic life use criteria OMZM at all sites (table 14). No State aquatic life use criteria are established for other nutrients in Ohio streams, but development is in progress (OEPA, 2017b).

Nutrients are naturally present in soils but also can come from fertilizer, manure applied to fields, and sewage. Oilfield brines can contain elevated concentrations of ammonia (Blondes and others, 2017). Temporal and spatial trends in nutrient concentrations in the study area indicate that multiple processes, including source of water to streams (base flow versus runoff), in-lake uptake by aquatic vegetation, and reduction reactions occurring in lakes, could affect nutrient concentrations. At an individual site, higher-than-median concentrations of ammonia (fig. 2-31) and orthophosphate (fig. 2-33) tended to be associated with below-median flows, indicating a nonrunoff source. Greater-than-median concentrations of nitrate plus nitrite (fig. 2-32) tended to be associated with above-median flows, indicating a runoff source (table 13). Differences in nutrient concentrations among tributary streams and lake and below-dam sites indicated that some nutrient concentrations in and immediately downstream from lakes are affected by in-lake processes. Median concentrations of total dissolved nitrogen (fig. 2-36) and phosphorus (fig. 2-35) were similar at sites upstream from the lakes and gage sites below the dams (table 8), but median nitrate plus nitrite concentrations were higher in tributaries $(0.166 \mathrm{mg} / \mathrm{L})$ than in lakes $(<0.040 \mathrm{mg} / \mathrm{L})$ or downstream from dams ( $0.064 \mathrm{mg} / \mathrm{L}$ ) (table 8 and fig. 2-32), possibly indicating uptake by aquatic vegetation or organisms in the lakes. Median in-lake and tributary concentrations of nitrate plus nitrite were higher at Atwood and Tappan Lakes than at Piedmont and Senecaville Lakes (fig. 2-32). Like nitrate plus nitrite, median concentrations of orthophosphate were less in lakes $(<0.004 \mathrm{mg} / \mathrm{L})$ than in tributary streams $(0.007 \mathrm{mg} / \mathrm{L})$, 
possibly because of uptake by aquatic vegetation or organisms in the lakes (table 8).

Median concentrations of ammonia were higher at the gage sites downstream from the lakes (median of $0.08 \mathrm{mg} / \mathrm{L}$ ) than in the lakes (near-surface samples, median of $<0.01$ ) or upstream sites (median of 0.01) (table 8). The opposing nitrate and ammonia spatial trends likely were due to the conversion of nitrate to ammonia by redox reactions at depth within the lakes. Generally, manganese-reducing conditions occurred at below-dam sites in May and August 2015 and in May 2016 (dates varied slightly at Tappan and Senecaville sites) (table 15). According to the sequential order in which electron acceptors are used by microbes, manganese-reducing conditions indicate that nitrate has already been reduced to ammonia.

Particulate nitrogen includes living and dead algae, bacteria, and organism fragments (Illinois State Water Survey, 2017). Conforming with lakes having more biotic activity than the rapidly flowing streams, median concentrations of particulate nitrogen were higher in lakes $(0.21 \mathrm{mg} / \mathrm{L})$ and sites immediately downstream from the dams $(0.1765 \mathrm{mg} / \mathrm{L})$ than in tributary streams $(0.057 \mathrm{mg} / \mathrm{L})$ (table 8 and fig. 2-34).

\section{Metals and Trace Constituents}

Manganese concentrations in the four lake sites sampled (median of $2.325 \mu \mathrm{g} / \mathrm{L}$ ) were substantially less than at stream sites (median of $71.4 \mu \mathrm{g} / \mathrm{L}$ ) or gage sites below the dams (median of $73.7 \mu \mathrm{g} / \mathrm{L}$ ) (table 8 ), possibly because naturally occurring oxidation of manganese in the shallow sampling zones of the lakes (where plants are producing oxygen via photosynthesis) may cause manganese to precipitate out of water. Concentrations of manganese at the below-dam gage sites were highly variable with time (fig. 2-28), likely a result of lake-water releases. Sometimes the deep lake waters released from the dams were oxic and, at other times during the year, the deep lake waters were manganese reducing (table 15). Under manganese-reducing conditions, manganese that precipitated out of the shallow, oxic zone of the lake could redissolve upon reaching the deep zone of the lake and cause dissolved manganese concentrations below the dam to be elevated relative to the lake samples.

Considering tributary stream samples only (samples not affected by in-lake processes), the median manganese concentration at sites with a brine component $(140 \mu \mathrm{g} / \mathrm{L})$ was higher than at non-brine sites $(67.1 \mu \mathrm{g} / \mathrm{L})$ at a statistically significant level (fig. $12 F$ ). The median manganese concentration $(87.6 \mu \mathrm{g} / \mathrm{L})$ at mine-impacted sites was less than that of sites with a brine component but higher than that of other streams (fig. 11J). No aquatic life use criteria exist for manganese (table 14).

Iron concentrations were higher in the Atwood Lake and Leesville Lake drainage basins than in the Piedmont Lake and Senecaville Lake drainage basins (fig. 2-26), possibly resulting from geology in the contributing drainage basins (less Allegheny Group bedrock, more Monongahela Group bedrock from north to south in the study area). Iron concentrations were significantly less at mine-impacted sites (median of $5.7 \mu \mathrm{g} / \mathrm{L}$ ) than at non-mine-impacted sites (median of $52.2 \mu \mathrm{g} / \mathrm{L}$ ) (fig. $11 H$ ) and were higher at sites with a brine component (median of $54.8 \mu \mathrm{g} / \mathrm{L}$ ) than at non-brine sites (median of $31.7 \mu \mathrm{g} / \mathrm{L}$ ) (fig. 12D). However, based on the high variability of iron concentrations noted in QC replicate pairs, these apparent differences between groups - mine- and non-mine-impacted sites, brine component and non-brine sites - might be a result of laboratory variability rather than actual chemical differences between groups. No aquatic life use criteria exist for iron (table 14).

Median concentrations of iron were less at lake $(<4.0 \mathrm{mg} / \mathrm{L})$ and below-dam sites $(5.55 \mathrm{mg} / \mathrm{L})$ relative to stream sites $(36 \mathrm{mg} / \mathrm{L})$ (table 8$)$. This pattern possibly results from oxidation of iron (causing iron to precipitate out of water) in the shallow zone of the lake, where sampling occurred and where photosynthesis by aquatic vegetation produces oxygen. Iron-reducing conditions were observed in only 2 out of 36 below-dam samples (table 15), possibly indicating that once iron precipitated out of shallow lake waters it tended to stay in solid form, only redissolving into water in deep zones of the lakes under rare conditions (thus, iron concentrations remained relatively low at below-dam sites).

Even though the redox classification of 36 samples (table 15) downstream from dams indicated that iron-reducing conditions occurred only rarely and that no samples were consistent with sulfate-reducing conditions (in which sulfate is converted to sulfide, which can form hydrogen sulfide gas), the USACE periodically posted alerts regarding hydrogen sulfide gas below Atwood, Leesville, Tappan, Clendening, and Piedmont Lakes (USACE, 2016, 2017). Thus, sulfate-reducing conditions occur periodically. Although the samples downstream from dams are an indicator of lake bottom chemistry, the samples are aerated somewhat upon release from the dam and, thus, may underestimate the strength of reducing processes occurring at depth in the lakes during late spring and summer.

Aluminum was included in the analytical suite as a potential indicator of mine drainage. To eliminate systematic positive bias in environmental samples identified by QC samples, results for aluminum were censored at $20.8 \mu \mathrm{g} / \mathrm{L}$ for the purposes of this report- a concentration that is three times the average detectable blank concentration (see "Quality-Control Results" section). No statistically significant difference was noted between aluminum concentrations at mine-impacted and non-mine-impacted sites, suggesting that aluminum is a poor indicator of mine drainage in the study area. Aluminum concentrations were higher in samples collected in the Atwood Lake and Leesville Lake drainage basins than in samples collected in the Piedmont Lake and Senecaville Lake drainage basins, possibly because of geology. In all drainage basins, concentrations were higher in samples collected at abovemedian flows, suggesting a runoff source, rather than during below-median flows, possibly because of aluminum-rich clay particles washed into steams by rainfall. 
The trace elements arsenic, barium, boron, lithium, and strontium, in addition to bromide, were targeted for analysis because trace elements and bromide are present in oil-field brine. Barium is also a component of drilling mud. In the data collected for this study, the median concentrations of barium, bromide, and lithium were statistically higher in samples with a brine component than in non-brine samples (figs. $12 \mathrm{~A}$, $12 B$, and $12 E$, respectively). Mine drainage in the study area complicated the use of boron, lithium, and strontium as indicators of oil and gas influence on water quality, because median concentrations of these constituents were higher at a statistically significant level in samples collected at mine-impacted sites than in samples collected at non-mine-impacted sites (figs. $11 C, 11 K$, and $11 R$, respectively). Concentrations of arsenic, barium, boron, strontium, and zinc met the aquatic life use criteria at all sites (table 14).

\section{Volatile Organic Compounds}

The tables of VOC results (table 3-1) summarize detections of constituents for each sample at each site. If the result was less than the NWQL reporting level but higher than the NWQL detection limit, the result was designated with a lessthan symbol. An "E" denotes concentrations that were estimated by NWQL. For the purposes of this report, the reporting level for styrene was raised to $0.31 \mu \mathrm{g} / \mathrm{L}$ (see "Quality-Control Results" section). This higher reporting level was used in table 3-1.

In general, few VOC detections were higher than the NWQL reporting level. The only VOC detected in any of the 17 samples that contained a component of brine (designated by red text in table 3-1) was acetone, which was detected in 3 (18 percent) of these samples and in 11 percent of non-brine samples. The BTEX detections made up 24 of the 45 detections (53 percent) in the study area and are compounds that occur naturally in crude oil. The BTEX detections were not associated with sites containing a brine component. Considering that these VOC compounds are gasoline hydrocarbons and that most of the detections occurred during warmer months in and around the lakes (figs. 2-39 and 2-40), the detections were likely associated with increases in outdoor activities such as automobile and boating traffic.

Maximum VOC concentrations are listed in table 8. Aquatic life use criteria exist for several of these VOCs (table 14), but no VOC concentrations exceeded these criteria.

\section{Radium-226 and Radium-228}

Because of the ubiquitous nature of radium-226 and radium-228 in the environment, these radionuclides were detected in several field blanks, equipment blanks, and sourcesolution blanks. For the purposes of this report, the reporting levels for radium-226 and radium-228 were increased to 0.51 and $1.2 \mathrm{pCi} / \mathrm{L}$, respectively, to better identify sample concentrations that exceed background levels.
Radium-226 concentrations exceeded the reporting level in only two environmental samples-Brushy Fork near Tippecanoe, Ohio, on March 23, 2016 (0.51 $\pm 0.11 \mathrm{pCi} / \mathrm{L})$, which is in the Clendening Lake drainage basin, and Tappan Lake at Main Swimmers Beach, Ohio, on October 21, $2015(0.75 \pm 0.14 \mathrm{pCi} / \mathrm{L})$. Similarly, the radium-228 count of only one environmental sample exceeded the reporting level (Brushy Fork above Clendening Lake, Ohio, on October 27, $2015[1.2 \pm 0.2 \mathrm{pCi} / \mathrm{L}])$. Radionuclide counts did not exceed the aquatic life use criterion for combined radium-226 and radium-228 (5 pCi/L) (table 14$)$.

\section{Relation Between Water Chemistry and Drainage Basin Characteristics}

Flowback water or brines, or both, associated with oil and gas development contain elevated specific conductance and concentrations of total dissolved solids, calcium, magnesium, potassium, sodium, bicarbonate, chloride, sulfate, sulfide, iron, manganese, arsenic, barium, boron, bromide, lithium, strontium, total carbon, dissolved organic carbon, and selected VOCs as compared to streams (Gregory and others, 2011; Barbot and others, 2013; Engle and others, 2014). In addition, oil and gas development could be associated with sediment runoff into streams (from construction of access roads and well pads) - measured as turbidity and concentrations of suspended sediment - and concentrations of nutrients associated with those sediments (Entrekin and others, 2011). If streams were to be contaminated by flowback water or brines, or both, then concentrations of one or more of those same constituents might be increased in the stream water. Some of the constituents that are measured in higher concentrations in flowback water and brines also could be higher in the following examples:

- releases of brines and flowback water that could occur as spills on roads;

- oil-field brines spread on township roads for dust control that could wash into streams;

- salt spread on roads for deicing that could cause increases of specific conductance, total dissolved solids, sodium, and chloride in streams;

- wastewater treatment plant discharges to streams that could cause increases of specific conductance, total dissolved solids, sodium, chloride, total carbon, dissolved organic carbon, and nutrients;

- coal-mine drainage that could result in elevated concentrations of specific conductance, total dissolved solids, sulfate, iron, manganese, arsenic, total carbon, and dissolved organic carbon; and

- application of fertilizer to agricultural lands that could result in runoff to streams that is elevated in nutrients, potassium, chloride, and dissolved organic carbon. 


\section{Correlations}

Spearman's rank correlation coefficients were used to identify correlations between water chemistry and drainage basin characteristics that could affect water quality. Some of the constituents that were detected at increased concentrations in flowback water and brines also might be detected in increased concentrations in surface-mine runoff. To simplify interpretation of water-chemistry results, 11 sites with sulfatetype water that were likely impacted by lands associated with coal mining (mine-impacted sites) were identified and separated out for subsequent statistical analysis (table 11). All concentrations less than the common reporting level for a constituent were assigned the same value that was less than all reported concentrations, so that ranks of values less than the highest reporting level were tied, yet less than the rank for the lowest measured concentration. The Spearman's rank correlation coefficients require samples to be independent from one another. Spearman's rank correlation coefficients, then, were calculated for non-mine-impacted (table 16) and mine-impacted (table 17), non-nested stream sites separately using median water-chemistry values for each site and drainage basin characteristics that included (1) the density of producing conventional oil and gas wells, (2) the density of producing horizontal gas wells that were tapped into the Utica/Point Pleasant formation, (3) the density of wastewater treatment plants, (4) the percentage of lands associated with underground coal mines, (5) the percentage of lands associated with surface coal mines, (6) the density of road miles, (7) the percentage of township lands with permits to spread brine for dust control, (8) the percentage of land cover for agriculture, developed, and forest.

In the following discussion, only significant positive correlations (alpha 0.05 and higher) are mentioned. A positive correlation (highlighted green in tables 16-18) means that as the drainage basin characteristic increases (either in density or percentage), so does the median concentration or level of the constituent or property. The closer the value of Spearman's rank correlation coefficient to 1 (or negative 1), the stronger the correlation. Caution must be used when interpreting the correlations, because substantial correlations frequently were among the drainage basin characteristics themselves (table 18) - correlation does not equate to causation.

The following is a list of correlations between water chemistry and drainage basin characteristics for non-mineimpacted sites (table 16):

1. turbidity and suspended sediment results indicated strong positive correlations with the density of conventional oil and gas wells;
2. results indicated no significant correlations with the density of gas wells drilled into the Utica/Point Pleasant formation;

3. boron, orthophosphate, and phosphorus results indicated a strong positive correlation with the density of wastewater treatment plants;

4. $\mathrm{pH}$, total dissolved solids, potassium, sulfate, fluoride, ammonia, and particulate nitrogen results indicated moderate to strong positive correlations with the percentage of lands associated with surface coal mining;

5. silica and total dissolved nitrogen results indicated moderate to strong positive correlations with the density of road miles;

6. results indicated no significant correlations with the percentage of township lands with permits to spread brines; and

7. nitrate plus nitrite and total dissolved nitrogen results indicated moderate positive correlations with the percentage of agriculture land cover (as might be expected because of fertilizer application).

The following is a list of correlations between water chemistry and drainage basin characteristics for mineimpacted sites (table 17):

1. results indicated no significant positive correlations with the density of conventional oil and gas wells;

2. sulfide, silica, nitrate plus nitrite, and particulate nitrogen results indicated very strong positive correlations with the densities of gas wells drilled into the Utica/Point Pleasant formation;

3. turbidity, phosphorus, and total carbon results indicated very strong positive correlations with the density of wastewater treatment plants;

4. sodium, potassium, and strontium results indicated very strong positive correlations with the percentage of lands associated with surface coal mining;

5. results indicated no significant positive correlations with the density of road miles;

6. boron and orthophosphate results indicated strong positive correlations with the percentage of township lands with permits to spread brines; and

7. alkalinity, carbonate, and bicarbonate results indicated very strong positive correlations with the percentage of land cover for agriculture. 


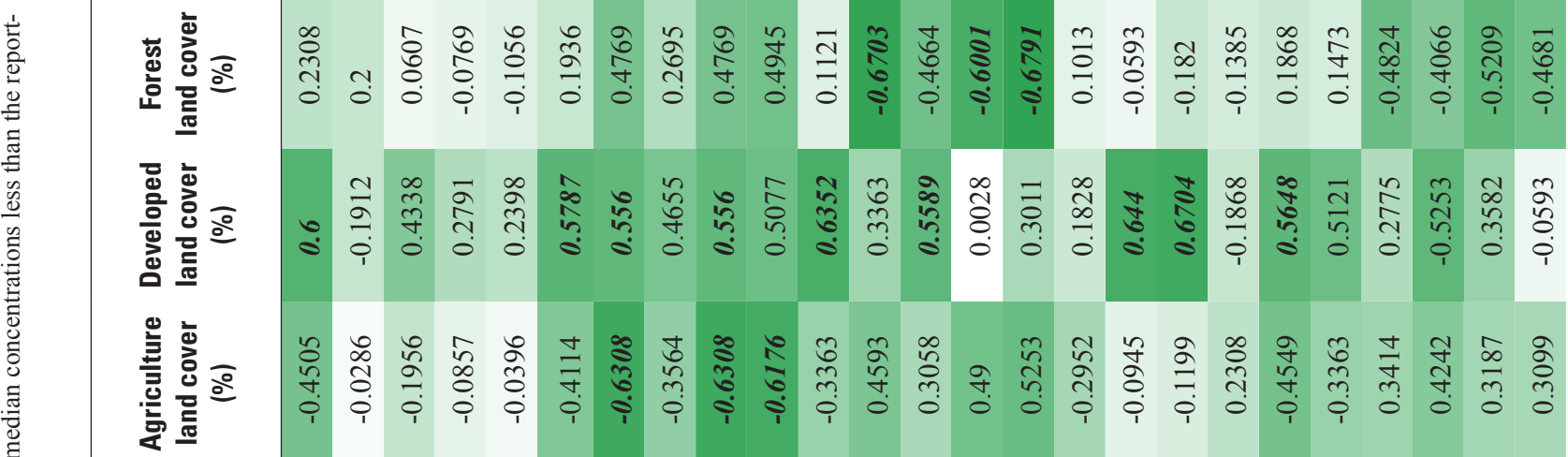

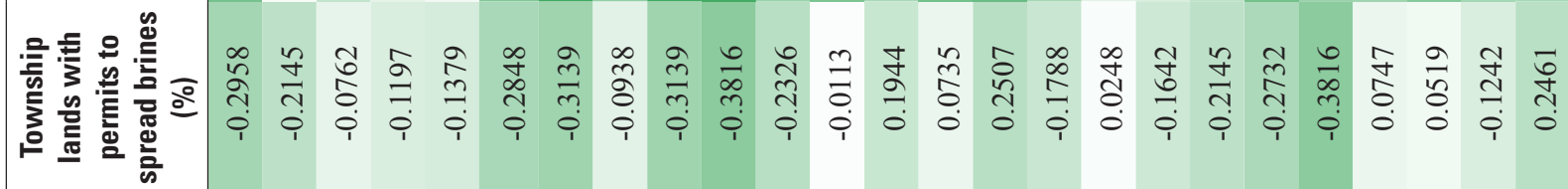

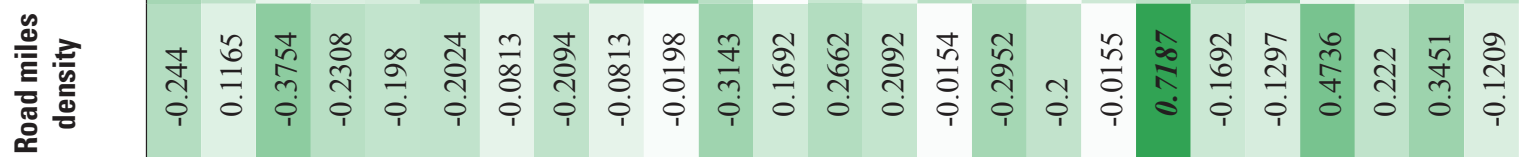

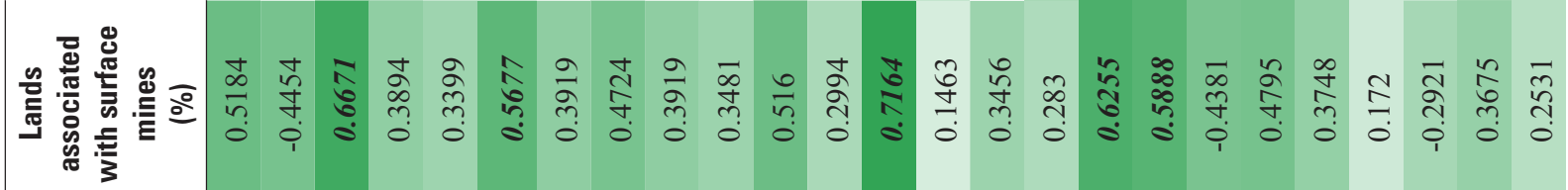

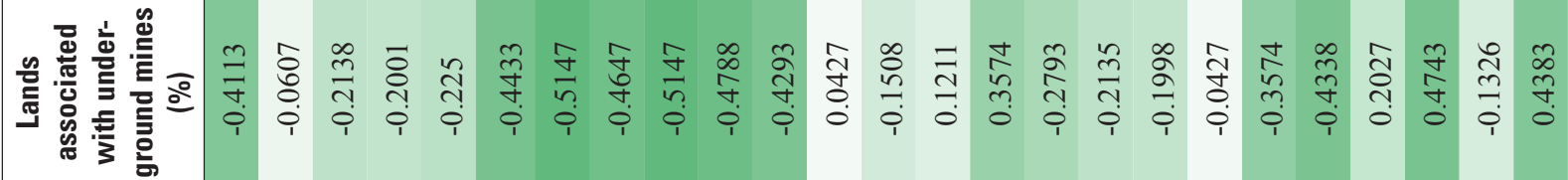

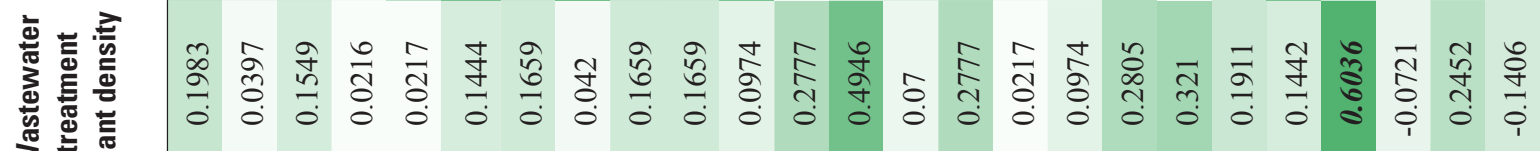
寻泀

茄

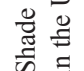

总

㐘南点产

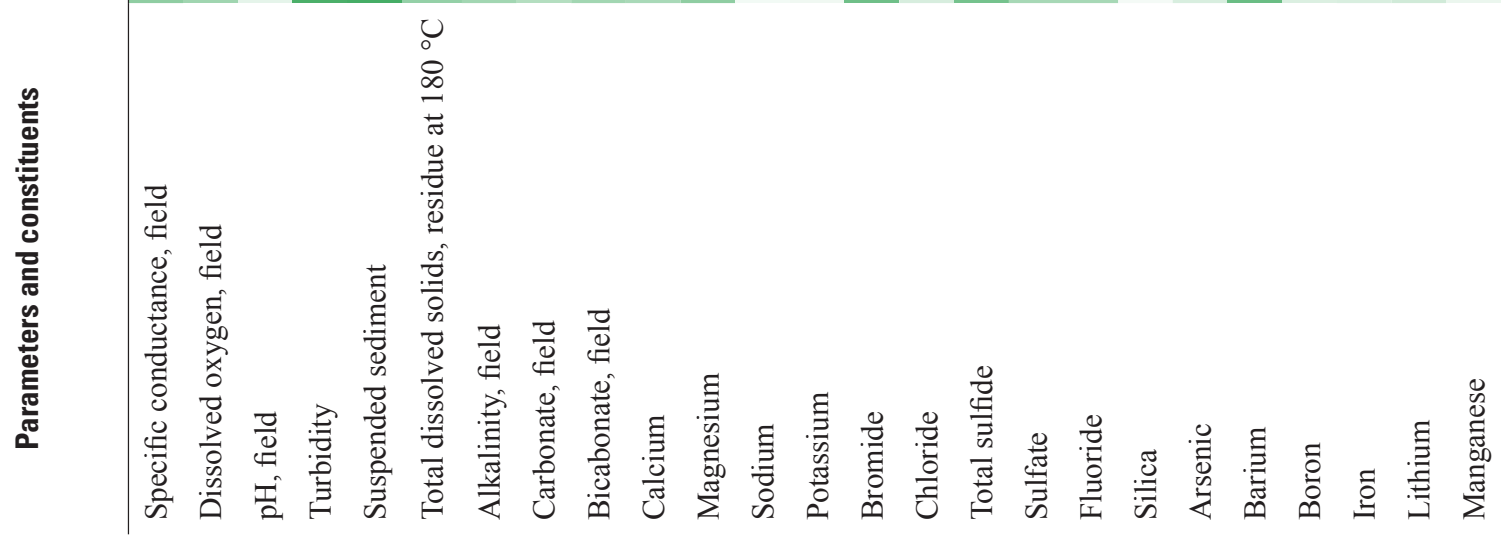




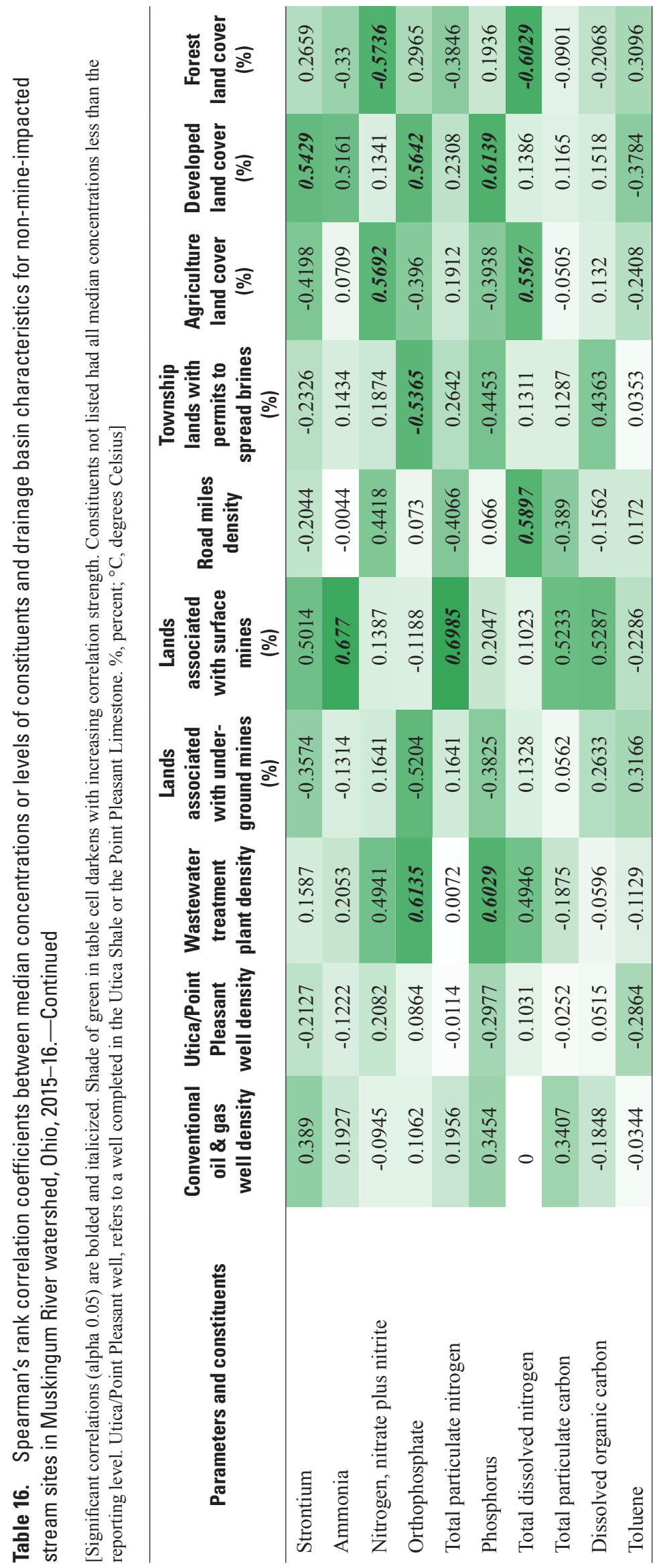




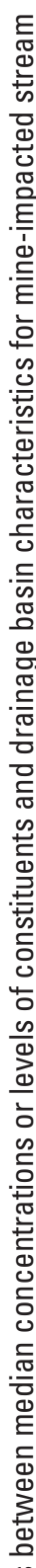

空

.

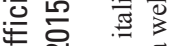

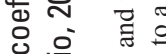

등 旁

형

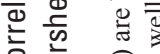

过 范

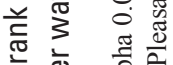

कs 离

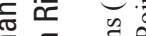

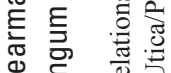

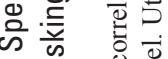

$\therefore \sum^{2} e_{0}^{0}$

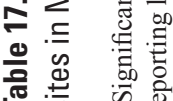

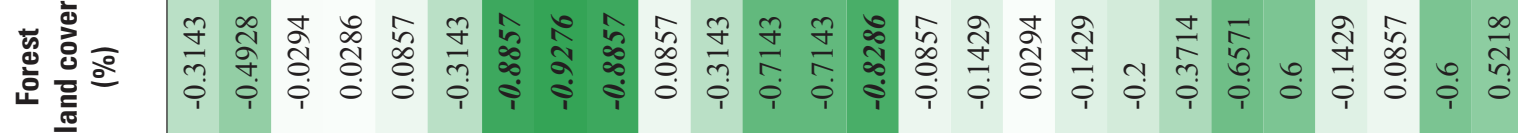

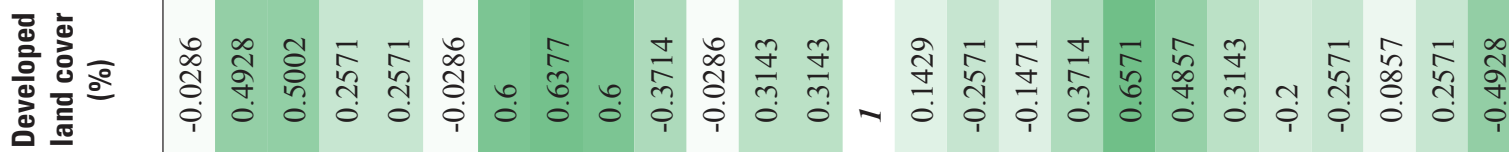

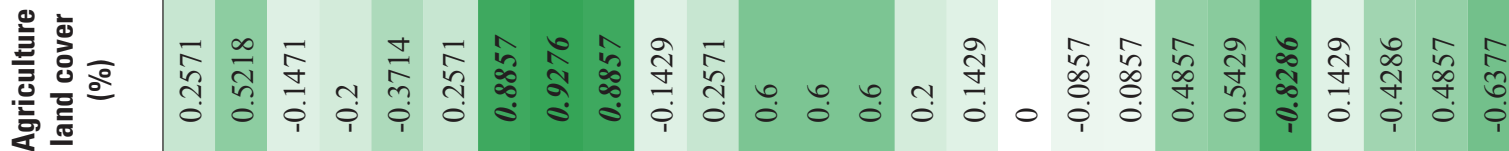

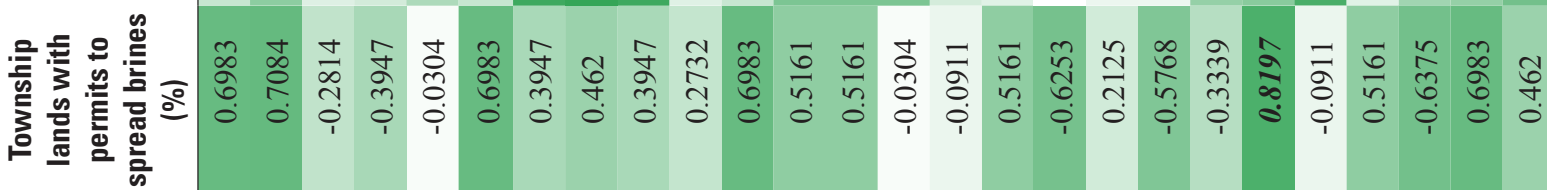

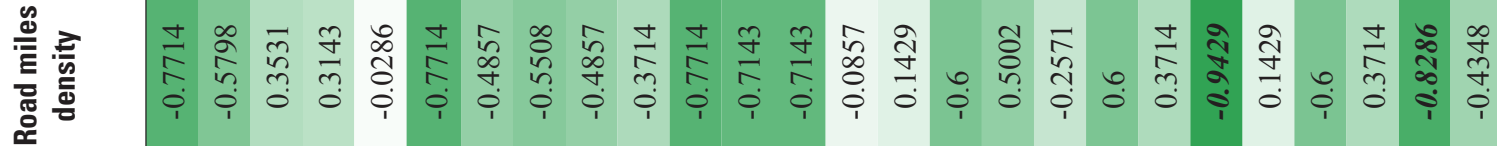

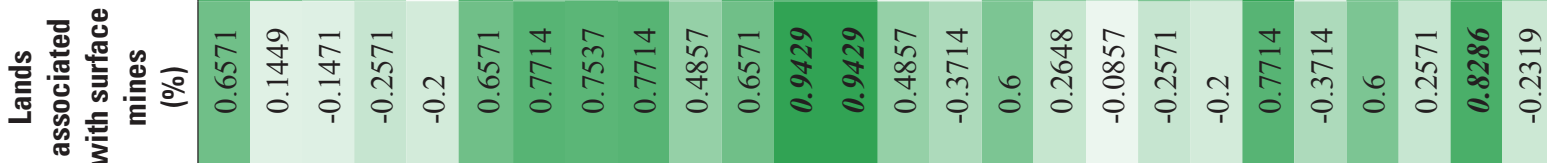

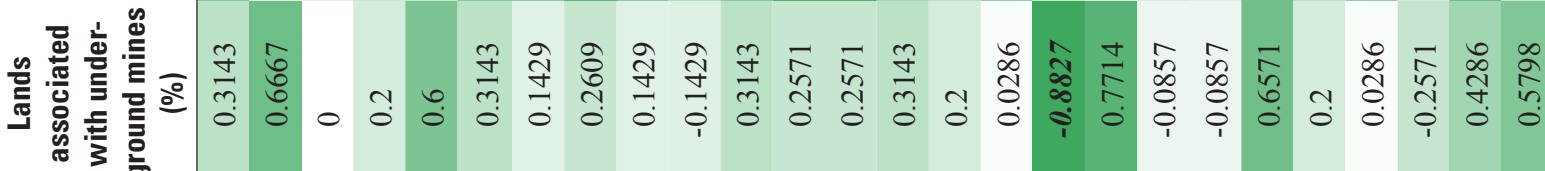

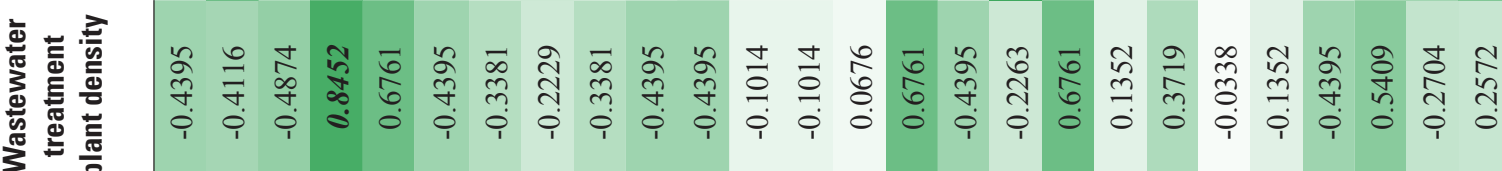

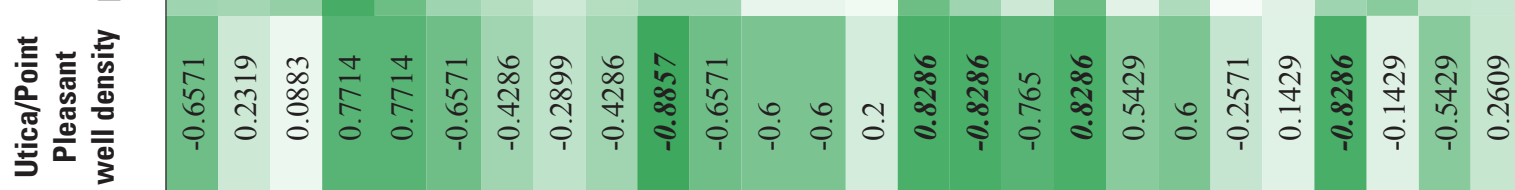

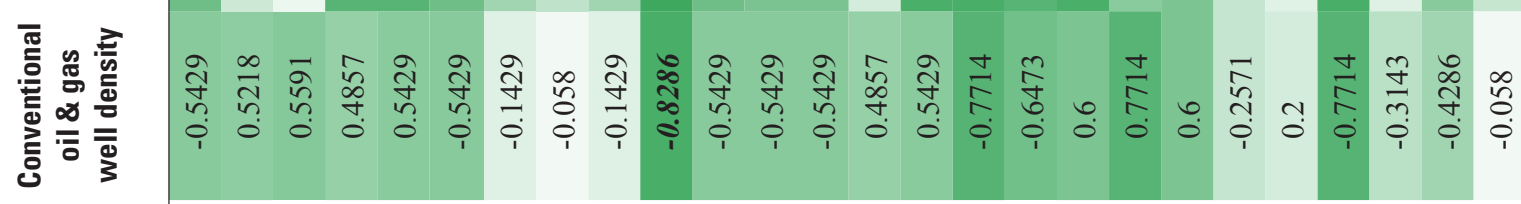

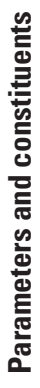

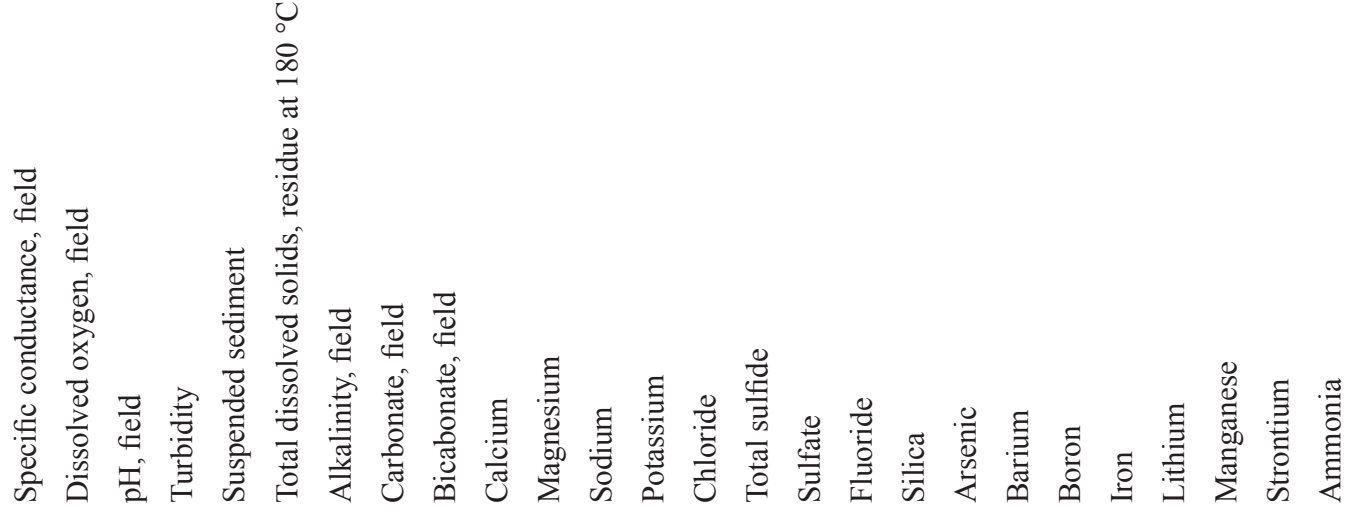




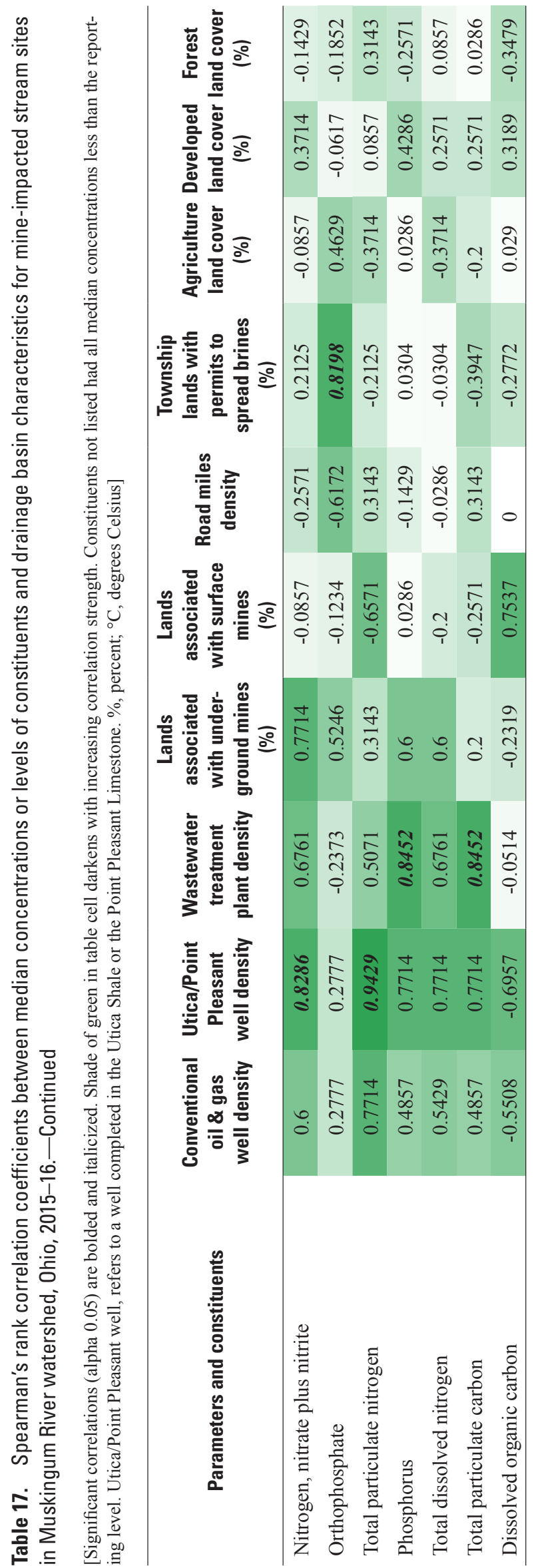




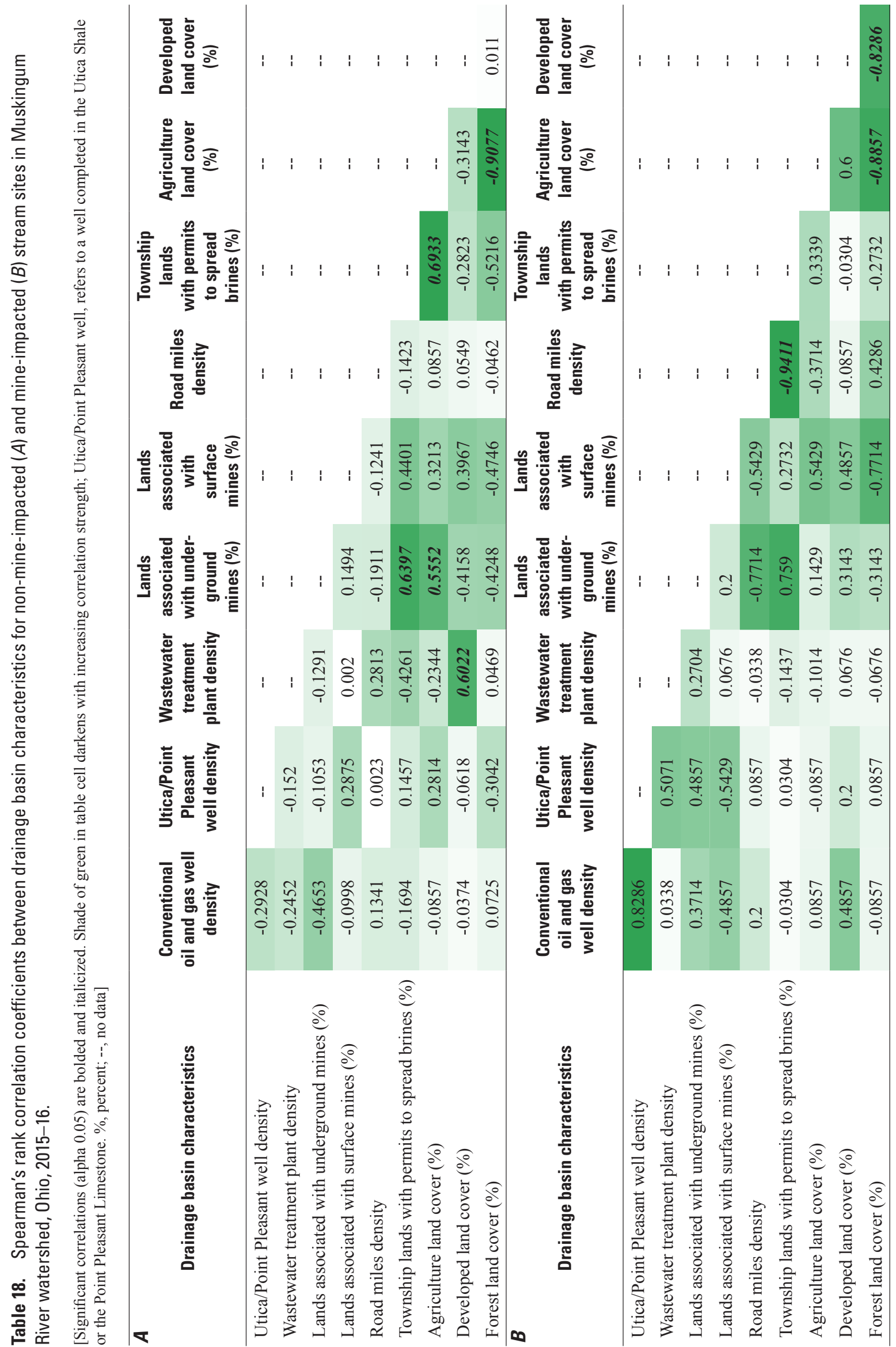




\section{Injection Wells}

During this study, only two active and two plugged waste injection wells were within the study area-three in the Atwood Lake drainage basin and one in the Piedmont Lake drainage basin (fig. 3). Some of the drainage basin areas that contained injection wells were upstream from and, thus, subbasins of other drainage basins. The nesting of drainages resulted in seven sites having at least one injection well in each of their drainage basins. For this analysis, seven median values were not enough to calculate meaningful Spearman's rank correlation coefficients. Instead, boxplots and the Wilcoxon rank-sum test were used to test differences among median constituent concentrations for sites with and without injection wells in their drainage areas. All concentrations less than the common reporting level for a constituent were assigned the same value that was less than all reported concentrations, so that ranks of values less than the highest reporting level were tied, yet less than the rank for the lowest measured concentration. The Wilcoxon rank-sum test requires samples to be independent from one another. To achieve this requirement, only non-nested stream sites were used. The number of samples with and without injection wells in their drainage areas was 16 and 101, respectively. In the following discussion, only significant differences (alpha 0.05) are mentioned.

Wilcoxon rank-sum test results indicated statistically significant differences between sites with and without injection wells in their drainage areas for the median concentrations of bromide, chloride, lithium, manganese, sodium, and total dissolved nitrogen concentrations (table 19). The boxplots for these constituents showed higher median concentrations at sites with injection wells in their drainage areas compared to sites without injection wells (figs. 14A-14F). Although bromide, chloride, lithium, and sodium are common oil- and

Table 19. Wilcoxon rank sum test Z-values and $p$-values between median concentrations of selected constituents at sites with and without injection wells in their drainage areas, Muskingum River watershed, Ohio, 2015-16.

[Categories were compared using the Wilcoxon rank sum test. Constituents that were different at a $p$-value of $<0.05$ are shown. Z-value, standard score or number of standard deviations an element is from the mean; $p$-value, statistical significance of a test result based on Z-value; $<$, less than]

\begin{tabular}{lcc}
\hline \multicolumn{1}{c}{ Constituent } & Z-value & $\boldsymbol{p}$-value \\
\hline Bromide & 5.80836 & $<0.0001$ \\
Chloride & 3.85547 & .0001 \\
Lithium & 2.52679 & .0115 \\
Manganese & 2.15777 & .0309 \\
Sodium & 2.53855 & .0111 \\
Total dissolved nitrogen & 2.26129 & .0237 \\
\hline
\end{tabular}

gas-related contaminants (Chambers and others, 2015; Cozzarelli and others, 2017), correlation does not equate to causation and data are lacking to ascertain whether the increased concentrations are related to oil and gas development or to the presence/absence of injection wells.

\section{Comparison of Current (2015-16) to Historical Chloride Concentrations}

Salinity is the total concentration of dissolved salts in water. Chloride, a major anion, is a major contributor to salinity in freshwater streams. Chloride concentrations in streams are influenced by the surrounding geology but also can be influenced by human activities such as oil and gas drilling, road deicing, and water treatment. As part of a baseline waterquality study, a temporal comparison of historical and current (2015-16) chloride concentrations can help in understanding potential impacts from human activities.

Chloride concentrations, like many chemical parameters of streams, typically vary as a function of flow. Chloride concentrations generally increase in streams during lower flow (when base flow is dominant) and decrease during higher flow (when runoff is dominant). In evaluating changes in chloride concentrations with time, only historical chloride concentrations with an associated streamflow measurement were used. Available historical chloride concentrations at Atwood (1965-75), Leesville (1965-89), Tappan (1965-91), Piedmont (1965-91), and Senecaville (1965-89) Lakes and streamflow data were placed into time-period categories (1960s, 1970s, 1980s), and the values were compared to current (2015-16) values measured at or near the sampling sites downstream from each lake dam. A comparison at Clendening Lake could not be made due to a lack of historical chloride and streamflow data pairs. Based on availability, either dissolved or total chloride concentrations and instantaneous or daily mean streamflow values were obtained online from the USACE (2018b) data dissemination tool and the USGS NWIS database (USGS, 2017a).

An analysis of covariance was done to test the effects of streamflow, time (decade), and the combined effects (cross product) of streamflow and time on chloride concentrations measured at the sampling sites downstream from Atwood, Leesville, Piedmont, Senecaville, and Tappan Lakes. Analyses indicated that streamflow was not significant in explaining the variation in chloride concentration. The tendency for chloride concentrations to vary little as a function of streamflow during a given decade is shown in figure 15 in a scatterplot of streamflow versus chloride concentrations from samples collected at or near McGuire Creek near Leesville, Ohio, downstream from the dam at Leesville Lake with regression lines fit to data collected during the 1960s, 1970s, 1980s, and 2015-16. In fact, the vertical positions of the regression lines suggest the likelihood of decadal shifts in concentration at this sampling site. 

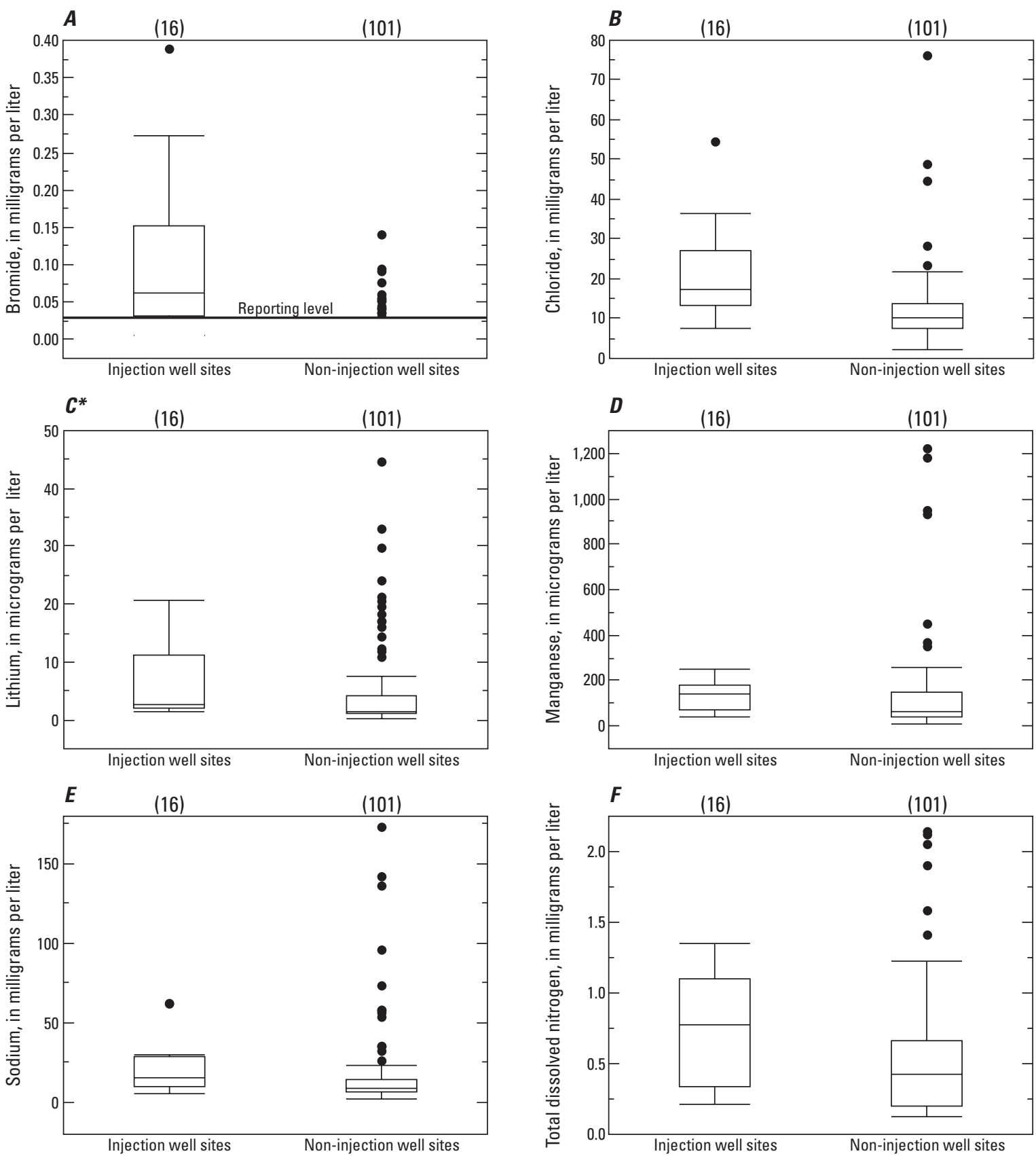

EXPLANATION

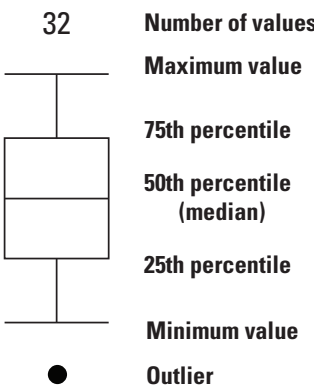

Figure 14. Constituent concentrations that differed at a statistically significant level ( $p$-value $<0.05)$ between sites with and without injection wells in their drainage areas (stream sites only), Muskingum River watershed, Ohio, 2015-16. $A$, bromide; $B$, chloride; $C$, lithium; $D$, manganese; $E$, sodium; and $F$, total dissolved nitrogen. 


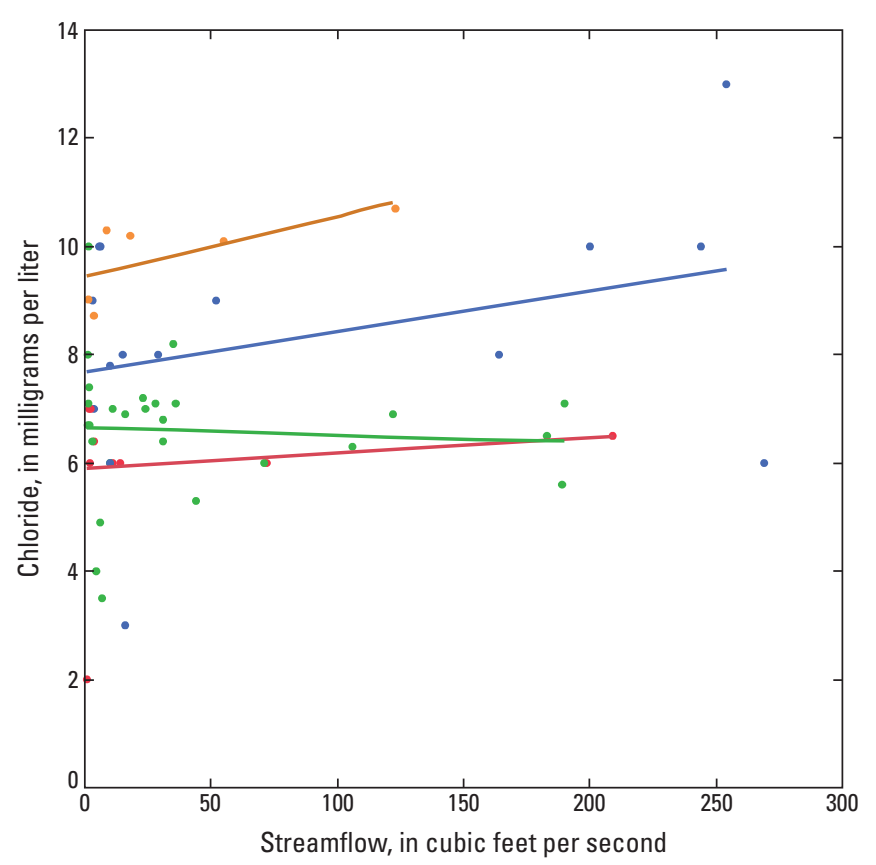

EXPLANATION

— Line of fit for decade [1960s]

— Line of fit for decade [1970s]

— Line of fit for decade [1980s]

— Line of fit for decade [2015-16]

Figure 15. Streamflow versus chloride concentrations with regression lines fit to data for each period (1960s, 1970s, 1980s, and 2015-16) at or near McGuire Creek near Leesville, Ohio, downstream from the dam at Leesville Lake.

The fact that chloride concentrations varied little with streamflow at the sites downstream from the dams was not unusual considering that streamflow in those locations is controlled by dam operations and, therefore, association between runoff-generating events and streamflow is less direct than in unregulated streams. In addition, runoff entering the lakes mixes with lake water before being discharged through the dam, which likely reduces the strong association between runoff and chloride concentration that is typical in streams not regulated by dams with permanent pools. Because chloride concentrations at the below-lake locations were not considerably influenced by streamflow, boxplots (fig. 16) could be used to examine the effects of time on chloride concentrations. Because of a gap in the data (1990-2015), a full assessment of trends in chloride concentrations could not be made.

For Atwood Lake, chloride concentrations seemed to increase from the 1960s to the 1970s (fig. 16). Data during the 1980s were not available. Chloride concentrations in samples collected for the study period (2015-16) were similar to chloride concentrations in samples collected in the 1970s. The absence of change in chloride concentrations since the 1970s for Atwood Lake was surprising, considering the brine component identified in 13 samples from the drainage basin (samples from Unnamed tributary near Dellroy, Ohio; Elliot Run near Dellroy, Ohio; and Willow Run near Dellroy, Ohio). However, further investigation indicated that most (58 percent) of the 299 conventional oil and gas and shale-gas wells in the drainage basin (fig. 3) were drilled in the 1970s. Only 27 oil and gas wells ( 9 percent of total wells) were added during 1980-2016 (Ohio Department of Natural Resources, Division of Oil \& Gas Resources, 2017a). Furthermore, use of the two plugged injection wells in the Atwood Lake drainage basin ceased in the early 1980s (Ohio Department of Natural Resources, Division of Oil \& Gas Resources, 2017c, well American Petroleum Institute numbers 34019204550000 and 34019202870000), although use of the active injection well in the drainage basin of Unnamed tributary near Dellroy, Ohio began in 2002 (Ohio Department of Natural Resources, Division of Oil \& Gas Resources, 2017c; well American Petroleum Institute number 34019203250000 ).

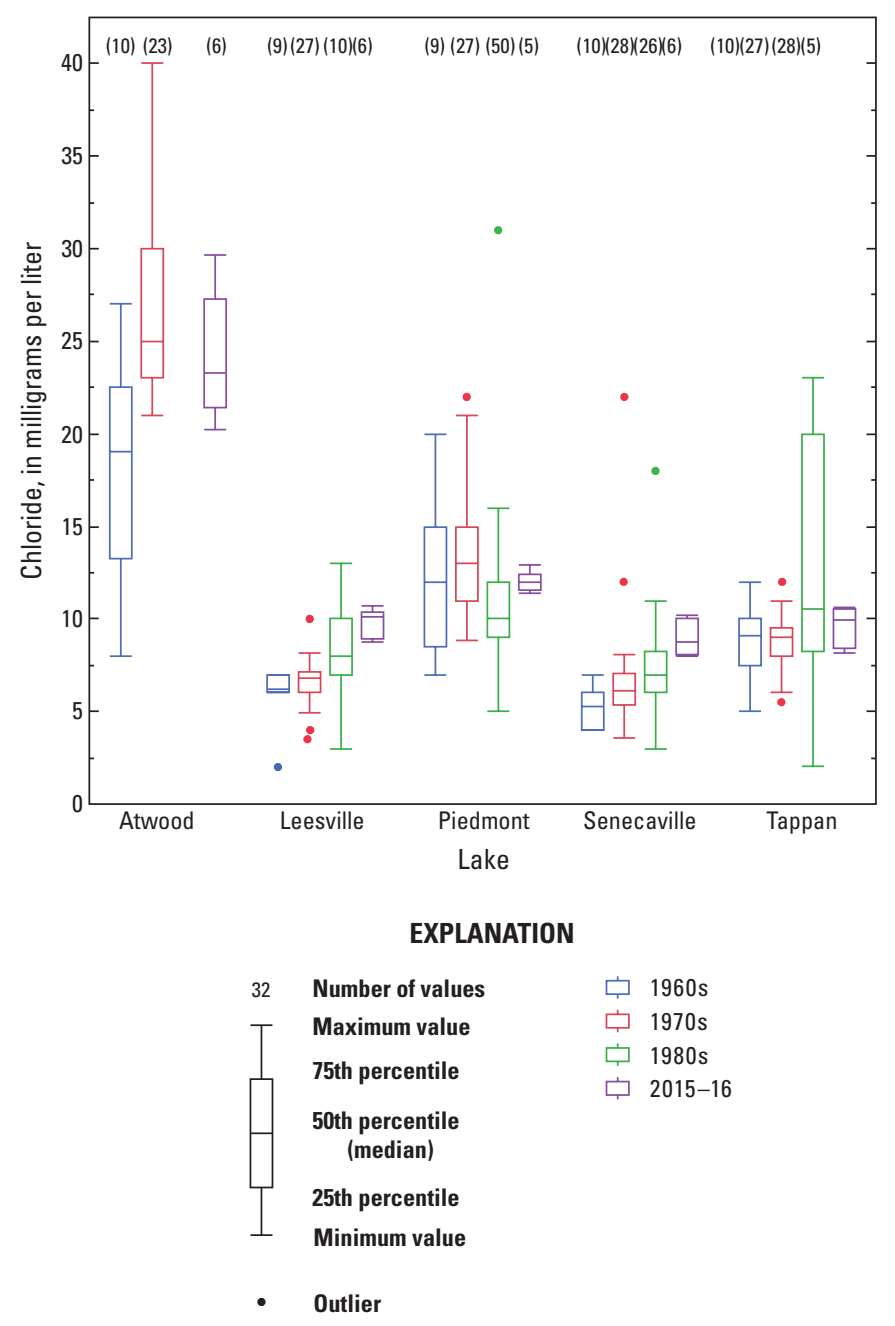

Figure 16. Chloride concentrations at Atwood, Leesville, Piedmont, Senecaville, and Tappan Lakes for each period (1960s, 1970s, 1980s, and 2015-16). 
For Leesville, Piedmont, and Senecaville Lakes, median chloride concentrations for the study period (2015-16) were higher than during the previous period (1980s) (fig. 16). Chloride concentrations for Piedmont Lake decreased in the 1980s but, since then, increased in the samples collected in 2015-16. $\mathrm{The} \mathrm{Cl}: \mathrm{Br}$ ratios indicated that the sources of chloride to recent samples (2015-16) from the Piedmont Lake drainage basin (depicted as purple circles in fig. 10A) were likely agricultural runoff or septic leachate (for samples plotting in the intermediate zone between road salt and brine mixing curves). For Leesville Lake, boxplots showed a progressive increase in chloride concentrations from the 1960s to 2015-16 (fig. 16). The $\mathrm{Cl}: \mathrm{Br}$ ratios indicated that the sources of chloride to samples from the Leesville Lake drainage basin (2015-16) were likely road salt (for samples plotting along the road salt mixing line in fig. $10 \mathrm{C}$ ), agricultural runoff, or septic leachate (for samples plotting in the intermediate zone between road salt and brine mixing curves). Similarly, at Senecaville Lake, the boxplots showed a progressive increase in chloride concentrations from the 1960 s to $2015-16$ (fig. 16). The source of chloride to recent samples (2015-16) from the Senecaville Lake drainage basin seems to be mixed, based on ratios of $\mathrm{Cl}$ :Br (fig. 10D) - two samples may contain a component of brine from the Berea Sandstone (plot below the Berea brine mixing line), two samples contain road salt (plot on the road salt mixing line), and several samples may have an agricultural runoff or septic leachate source (plot in the intermediate zone between road salt and brine mixing curves). Chloride concentrations for Tappan Lake increased in the 1980s but, since then, decreased for the samples collected in 2015-16. The source of chloride to recent samples (2015-16) from the Tappan Lake drainage (denoted by a gray triangle in fig. 10A) are mixed, based on ratios of $\mathrm{Cl}: \mathrm{Br}$ - one sample might contain a component of brine from the Berea Sandstone (plots below the Berea brine mixing line), one sample seems to contain road salt (plots on the road salt mixing line), but most samples are dilute water or have an agricultural runoff or septic leachate source (plot in the intermediate zone between road salt and brine mixing curves).

\section{Summary and Conclusions}

The U.S. Geological Survey (USGS), in cooperation with the Muskingum Watershed Conservancy District, led a study to assess baseline (2015-16) surface-water quality in six lake drainage basins within the Muskingum River watershed that are in the early years of shale-gas development. After steady production volumes for several years, crude oil production in Ohio increased more than 500 percent from 2012 to 2015, and natural gas production increased 11-fold - most of this increase can be attributed to an increase in shale-gas production. In 2015, 9 of the 10 most active counties in Ohio for oil and gas development were wholly or partially within the Muskingum River watershed. In addition to shale-gas development, the area has a history of conventional oil and gas development and coal mining.

At each of the 30 sampling sites (20 in tributaries flowing to the lakes, 4 in lakes themselves, and 6 downstream of the lakes), 6 samples were collected to characterize surface-water chemistry throughout a range of hydrologic conditions. The range of conditions that occurred at a site compared to the amount of variation captured by the sampling events was assessed at 14 USGS water-quality gages that were installed in the study area in 2015 . Water-quality sampling captured from 13.2 to 51.0 percent of the total variation in stream stage that occurred at the gage sites from April 1, 2015, through June 30, 2016, and 18.6 to 71.3 percent of total variation in specific conductance at the sites. The sampling events generally occurred during low flows (periods of higher groundwater contribution) rather than during runoff events (periods of high stream stage, decreased specific conductance), although a runoff event in March 2016 was captured at some sites. The 14 water-quality gages in the study area recorded a few sudden spikes in specific conductance that seem to represent "incidents"-releases of water with very different chemical characteristics relative to that usually detected in the stream. These incidents were not captured by the discrete waterquality sampling.

Trilinear diagrams of major ion chemistry revealed three main types of water in the study area-sulfate-dominated waters, bicarbonate-dominated waters, and waters with mixed bicarbonate and chloride anions. Most sites produced samples of bicarbonate-dominated water, and 11 sites with sulfate-type waters were designated as coal-mine-impacted sites based on sulfate-to-chloride ratios and criteria developed by the Ohio Department of Natural Resources, Division of Mineral Resources Management, for assessing mine drainage impacts in Ohio. Ohio brines coproduced with oil and gas and water known to be affected by nearby road salt sources are sodiumchloride-type waters - no stream samples were this water type, although mixed bicarbonate and chloride waters were detected in samples from Atwood Lake and Leesville Lake drainage basins.

The baseline assessment of surface-water quality in the study area indicated few water-chemistry constituents at concentrations that would adversely affect aquatic organisms. Chemical-specific aquatic life use criteria were not met in only three instances - two for total dissolved solids (at mineimpacted sites) and one for dissolved oxygen. Specifically, average total dissolved solids values at Standingstone Fork above Tappan Lake, Ohio, and Brushy Fork above Clendening Lake, Ohio (1,527.5 and 1,738 milligrams per liter [mg/L], respectively) exceeded the outside mixing zone average criterion $(1,500 \mathrm{mg} / \mathrm{L})$. Brushy Fork above Clendening Lake, Ohio, however, is designated as limited warmwater habitat and is exempted for total dissolved solids because of historical mining (OEPA, 2017a). The one-time dissolved oxygen value of $2.6 \mathrm{mg} / \mathrm{L}$ on August 12, 2015, at Brushy Fork near Tippecanoe, Ohio, was less than the outside mixing zone minimum of 
$4 \mathrm{mg} / \mathrm{L}$. This sample represents water released from near the bottom of Clendening Lake.

Mine drainage from historical coal mining in the region likely affected the quality of about one-third of the streams sampled. Concentrations or levels of bicarbonate, boron, calcium, carbonate, total dissolved solids, fluoride, magnesium, manganese, lithium, dissolved organic carbon, $\mathrm{pH}$, potassium, sodium, specific conductance, strontium, sulfate, and suspended sediment were statistically higher $($ alpha $=0.05)$ in mine-impacted sites than in non-mine-impacted sites. The elevated specific conductance, total dissolved solids, boron, lithium, and strontium concentrations detected at mineimpacted sites complicated the use of these constituents as indicators of oil and gas influence in the study area.

An accidental release of oil- and gas-related brines could increase salinity (sodium and chloride), the concentration of total dissolved solids in shallow groundwater and streams, and specific conductance. For this study, chloride concentrations in the study area ranged from 2.12 to $76.1 \mathrm{mg} / \mathrm{L}$. No samples had concentrations exceeding the recommended national criterion for aquatic life of $230 \mathrm{mg} / \mathrm{L}$ established by the U.S. Environmental Protection Agency - the concentration at which chloride is likely to harm freshwater plants and animals with long-term exposure.

Sources of chloride in water samples were evaluated using binary mixing curves and ratios of chloride-to-bromide. These ratios indicated that 13 samples from 3 sites (Unnamed tributary near Dellroy, Ohio; Elliot Run near Dellroy, Ohio; and Willow Run near Dellroy, Ohio) in the Atwood Lake drainage basin likely contained a component of brine, as well as four samples collected from other lake drainage basinsone from the Tappan Lake drainage basin, one from the Clendening Lake drainage basin, and two from Senecaville Lake drainage basin. For the three Atwood Lake drainage basin sites, a brine component was identified in multiple samples. These three drainage basins contained higher densities of conventional oil and gas wells (6.9 to 9.2 wells per square mile) relative to other drainage basins in the study area; and, of these three drainage basins, only the drainage basin of Willow Run near Dellroy, Ohio, contained a Utica/Point Pleasant formation shale-gas well. Binary mixing calculations indicated that the maximum percentage of brine mixed with dilute stream water in these samples was 0.03 to 0.1 percent by volume. Concentrations of barium, bromide, chloride, iron, lithium, manganese, and sodium were statistically higher (alpha $=0.05)$ in samples with a component of brine than in samples without a component of brine.

The only volatile organic compound detected at any of the 17 samples that had a brine component was acetone, detected in 3 (18 percent) of these samples and in 11 percent of non-brine samples. Benzene, toluene, ethylbenzene, and xylene (BTEX) made up 24 of the 45 detections (53 percent) in the study area and are compounds that occur naturally in crude oil. The BTEX detections were not associated with sites with a brine component. Considering that these volatile organic compounds are gasoline hydrocarbons and that most of the detections occurred during warmer months in and around the lakes, the detections likely are associated with increases in outdoor activities such as automobile and boating traffic.

Because of the ubiquitous nature of radium-226 and radium-228 in the environment, these radionuclides were detected in several field blanks, equipment blanks, and source-solution blanks and, as such, the reporting levels were increased to identify samples with counts higher than natural background levels. Radium-226 counts in only two environmental samples exceeded background levelsBrushy Fork near Tippecanoe, Ohio, on March 23, 2016 $(0.51 \pm 0.11 \mathrm{pCi} / \mathrm{L})$, and Tappan Lake at Main Swimmers Beach, Ohio, on October 21, 2015 (0.75 \pm 0.14 pCi/L). Similarly, radium-228 was detected in only one environmental sample (Brushy Fork above Clendening Lake, Ohio, on October 27, $2015[1.2 \pm 0.2 \mathrm{pCi} / \mathrm{L}])$ at a concentration higher than background levels.

A brine signature, potentially indicative of oil and gas contamination, was identified at three sites (Unnamed tributary near Dellroy, Ohio; Elliot Run near Dellroy, Ohio; and Willow Run near Dellroy, Ohio) in the Atwood Lake drainage basin. Unnamed tributary near Dellroy, Ohio, and Elliot Run near Dellroy, Ohio, contained active or plugged waste injection wells, or both. Results from the study indicated significant differences in the median concentrations of bromide, chloride, lithium, manganese, sodium, and total dissolved nitrogen among sites with and without injection wells in their drainage areas. Bromide, chloride, lithium, and sodium, which are common oil- and gas-related contaminants, indicated higher median concentrations at sites with injection wells in their drainage areas compared to sites without injection wells.

Historical streamflow data and chloride concentrations from the 1960s, 1970s, and 1980s at Atwood (1965-75), Leesville (1965-89), Tappan (1965-91), Piedmont (1965-91), and Senecaville (1965-89) Lakes were compared to current (2015-16) values at or near the sampling sites downstream from each lake dam. An analysis of covariance was done to test the effects of streamflow, time (decade), and the combined effects (cross product) of streamflow and time on chloride concentrations. Those analyses indicated that streamflow was not significant in explaining the variation in chloride concentration, likely because flows at these sites are controlled by dam operations; therefore, association between runoff-generating events and streamflow is less direct than in unregulated streams. Instead, boxplots of chloride concentration grouped by decade were used to evaluate changes in chloride concentrations with time. Median chloride concentrations for Tappan Lake seemed to decrease from the 1980 s to $2015-16$. From the 1980s to the study period (2015-16), chloride concentrations increased in three lakes - Leesville, Piedmont, and Senecaville Lakes. Chlorideto-bromide ratios indicated that sources of chloride in these drainage basins were mixed and likely included road salt, agricultural runoff, septic leachate, and (in a few instances) possible brine from oil and gas drilling. For Atwood Lake, 
chloride concentrations increased from the 1960s to the 1970s, but concentrations in the samples collected in the 1970s and 2015-16 were similar. The lack of change in chloride concentrations since the 1970 s was surprising, considering the brine component that was identified in 13 samples from the drainage basin (samples from Unnamed tributary near Dellroy, Ohio; Elliot Run near Dellroy, Ohio; and Willow Run near Dellroy, Ohio). However, the lack of change in chloride is consistent with the history of oil and gas development in the drainage basin, considering that only 27 oil and gas wells (9 percent of total conventional and shale-gas wells in the drainage basin) were added during 1980-2016 and that use of the two plugged injection wells in the Atwood Lake drainage basin ceased in the early 1980s.

\section{References Cited}

Abate, C., 1993, A numerical modeling approach to estimation of parameters describing groundwater flow in coal-bearing rocks of the Allegheny Plateau: University Park, Pennsylvania State University, Ph.D. dissertation, 73 p.

American Public Health Association, 1998, Standard methods for the examination of water and wastewater (20th edition): Washington, D.C., American Water Works Association, and Water Environment Federation, p. 3-37 to 3-43.

ASTM International, 2013, Standard test methods for determining sediment concentration in water samples: West Conshohocken, Pa., accessed February 23, 2018, at https://www.astm.org/Standards/D3977.htm.

Barbot, E., Vidic, N.S., Gregory, K.B., and Vidic, R.D., 2013, Spatial and temporal correlation of water quality parameters of produced waters from Devonian-Age shale following hydraulic fracturing: Environmental Science \& Technology, v. 47 , no. 6 , p. $2562-2569$.

Blondes, M.S., Gans, K.D., M.E., Engle, M.A., Kharaka, Y.K., Reidy, M.E., Saraswathula, V., Thordsen, J.J., Rowan, E.L., and Morrissey, E.A., 2017, National produced waters geochemical database, v2.3 (provisional): U.S. Geological Survey, Energy Resources Program, available at https://energy.usgs.gov/EnvironmentalAspects/ EnvironmentalAspectsofEnergyProductionandUse/ ProducedWaters.aspx\#3822349-data.

Bloyd, R.W., Jr., 1974, Summary appraisals of the Nation's ground-water resources - Ohio region: U.S. Geological Survey Professional Paper 813-A, 41 p.

Brenton, R.W., and Arnett, T.L., 1993, Methods of analysis by the U.S. Geological Survey National Water Quality Laboratory-Determination of dissolved organic carbon by UVpromoted persulfate oxidation and infrared spectrometry: U.S. Geological Survey Open-File Report 92-480, 12 p.
Chambers, D.B., Kozar, M.D., Messinger, Terence, Mulder, M.L., Pelak, A.J., and White, J.S., 2015, Water quality of groundwater and stream base flow in the Marcellus Shale Gas Field of the Monongahela River Basin, West Virginia, 2011-12 (ver. 1.1, June 25, 2015): U.S. Geological Survey Scientific Investigations Report 2014-5233, 75 p., https://dx.doi.org/10.3133/sir20145233.

Connor, B.F., Rose, D.L., Noriega, M.C., Murtagh, L.K., and Abney, S.R., 1998, Methods of analysis by the U.S. Geological Survey National Water Quality Laboratory-Determination of 86 volatile organic compounds in water by gas chromatography/mass spectrometry, including detections less than reporting limits: U.S. Geological Survey OpenFile Report 97-829, 78 p.

Covert, S. Alex., Jagucki, Martha, and Huitger, Carrie, 2018, Data from quality-control equipment blanks, field blanks, and field replicates for baseline water quality of an area undergoing shale-gas development in the Muskingum River watershed, Ohio, 2015-16: U.S. Geological Survey data release, https://doi.org/10.5066/F7GF0SRT.

Cozzarelli, I.M., Skalak, K.J., Kent, D.B., Engle, M.A., Benthem, A., Mumford, A.C., Haase, K., Farag, A., Harper, D., Nagel, S.C., Iwanowicz, L.R., Orem, W.H., Akob, D.M., Jaeschke, J.B., Galloway, J., Kohler, M., Stoliker, D.L., and Jolly, G.D., 2017, Environmental signatures and effects of an oil and gas wastewater spill in the Williston Basin, North Dakota: Science of the Total Environment, v. 579, p. 1781-1793, accessed February 22, 2018, at https://www.sciencedirect.com/science/article/pii/ S0048969716326201?via\%3Dihub.

Davis, S.N., Whittemore, D.O., and Fabryka-Martin, J., 1998, Uses of chloride/bromide ratios in studies of potable water: Ground Water, v. 36, no. 2, p. 338-350.

Electronic Code of Federal Regulations, 2018a, Title 40Protection of the environment, Part 434-Coal mining point source category BPT, BAT, BCT limitations and new source performance standards: accessed April 12, 2018, at https://ecfr.io/Title-40/pt40.32.434.

Electronic Code of Federal Regulations, 2018b, Title 40-Protection of the environment, Part 136 - Guidelines establishing test procedures for the analysis of pollutants: accessed April 12, 2018, at https://ecfr.io/Title-40/pt40.32.136.

Engelke, M.J., Jr., Roth, D.K., and others, 1981, Hydrology of Area 7, Eastern Coal Province, Ohio: U.S. Geological Survey Open-File Report 81-815, 60 p.

Engle, M.A., Cozzarelli, I.M., and Smith, B.D., 2014, USGS investigations of water produced during hydrocarbon reservoir development. U.S. Geological Survey Fact Sheet 2014-3104, 4 p. 
Entrekin, S., Evans-White, M., Johnson, B., and Hagenbuch, E., 2011, Rapid expansion of natural gas development poses a threat to surface waters: Frontiers in Ecology and the Environment, v. 9, p. 503-511.

Esri, 2017, ArcMap_Release 10.1 [Computer software]: Redlands, CA, Environmental Systems Research Institute.

Fenneman, N.M., and Johnson, D.W., 1946, Physiographic divisions of the coterminous U.S.: U.S. Geological Survey special map series, scale 1:7,000,000.

Ferrell, G.M., 1988, West Virginia ground-water quality, in Moody, D.W., Carr, J.E., Chase, E.B., and Paulson, R.W., comps., National Water Summary 1986-Hydrologic events and ground-water quality: U.S. Geological Survey WaterSupply Paper 2325, p. 523-530.

Feth, J.H., 1981, Chloride in natural continental water-A review: U.S. Geological Survey Water-Supply Paper 2176, $30 \mathrm{p}$.

Fishman, M.J., ed., 1993, v. 93-125. Methods of analysis by the U.S. Geological Survey National Water Quality Laboratory-Determination of inorganic and organic constituents in water and fluvial sediments, U.S. Geological Survey Open-File Report 93-125, 217 p.

Fishman, M.J., and Friedman, L.C., eds., 1989, Methods for determination of inorganic substances in water and fluvial sediments (3d edition): U.S. Geological Survey Techniques of Water-Resources Investigations, book 5, chap. A1, 545 p.

Francy, D.S., and Shaffer, K.H., 2008, Quality-assurance plan for water-quality activities in the USGS Ohio Water Science Center: U.S. Geological Survey Open-File Report 2008-1250, 73 p.

Garbarino, J.R., Kanagy, L.K., and Cree, M.E., 2005, Determination of elements in natural-water, biota, sediment, and soil samples using collision/reaction cell inductively coupled plasma-mass spectrometry: U.S. Geological Survey Techniques and Methods, book 5, chap. B1, 88 p.

Gregory, K.B., Vidic, R.D., and Dzombak, D.A., 2011, Water management challenges associated with the production of shale gas by hydraulic fracturing: Elements, v 7, no. 3, p. 181-186.

Guerra, K., Dahm, K., and Dundorf, S., 2011, Oil and gas produced water management and beneficial use in the Western United States: U.S. Department of the Interior, Bureau of Reclamation, Science and Technology Program Report No. 157,113 p.

Hach Company, 1989, Water analysis handbook: Loveland, Colo., 690 p.
Haefner, R.J., and Simonson, L.A., 2010, Summary of hydrologic data for the Tuscarawas River Basin, Ohio, with an annotated bibliography: U.S. Geological Survey Scientific Investigations Report 2010-5010, 115 p.

Harlow, G.E., Jr., and LeCain, G.D., 1993, Hydraulic characteristics of, and ground water flow in, coal bearing rocks of Southwestern Virginia: U.S. Geological Survey WaterSupply Paper 2388, 36 p.

Helsel, D.R., 1983, Mine drainage and rock type influences on eastern Ohio stream water quality: Water Resources Bulletin, v. 19 , no. 6 , p. 881-887.

Helsel, D.R., and Hirsch, R.M., 2002, Statistical methods in water resources: U.S. Geological Survey Techniques of Water-Resources Investigations, book 4, chap. A3, 522 p.

Hem, J.D., 1985, Study and interpretation of the chemical characteristics of natural water: U.S. Geological Survey Water-Supply Paper 2254, 263 p.

Homer, C.G., Dewitz, J.A., Yang, L., Jin, S., Danielson, P., Xian, G., Coulston, J., Herold, N.D., Wickham, J.D., and Megown, K., 2015, Completion of the 2011 National Land Cover Database for the conterminous United StatesRepresenting a decade of land cover change information: Photogrammetric Engineering and Remote Sensing, v. 81, no. 5, p. 345-354.

Illinois State Water Survey, 2017, Nitrogen cycles project: accessed September 7, 2017, at http://www.isws.uiuc.edu/ nitro/nspecies.asp.

Jones, A.L., 1988, Geologic setting and water quality of selected basins in the active coal-mining areas of Ohio, June 1985 through December 1986: U.S. Geological Survey Water-Resources Investigations Report 88-4084, 85 p., 4 pls.

Jones, A.L., and Sroka, B.N., 1997, Effects of highway deicing chemicals on shallow unconsolidated aquifers in Ohio, interim report, 1988-93: U.S. Geological Survey WaterResources Investigations Report 97-4027, 139 p.

Jurgens, B.C., McMahon, P.B., Chapelle, F.H., and Eberts, S.M., 2009, An Excel workbook for identifying redox processes in groundwater: U.S. Geological Survey Open-File Report 2009-1004, 8 p.

Knuth, M., Jackson, J.L., and Whittemore, D.O., 1990, An integrated approach to identifying the salinity source contaminating a ground-water supply: Ground Water, v. 28, no. 2, p. 207-214.

Koltun, G.F., Kula, S.P., and Puskas, B.M., 2006, A streamflow statistics (StreamStats) Web application for Ohio: U.S. Geological Survey Scientific Investigations Report 2006-5312, 62 p. 
Krieger, H.L., 1980, Prescribed procedures for measurement of radioactivity in drinking water: U.S. Environmental Protection Agency, Environmental Monitoring and Support Laboratory, accessed April 12, 2018, at http://synectics.net/public/library/StreamResource. axd?DSN=pub\&Mode=FileImage_Inline \&ID=2310.

LAWriter Ohio Laws and Rules, 2017a, Ohio Administrative Code 3745-1-24-Muskingum River drainage basin: accessed May 31, 2017, at http://codes.ohio.gov/ oac/3745-1-24v1.

LAWriter Ohio Laws and Rules, 2017b, Ohio Administrative Code 3745-1-35-Aquatic life and wildlife criteria: accessed May 31, 2017, at http://codes.ohio.gov/ oac/3745-1-35v1.

Martin, J.D., 2001, Variability of pesticide detections and concentrations in field replicate water samples collected for the National Water-Quality Assessment Program, 1992-97: U.S. Geological Survey Water-Resources Investigations Report 01-4178.

McCoy, K.J., Yager, R.M., Nelms, D.L., Ladd, D.E., Monti, Jack, Jr., and Kozar, M.D., 2015, Hydrologic budget and conditions of Permian, Pennsylvanian, and Mississippian aquifers in the Appalachian Plateaus Physiographic Province: U.S. Geological Survey Scientific Investigations Report 2015-5106, 77 p., accessed February 23, 2018, at https://pubs.er.usgs.gov/publication/sir20155106.

McCurdy, D.E., Garbarino, J.R., and Mullin, A.H., 2008, Interpreting and reporting radiological water-quality data: U.S. Geological Survey Techniques and Methods, book 5, chap. B6, 33 p.

Midwestern Regional Climate Center, 2017, Midwest Climate: Climate Summaries: accessed April 12, 2018, at http://mrcc.isws.illinois.edu/mw_climate/ climateSummaries/climSumm.jsp.

Mueller, D.K., Schertz, T.L., Martin, J.D., and Sandstrom, M.W., 2015, Design, analysis, and interpretation of field quality-control data for water-sampling projects: U.S. Geological Survey Techniques and Methods, book 4, chap. C4, 54 p., https://dx.doi.org/10.3133/tm4C4.

Muskingum Watershed Conservancy District (MWCD), 2016, 2016 annual report of operations, 148 p.: accessed June 20, 2017, at https://www.mwcd.org/ upload/2016_annual_report_of_operations.pdf.

Muskingum Watershed Conservancy District (MWCD), 2017a, What is the MWCD?: Muskingum Watershed Conservancy District web page, accessed May 17, 2017, at https://www.mwcd.org/get-to-know-us/what-is-the-mwcd.
Muskingum Watershed Conservancy District (MWCD), 2017b, Enjoy our lakes: Muskingum Watershed Conservancy District web page, accessed May 17, 2017, at https://www.mwcd.org/enjoy-our-lakes.

Ohio Department of Natural Resources, Division of Geological Survey, 2004, Oil and gas fields map of Ohio: Ohio Department of Natural Resources, Division of Geological Survey Map PG-1, generalized page-size version with text, 2 p., scale 1:2,000,000. (Updated 2014.)

Ohio Department of Natural Resources, Division of Mineral Resources Management, (ODNR-DMRM), 2016, Mine drainage impact assessment of Ohio watersheds: Ohio Department of Natural Resources, accessed May 18, 2017, at http://minerals.ohiodnr.gov/Portals/minerals/pdf/amd/ Mine-Drainage-Impact-Assessment.pdf.

Ohio Department of Natural Resources, Division of Mineral Resources Management, (ODNR-DMRM), 2017, Mines of Ohio: Ohio Department of Natural Resources, Division of Mineral Resources Management web page, accessed April 12, 2018, at https://gis.ohiodnr.gov/ MapViewer/?config=OhioMines.

Ohio Department of Natural Resources (ODNR), Division of Oil \& Gas Resources, 2013, 2012 Ohio oil and gas summary: accessed April 12, 2018, at http://oilandgas.ohiodnr. gov/portals/oilgas/pdf/O\&GAnnRep_2012_FIN.pdf.

Ohio Department of Natural Resources (ODNR), Division of Oil \& Gas Resources, 2015, 2014 Ohio oil \& gas summary, accessed April 12, 2018, at http://oilandgas.ohiodnr.gov/ portals/oilgas/pdf/oilgas14.pdf.

Ohio Department of Natural Resources (ODNR), Division of Oil \& Gas Resources, 2017a, Ohio oil \& gas well database, accessed April 12, 2018, at http://oilandgas.ohiodnr.gov/ well-information/oil-gas-well-database.

Ohio Department of Natural Resources (ODNR), Division of Oil \& Gas Resources, 2017b, 2015 production report: accessed April 12, 2018, at http://oilandgas.ohiodnr.gov/portals/oilgas/spreadsheets/production/horizontal/2015/2015 Horizontal\%20Shale\%20Production_Annual_for_website_ as\%20of\%205-17-17.xlsx.

Ohio Department of Natural Resources (ODNR), Division of Oil \& Gas Resources, 2017c, Ohio oil \& gas well locator: accessed April 12, 2018, at http://oilandgas.ohiodnr.gov/ well-information/oil-gas-well-locator. 
Ohio Department of Transportation, 2014, invl, invm, and invs shapefiles: Ohio Department of Transportation, Division of Planning, Office of Technical Services web page, accessed April 12, 2018, at http://www.dot.state.oh.us/Divisions/ Planning/TechServ/TIM/Documents/Forms/AllItems.aspx? RootFolder $=\% 2$ FDivisions $\% 2$ FPlanning\%2FTechServ $\% 2 F$ TIM\%2FDocuments\%2FESRIDwnlds\%2FNew\%5FShape $\% 5$ FFiles $\% 5$ F.

Ohio Environmental Protection Agency (OEPA), 2014, Drilling for natural gas in the Marcellus and Utica ShalesEnvironmental Regulatory Basics: Fact sheet, 6 p., accessed April 12, 2018, at http://www.epa.ohio.gov/Portals/0/ general\%20pdfs/generalshale711.pdf.

Ohio Environmental Protection Agency (OEPA), 2017a, Biological and water quality study of the Stillwater Creek Basin, 2012, 82 p.: Ohio EPA Report EAS/2015-11-07.

Ohio Environmental Protection Agency (OEPA), 2017b, Developing rules to reduce the impacts of nutrients in surface waters, Ohio Environmental Protection Agency web page: accessed September 7, 2017, at http://www.epa.ohio. gov/dsw/dswrules/nutrientcriteria.aspx.

Ohio Oil and Gas Association, 2013, Overview of Ohio oil and natural gas in Presentation to American Association of Energy Engineers: Cleveland, Ohio, April 5, 2013, American Association of Energy Engineers: accessed December 15, 2017, at http://www.aeeohio.com/OOGA_SHALE\%20 OIL\%20AND\%20GAS_05022103.pdf.

Panno, S.V., Hackley, K.C., Hwang, H.H., Greenberg, S., Krapac, I.G., Landsberger, S., and O'Kelly, D.J., 2005, Database for the characterization and identification of the sources of sodium and chloride in natural waters of Illinois: Illinois State Geological Survey Open-File Series 2005-1, $15 \mathrm{p}$.

Patton, C.J., and Kryskalla, J.R., 2003, Methods of analysis by the U.S. Geological Survey National Water Quality Laboratory-Evaluation of alkaline persulfate digestion as an alternative to Kjeldahl digestion for determination of total and dissolved nitrogen and phosphorus in water: U.S. Geological Survey Water-Resources Investigations Report 03-4174, $33 \mathrm{p}$.

Patton, C.J., and Kryskalla, J.R., 2011, Colorimetric determination of nitrate plus nitrite in water by enzymatic reduction, automated discrete analyzer methods: U.S. Geological Survey Techniques and Methods, book 5, chap. B8, 34 p.

Pfaff, C.L., Helsel, D.R., Johnson, D.P., and Angelo, C.G., 1981, Assessment of water quality in streams draining coalproducing areas in Ohio: U.S. Geological Survey WaterResources Investigations Report 81-409, 98 p.
Risch, M.R., and Robinson, B.A., 2000, Use of borehole and surface geophysics to investigate ground-water quality near a road-deicing salt-storage facility, Valparaiso, Indiana: U.S. Geological Survey Water-Resources Investigations Report 00-4070, 65 p., accessed February 23, 2018, at https://pubs.er.usgs.gov/publication/wri004070.

Rowan, E.L., Engle, M.A., Kirby, C.S., and Kraemer, T.F., 2011, Radium content of oil- and gas-field produced waters in the northern Appalachian Basin (USA) - Summary and discussion of data: U.S. Geological Survey Scientific Investigations Report 2011-5135, $31 \mathrm{p}$.

RStudio, Inc., 2016, RStudio Version 1.0.136 [Computer software], Boston, MA.

Sedam, A.C., 1991, Geologic setting and water quality of selected basins in the active-coal-mining areas of Ohio, 1987-88: U.S. Geological Survey Water-Resources Investigations Report 90-4109, 97 p.

Sedam, A.C., and Francy, D.S., 1993, Geologic setting and water quality of selected basins in the active coal-mining areas of Ohio, 1989-91, with a summary of water quality for 1985-91: U.S. Geological Survey Water-Resources Investigations Report 93-4094, 133 p.

Shi, J., Douglas, R., Rippey, B., and Jordan, P., 2003, Modelling the diurnal variation of dissolved oxygen concentration in the River Oona: Transactions on Ecology and the Environment, v. 65, p. 403-412, accessed January 2, 2018, at https://www.witpress.com/Secure/elibrary/papers/WP03/ WP03039FU.pdf.

Statistical Analysis System (SAS) Institute Inc., 2016, JMP version 13.0.0 [Computer software], Cary, N.C.

Struzeski, T.M., DeGiacomo, W.J., and Zayhowski, E.J., 1996, Methods of analysis by the U.S. Geological Survey National Water Quality Laboratory-Determination of dissolved aluminum and boron in water by inductively coupled plasma-atomic emission spectrometry: U.S. Geological Survey Open-File Report 96-149, 17 p.

Stucker, J.D., compiler, 2016, 2015 Report on Ohio mineral industries-An annual summary of the state's economic geology: Columbus, Ohio Department of Natural Resources, Division of Geological Survey, 25 p., accessed April 12, 2018, at http://geosurvey.ohiodnr.gov/portals/ geosurvey/PDFs/Mineral_Industries_Reports/MinInd15.pdf.

Todd, D.K., 1980, Groundwater hydrology: New York, John Wiley and Sons, 539 p.

Tomastik, T., 2010, Ohio's regulations on natural gas development and disposal of oilfield wastes: Department of Natural Resources, online slide presentation, accessed April 6, 2010, at http://columbiana-health.org/documents/ ohio_regulations_natural_gas.pdf. 
Turnipseed, D.P., and Sauer, V.B., 2010, Discharge measurements at gaging stations: U.S. Geological Survey Techniques and Methods, book 3, chap. A8, 87 p.

U.S. Army Corps of Engineers (USACE), 2016, Potential hydrogen sulfide (H2S) concern at Atwood and Leesville Lakes: Huntington District news release no. PA 16-031, accessed April 12, 2018, at http://www.lrh.usace.army.mil/ Media/News-Releases/Article/821669/potential-hydrogensulfide-h2s-concern-at-atwood-and-leesville-lakes.

U.S. Army Corps of Engineers (USACE), 2017, Potential hydrogen sulfide (H2S) concern at Clendening, Leesville, and Piedmont: Huntington District news release no. 17-019, accessed April 12, 2018, at http://www.lrh.usace.army.mil/ Media/News-Releases/Article/1265953/potential-hydrogensulfide-h2s-concern-at-clendening-leesville-and-piedmont.

U.S. Army Corps of Engineers (USACE), 2018a, Lake temperature profile over time and lake dissolved oxygen profile over time, accessed January 5, 2018, at http://www.lrh-wc.usace.army.mil/wm/?basin.

U.S. Army Corps of Engineers (USACE), 2018b, Access to Water Resources Data, accessed May 25, 2017, at http://water.usace.army.mil.

U.S. Department of Energy, 2013, Modern shale gas development in the United States-An update: National Energy Technology Laboratory, 79 p., accessed April 12, 2018, at http://www.netl.doe.gov/File\%20Library/Research/Oil-Gas/ shale-gas-primer-update-2013.pdf.

U.S. Environmental Protection Agency, 1993, Method 365.1, Revision 2.0-Determination of phosphorus by semi-automated colorimetry: U.S. Environmental Protection Agency, accessed February 22, 2018, at https://www.epa.gov/sites/production/files/2015-08/ documents/method_365-1_1993.pdf.

U.S. Environmental Protection Agency, 2017, National recommended water quality criteria-Aquatic life criteria table, accessed April 12, 2018, at, https://www.epa.gov/wqc/ national-recommended-water-quality-criteria-aquatic-lifecriteria-table.

U.S. Geological Survey (USGS), 2005, The National Geologic Map Database, accessed April 12, 2018, at https://ngmdb.usgs.gov/ngmdb/ngmdb_home.html.

U.S. Geological Survey (USGS), 2017a, National Water Information System-Web Interface: U.S. Geological Survey web page, accessed April 12, 2018, at https://dx.doi.org/10.5066/F7P55KJN.
U.S. Geological Survey (USGS), 2017b, Quality Systems Branch: U.S. Geological Survey web page, accessed September 1, 2017, at https://bqs.usgs.gov.

U.S. Geological Survey (USGS), 2017c, Water properties-dissolved oxygen: U.S. Geological Survey web page, accessed January 2, 2018, at https://water.usgs.gov/edu/ dissolvedoxygen.html.

U.S. Geological Survey (USGS), variously dated, National field manual for the collection of water-quality data: U.S. Geological Survey Techniques of Water-Resources Investigations, book 9, chaps. A1-A10, accessed February 23, 2018, at https://water.usgs.gov/owq/FieldManual/.

Whittemore, D.O., 1988, Bromide as a tracer in ground-water studies - Geochemistry and analytical determination, in National Water Well Association, in Ground Water Geochemistry Conference, Denver, Colo., February 16-18, 1988, Proceedings: Denver, Colo., p. 339-359.

Wilde, F.D., Radtke, D.B., Gibs, Jacob, and Iwatsubo, R.T., eds., variously dated, Processing of water samples (version 2.2, with updates through February 2009): U.S. Geological Survey Techniques of Water-Resources Investigations, book 9, chap. A5, accessed February 2, 2015, at https://pubs.water.usgs.gov/twri9A5/.

Wilson, J.M., Wang, Y., and VanBriesen, J.M., 2014, Sources of high total dissolved solids to drinking water supply in southwestern Pennsylvania: Journal of Environmental Engineering, v. 140, no. 5.

Wyrick, G.G., and Borchers, J.W., 1981, Hydrologic effects of stress relief fracturing in an Appalachian valley: U.S. Geological Survey Water-Supply Paper 2177, 51 p.

Zimmerman, C.F., Keefe, C.W., and Bashe, J., 1997, Method 440.0 - Determination of carbon and nitrogen in sediments and particulates of estuarine/coastal waters using elemental analysis: Washington D.C., U.S. Environmental Protection Agency, EPA/600/R-15/009.

Zogorski, J.S., Carter, J.M., Ivahnenko, T., Lapham, W.W., Moran, M.J., Rowe, B.L., Squillace, P.J., and Toccalino, P.L., 2006, The quality of our Nation's waters-Volatile organic compounds in the Nation's ground water and drinking-water supply wells: U.S. Geological Survey Circular 1292, $101 \mathrm{p}$. 

Appendixes 1-3 


\section{Appendix 1. Six Discrete Values of Stream Stage and Specific Conductance at Each Site were Compared to Hourly Measurements of Stream Stage and Specific Conductance at Each of the 14 Water-Quality Gages}
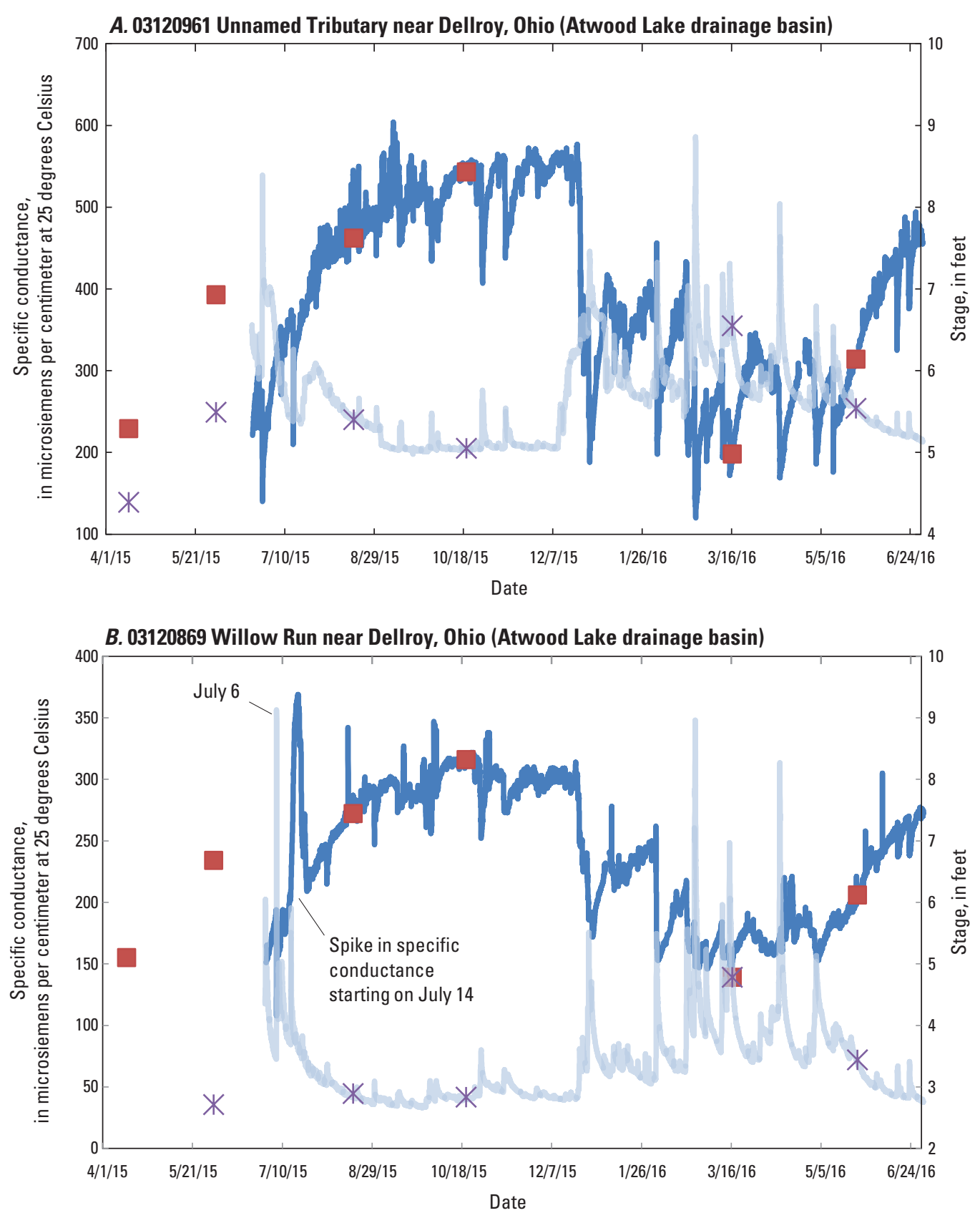

EXPLANATION

$\begin{array}{lll}\text { Specific conductance, continuous monitor } & \text { Specific conductance, discrete stream samples } \\ \text { Stage, continuous monitor } & * \quad \text { Stage, discrete samples }\end{array}$

Figure 1.1. Continuous and discrete measurements of specific conductance as a function of stream stage at selected tributaries, Muskingum River watershed, April 2015-June 2016. A, 03120961 Unnamed Tributary near Dellroy, Ohio; and B, 03120869 Willow Run near Dellroy, Ohio. 
C. 03120820 Indian Fork at Dellroy, Ohio (Atwood Lake drainage basin)

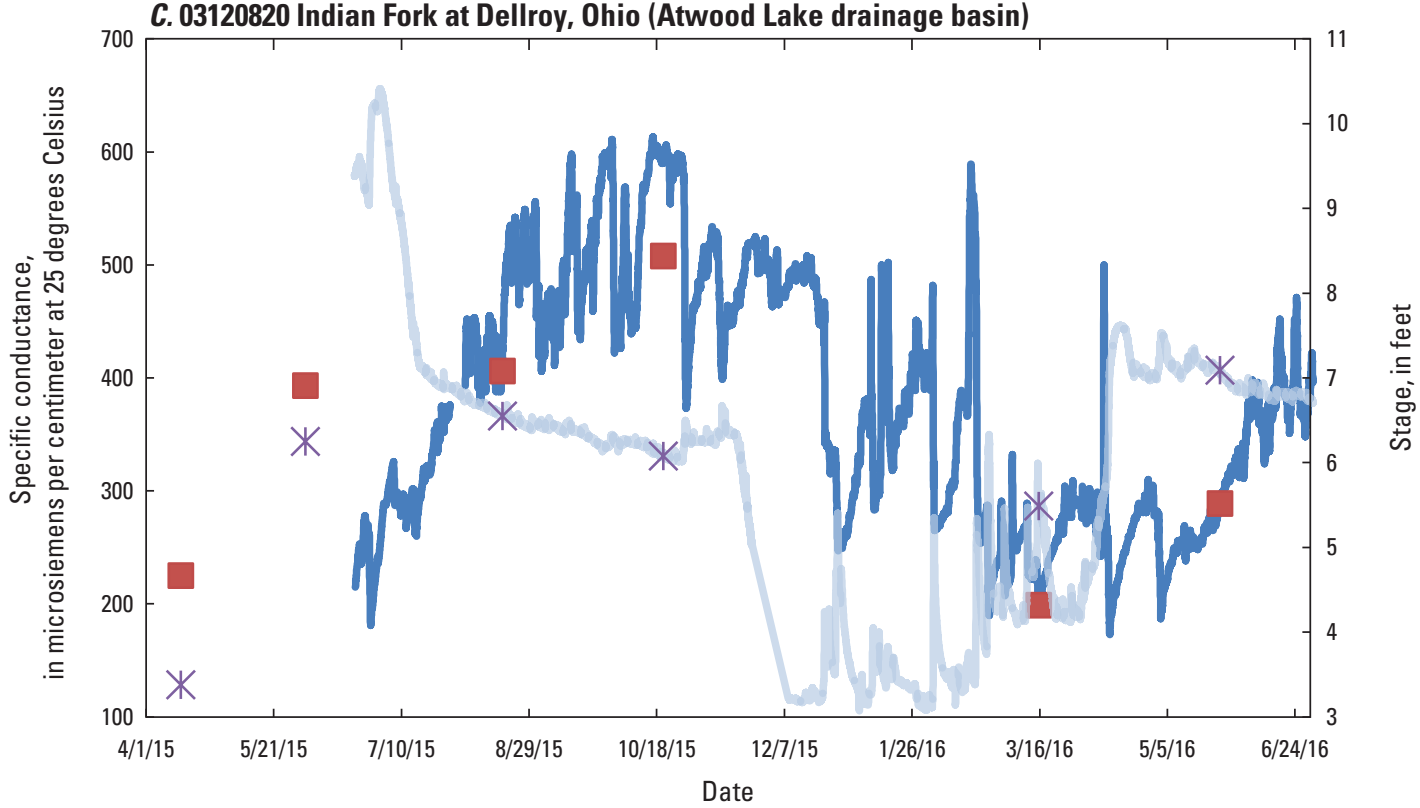

D. 03119979 Bear Hole Run near Carrollton, Ohio (Leesville Lake drainage basin)

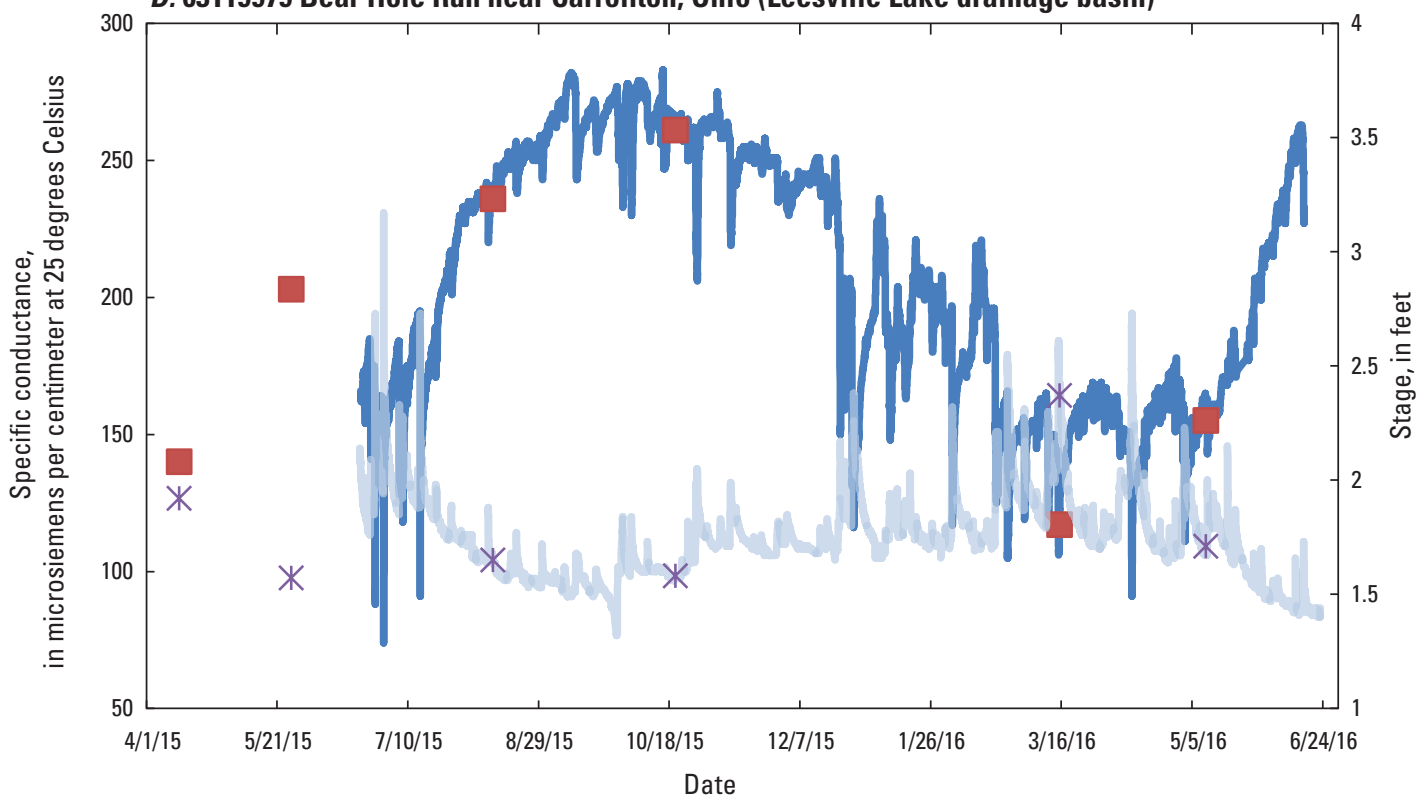

EXPLANATION

Specific conductance, continuous monito

Stage, continuous monitor
- Specific conductance, discrete stream samples

* Stage, discrete samples

Figure 1.2. Continuous and discrete measurements of specific conductance as a function of stream stage at selected tributaries, Muskingum River watershed, April 2015-June 2016. C, 03120820 Indian Fork at Dellroy, Ohio; and D, 03119979 Bear Hole Run near Carrollton, Ohio. 

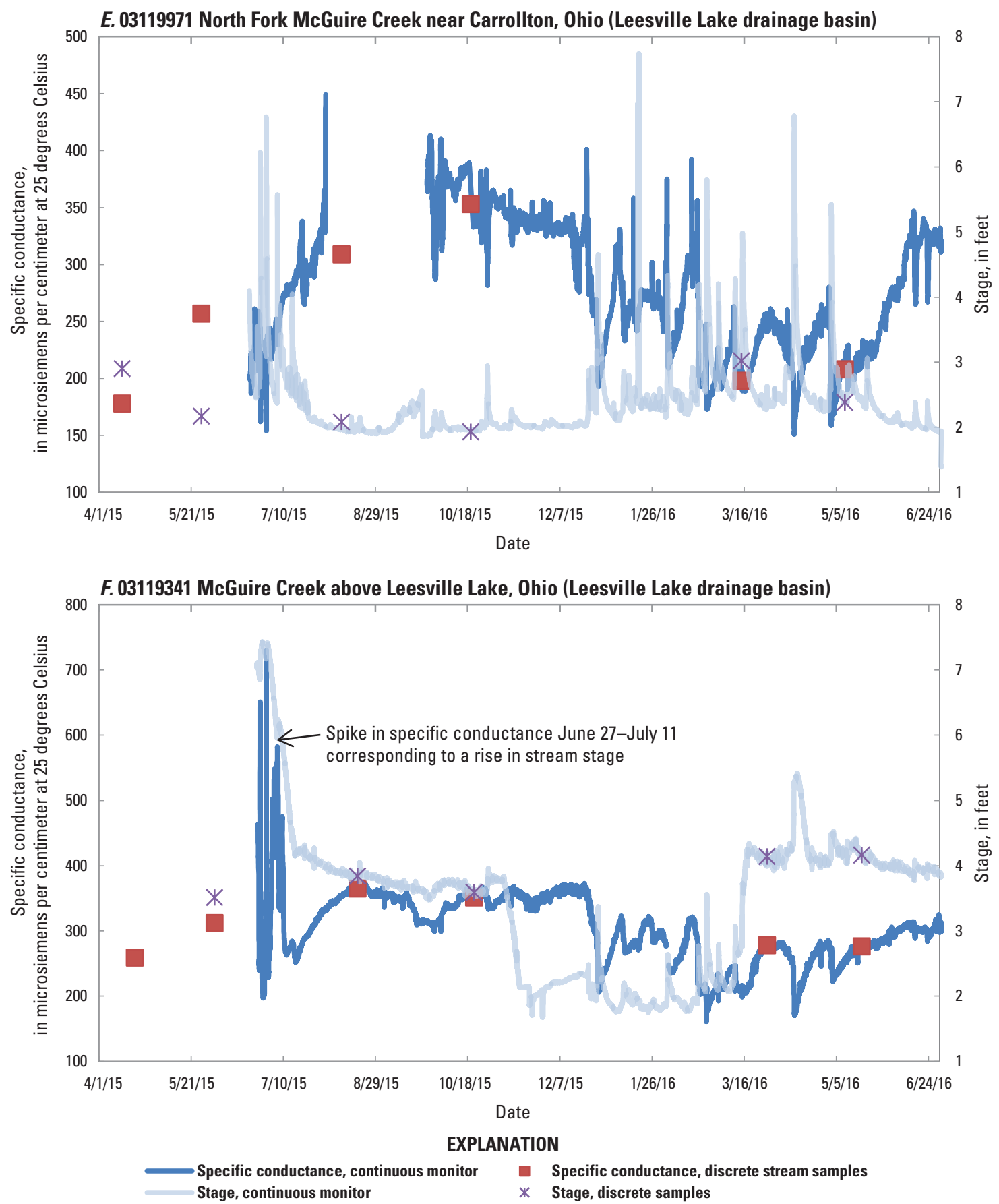

Figure 1.3. Continuous and discrete measurements of specific conductance as a function of stream stage at selected tributaries, Muskingum River watershed, April 2015-June 2016. E, 03119971 North Fork McGuire Creek near Carrollton, Ohio; and F, 03119341 McGuire Creek above Leesville Lake, Ohio. 
G. 03127989 Beaverdam Run above Tappan Lake, Ohio
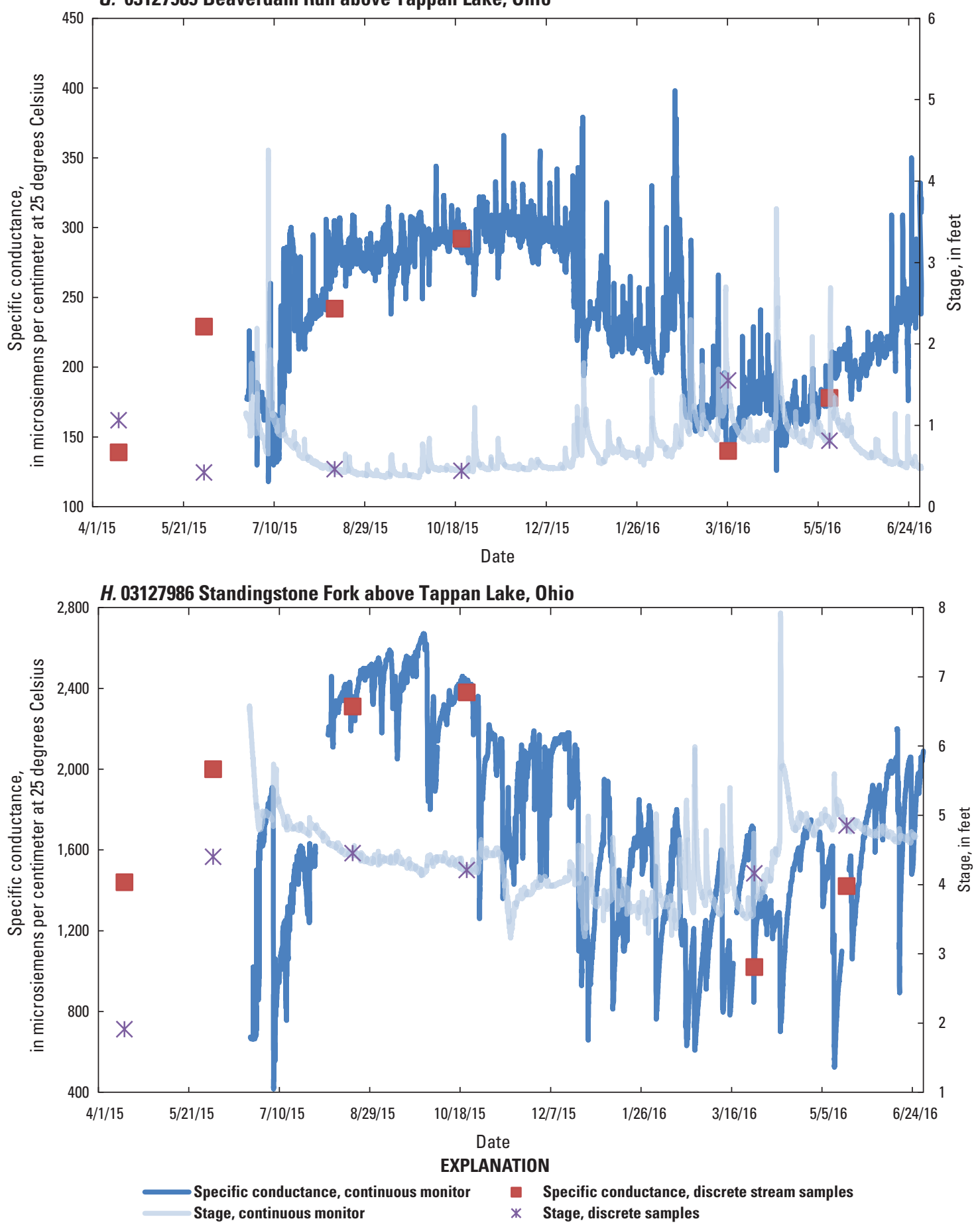

Figure 1.4. Continuous and discrete measurements of specific conductance as a function of stream stage at selected tributaries, Muskingum River watershed, April 2015-June 2016. G, 03127989 Beaverdam Run above Tappan Lake, Ohio; and H, 03127986 Standingstone Fork above Tappan Lake, Ohio. 

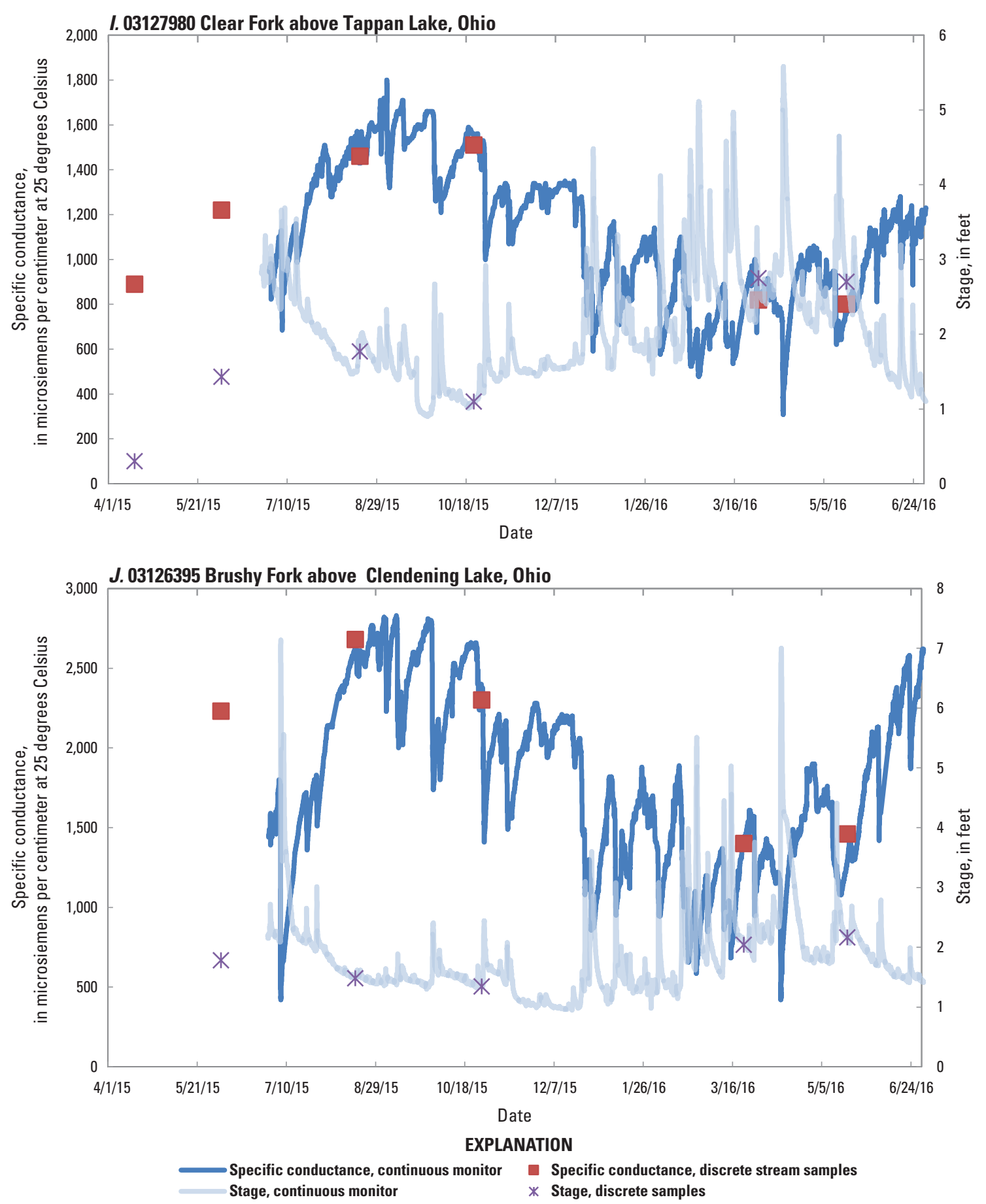

Figure 1.5. Continuous and discrete measurements of specific conductance as a function of stream stage at selected tributaries, Muskingum River watershed, April 2015-June 2016. I, 03127980 Clear Fork above Tappan Lake, Ohio; and J, 03126395 Brushy Fork above Clendening Lake, Ohio. 

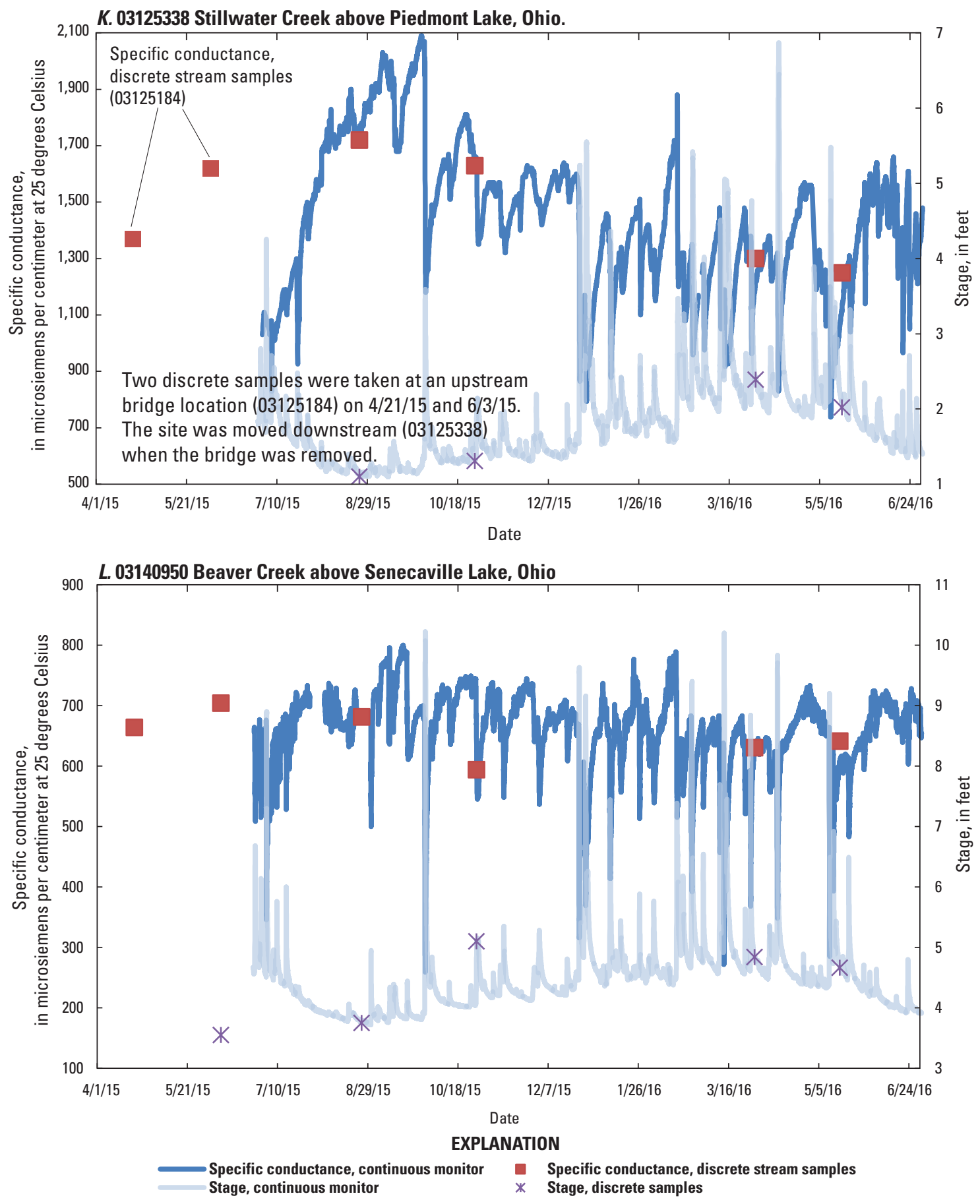

Figure 1.6. Continuous and discrete measurements of specific conductance as a function of stream stage at selected tributaries, Muskingum River watershed, April 2015-June 2016. K, 03125338 Stillwater Creek above Piedmont Lake, Ohio; and L, 03140950 Beaver Creek above Senecaville Lake, Ohio. 

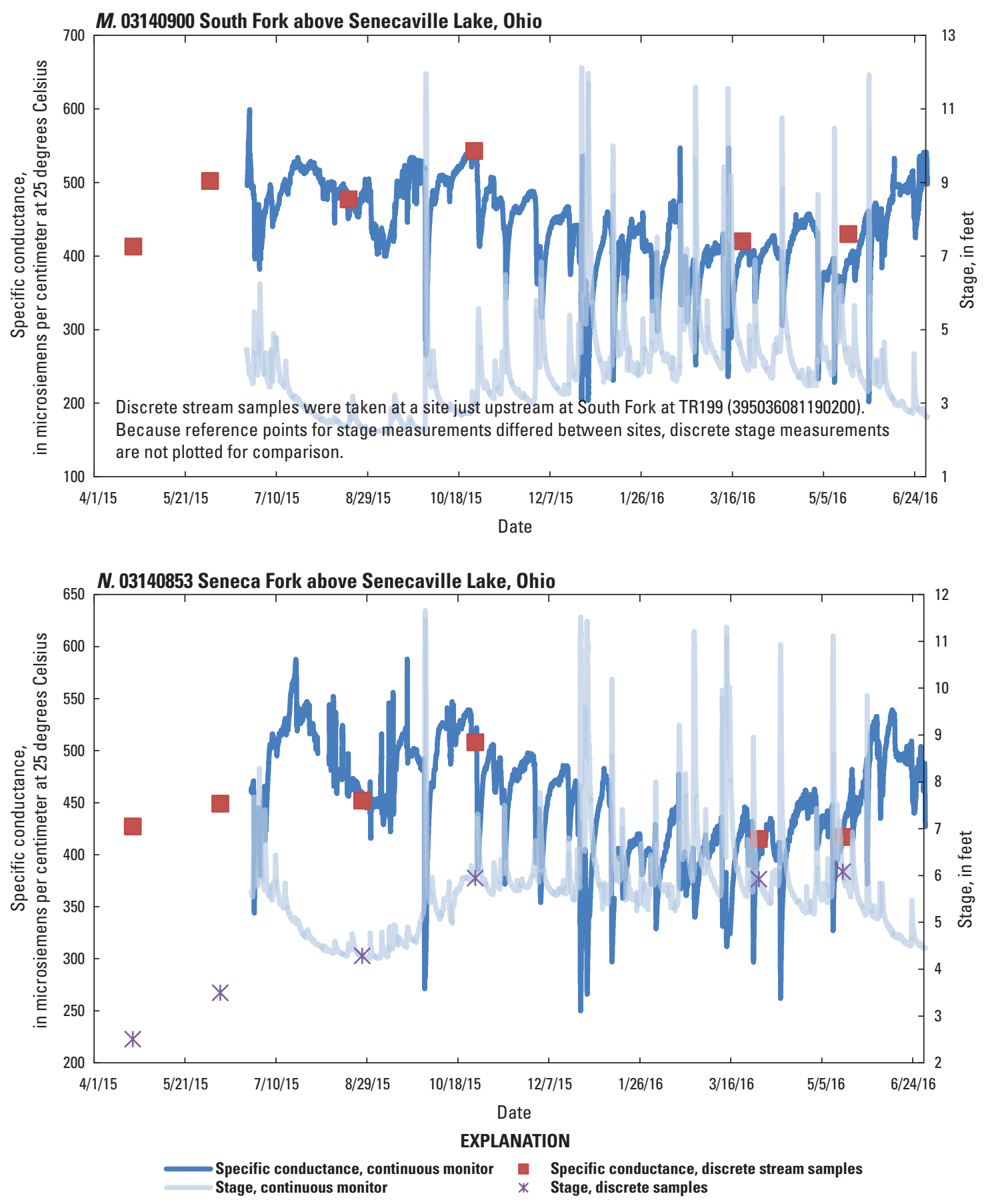

Figure 1.7. Continuous and discrete measurements of specific conductance as a function of stream stage at selected tributaries, Muskingum River watershed, April 2015-June 2016. M, 03140900 South Fork above Senecaville Lake, Ohio; and N, 03140853 Seneca Fork above Senecaville Lake, Ohio. 


\section{Appendix 2. Boxplots of Concentrations or Levels of Constituents and Properties}

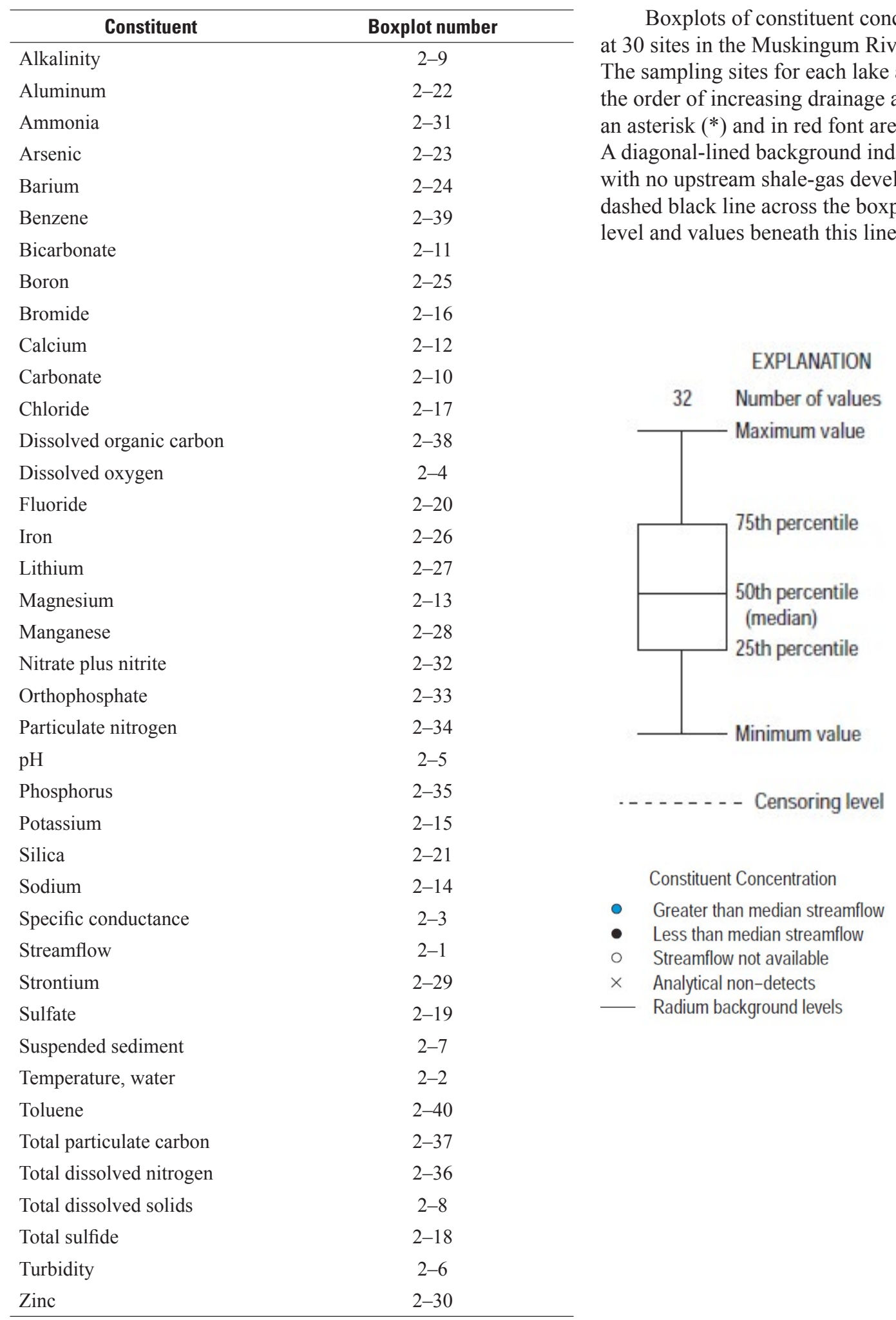



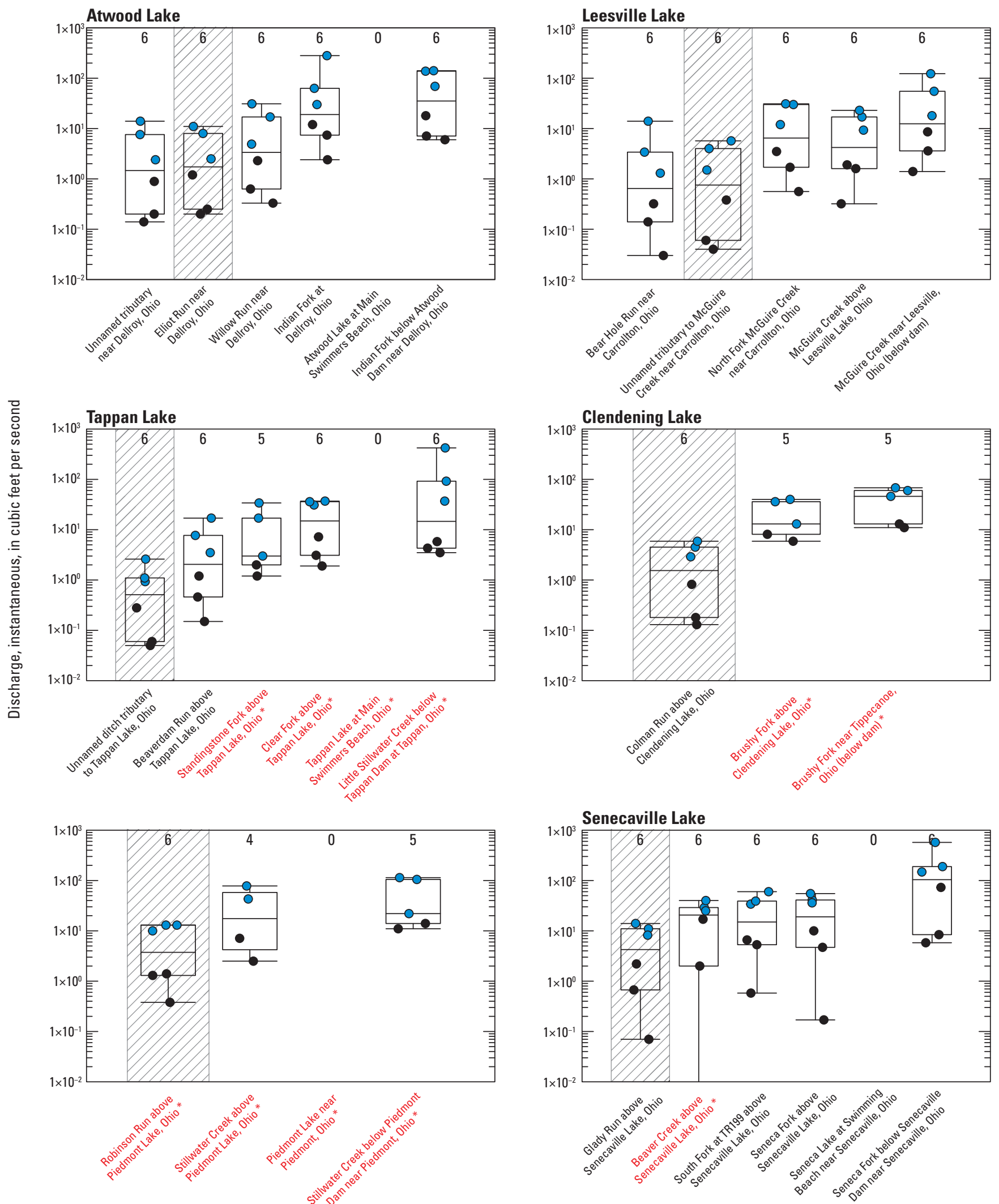

Sites ordered, left to right, from smallest to largest drainage area

Figure 2.1. Discharge at 30 sites in the Muskingum River watershed, Ohio, 2015-16. The sampling sites for each lake are arranged left-to-right in the order of increasing drainage area. Site names followed by an asterisk (*) and in red font are classified as mineimpacted sites. A diagonal-lined background indicates a reference site (site with no upstream shale-gas development). When applicable, the reporting level has been displayed as a dashed black line across the boxplots and censored values beneath this line have not been shown. 

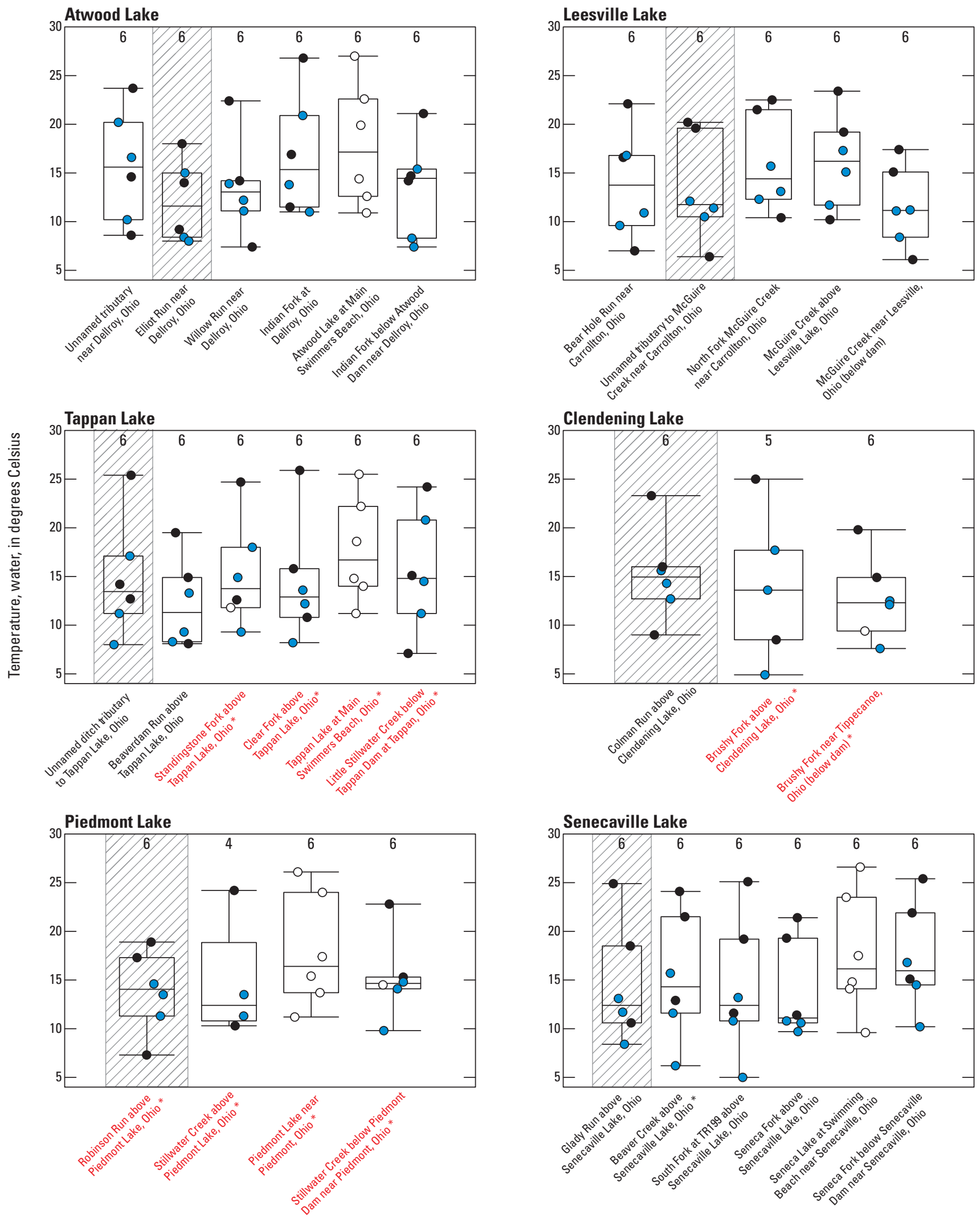

Sites ordered, left to right, from smallest to largest drainage area

Figure 2.2. Temperature (water) at 30 sites in the Muskingum River watershed, Ohio, 2015-16. The sampling sites for each lake are arranged left-to-right in the order of increasing drainage area. Site names followed by an asterisk $\left.{ }^{*}\right)$ and in red font are classified as mine-impacted sites. A diagonal-lined background indicates a reference site (site with no upstream shale-gas development). When applicable, the reporting level has been displayed as a dashed black line across the boxplots and censored values beneath this line have not been shown. 

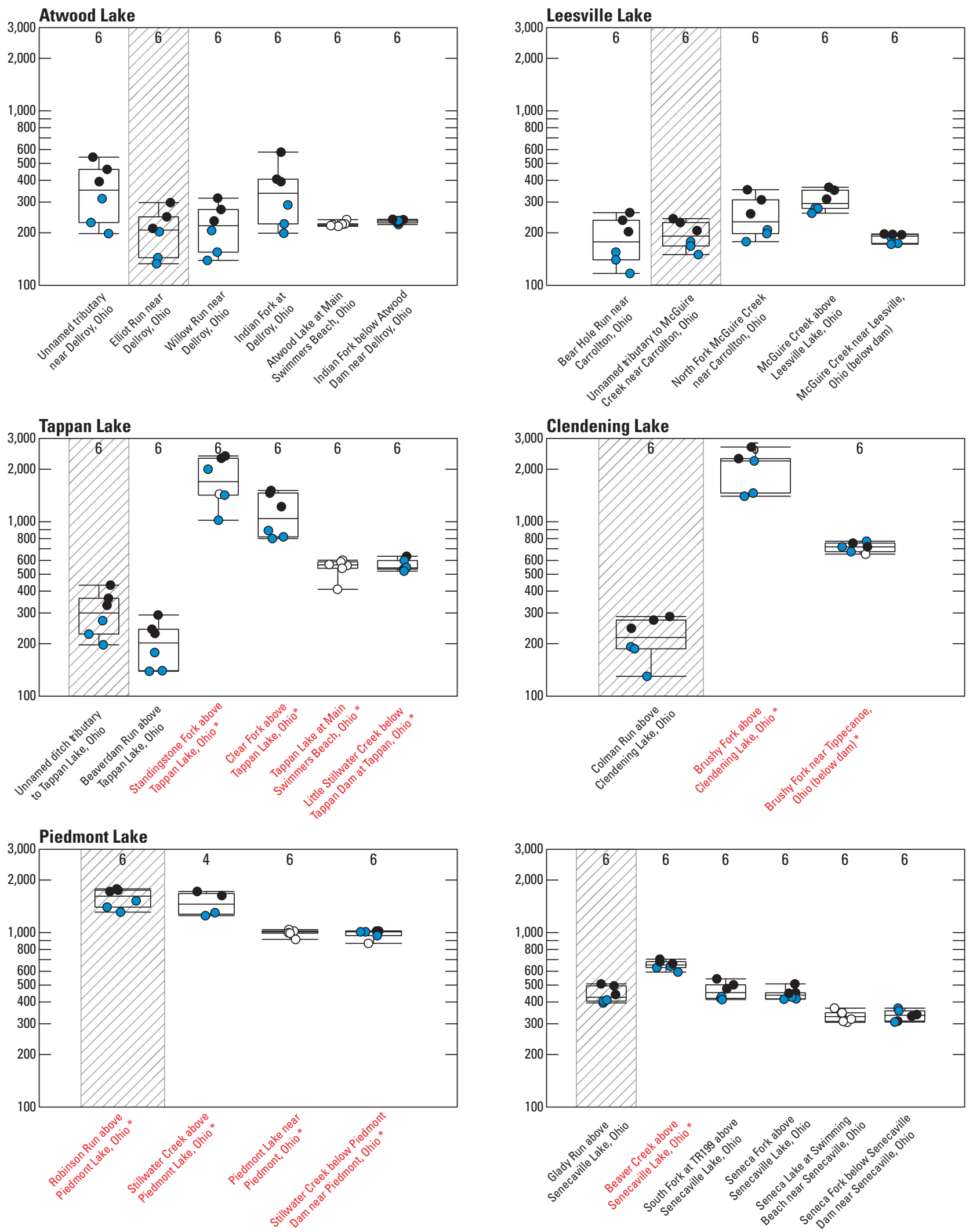

Sites ordered, left to right, from smallest to largest drainage area

Figure 2.3. Specific conductance measurements at 30 sites in the Muskingum River watershed, 0hio, 2015-16. The sampling sites for each lake are arranged left-to-right in the order of increasing drainage area. Site names followed by an asterisk $\left({ }^{*}\right)$ and in red font are classified as mine-impacted sites. A diagonal-lined background indicates a reference site (site with no upstream shale-gas development). When applicable, the reporting level has been displayed as a dashed black line across the boxplots and censored values beneath this line have not been shown. 

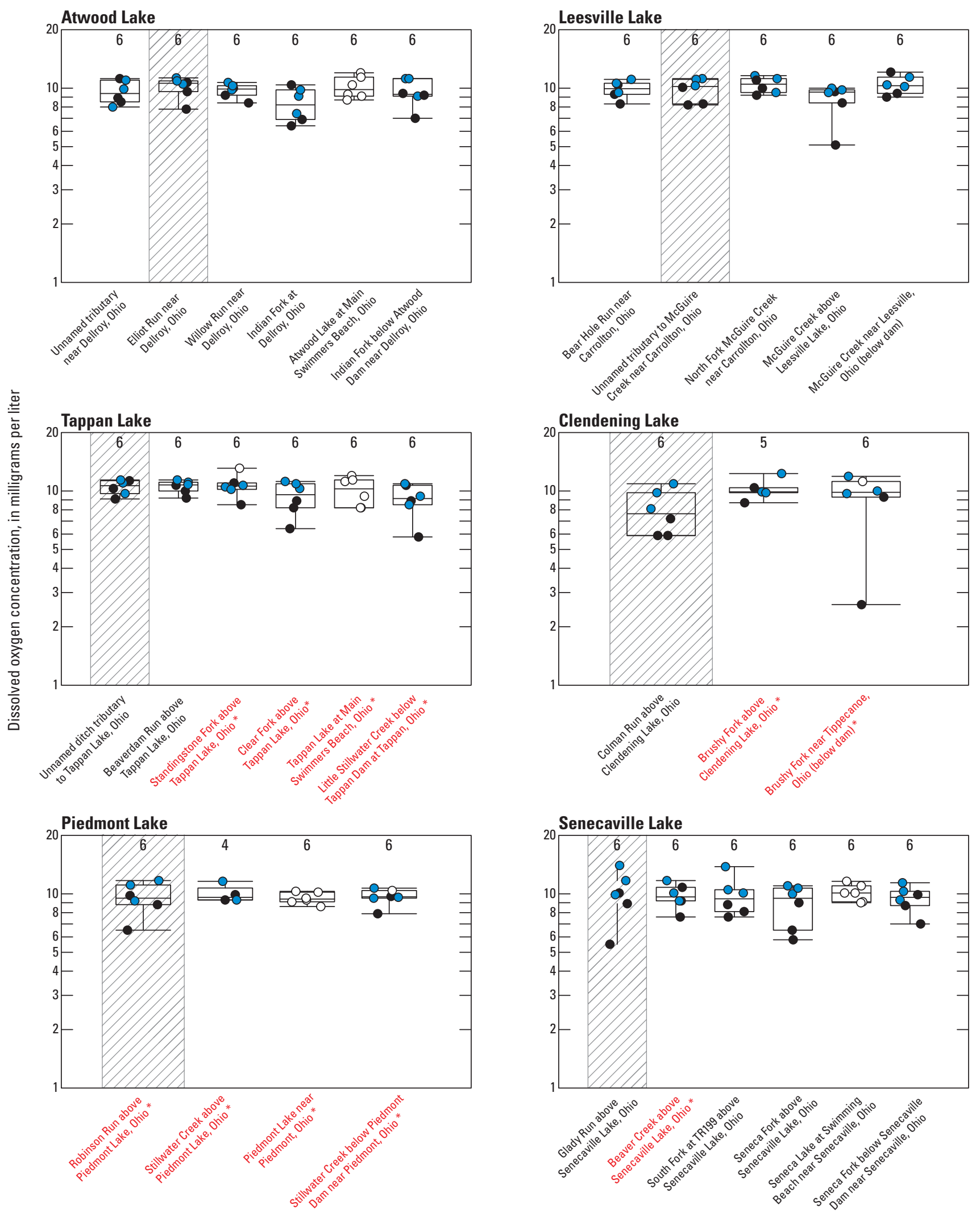

Sites ordered, left to right, from smallest to largest drainage area

Figure 2.4. Dissolved oxygen concentrations at 30 sites in the Muskingum River watershed, Ohio, 2015-16. The sampling sites for each lake are arranged left-to-right in the order of increasing drainage area. Site names followed by an asterisk (*) and in red font are classified as mine-impacted sites. A diagonal-lined background indicates a reference site (site with no upstream shale-gas development). When applicable, the reporting level has been displayed as a dashed black line across the boxplots and censored values beneath this line have not been shown. 

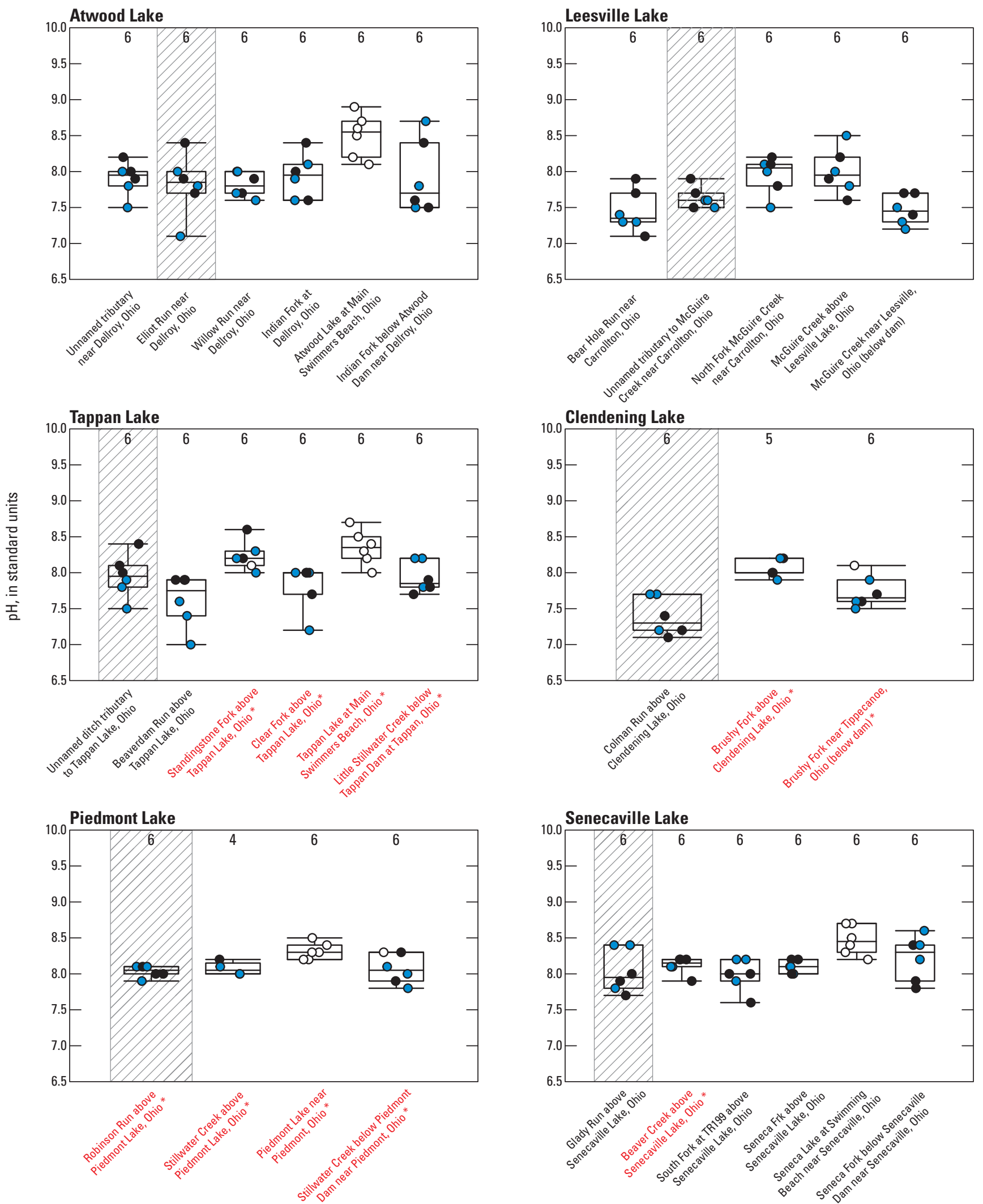

Sites ordered, left to right, from smallest to largest drainage area

Figure 2.5. $\mathrm{pH}$ measurements at 30 sites in the Muskingum River watershed, Ohio, 2015-16. The sampling sites for each lake are arranged left-to-right in the order of increasing drainage area. Site names followed by an asterisk $\left(^{*}\right)$ and in red font are classified as mine-impacted sites. A diagonal-lined background indicates a reference site (site with no upstream shale-gas development). When applicable, the reporting level has been displayed as a dashed black line across the boxplots and censored values beneath this line have not been shown. 

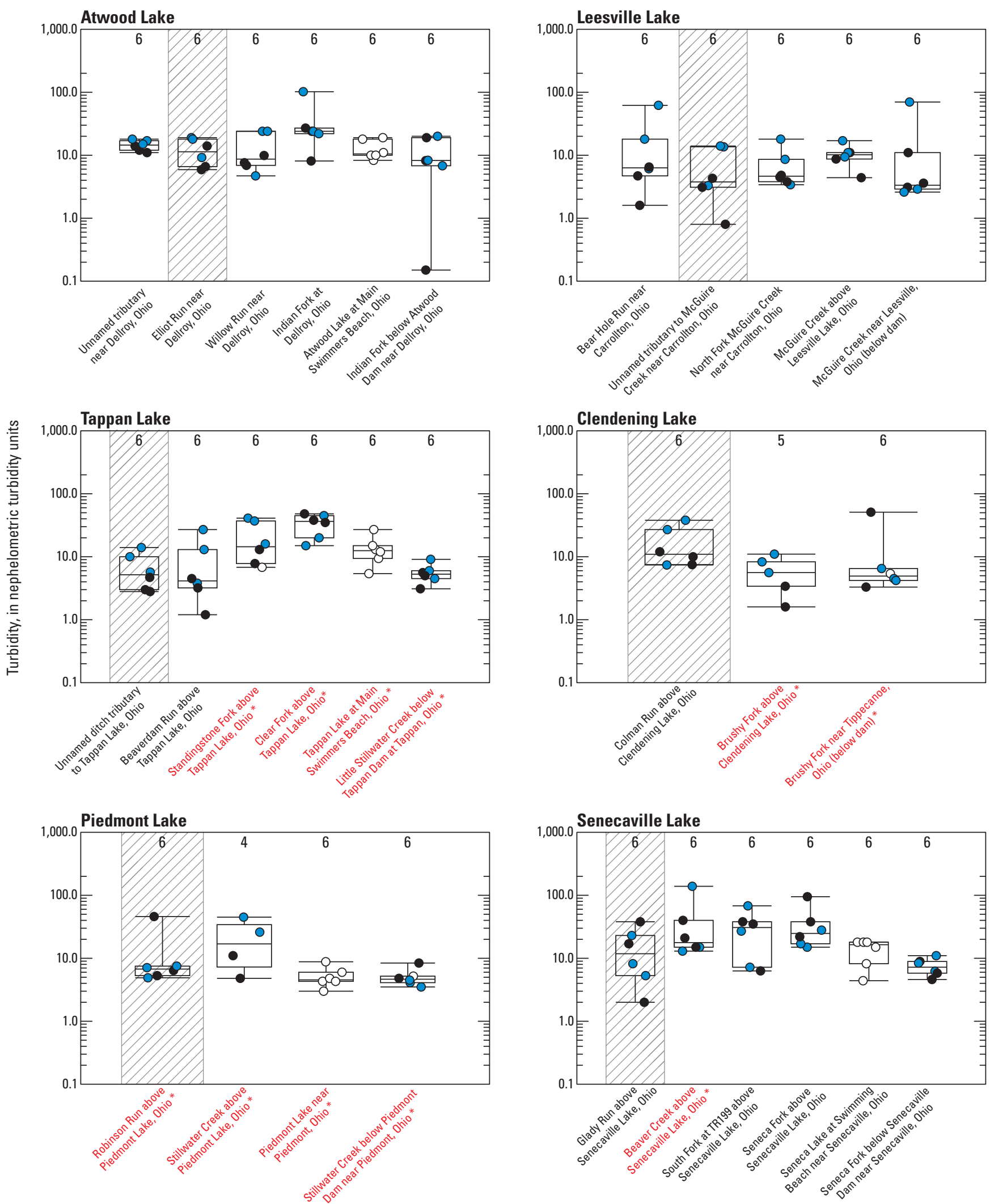

Sites ordered, left to right, from smallest to largest drainage area

Figure 2.6. Turbidity measurements at 30 sites in the Muskingum River watershed, Ohio, 2015-16. The sampling sites for each lake are arranged left-to-right in the order of increasing drainage area. Site names followed by an asterisk (*) and in red font are classified as mine-impacted sites. A diagonal-lined background indicates a reference site (site with no upstream shale-gas development). When applicable, the reporting level has been displayed as a dashed black line across the boxplots and censored values beneath this line have not been shown. 

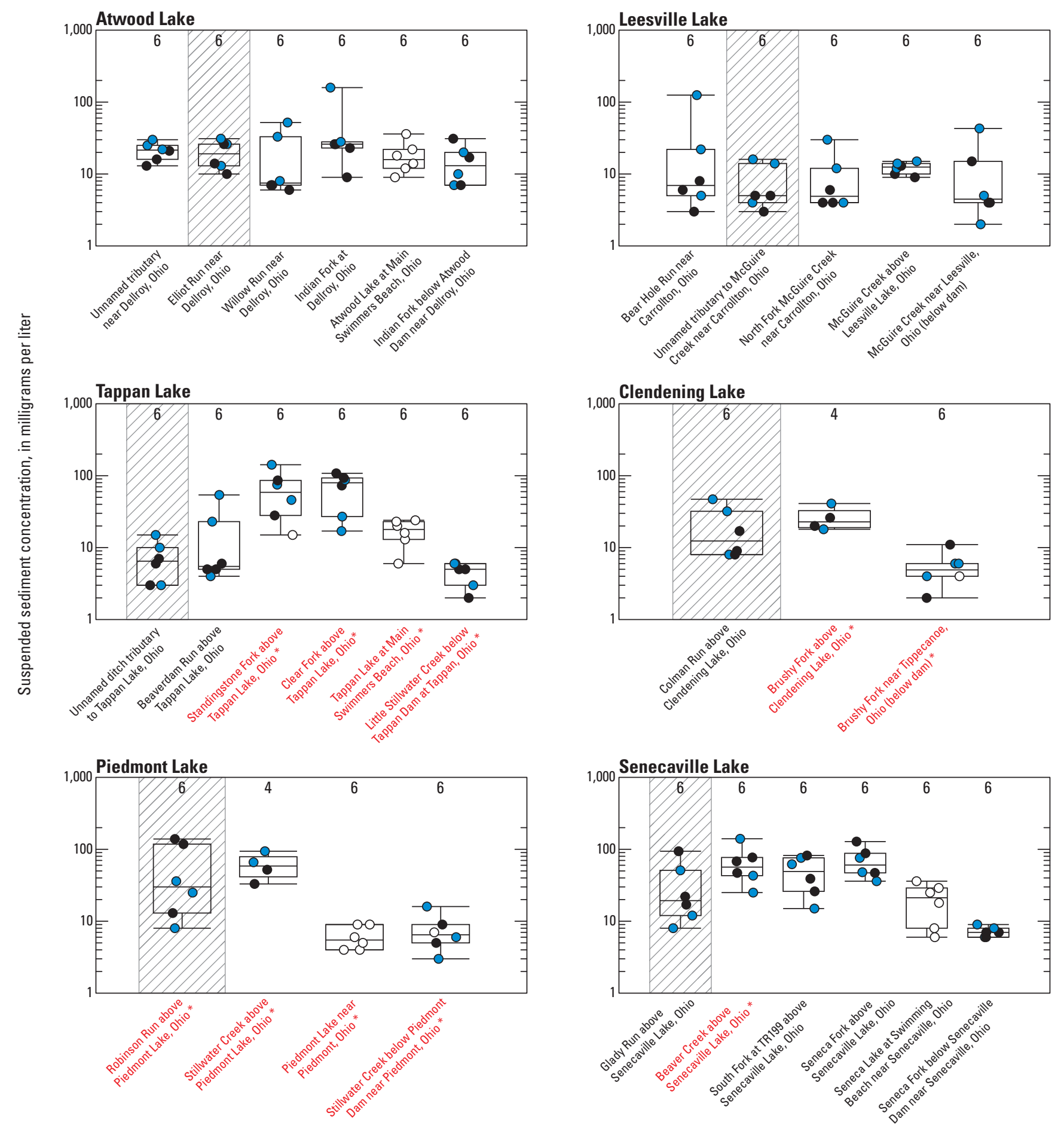

Sites ordered, left to right, from smallest to largest drainage area

Figure 2.7. Suspended sediment concentrations at 30 sites in the Muskingum River watershed, 0hio, 2015-16. The sampling sites for each lake are arranged left-to-right in the order of increasing drainage area. Site names followed by an asterisk $\left({ }^{*}\right)$ and in red font are classified as mine-impacted sites. A diagonal-lined background indicates a reference site (site with no upstream shale-gas development). When applicable, the reporting level has been displayed as a dashed black line across the boxplots and censored values beneath this line have not been shown. 

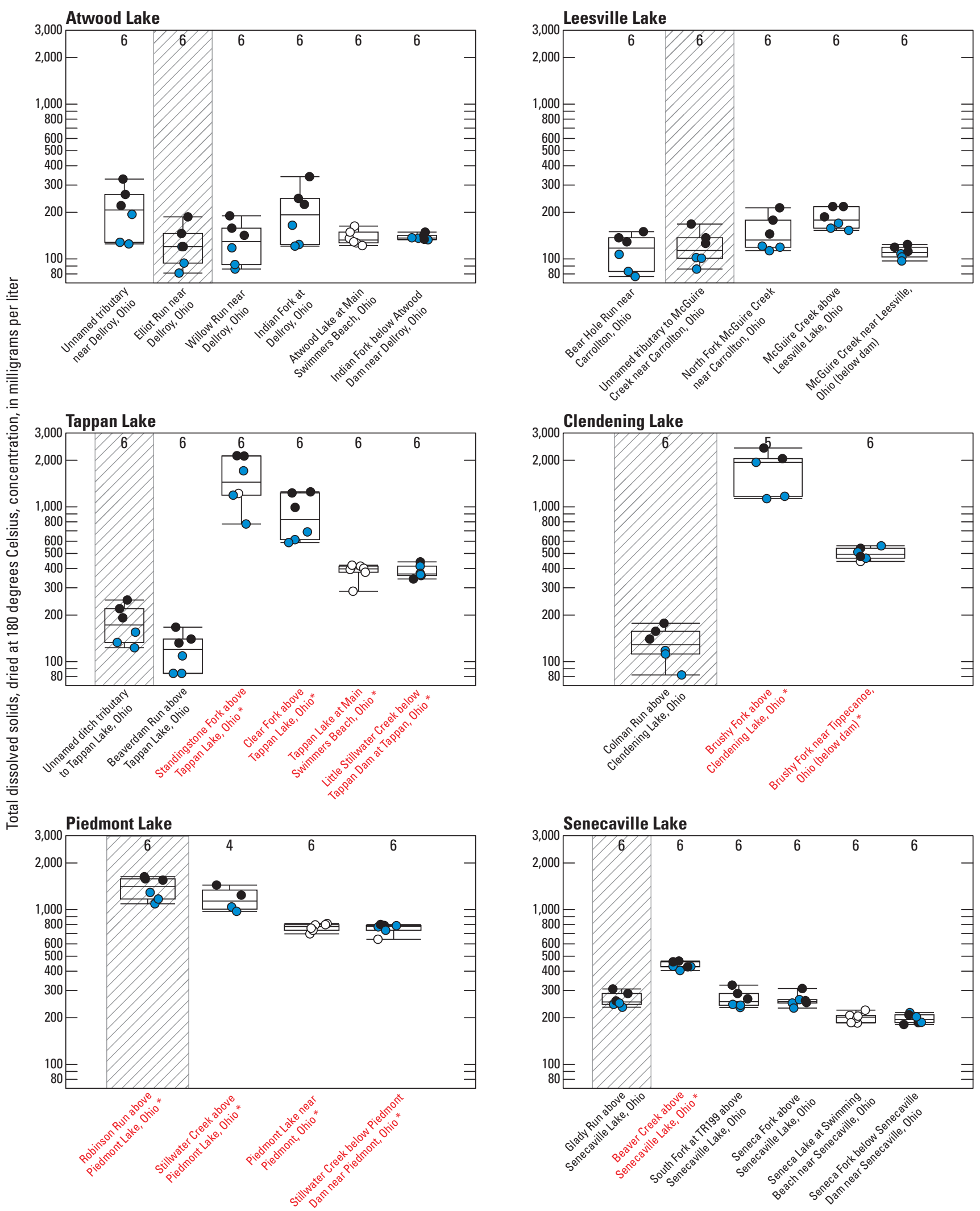

Sites ordered, left to right, from smallest to largest drainage area

Figure 2.8. Total dissolved solids concentrations at 30 sites in the Muskingum River watershed, Ohio, 2015-16. The sampling sites for each lake are arranged left-to-right in the order of increasing drainage area. Site names followed by an asterisk $\left({ }^{*}\right)$ and in red font are classified as mine-impacted sites. A diagonal-lined background indicates a reference site (site with no upstream shale-gas development). When applicable, the reporting level has been displayed as a dashed black line across the boxplots and censored values beneath this line have not been shown. 

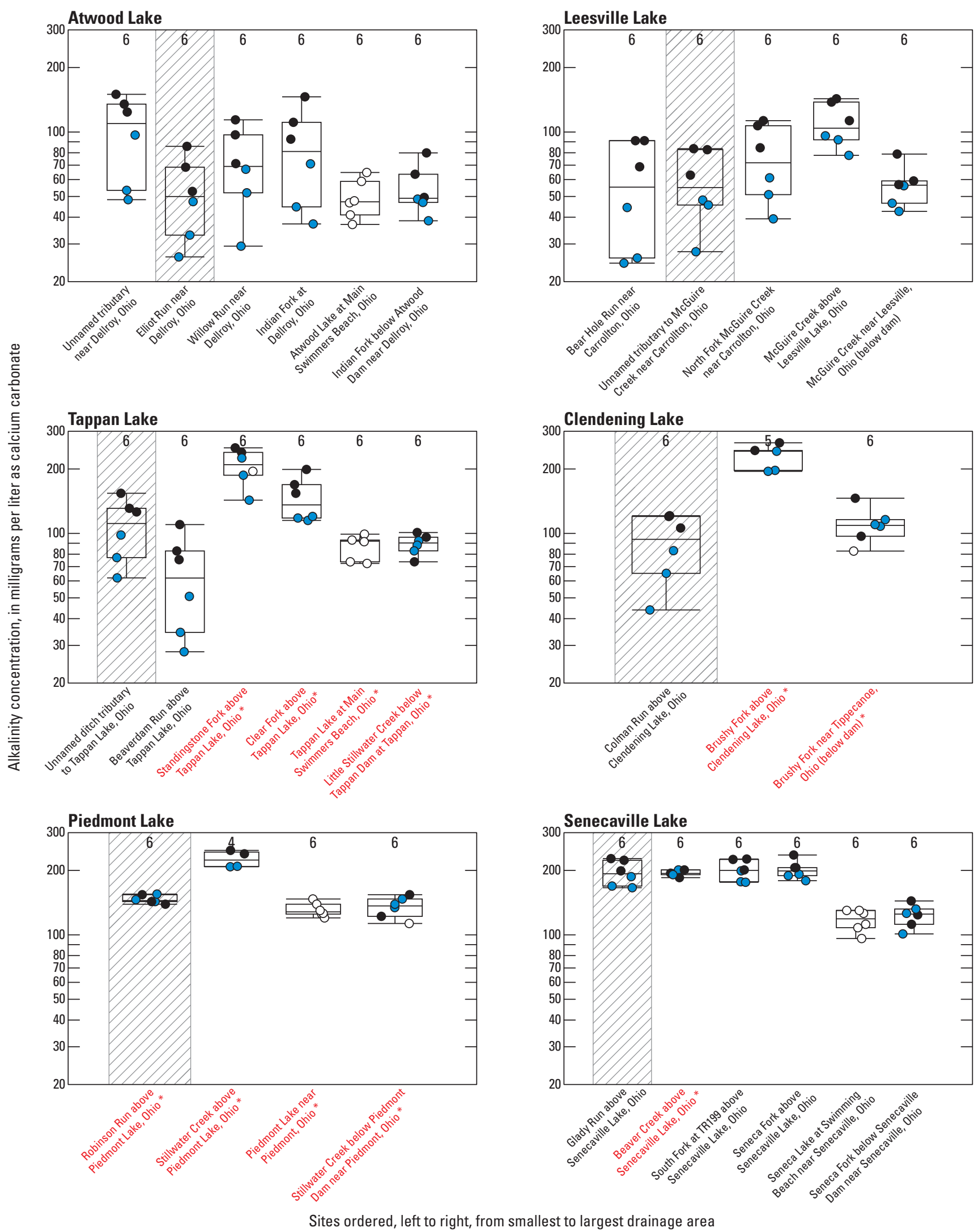

Figure 2.9. Alkalinity concentrations at 30 sites in the Muskingum River watershed, Ohio, 2015-16. The sampling sites for each lake are arranged left-to-right in the order of increasing drainage area. Site names followed by an asterisk $\left({ }^{*}\right)$ and in red font are classified as mine-impacted sites. A diagonal-lined background indicates a reference site (site with no upstream shale-gas development). When applicable, the reporting level has been displayed as a dashed black line across the boxplots and censored values beneath this line have not been shown. 

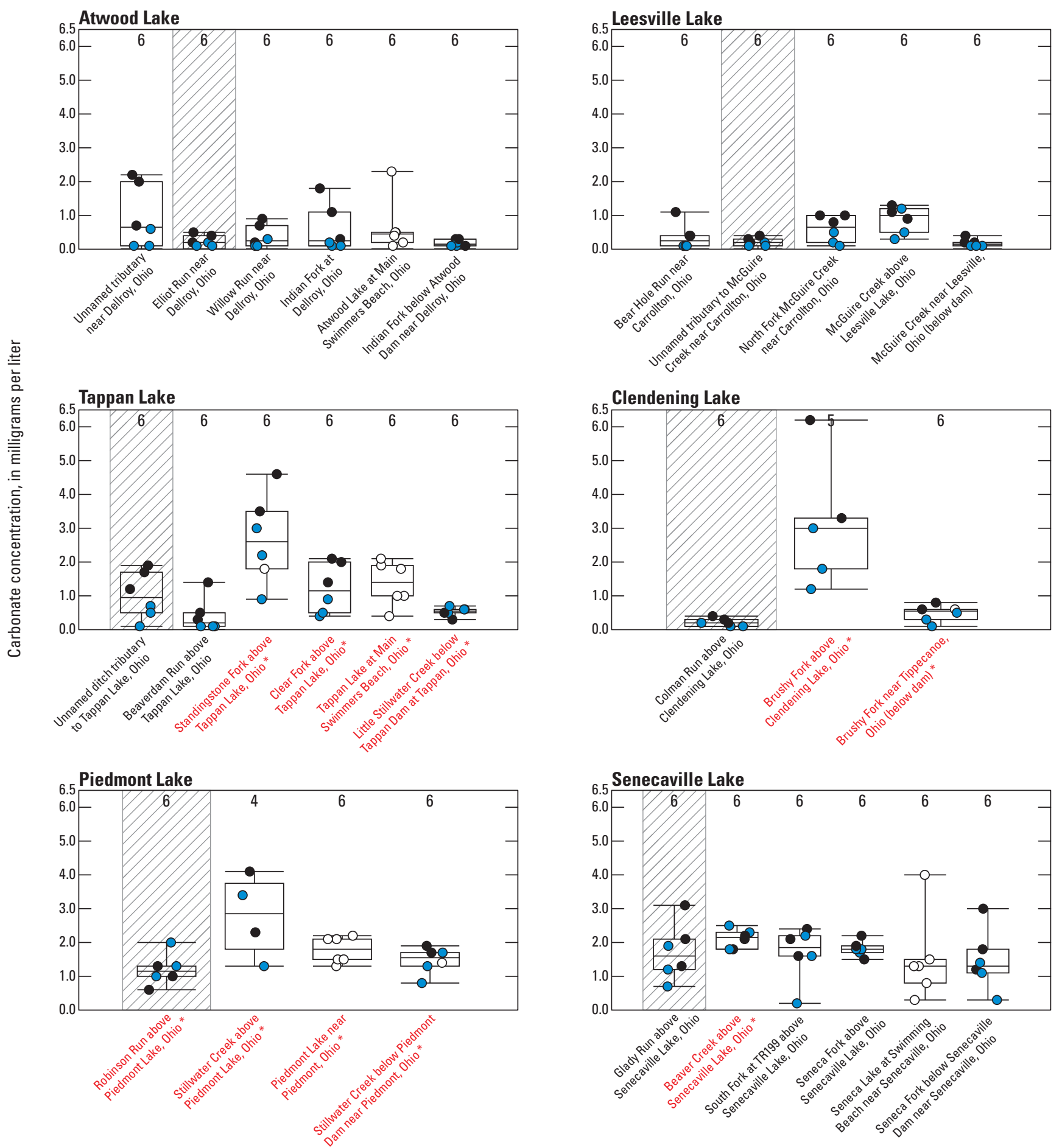

Sites ordered, left to right, from smallest to largest drainage area

Figure 2.10. Carbonate concentrations at 30 sites in the Muskingum River watershed, 0hio, 2015-16. The sampling sites for each lake are arranged left-to-right in the order of increasing drainage area. Site names followed by an asterisk (*) and in red font are classified as mine-impacted sites. A diagonal-lined background indicates a reference site (site with no upstream shale-gas development). When applicable, the reporting level has been displayed as a dashed black line across the boxplots and censored values beneath this line have not been shown. 

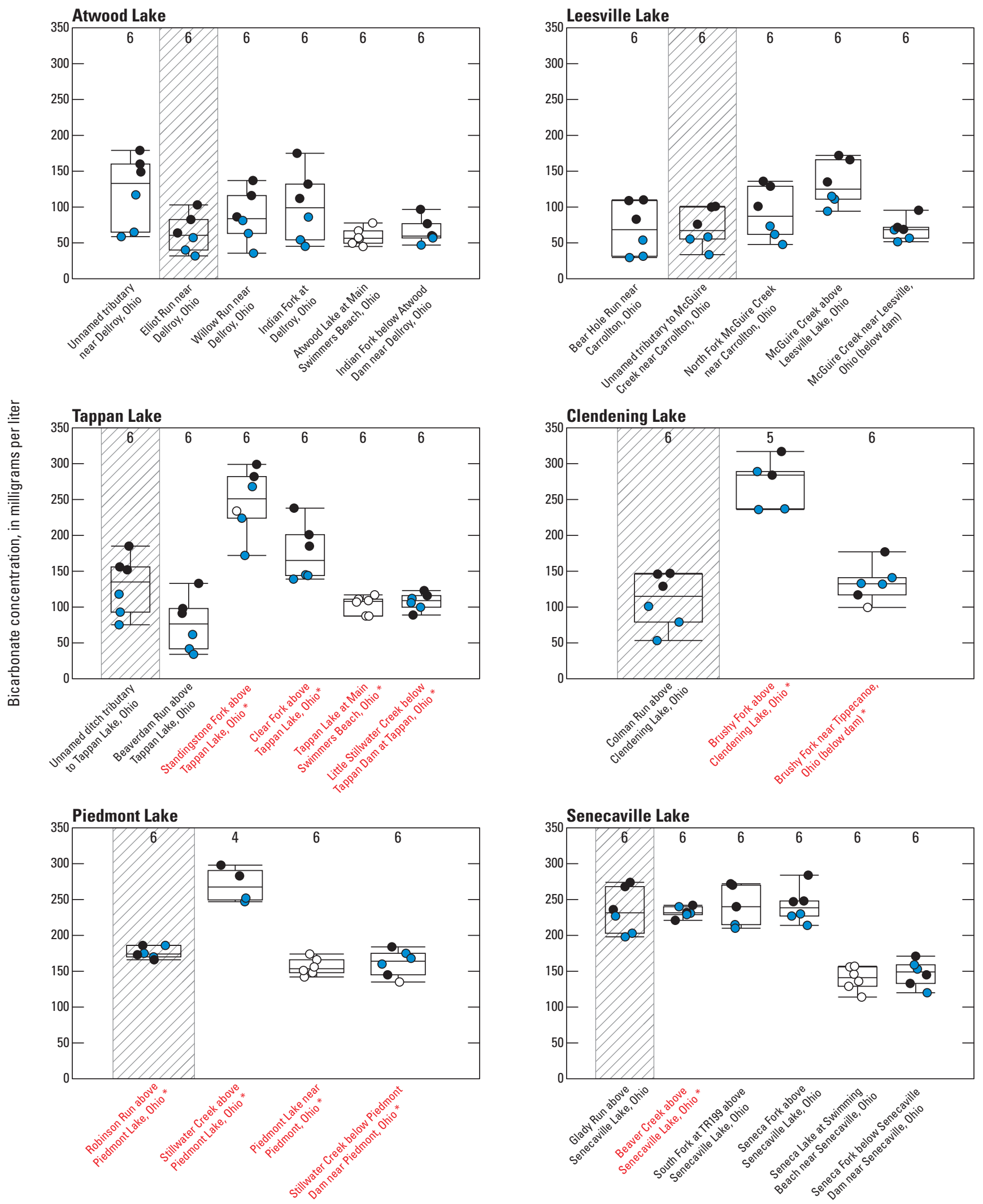

Sites ordered, left to right, from smallest to largest drainage area

Figure 2.11. Bicarbonate concentrations at 30 sites in the Muskingum River watershed, Ohio, 2015-16. The sampling sites for each lake are arranged left-to-right in the order of increasing drainage area. Site names followed by an asterisk $\left({ }^{*}\right)$ and in red font are classified as mine-impacted sites. A diagonal-lined background indicates a reference site (site with no upstream shale-gas development). When applicable, the reporting level has been displayed as a dashed black line across the boxplots and censored values beneath this line have not been shown. 

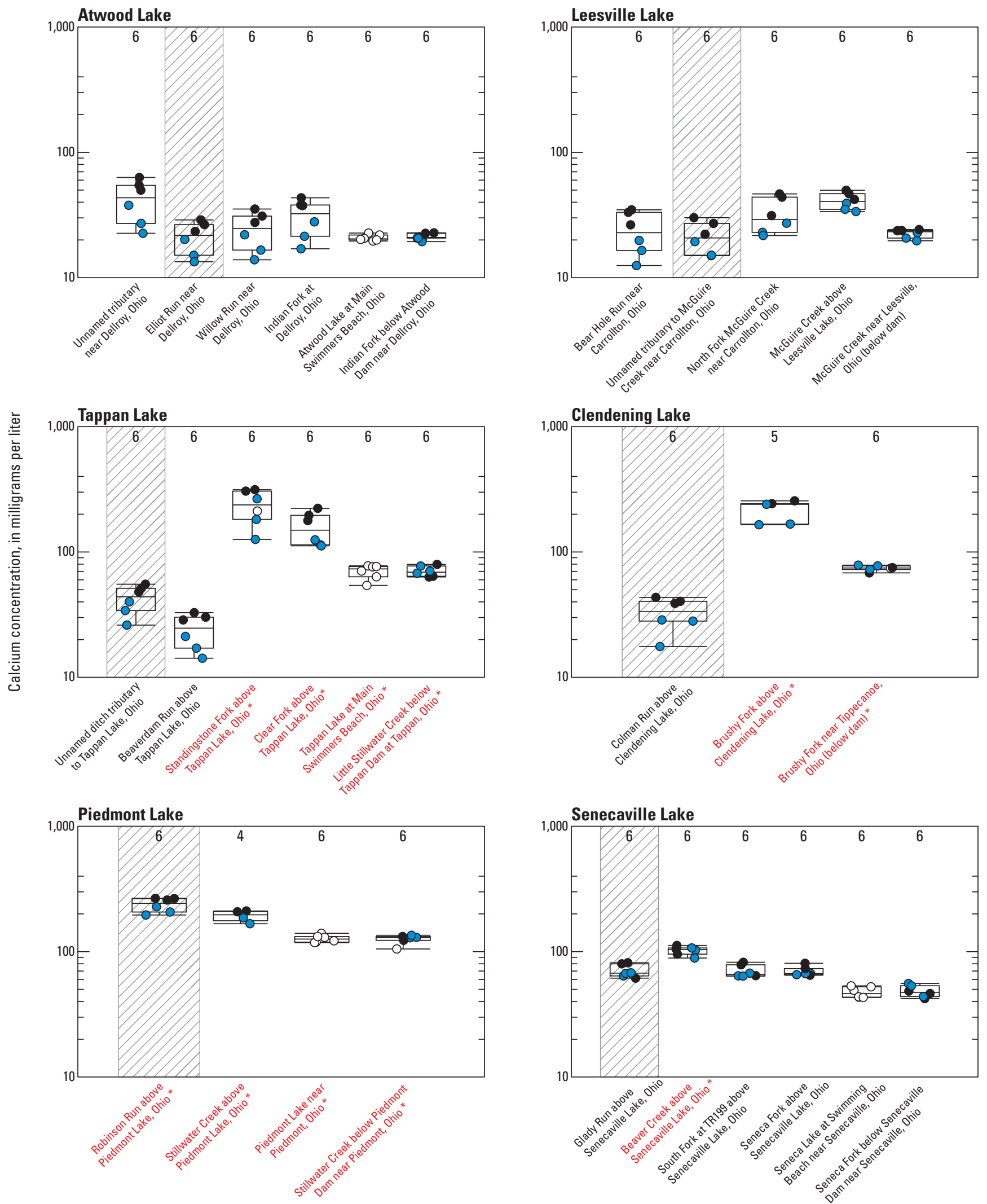

Sites ordered, left to right, from smallest to largest drainage area

Figure 2.12. Calcium concentrations at 30 sites in the Muskingum River watershed, Ohio, 2015-16. The sampling sites for each lake are arranged left-to-right in the order of increasing drainage area. Site names followed by an asterisk (*) and in red font are classified as mine-impacted sites. A diagonal-lined background indicates a reference site (site with no upstream shale-gas development). When applicable, the reporting level has been displayed as a dashed black line across the boxplots and censored values beneath this line have not been shown. 

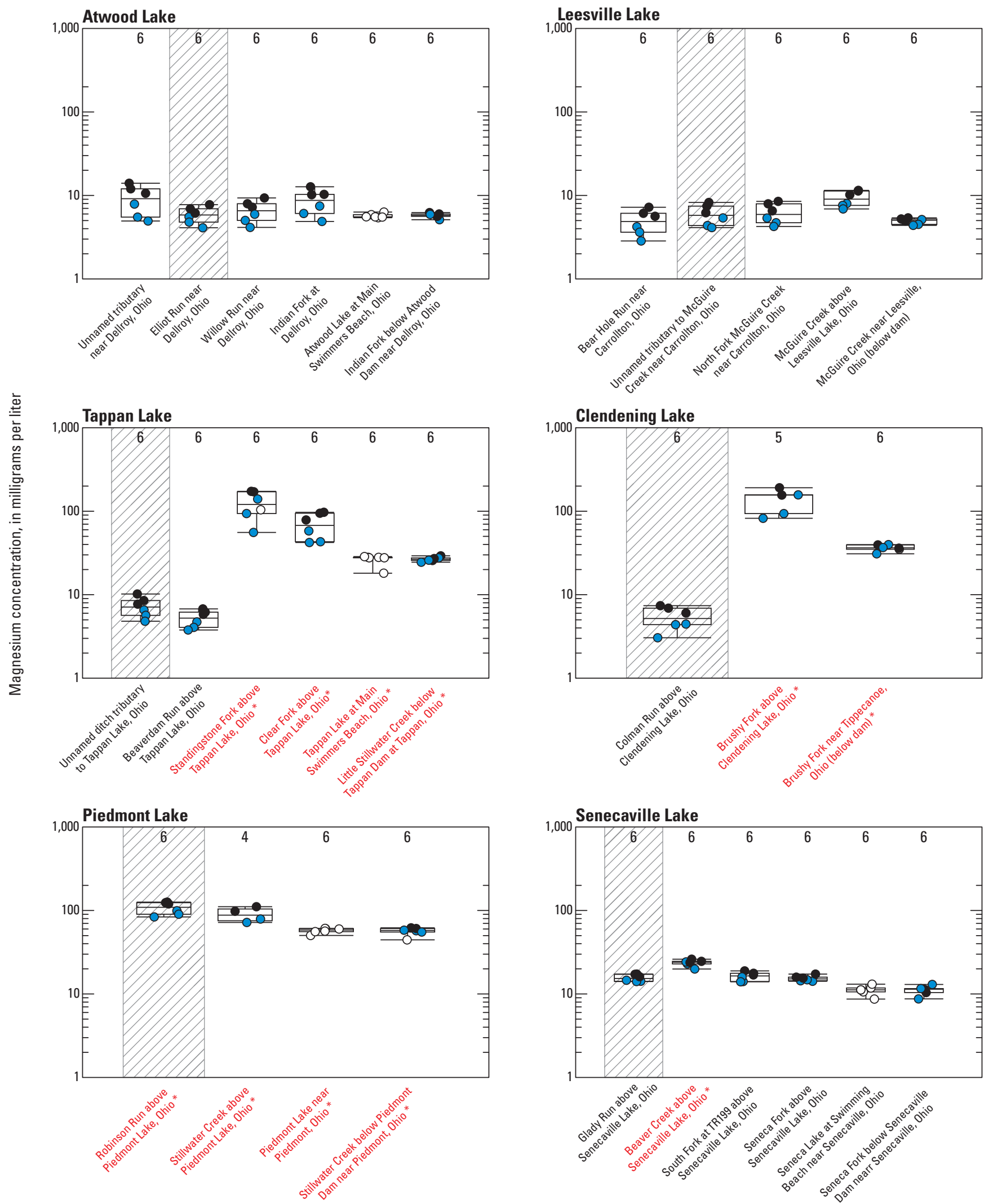

Sites ordered, left to right, from smallest to largest drainage area

Figure 2.13. Magnesium concentrations at 30 sites in the Muskingum River watershed, Ohio, 2015-16. The sampling sites for each lake are arranged left-to-right in the order of increasing drainage area. Site names followed by an asterisk $\left({ }^{*}\right)$ and in red font are classified as mine-impacted sites. A diagonal-lined background indicates a reference site (site with no upstream shale-gas development). When applicable, the reporting level has been displayed as a dashed black line across the boxplots and censored values beneath this line have not been shown. 

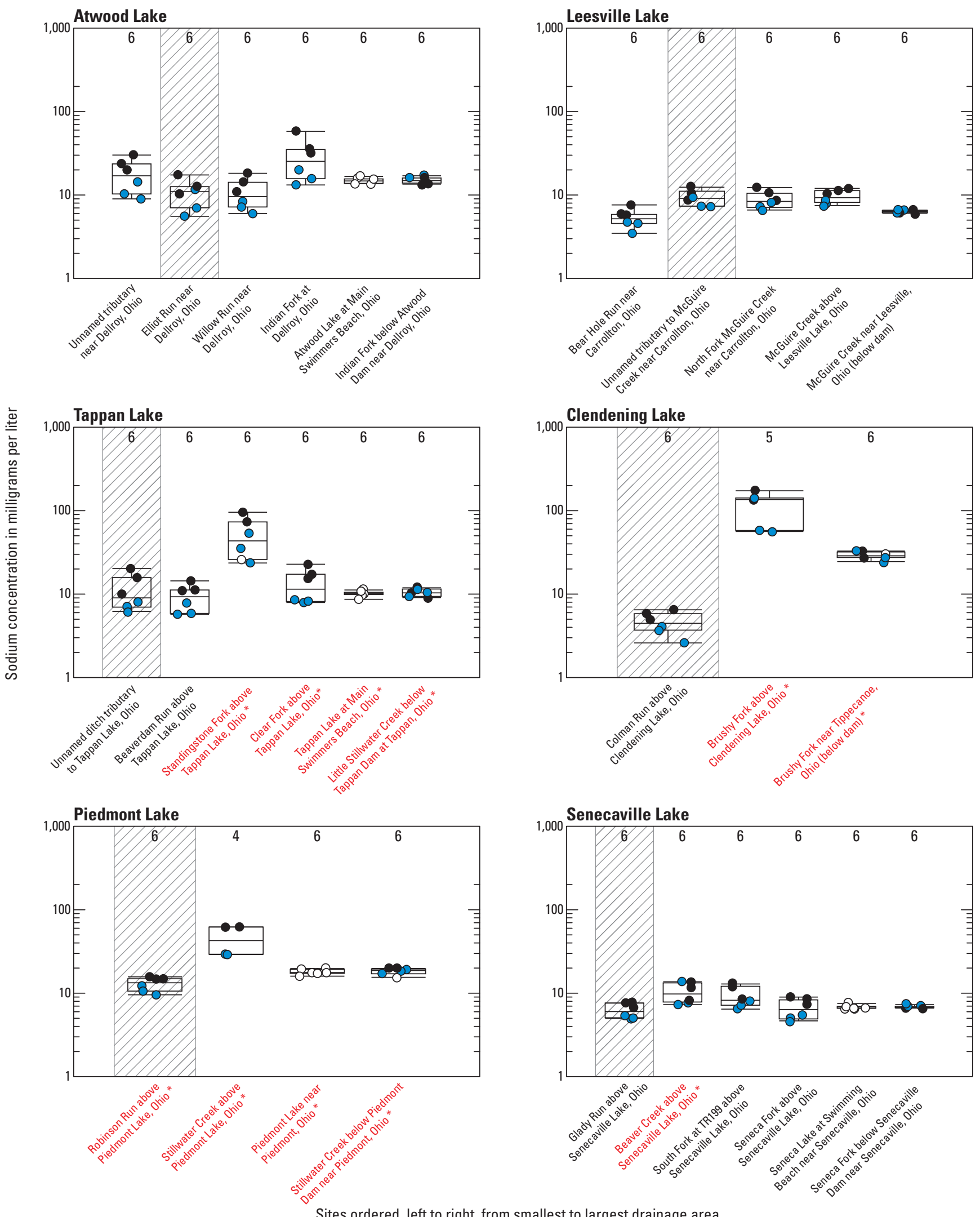

Figure 2.14. Sodium concentrations at 30 sites in the Muskingum River watershed, Ohio, 2015-16. The sampling sites for each lake are arranged left-to-right in the order of increasing drainage area. Site names followed by an asterisk $\left({ }^{*}\right)$ and in red font are classified as mine-impacted sites. A diagonal-lined background indicates a reference site (site with no upstream shale-gas development). When applicable, the reporting level has been displayed as a dashed black line across the boxplots and censored values beneath this line have not been shown. 

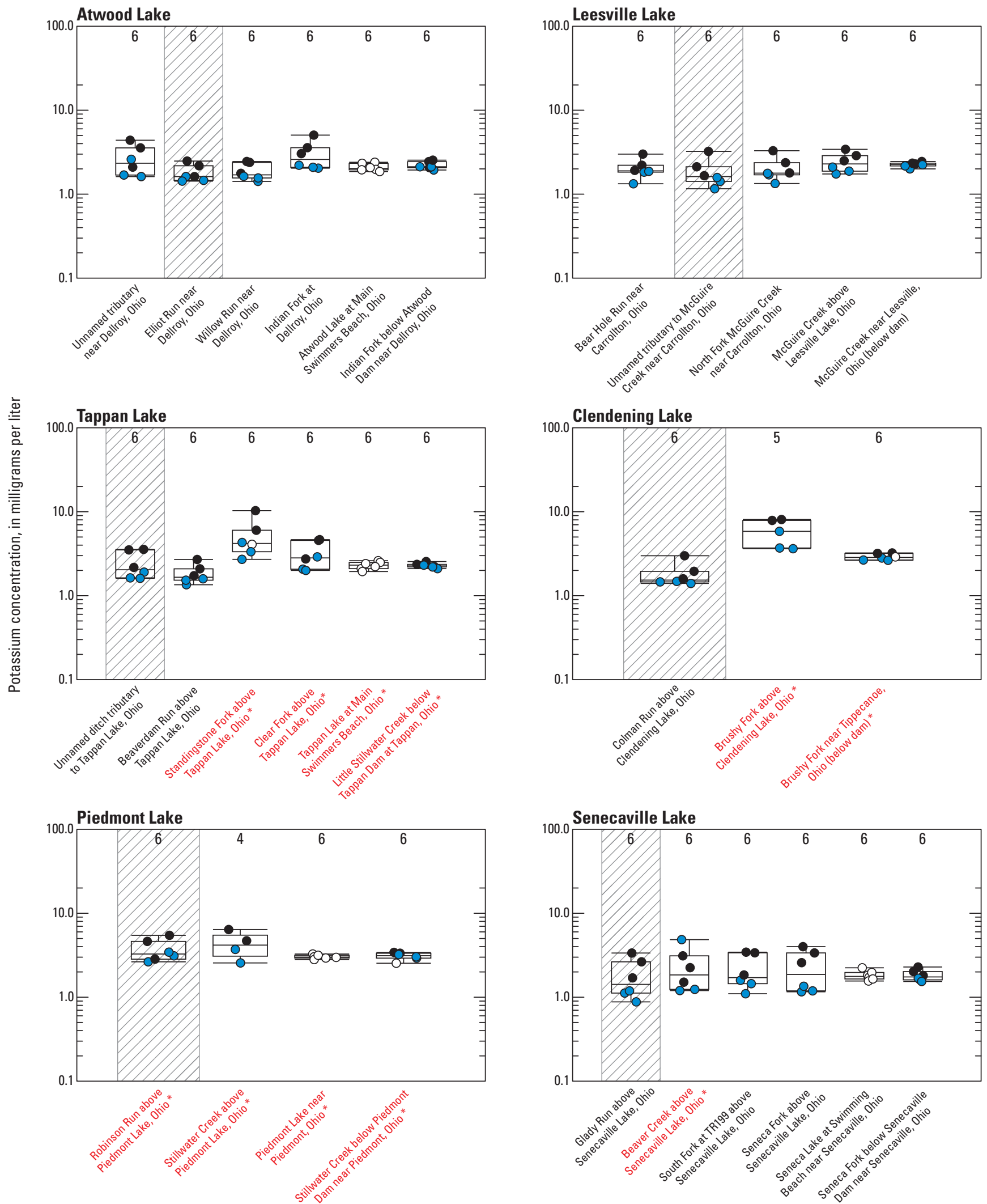

Sites ordered, left to right, from smallest to largest drainage area

Figure 2.15. Potassium concentrations at 30 sites in the Muskingum River watershed, Ohio, 2015-16. The sampling sites for each lake are arranged left-to-right in the order of increasing drainage area. Site names followed by an asterisk $\left({ }^{*}\right)$ and in red font are classified as mine-impacted sites. A diagonal-lined background indicates a reference site (site with no upstream shale-gas development). When applicable, the reporting level has been displayed as a dashed black line across the boxplots and censored values beneath this line have not been shown. 

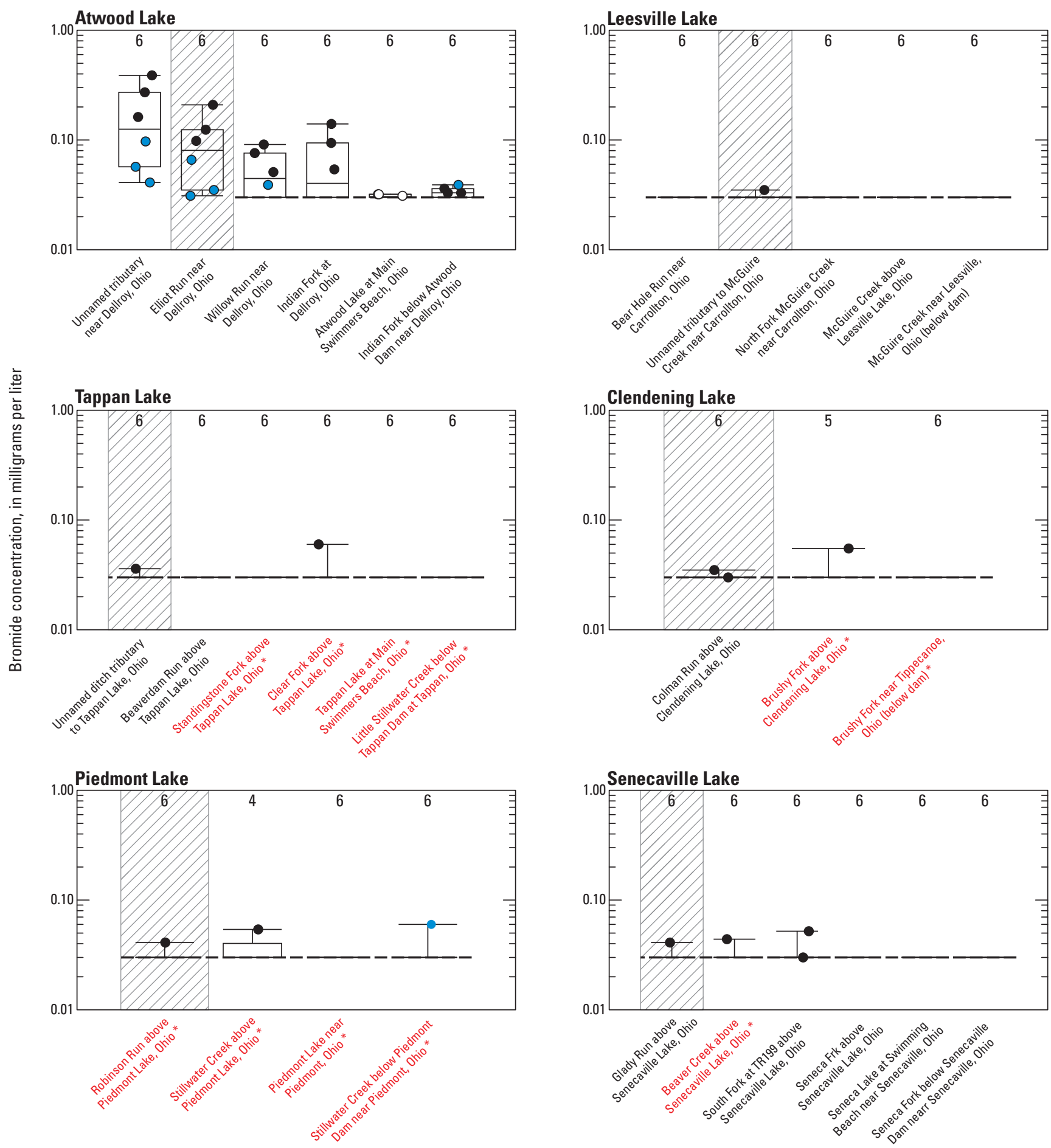

Sites ordered, left to right, from smallest to largest drainage area

Figure 2.16. Bromide concentrations at 30 sites in the Muskingum River watershed, Ohio, 2015-16. The sampling sites for each lake are arranged left-to-right in the order of increasing drainage area. Site names followed by an asterisk $\left({ }^{*}\right)$ and in red font are classified as mine-impacted sites. A diagonal-lined background indicates a reference site (site with no upstream shale-gas development). When applicable, the reporting level has been displayed as a dashed black line across the boxplots and censored values beneath this line have not been shown. 

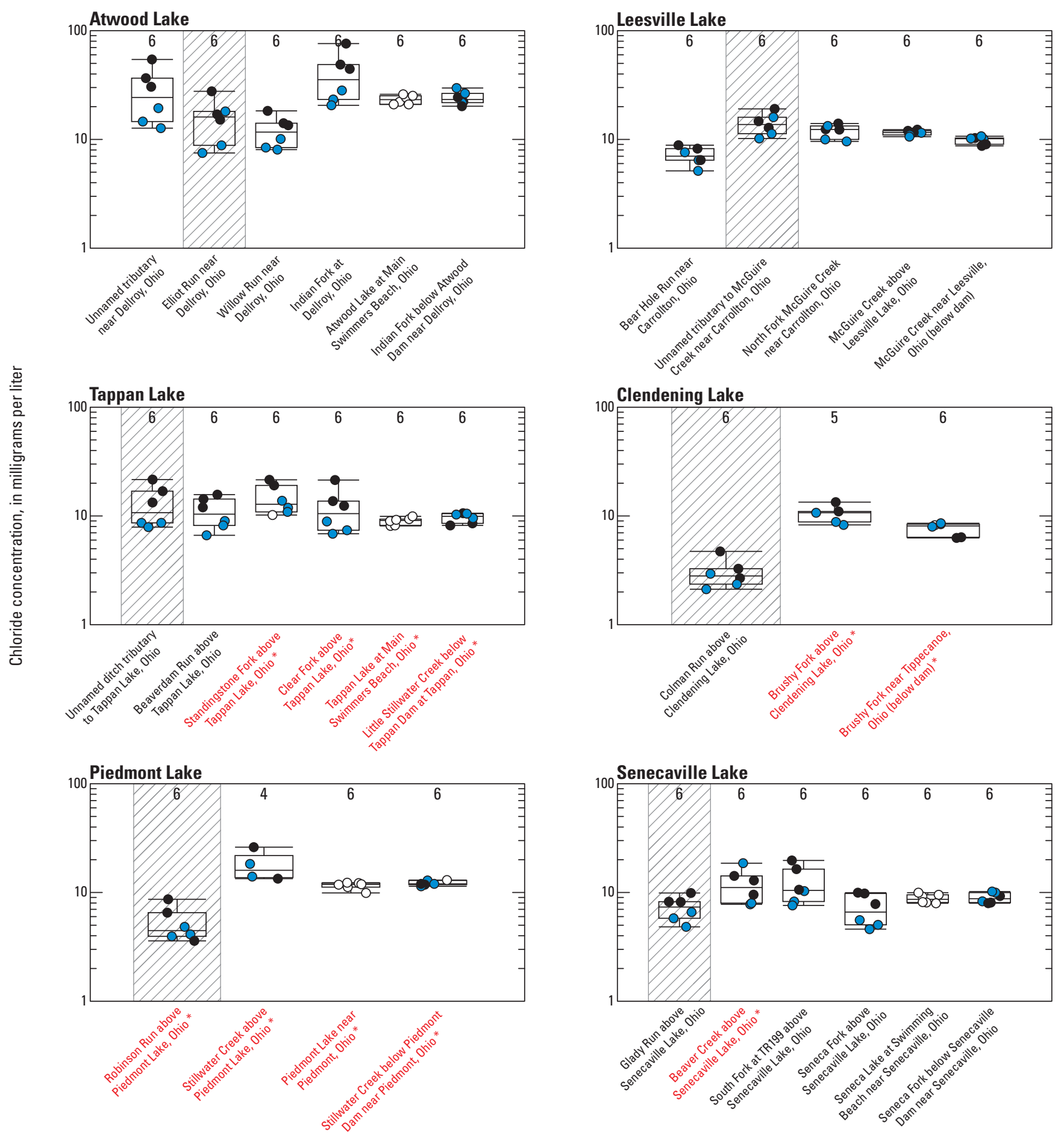

Sites ordered, left to right, from smallest to largest drainage area

Figure 2.17. Chloride concentrations at 30 sites in the Muskingum River watershed, 0 hio, 2015-16. The sampling sites for each lake are arranged left-to-right in the order of increasing drainage area. Site names followed by an asterisk (*) and in red font are classified as mine-impacted sites. A diagonal-lined background indicates a reference site (site with no upstream shale-gas development). When applicable, the reporting level has been displayed as a dashed black line across the boxplots and censored values beneath this line have not been shown. 

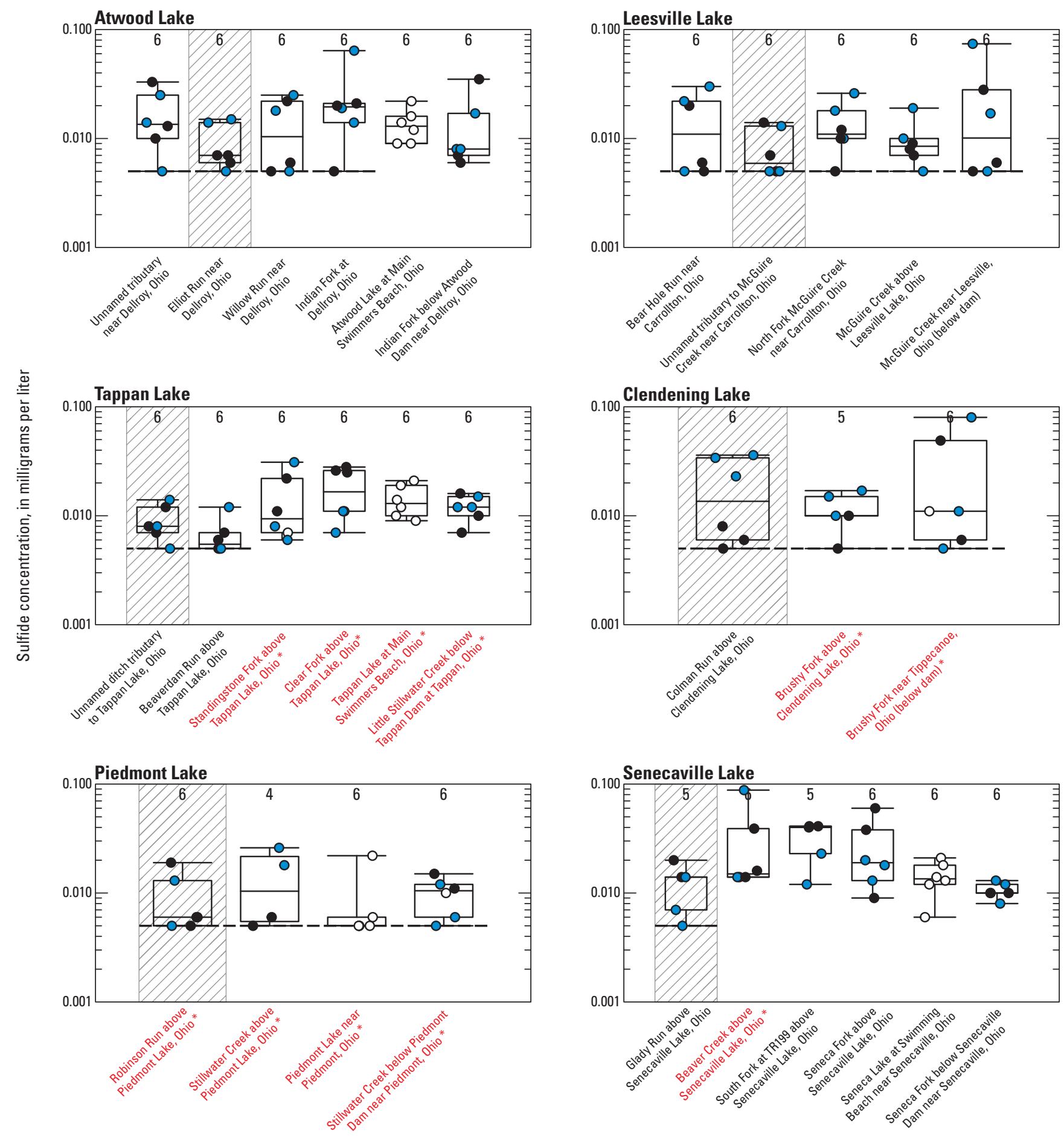

Sites ordered, left to right, from smallest to largest drainage area

Figure 2.18. Sulfide concentrations at 30 sites in the Muskingum River watershed, Ohio, 2015-16. The sampling sites for each lake are arranged left-to-right in the order of increasing drainage area. Site names followed by an asterisk (*) and in red font are classified as mine-impacted sites. A diagonal-lined background indicates a reference site (site with no upstream shale-gas development). When applicable, the reporting level has been displayed as a dashed black line across the boxplots and censored values beneath this line have not been shown. 

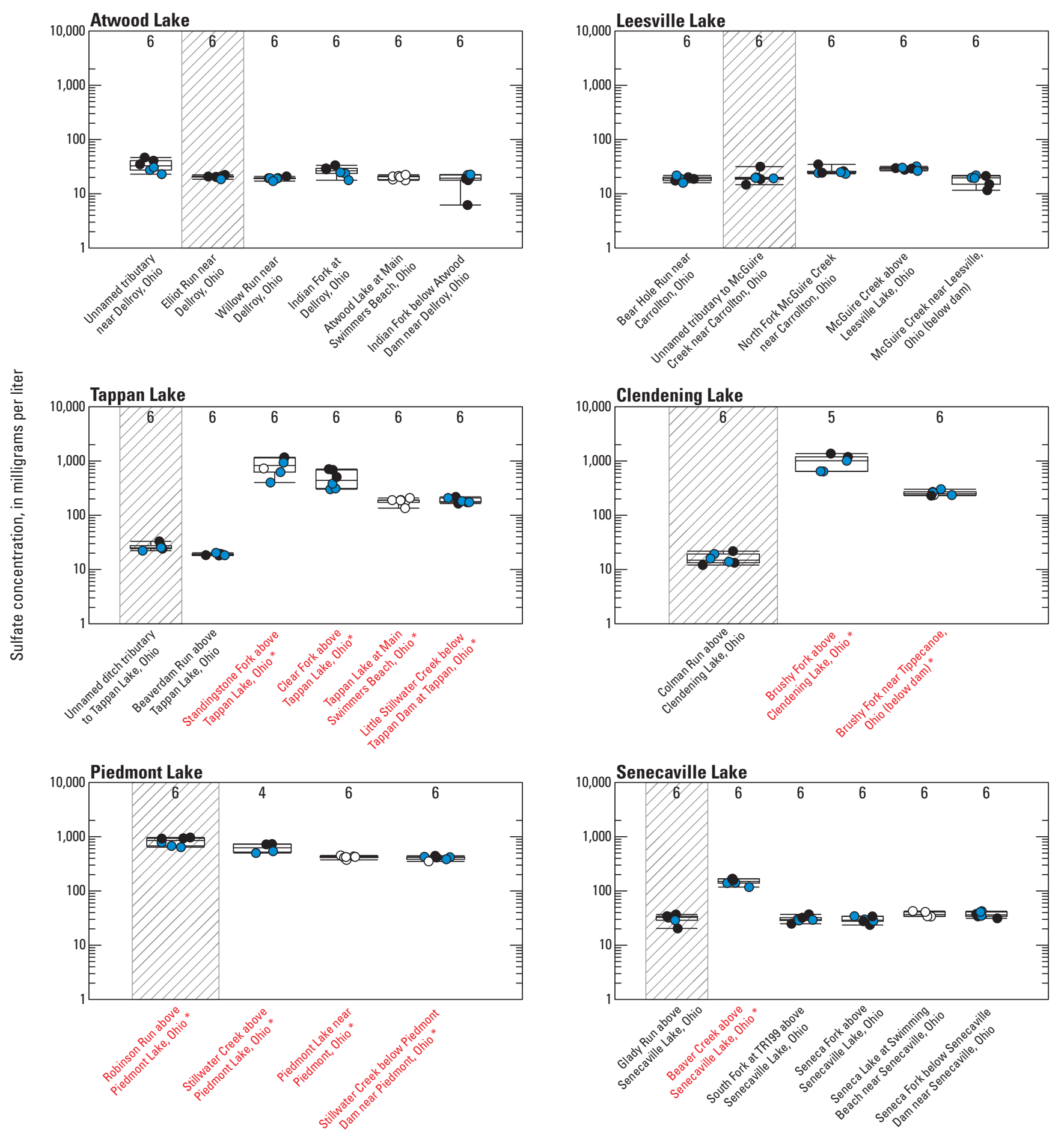

Sites ordered, left to right, from smallest to largest drainage area

Figure 2.19. Sulfate concentrations at 30 sites in the Muskingum River watershed, 0 hio, 2015-16. The sampling sites for each lake are arranged left-to-right in the order of increasing drainage area. Site names followed by an asterisk $\left({ }^{*}\right)$ and in red font are classified as mine-impacted sites. A diagonal-lined background indicates a reference site (site with no upstream shale-gas development). When applicable, the reporting level has been displayed as a dashed black line across the boxplots and censored values beneath this line have not been shown. 

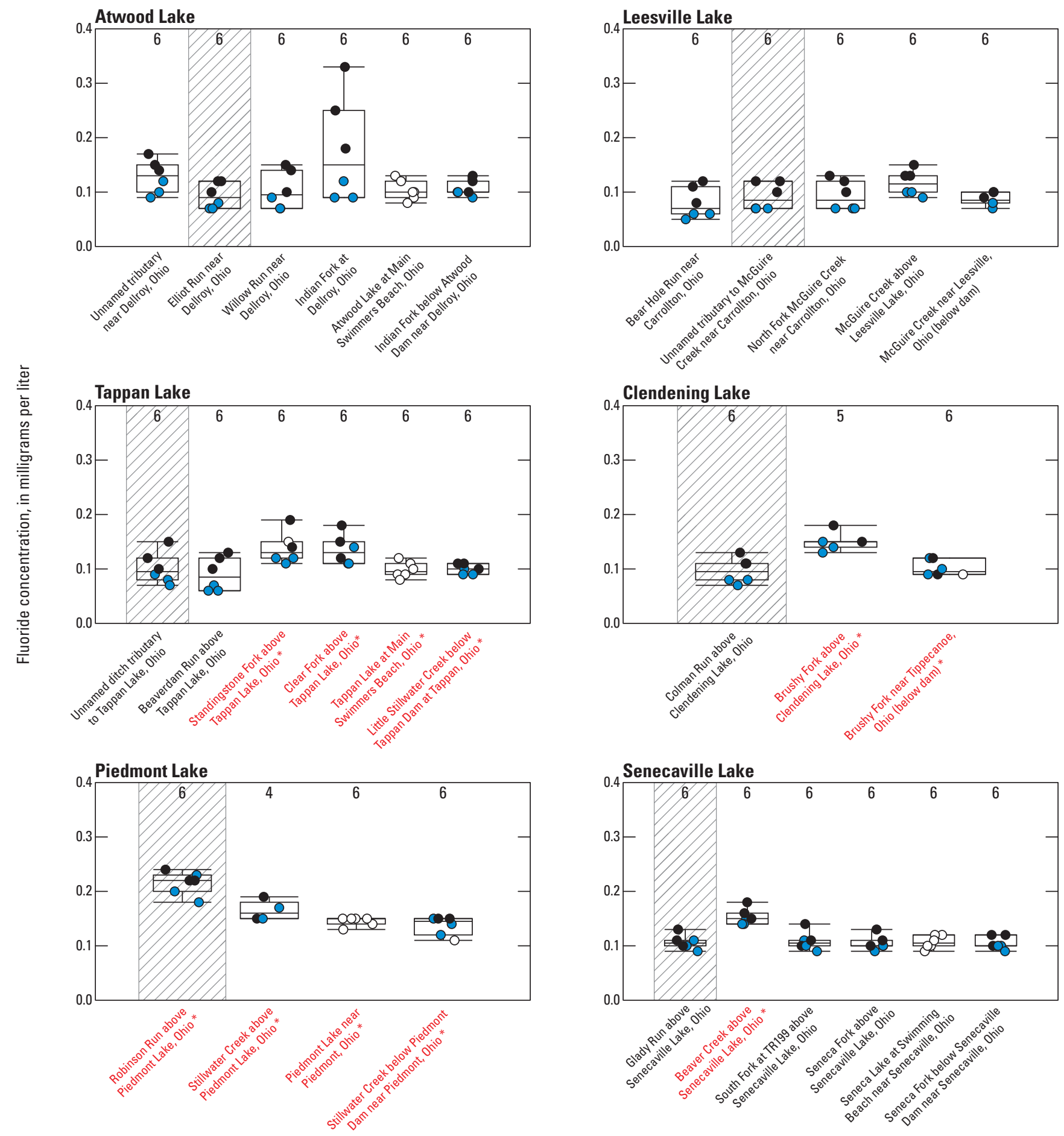

Sites ordered, left to right, from smallest to largest drainage area

Figure 2.20. Fluoride concentrations at 30 sites in the Muskingum River watershed, 0 hio, 2015-16. The sampling sites for each lake are arranged left-to-right in the order of increasing drainage area. Site names followed by an asterisk (*) and in red font are classified as mine-impacted sites. A diagonal-lined background indicates a reference site (site with no upstream shale-gas development). When applicable, the reporting level has been displayed as a dashed black line across the boxplots and censored values beneath this line have not been shown. 

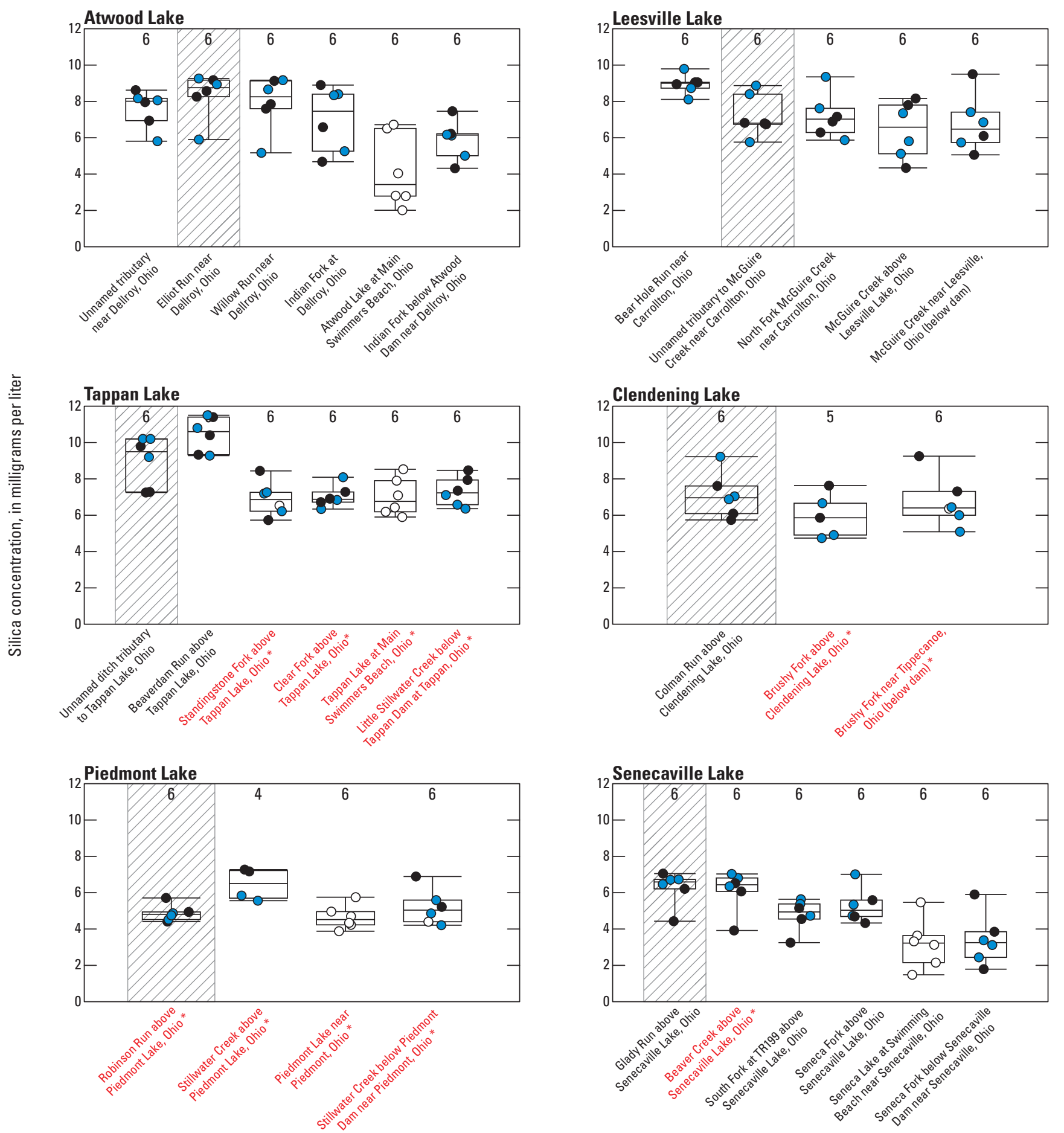

Sites ordered, left to right, from smallest to largest drainage area

Figure 2.21. Silica concentrations at 30 sites in the Muskingum River watershed, Ohio, 2015-16. The sampling sites for each lake are arranged left-to-right in the order of increasing drainage area. Site names followed by an asterisk (*) and in red font are classified as mine-impacted sites. A diagonal-lined background indicates a reference site (site with no upstream shale-gas development). When applicable, the reporting level has been displayed as a dashed black line across the boxplots and censored values beneath this line have not been shown. 

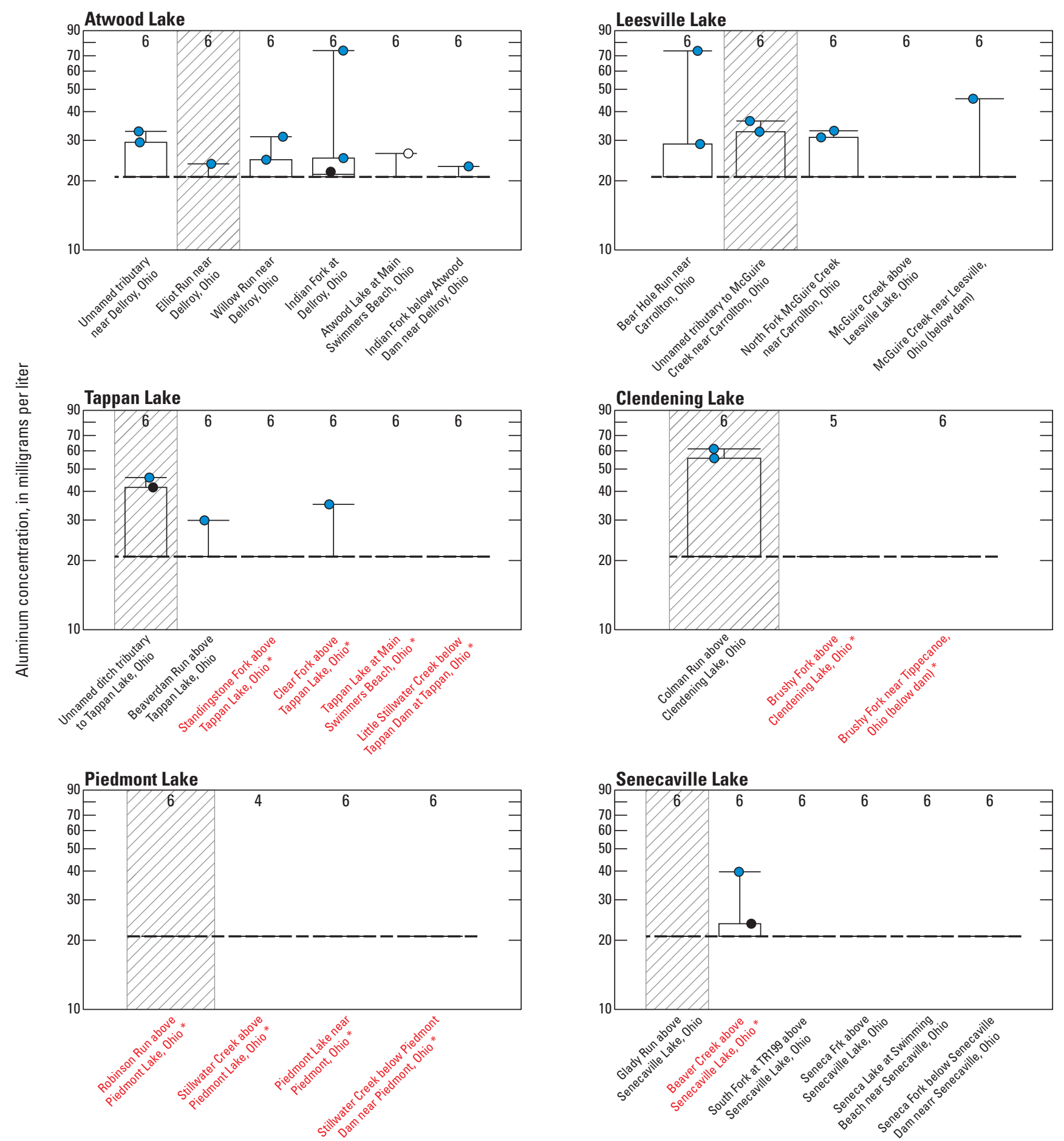

Sites ordered, left to right, from smallest to largest drainage area

Figure 2.22. Aluminum concentrations at 30 sites in the Muskingum River watershed, Ohio, 2015-16. The sampling sites for each lake are arranged left-to-right in the order of increasing drainage area. Site names followed by an asterisk (*) and in red font are classified as mine-impacted sites. A diagonal-lined background indicates a reference site (site with no upstream shale-gas development). When applicable, the reporting level has been displayed as a dashed black line across the boxplots and censored values beneath this line have not been shown. 

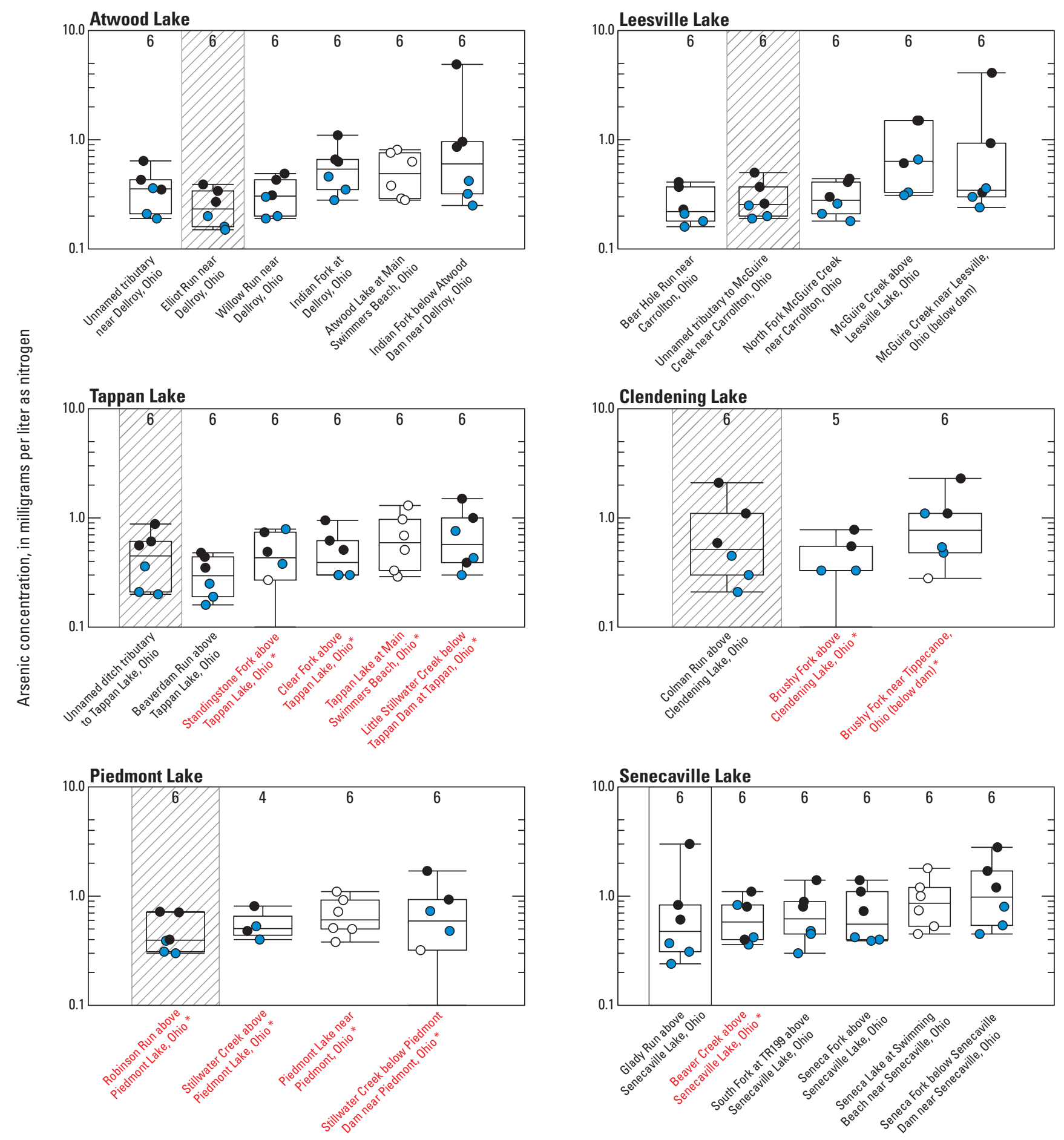

Sites ordered, left to right, from smallest to largest drainage area

Figure 2.23. Arsenic concentrations at 30 sites in the Muskingum River watershed, Ohio, 2015-16. The sampling sites for each lake are arranged left-to-right in the order of increasing drainage area. Site names followed by an asterisk $\left({ }^{*}\right)$ and in red font are classified as mine-impacted sites. A diagonal-lined background indicates a reference site (site with no upstream shale-gas development). When applicable, the reporting level has been displayed as a dashed black line across the boxplots and censored values beneath this line have not been shown. 

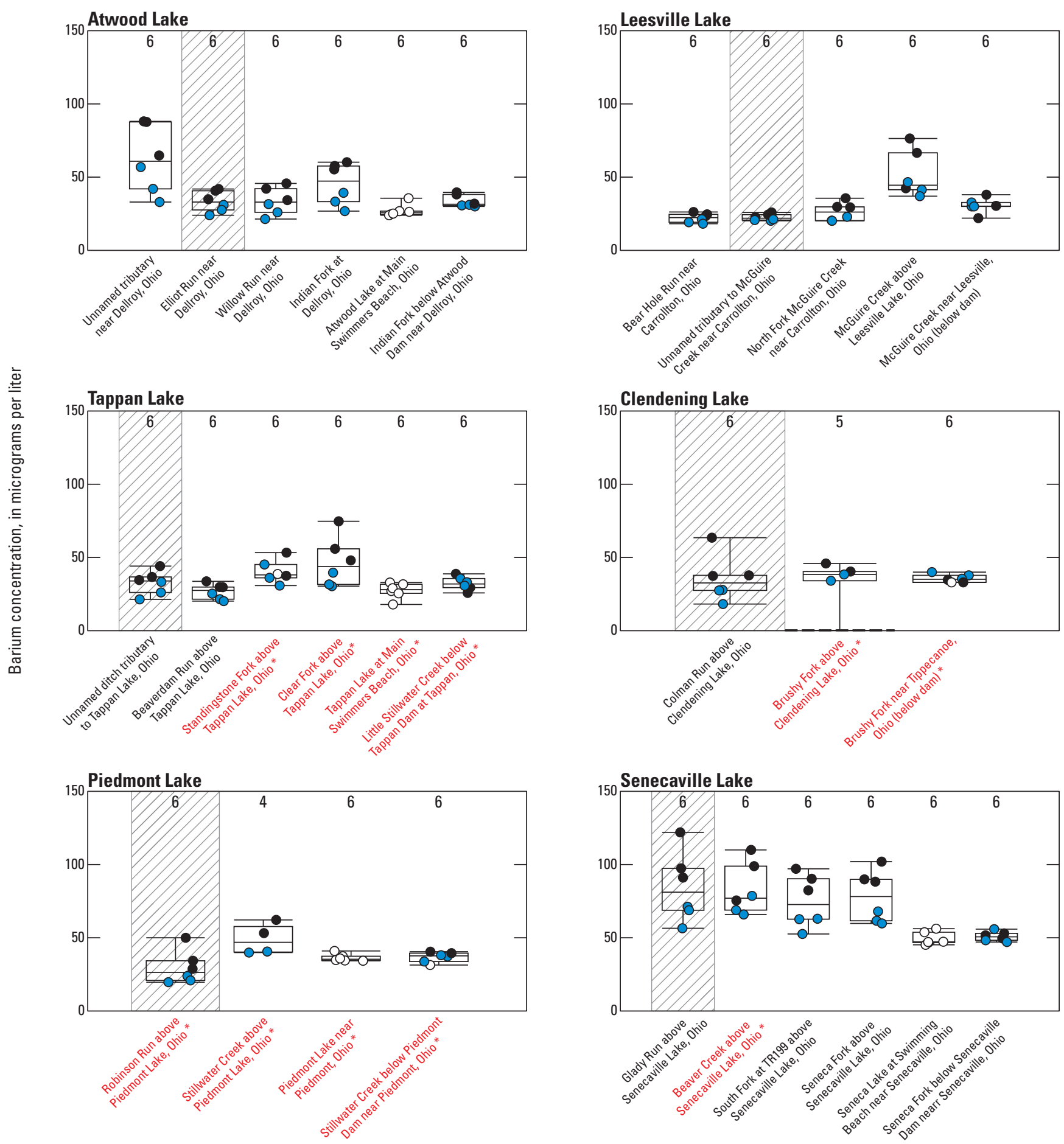

Sites ordered, left to right, from smallest to largest drainage area

Figure 2.24. Barium concentrations at 30 sites in the Muskingum River watershed, Ohio, 2015-16. The sampling sites for each lake are arranged left-to-right in the order of increasing drainage area. Site names followed by an asterisk (*) and in red font are classified as mine-impacted sites. A diagonal-lined background indicates a reference site (site with no upstream shale-gas development). When applicable, the reporting level has been displayed as a dashed black line across the boxplots and censored values beneath this line have not been shown. 

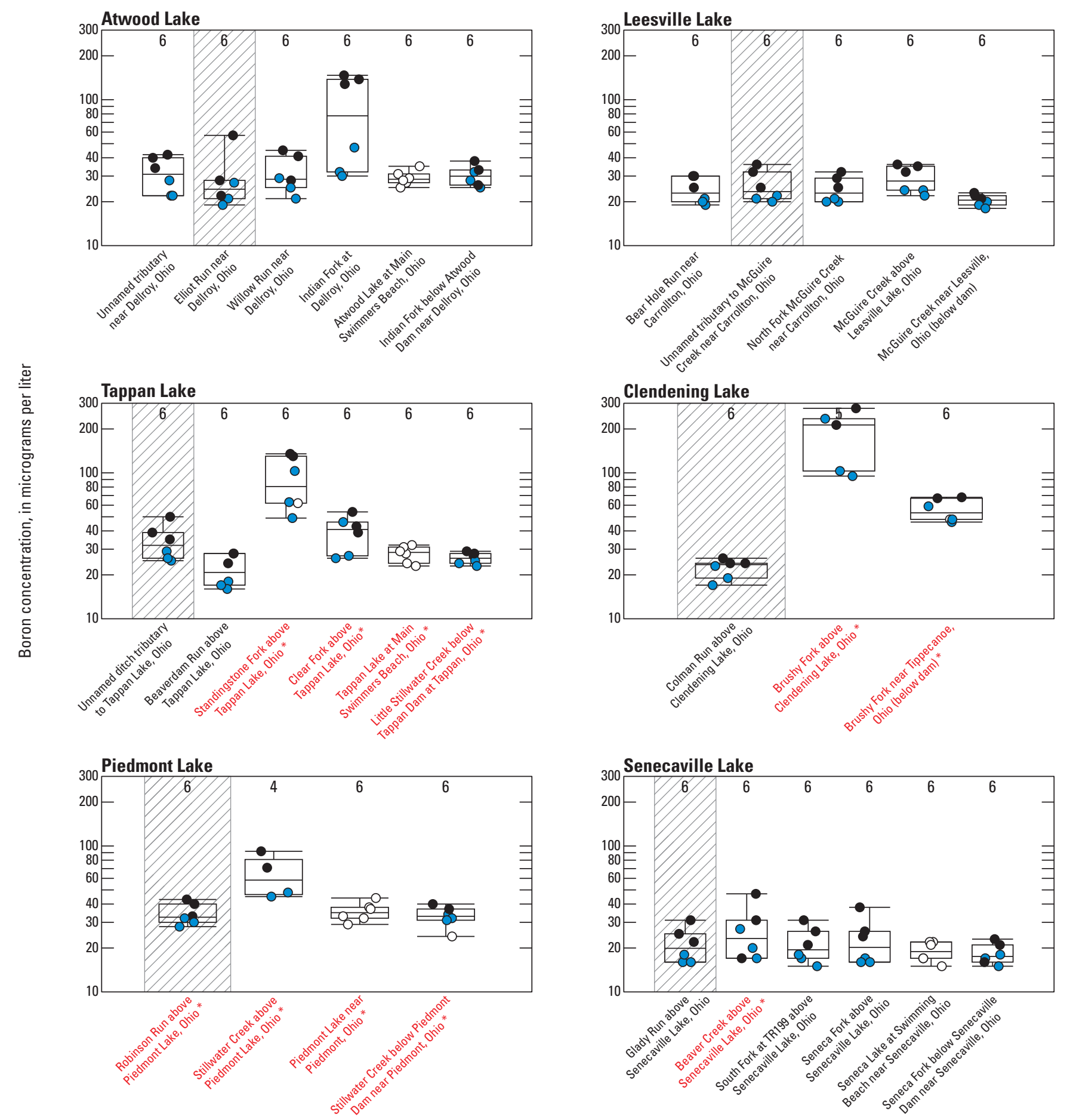

Sites ordered, left to right, from smallest to largest drainage area

Figure 2.25. Boron concentrations at 30 sites in the Muskingum River watershed, Ohio, 2015-16. The sampling sites for each lake are arranged left-to-right in the order of increasing drainage area. Site names followed by an asterisk $\left({ }^{*}\right)$ and in red font are classified as mine-impacted sites. A diagonal-lined background indicates a reference site (site with no upstream shale-gas development). When applicable, the reporting level has been displayed as a dashed black line across the boxplots and censored values beneath this line have not been shown. 

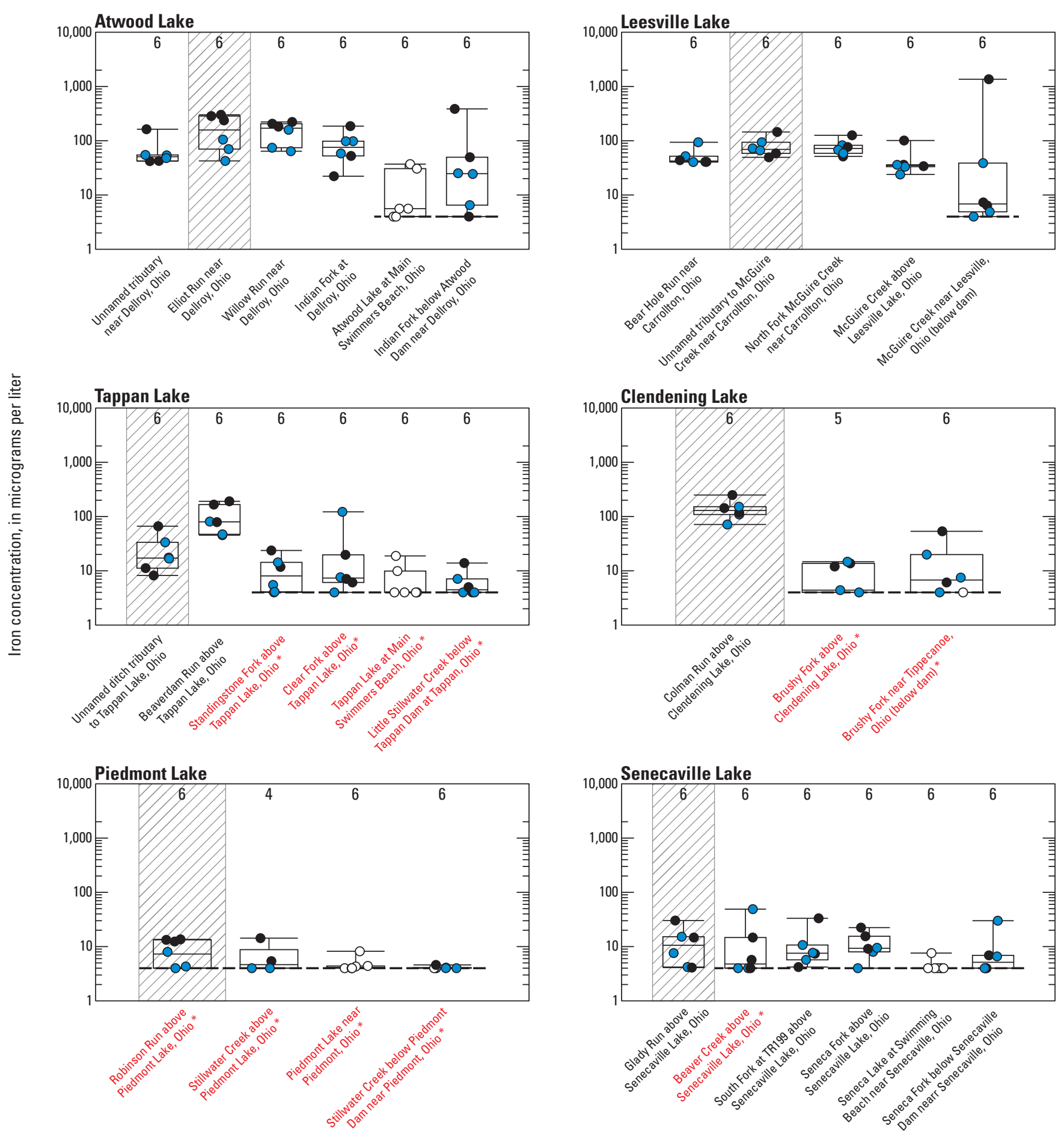

Sites ordered, left to right, from smallest to largest drainage area

Figure 2.26. Iron concentrations at 30 sites in the Muskingum River watershed, 0 hio, 2015-16. The sampling sites for each lake are arranged left-to-right in the order of increasing drainage area. Site names followed by an asterisk $\left(^{*}\right)$ and in red font are classified as mine-impacted sites. A diagonal-lined background indicates a reference site (site with no upstream shale-gas development). When applicable, the reporting level has been displayed as a dashed black line across the boxplots and censored values beneath this line have not been shown. 

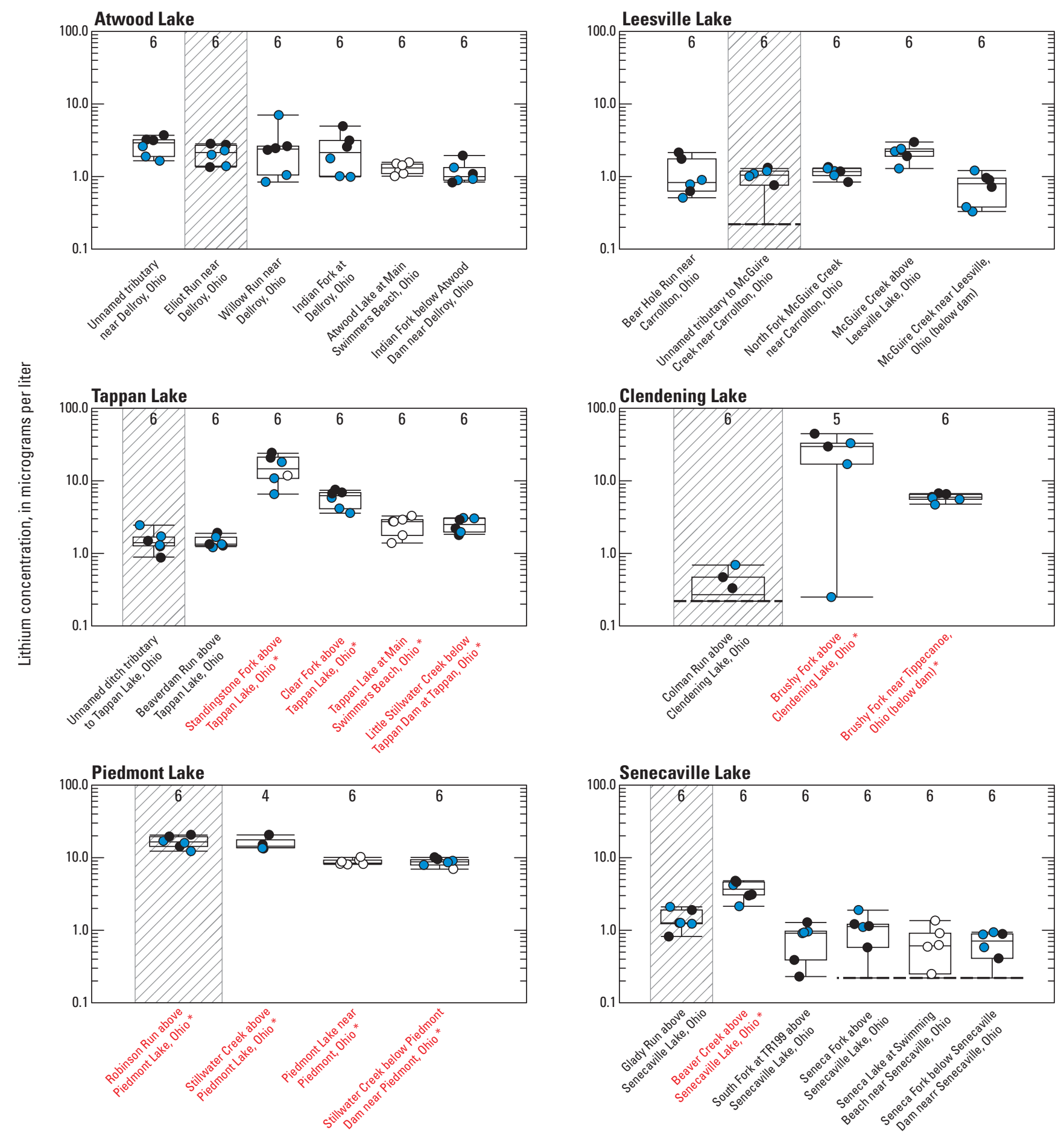

Sites ordered, left to right, from smallest to largest drainage area

Figure 2.27. Lithium concentrations at 30 sites in the Muskingum River watershed, 0hio, 2015-16. The sampling sites for each lake are arranged left-to-right in the order of increasing drainage area. Site names followed by an asterisk $\left({ }^{*}\right)$ and in red font are classified as mine-impacted sites. A diagonal-lined background indicates a reference site (site with no upstream shale-gas development). When applicable, the reporting level has been displayed as a dashed black line across the boxplots and censored values beneath this line have not been shown. 

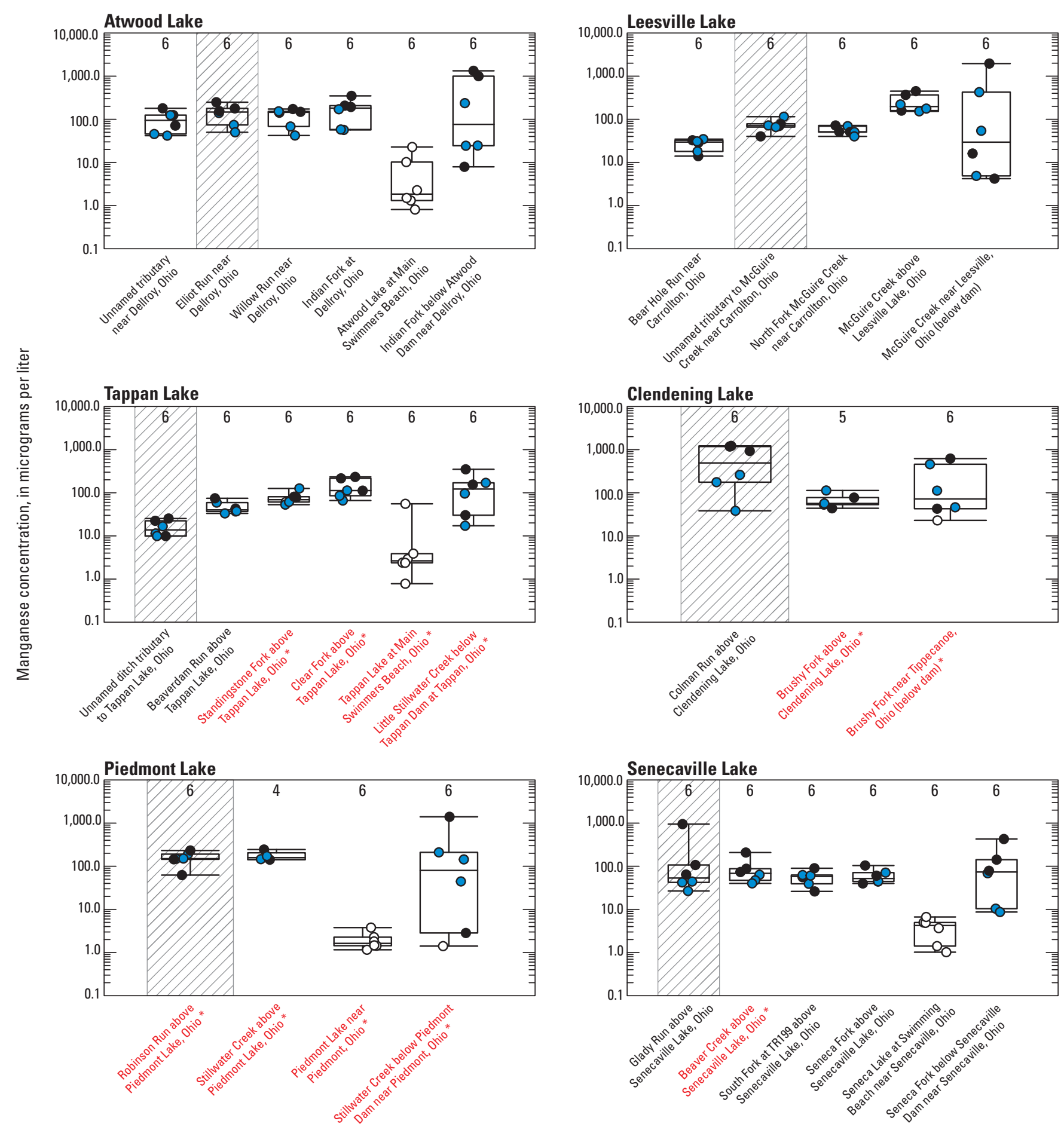

Sites ordered, left to right, from smallest to largest drainage area

Figure 2.28. Manganese concentrations at 30 sites in the Muskingum River watershed, Ohio, 2015-16. The sampling sites for each lake are arranged left-to-right in the order of increasing drainage area. Site names followed by an asterisk $\left({ }^{*}\right)$ and in red font are classified as mine-impacted sites. A diagonal-lined background indicates a reference site (site with no upstream shale-gas development). When applicable, the reporting level has been displayed as a dashed black line across the boxplots and censored values beneath this line have not been shown. 

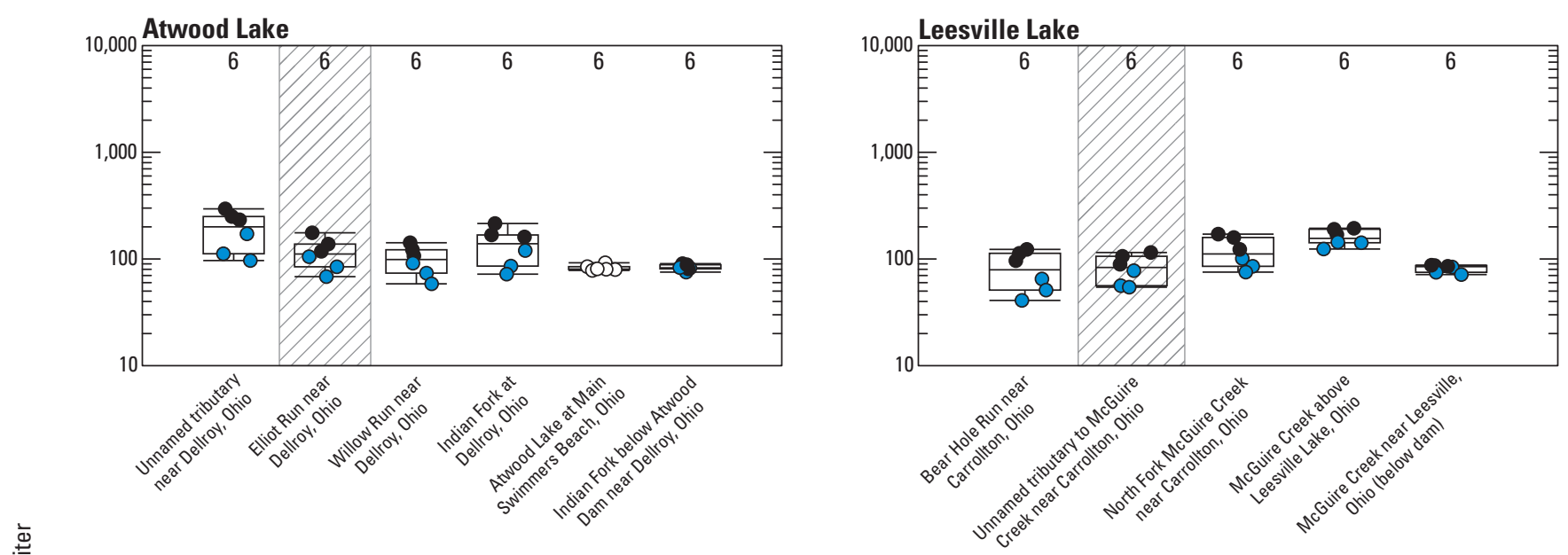

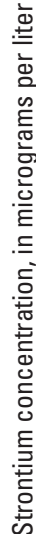
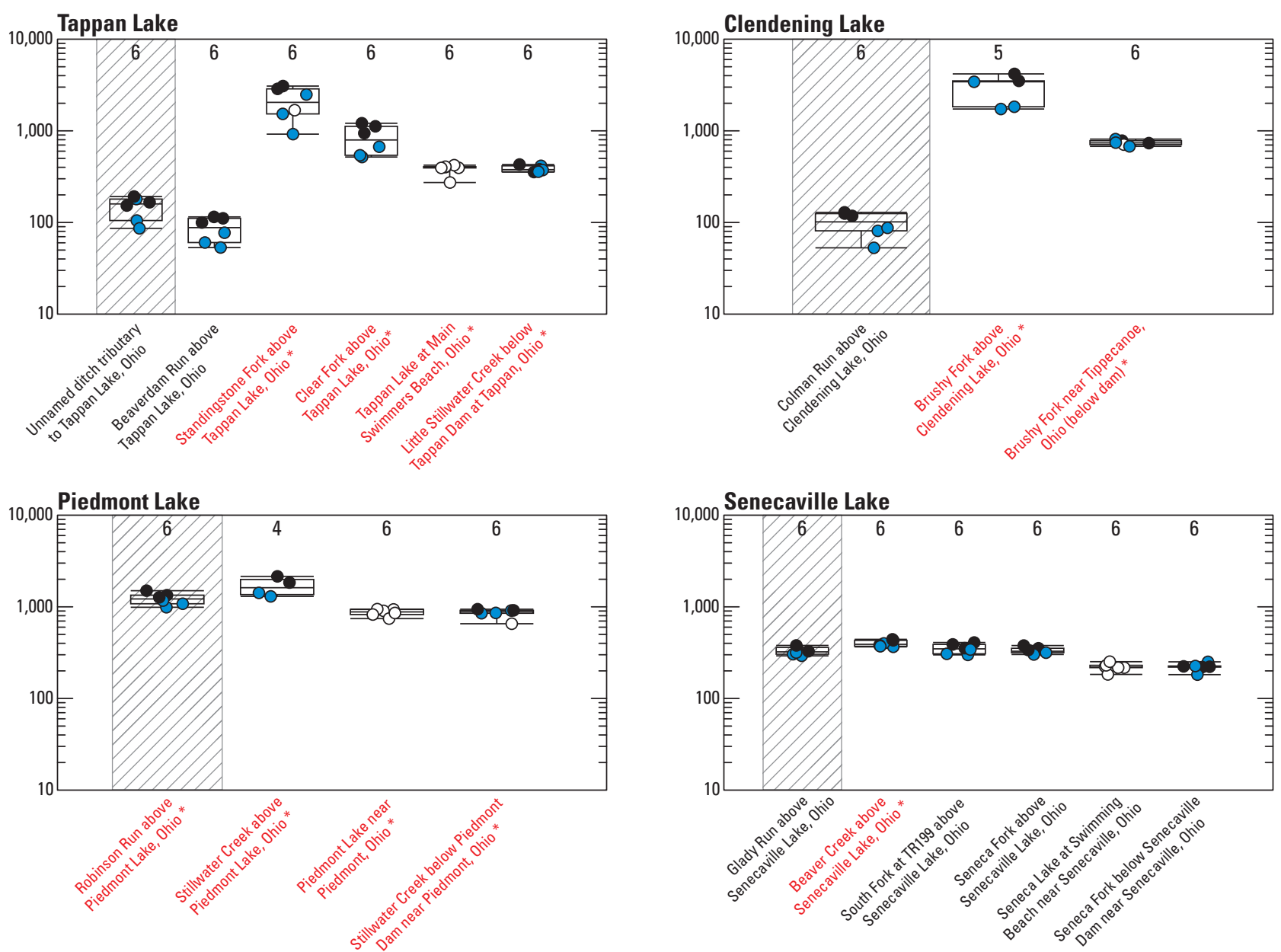

Sites ordered, left to right, from smallest to largest drainage area

Figure 2.29. Strontium concentrations at 30 sites in the Muskingum River watershed, Ohio, 2015-16. The sampling sites for each lake are arranged left-to-right in the order of increasing drainage area. Site names followed by an asterisk (*) and in red font are classified as mine-impacted sites. A diagonal-lined background indicates a reference site (site with no upstream shale-gas development).

When applicable, the reporting level has been displayed as a dashed black line across the boxplots and censored values beneath this line have not been shown. 

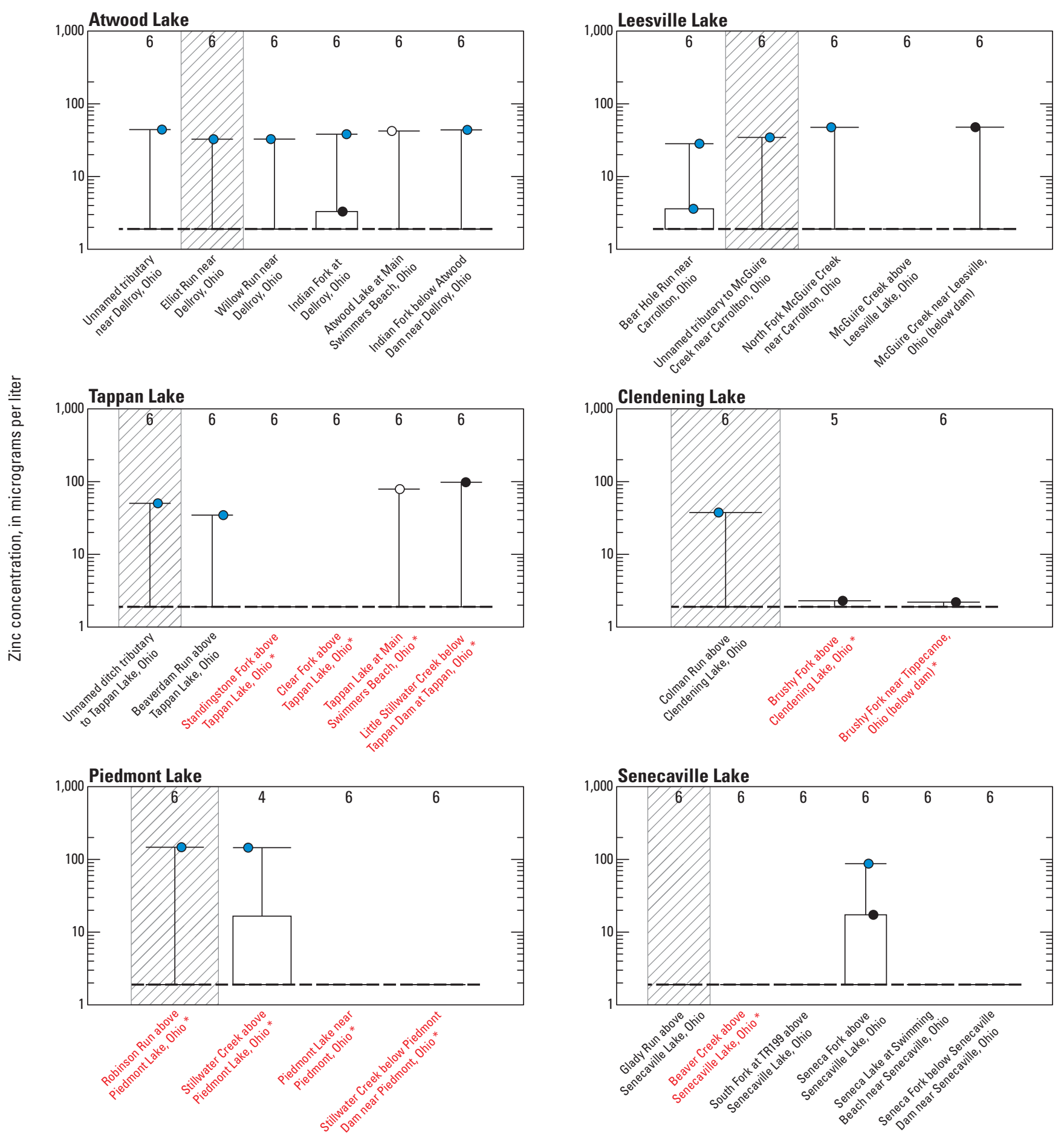

Sites ordered, left to right, from smallest to largest drainage area

Figure 2.30. Zinc concentrations at 30 sites in the Muskingum River watershed, Ohio, 2015-16. The sampling sites for each lake are arranged left-to-right in the order of increasing drainage area. Site names followed by an asterisk (*) and in red font are classified as mine-impacted sites. A diagonal-lined background indicates a reference site (site with no upstream shale-gas development). When applicable, the reporting level has been displayed as a dashed black line across the boxplots and censored values beneath this line have not been shown. 

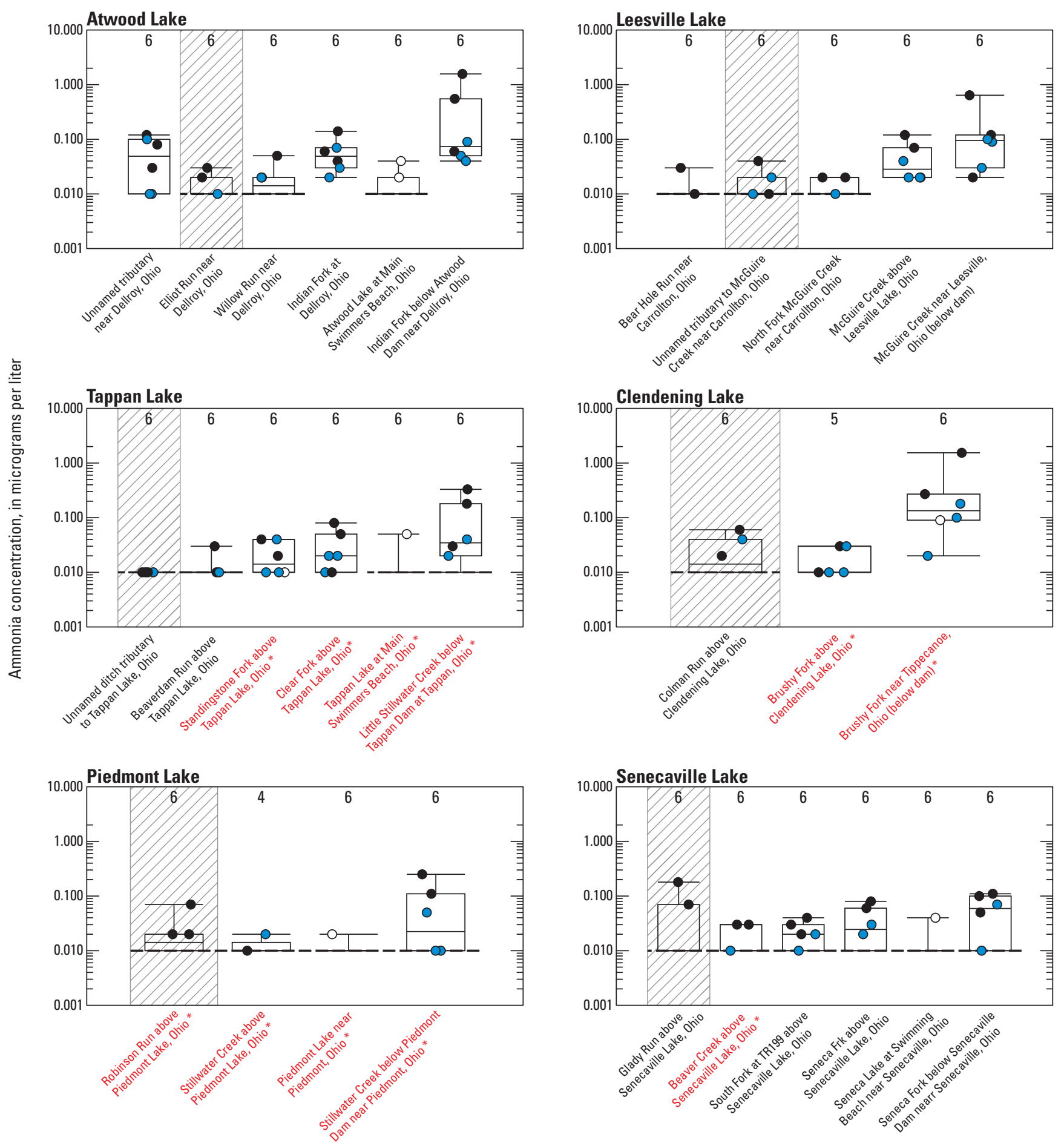

Sites ordered, left to right, from smallest to largest drainage area

Figure 2.31. Ammonia concentrations at 30 sites in the Muskingum River watershed, Ohio, 2015-16. The sampling sites for each lake are arranged left-to-right in the order of increasing drainage area. Site names followed by an asterisk (*) and in red font are classified as mine-impacted sites. A diagonal-lined background indicates a reference site (site with no upstream shale-gas development). When applicable, the reporting level has been displayed as a dashed black line across the boxplots and censored values beneath this line have not been shown. 

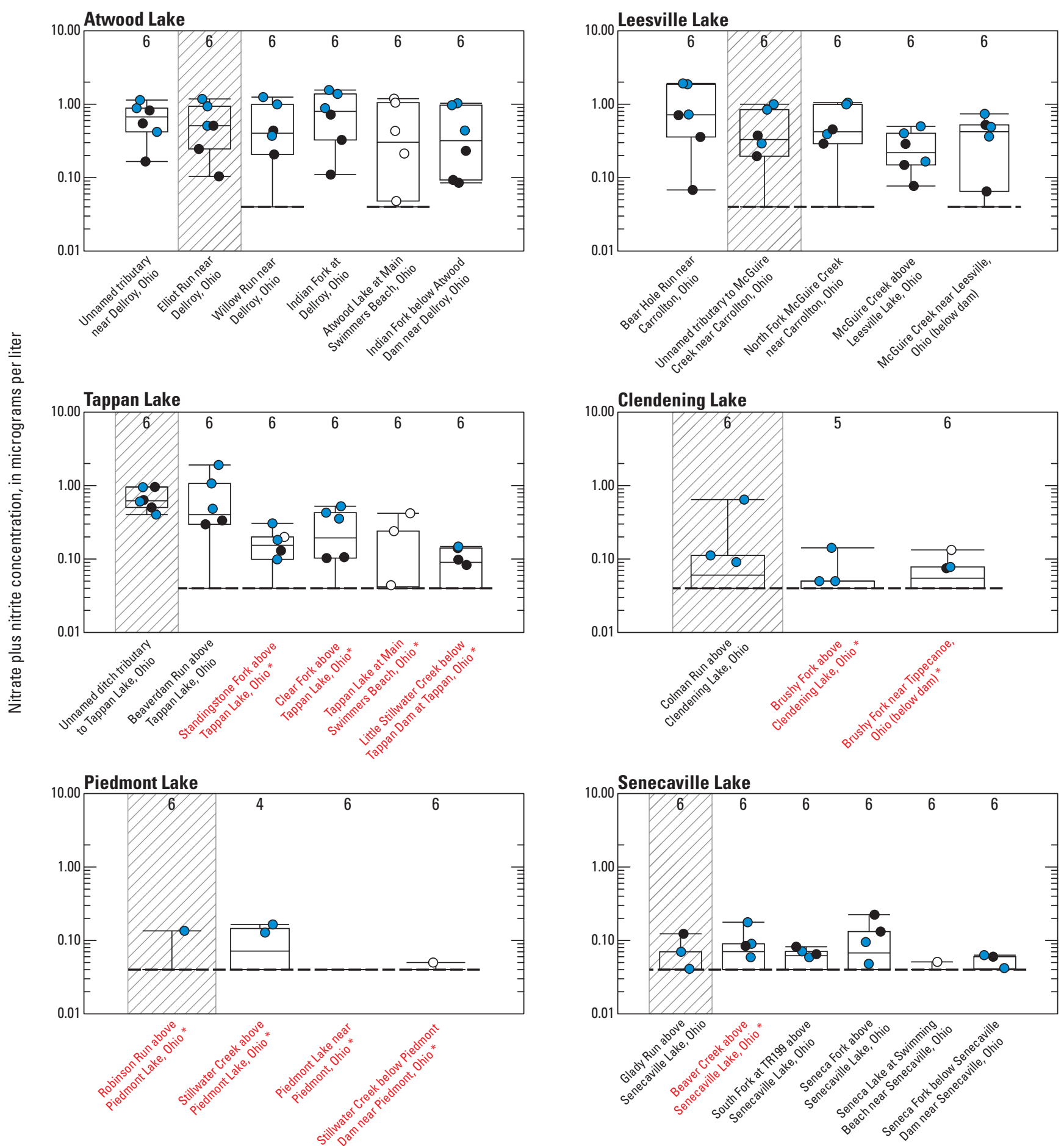

Sites ordered, left to right, from smallest to largest drainage area

Figure 2.32. Nitrate plus nitrite concentrations at 30 sites in the Muskingum River watershed, 0hio, 2015-16. The sampling sites for each lake are arranged left-to-right in the order of increasing drainage area. Site names followed by an asterisk $\left(^{*}\right.$ ) and in red font are classified as mine-impacted sites. A diagonal-lined background indicates a reference site (site with no upstream shale-gas development). When applicable, the reporting level has been displayed as a dashed black line across the boxplots and censored values beneath this line have not been shown. 

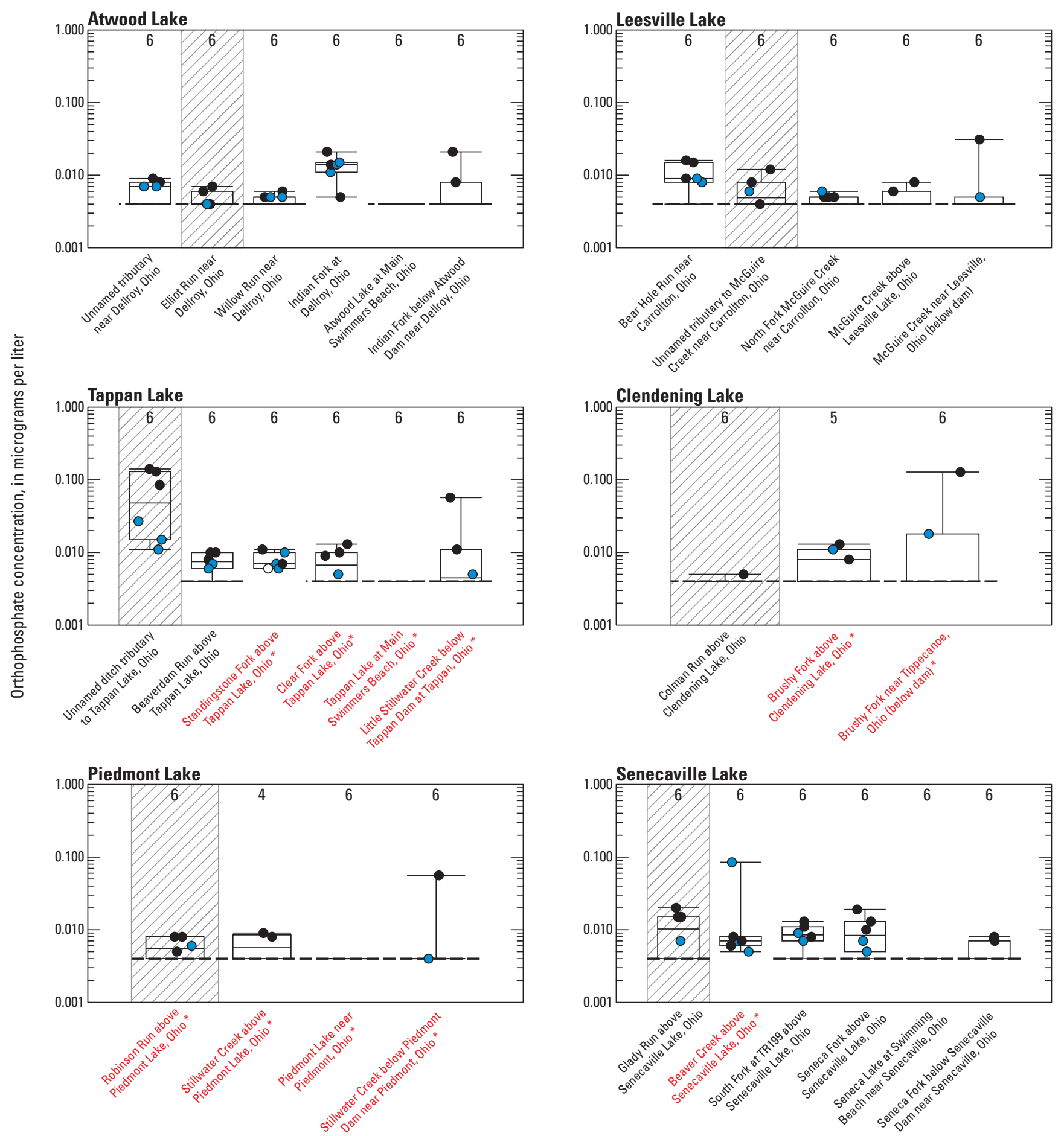

Sites ordered, left to right, from smallest to largest drainage area

Figure 2.33. Orthophosphate concentrations at 30 sites in the Muskingum River watershed, Ohio, 2015-16. The sampling sites for each lake are arranged left-to-right in the order of increasing drainage area. Site names followed by an asterisk $\left({ }^{*}\right)$ and in red font are classified as mine-impacted sites. A diagonal-lined background indicates a reference site (site with no upstream shale-gas development). When applicable, the reporting level has been displayed as a dashed black line across the boxplots and censored values beneath this line have not been shown. 

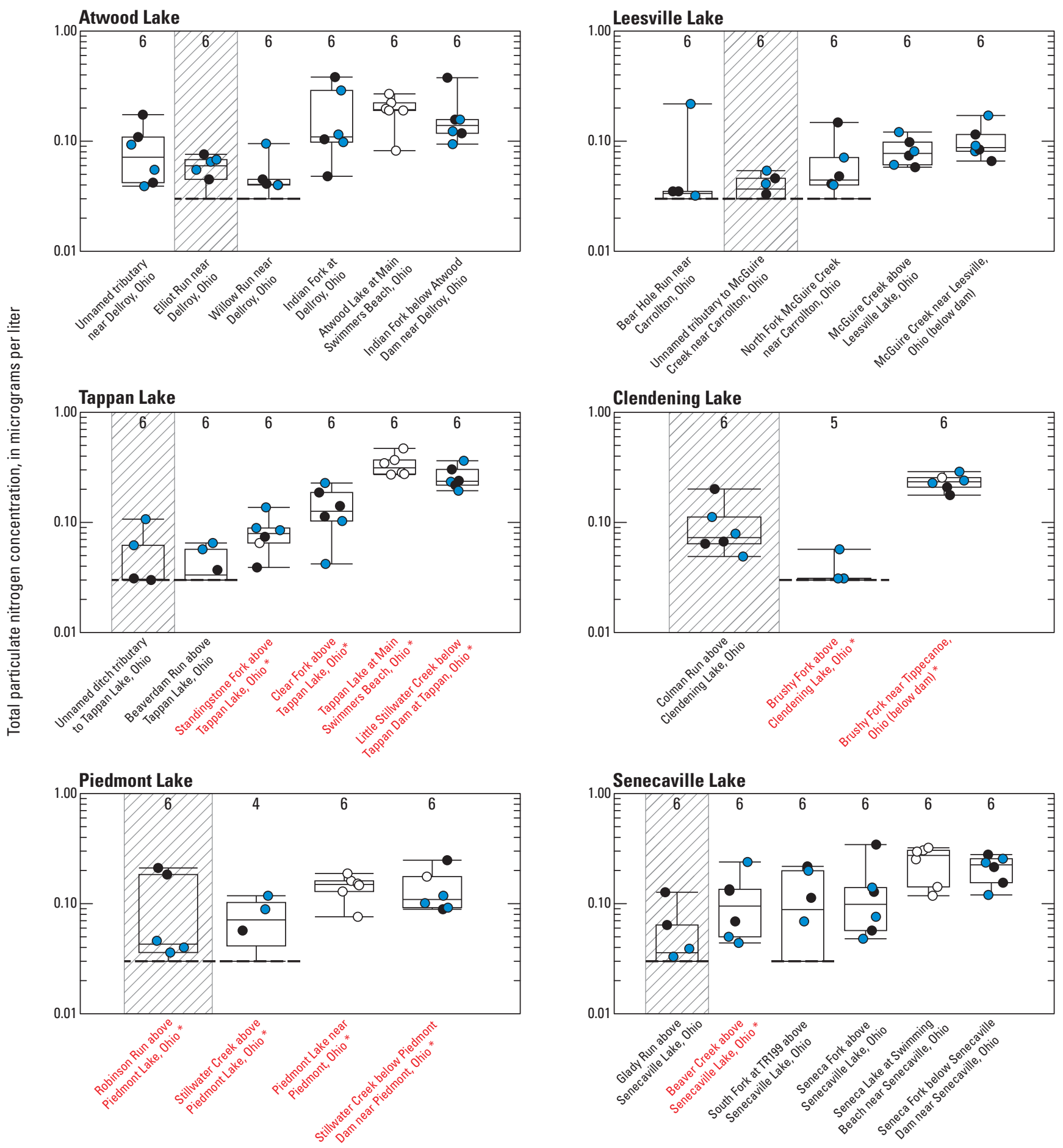

Sites ordered, left to right, from smallest to largest drainage area

Figure 2.34. Total particulate nitrogen concentrations at 30 sites in the Muskingum River watershed, Ohio, 2015-16. The sampling sites for each lake are arranged left-to-right in the order of increasing drainage area. Site names followed by an asterisk $\left({ }^{*}\right)$ and in red font are classified as mine-impacted sites. A diagonal-lined background indicates a reference site (site with no upstream shale-gas development). When applicable, the reporting level has been displayed as a dashed black line across the boxplots and censored values beneath this line have not been shown. 

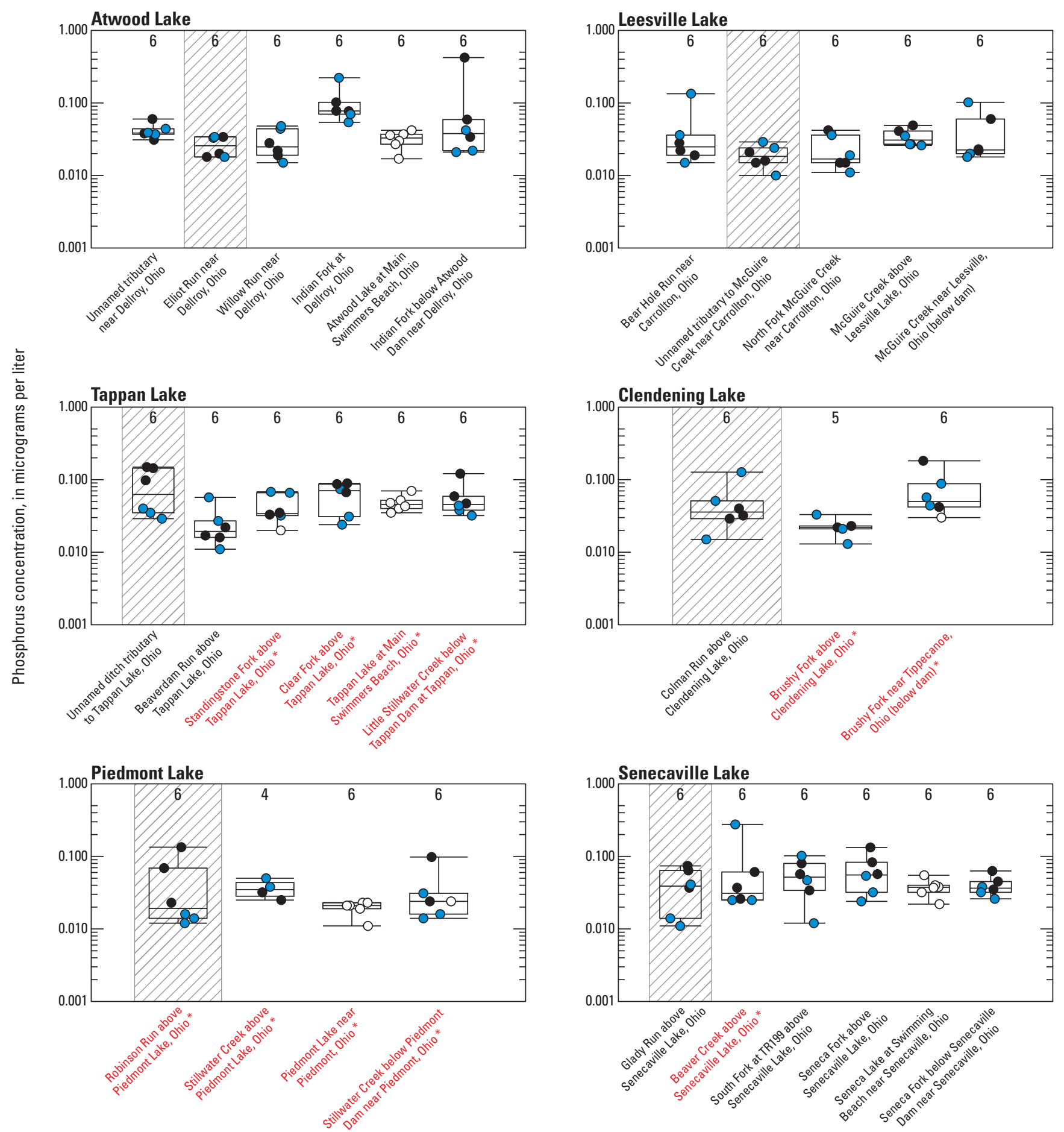

Sites ordered, left to right, from smallest to largest drainage area

Figure 2.35. Phosphorus concentrations at 30 sites in the Muskingum River watershed, Ohio, 2015-16. The sampling sites for each lake are arranged left-to-right in the order of increasing drainage area. Site names followed by an asterisk $\left({ }^{*}\right)$ and in red font are classified as mine-impacted sites. A diagonal-lined background indicates a reference site (site with no upstream shale-gas development). When applicable, the reporting level has been displayed as a dashed black line across the boxplots and censored values beneath this line have not been shown. 

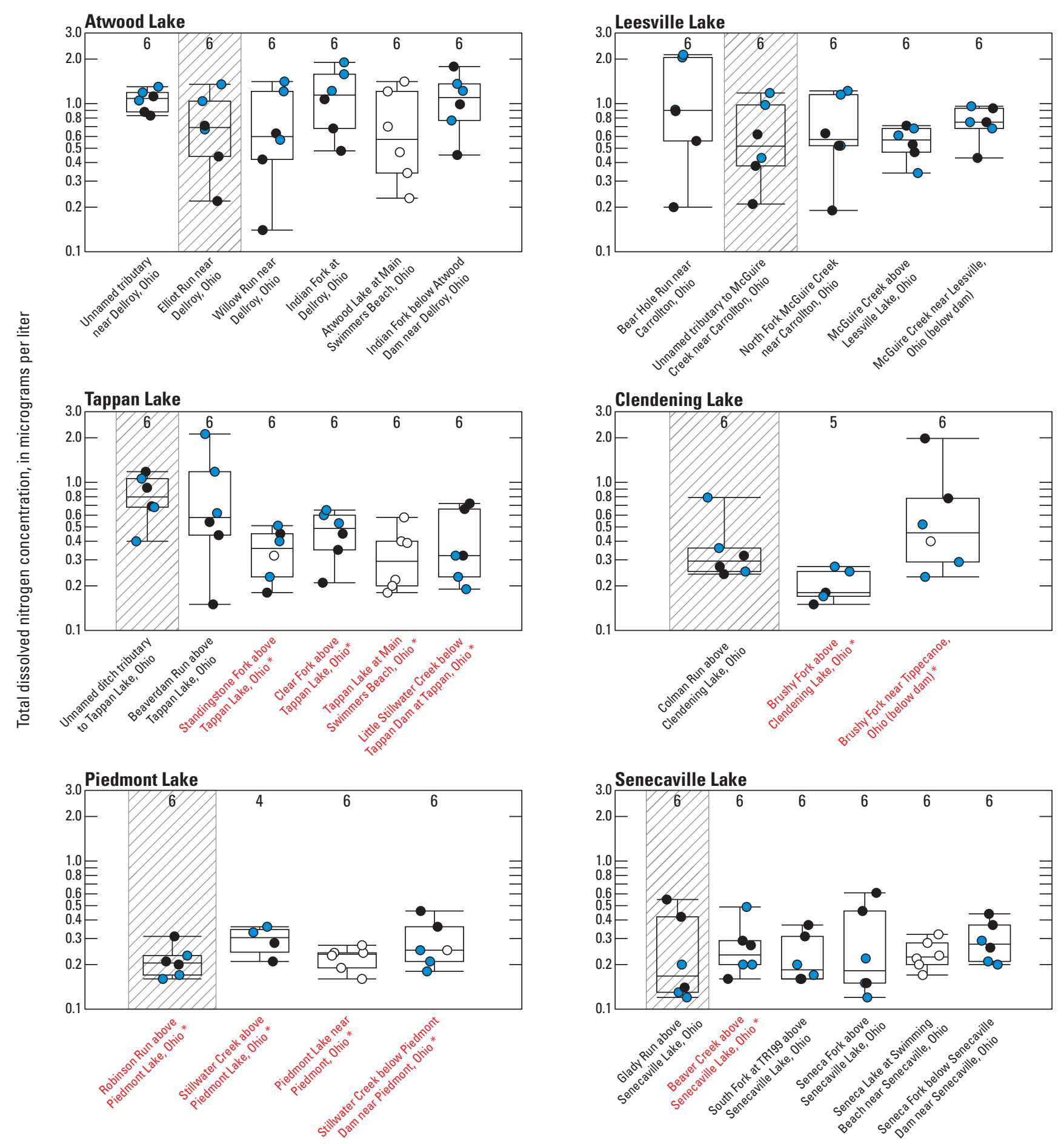

Sites ordered, left to right, from smallest to largest drainage area

Figure 2.36. Total dissolved nitrogen concentrations at 30 sites in the Muskingum River watershed, Ohio, 2015-16. The sampling sites for each lake are arranged left-to-right in the order of increasing drainage area. Site names followed by an asterisk $\left({ }^{*}\right)$ and in red font are classified as mine-impacted sites. A diagonal-lined background indicates a reference site (site with no upstream shale-gas development). When applicable, the reporting level has been displayed as a dashed black line across the boxplots and censored values beneath this line have not been shown. 

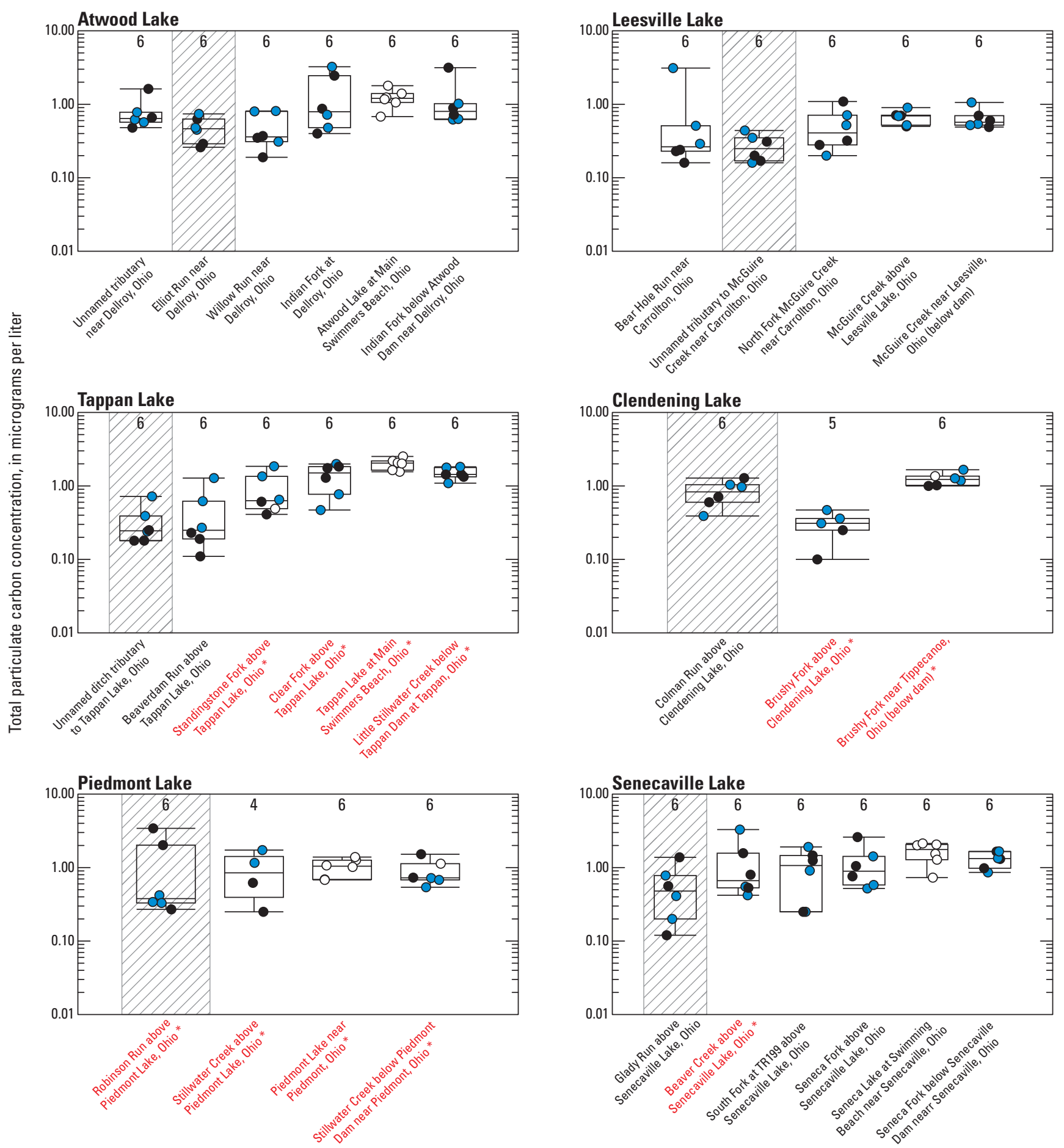

Sites ordered, left to right, from smallest to largest drainage area

Figure 2.37. Total particulate carbon concentrations at 30 sites in the Muskingum River watershed, 0hio, 2015-16. The sampling sites for each lake are arranged left-to-right in the order of increasing drainage area. Site names followed by an asterisk $\left({ }^{*}\right)$ and in red font are classified as mine-impacted sites. A diagonal-lined background indicates a reference site (site with no upstream shale-gas development). When applicable, the reporting level has been displayed as a dashed black line across the boxplots and censored values beneath this line have not been shown. 

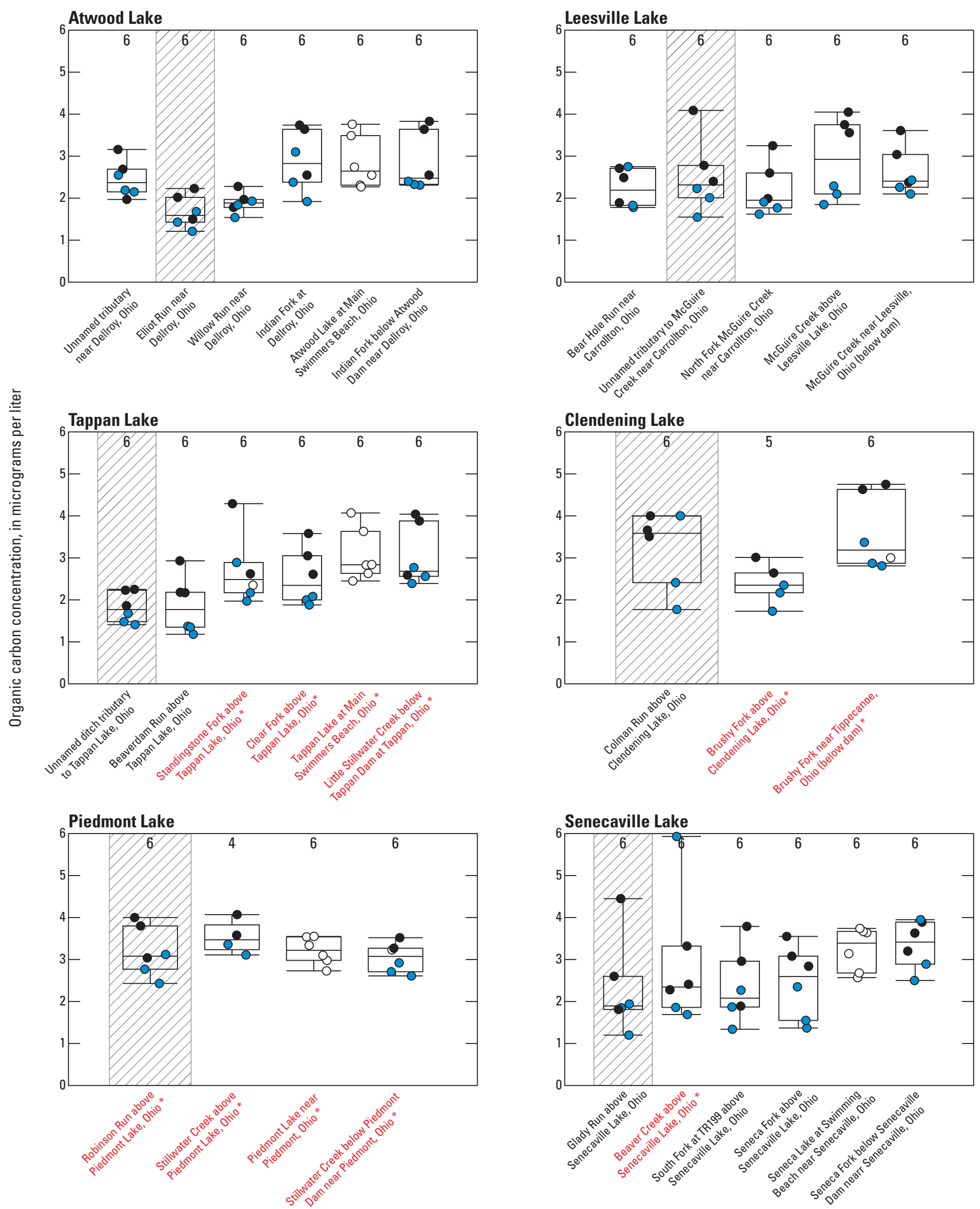

Sites ordered, left to right, from smallest to largest drainage area

Figure 2.38. Organic carbon concentrations at 30 sites in the Muskingum River watershed, Ohio, 2015-16. The sampling sites for each lake are arranged left-to-right in the order of increasing drainage area. Site names followed by an asterisk $\left({ }^{*}\right)$ and in red font are classified as mine-impacted sites. A diagonal-lined background indicates a reference site (site with no upstream shale-gas development). When applicable, the reporting level has been displayed as a dashed black line across the boxplots and censored values beneath this line have not been shown. 

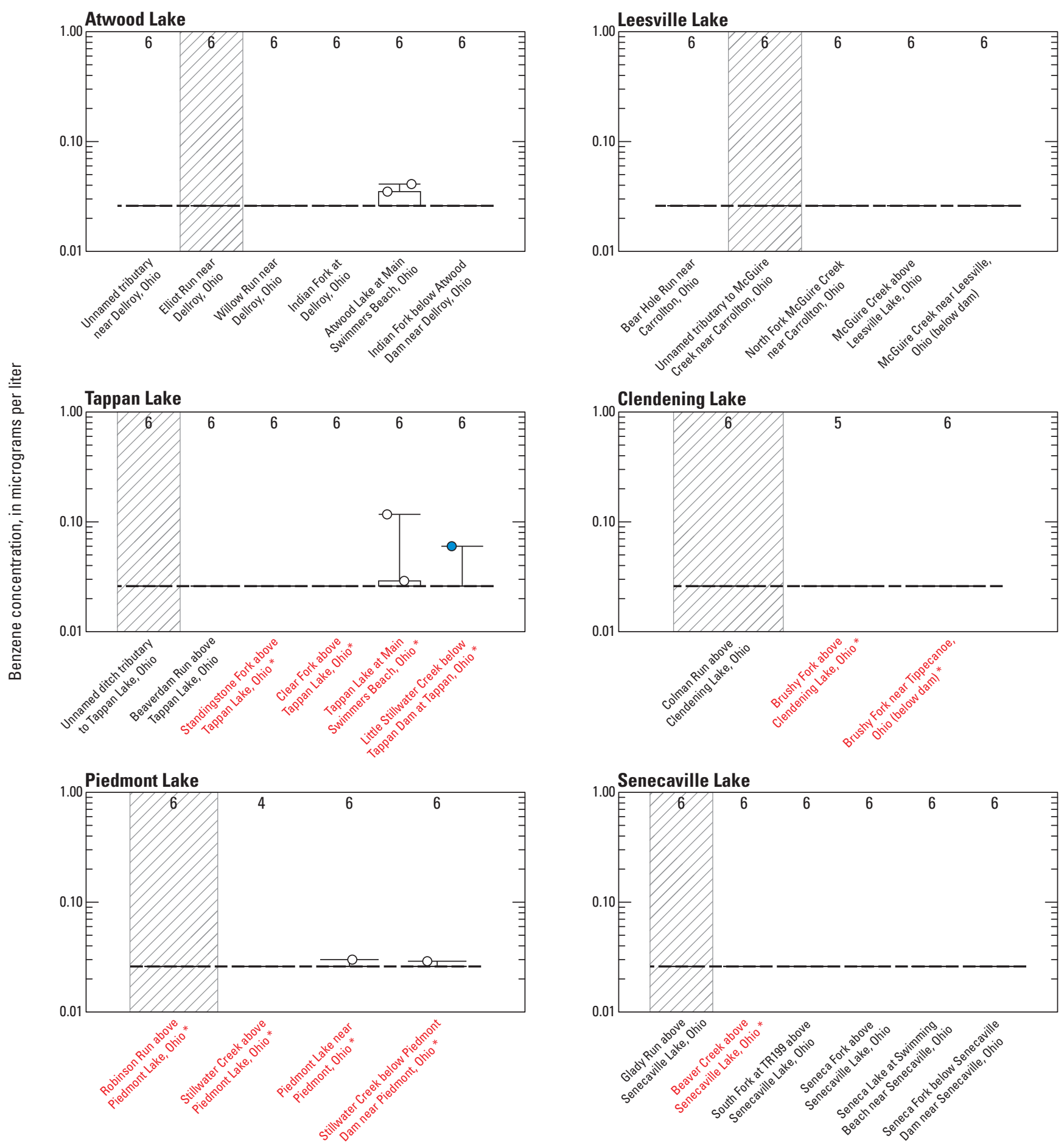

Sites ordered, left to right, from smallest to largest drainage area

Figure 2.39. Benzene concentrations at 30 sites in the Muskingum River watershed, 0hio, 2015-16. The sampling sites for each lake are arranged left-to-right in the order of increasing drainage area. Site names followed by an asterisk $\left({ }^{*}\right)$ and in red font are classified as mine-impacted sites. A diagonal-lined background indicates a reference site (site with no upstream shale-gas development). When applicable, the reporting level has been displayed as a dashed black line across the boxplots and censored values beneath this line have not been shown. 

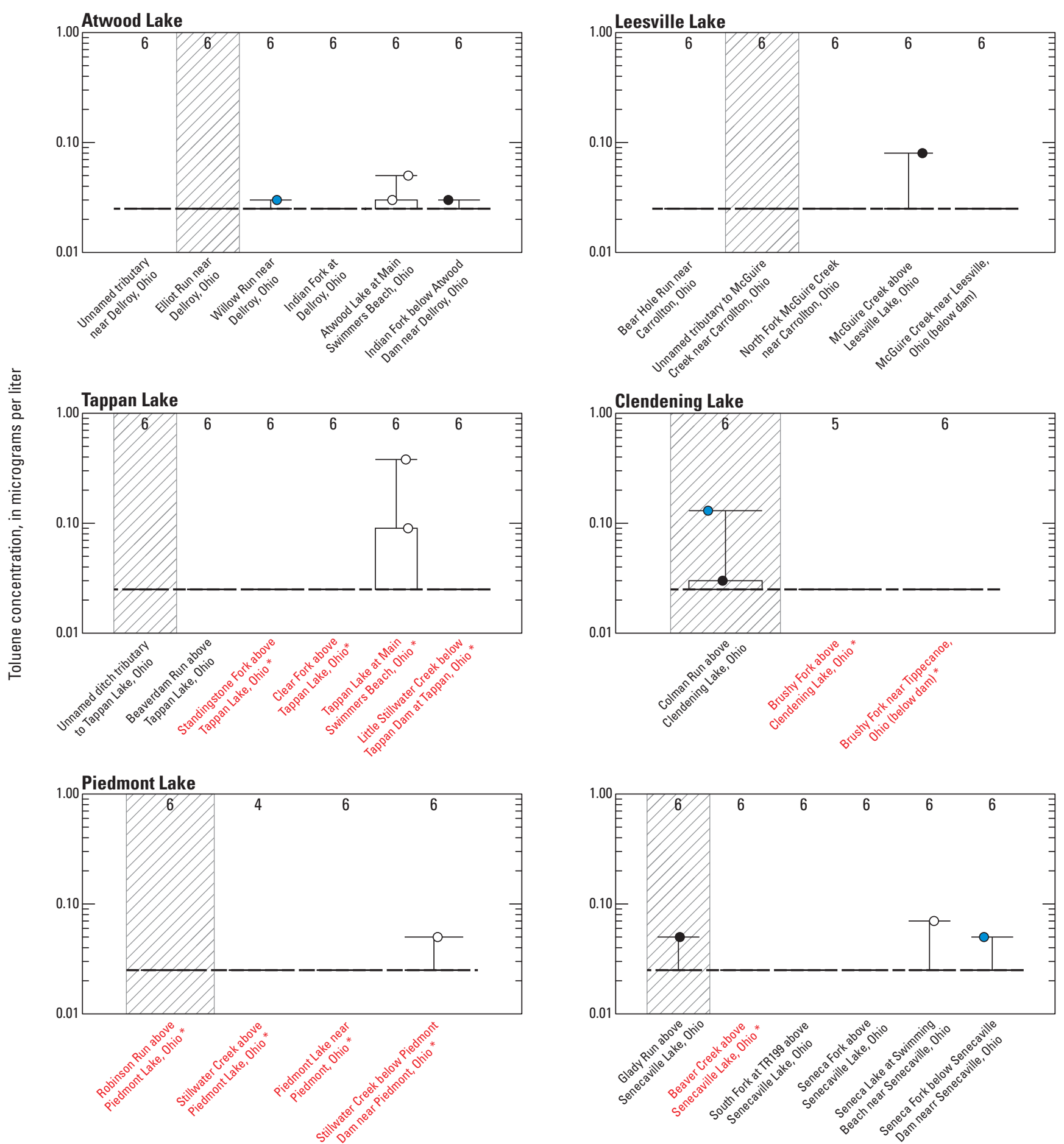

Sites ordered, left to right, from smallest to largest drainage area

Figure 2.40. Toluene concentrations at 30 sites in the Muskingum River watershed, Ohio, 2015-16. The sampling sites for each lake are arranged left-to-right in the order of increasing drainage area. Site names followed by an asterisk (*) and in red font are classified as mine-impacted sites. A diagonal-lined background indicates a reference site (site with no upstream shale-gas development). When applicable, the reporting level has been displayed as a dashed black line across the boxplots and censored values beneath this line have not been shown. 


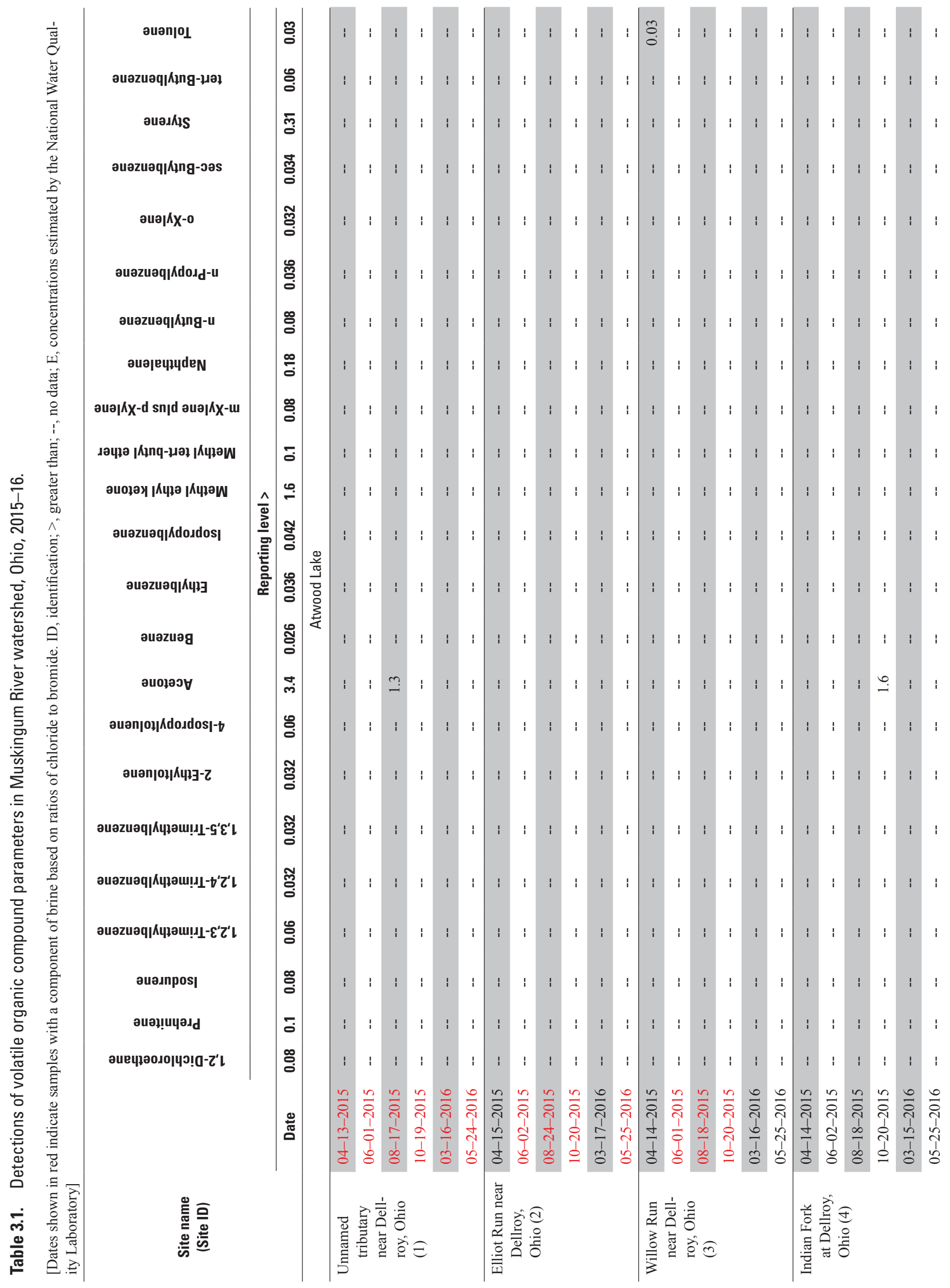




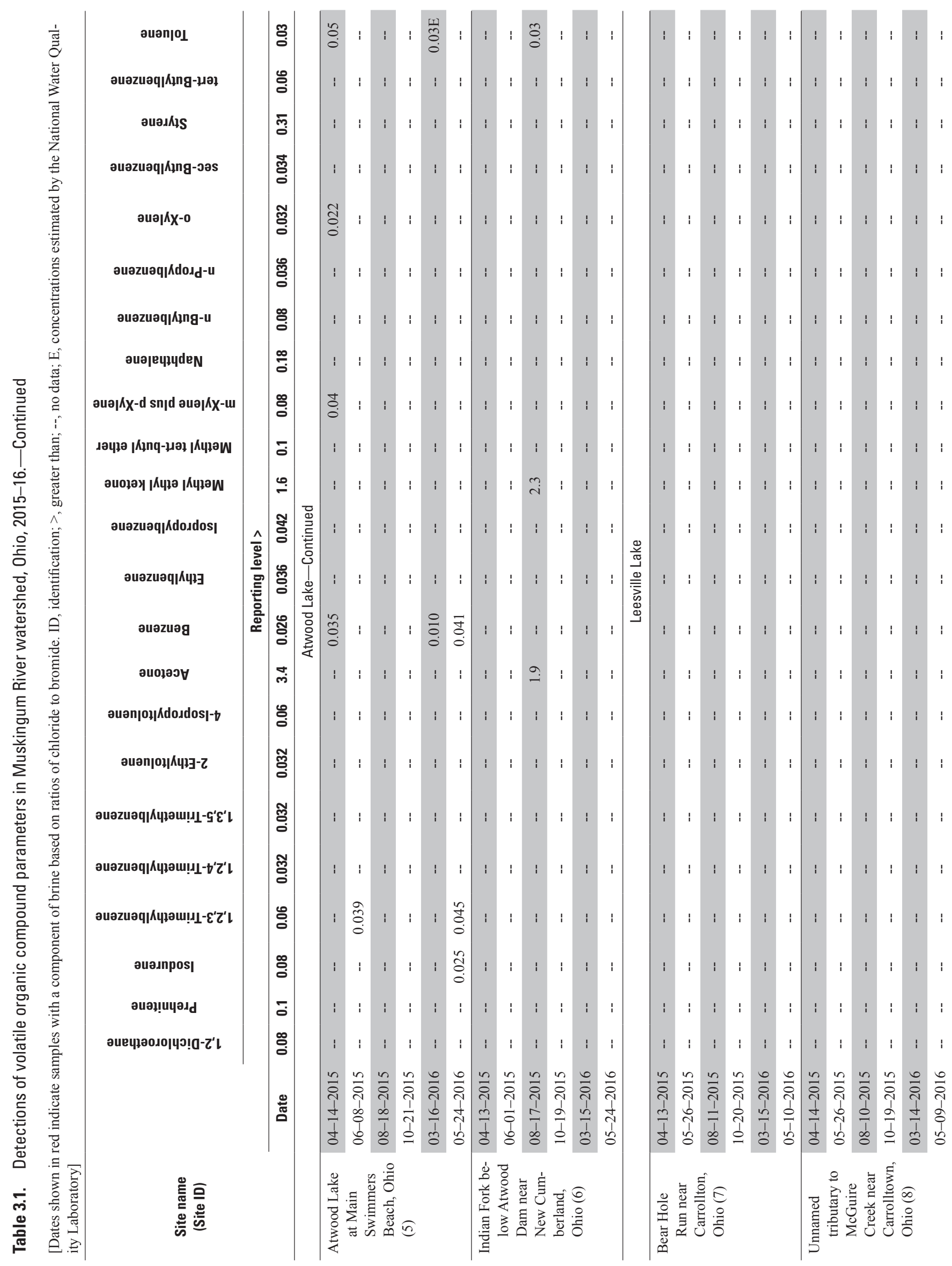




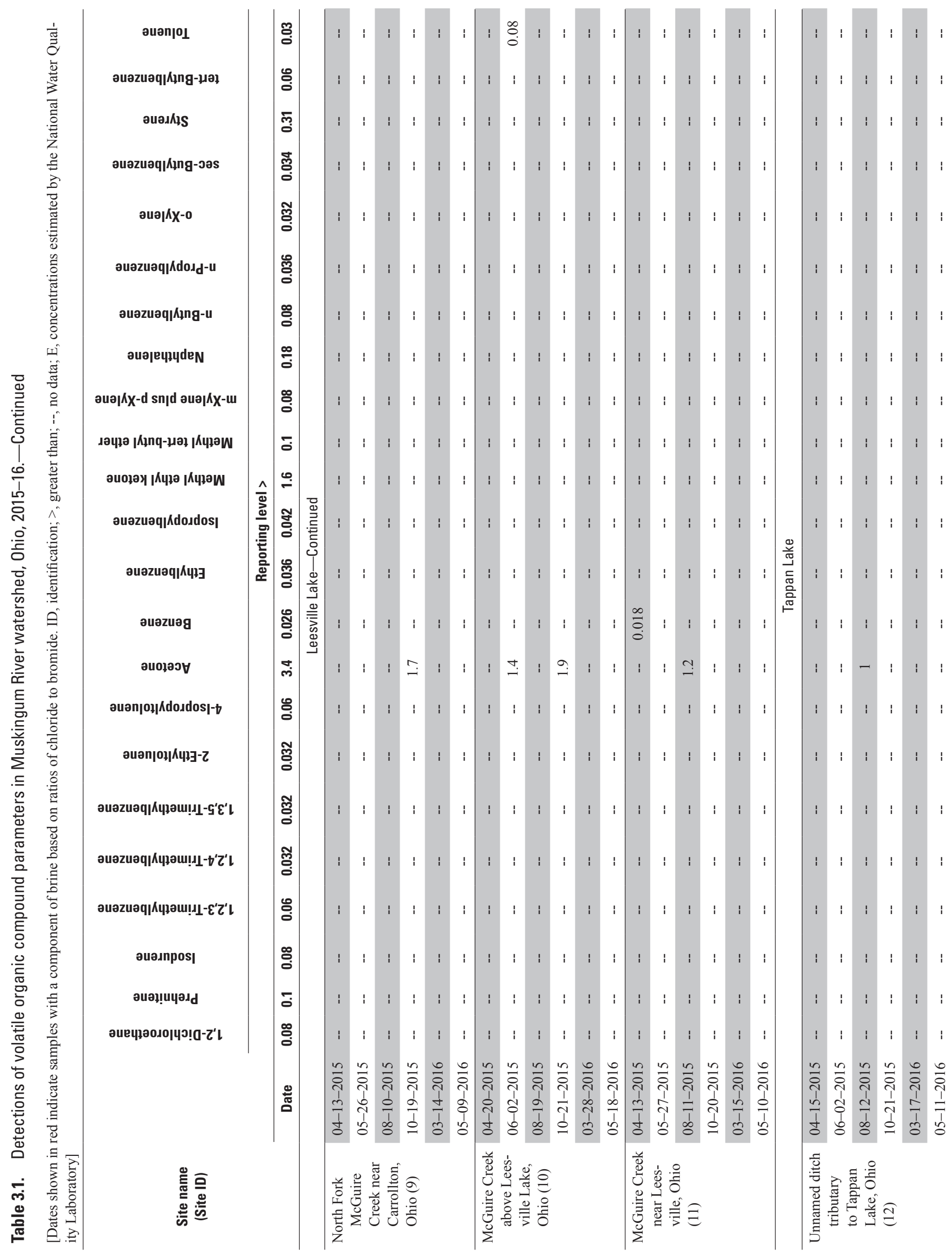




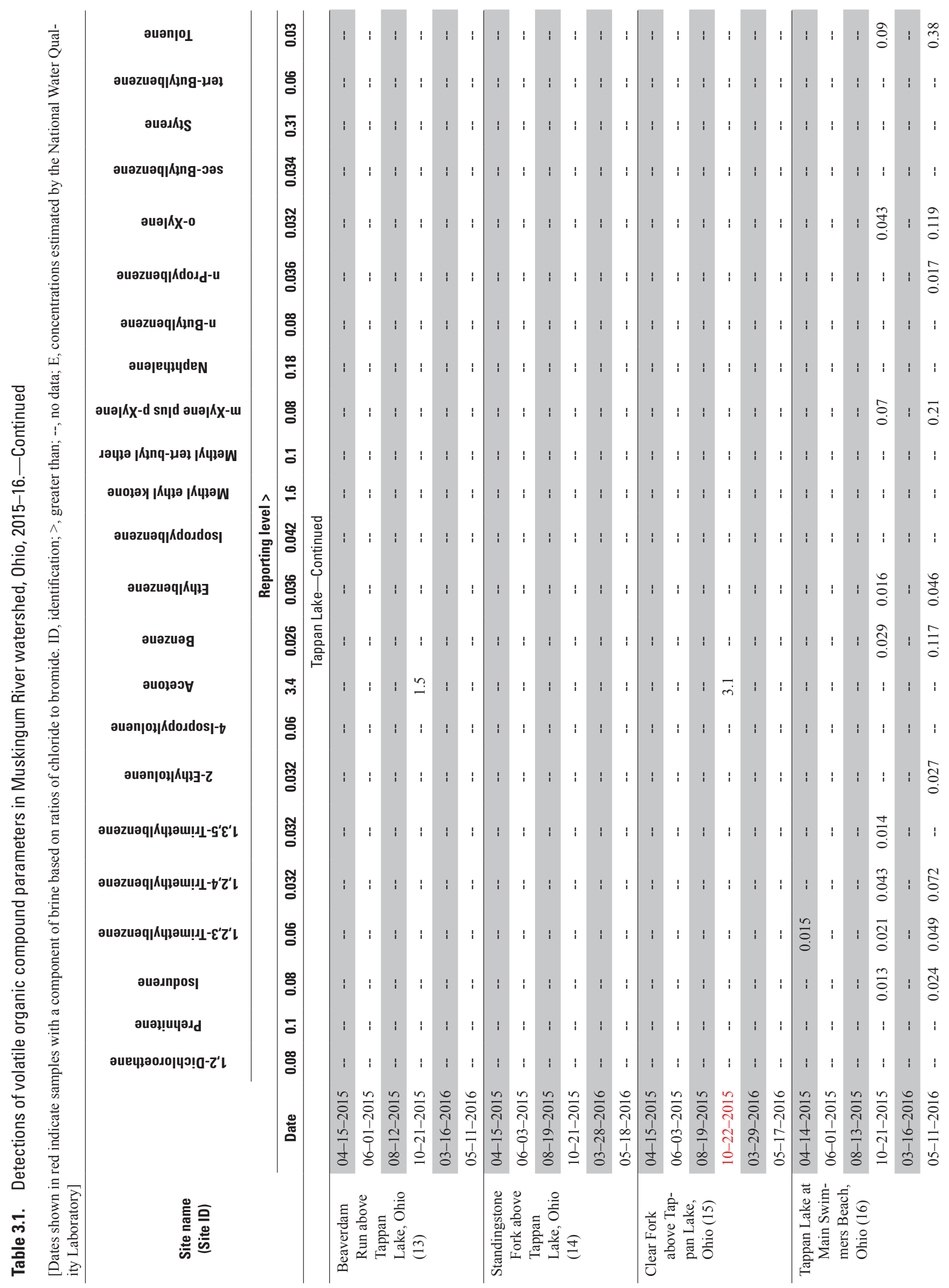




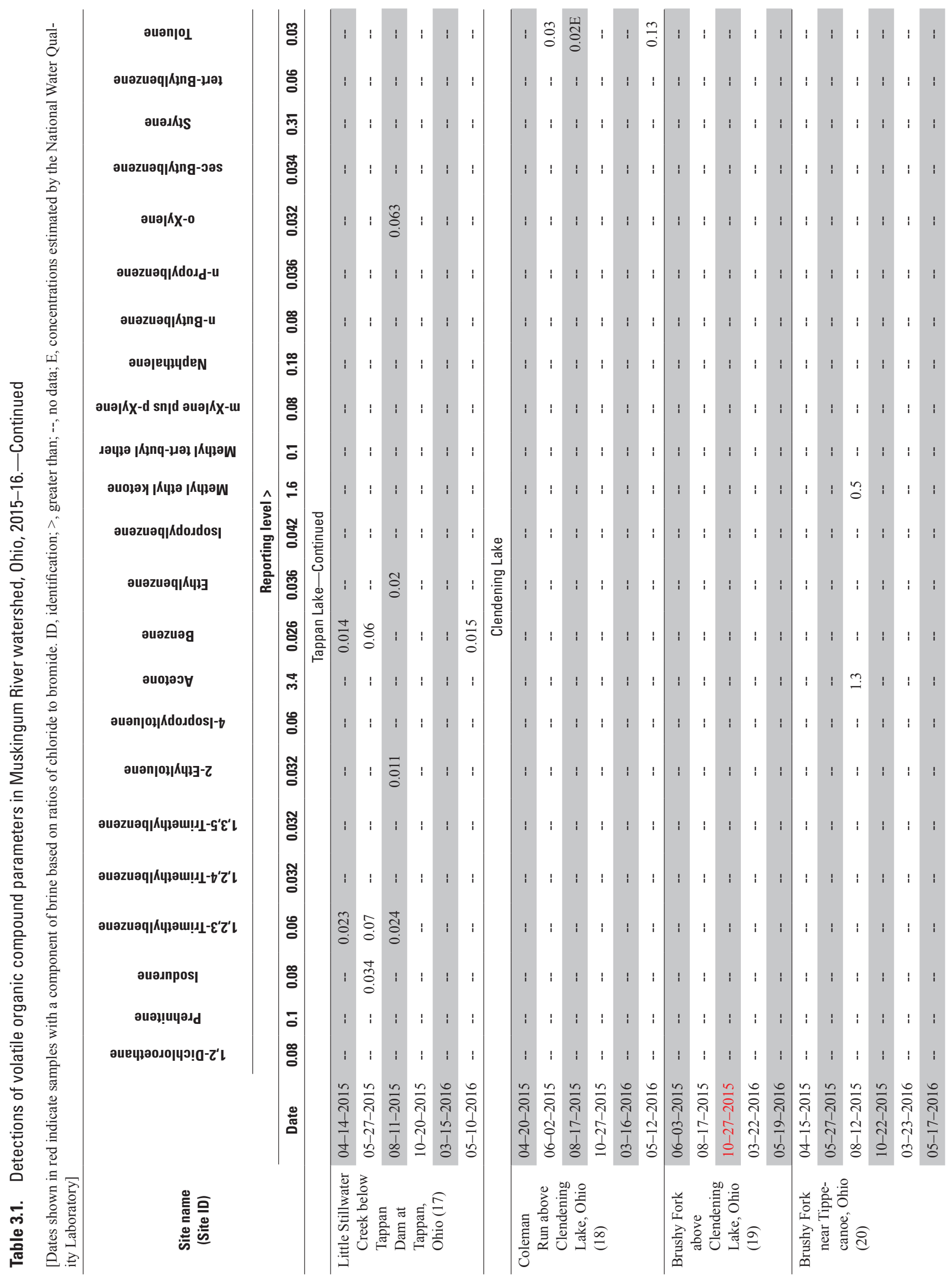




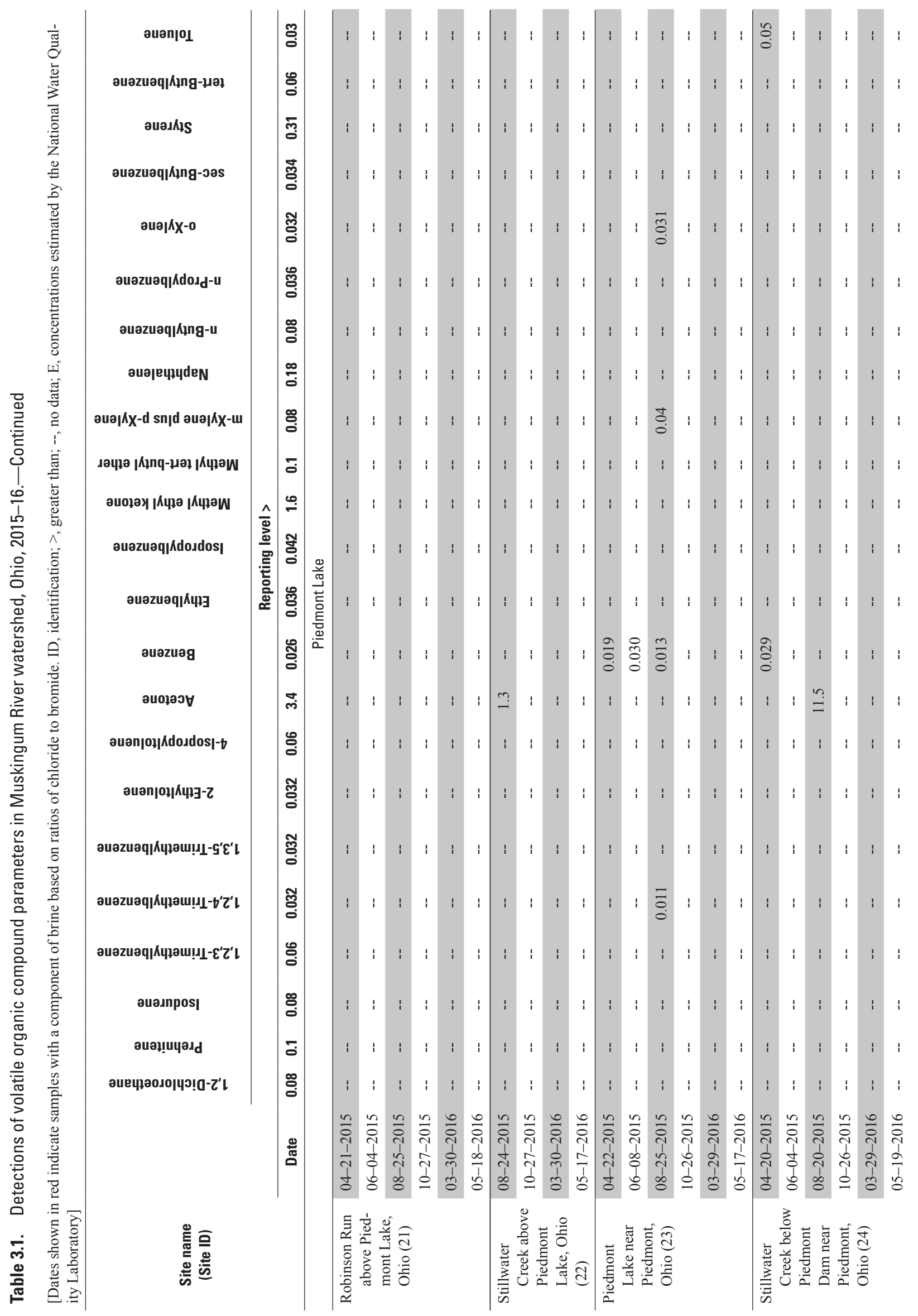




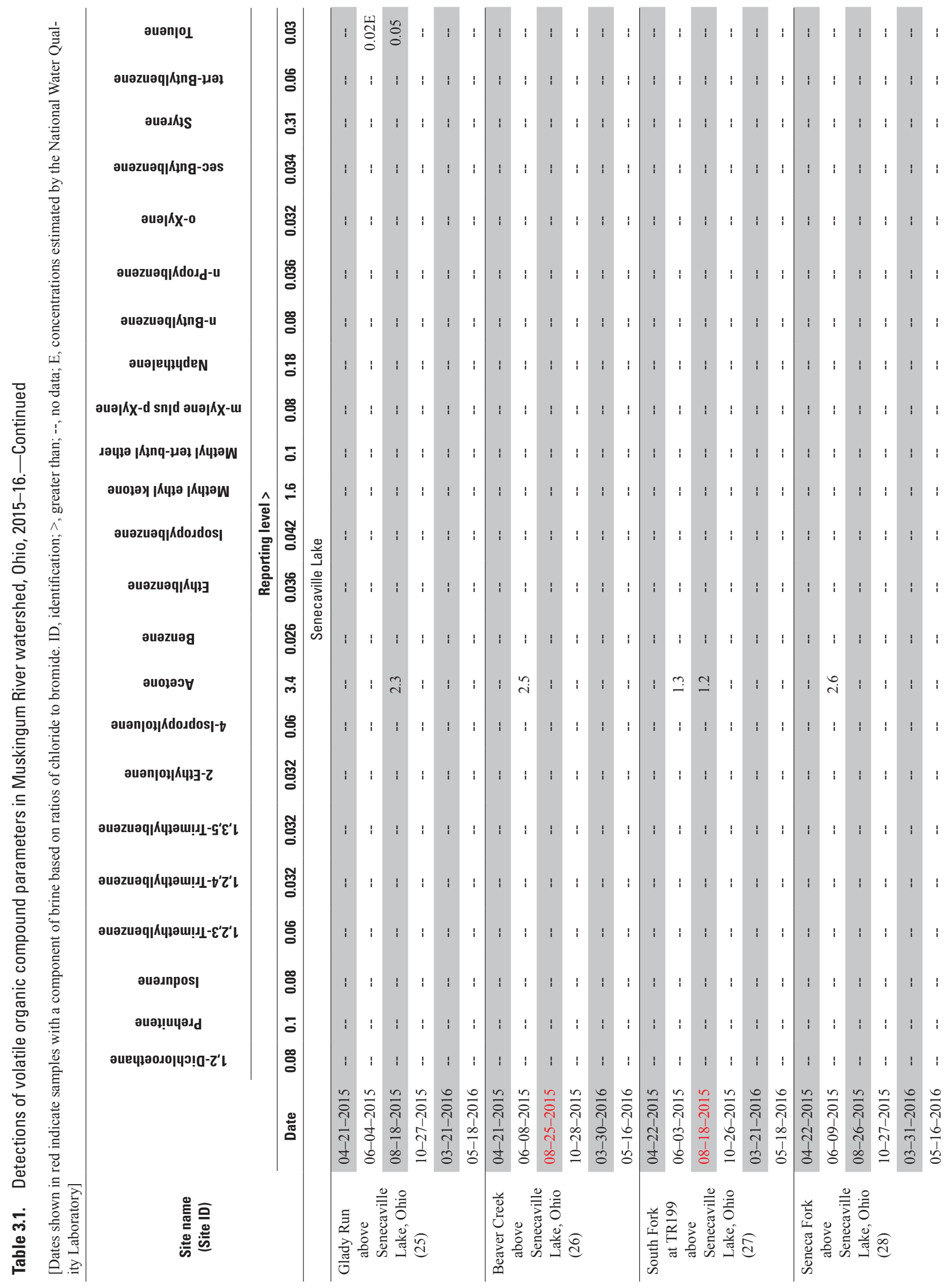




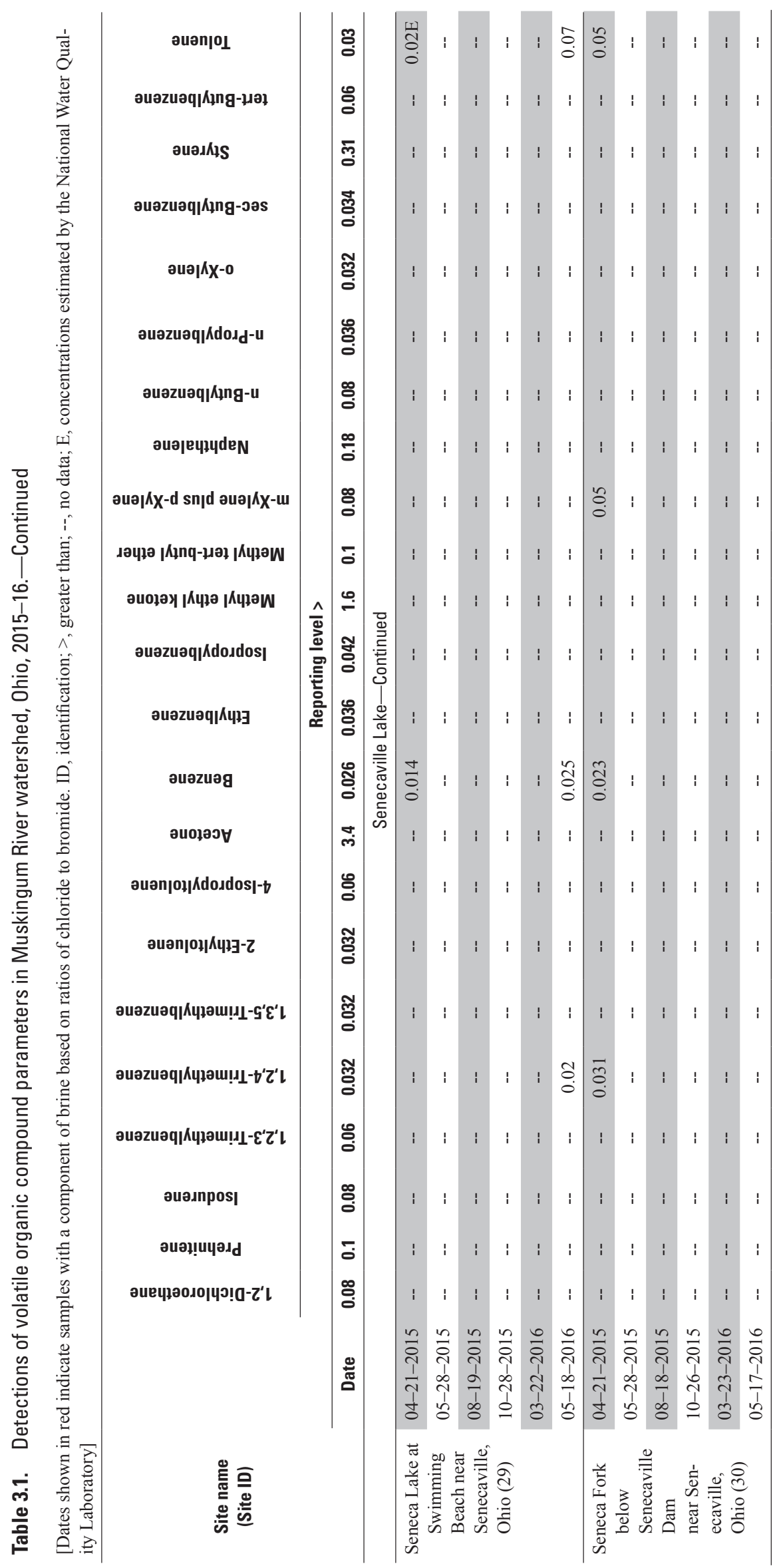



For additional information about this publication, contact:

Director, Ohio-Kentucky-Indiana Water Science Center 6460 Busch Blvd

Suite 100

Columbus, $\mathrm{OH}$ 43229-1737

or visit https://www.usgs.gov/centers/oki-water

Publishing support provided by the

Madison and Pembroke Publishing Service Centers 
